\title{
HIPERICINA, PHOTODITHAZINE E PHOTOGEM: UM ESTUDO COMPARATIVO DA ATIVIDADE FOTODINÂMICA
}

Claudia Bernal

Tese apresentada ao Instituto de Química de São Carlos, da Universidade de São Paulo para obtenção do título de Doutor em Ciências (Química Analítica)

Orientadora: Profa. Dra. Janice Rodrigues Perussi

São Carlos 
Este exemplar foi revisado e alterado em relação à versão original, sob a exclusiva responsabilidade do autor.

São Carlos, 15/06/2011

Claudia Bernal 


\section{AGRADECIMENTOS}

À Profa. Dra. Janice Rodrigues Perussi, pela oportunidade e incentivo de realizar este trabalho, pela paciência, orientação e amizade.

Ao Prof. Dr. Vanderlei S. Bagnato por ceder os fotossensibilizadores Photogem e Photodithazine e pelo desenvolvimento dos Biotables.

Ao Prof. Dr. Otaciro Rangel Nascimento por permitir e orientar a realização dos experimentos de RPE.

Ao Prof. Dr. Anderson O. Ribeiro e seu grupo pela síntese da Hipericina bem como a aos Prof. Dr. Osvaldo A. Serra e Yassuko lamamoto da FFCLRP - USP e ao Prof. Dr. Kleber T. Oliveira da UFSCar que participaram dos trabalhos.

Ao Prof. Dr. Hidetake Imasato sempre bem humorado e atencioso.

À FAPESP pelo apoio financeiro ao projeto via o Centro de Pesquisas, Inovação e Difusão em Ótica e Fotônica (CEPOF) sob a coordenação do Prof. Dr. Vanderlei S. Bagnato.

Ao Instituto de Química e Física Molecular, todos os professores e funcionários que contribuíram para minha formação e para a realização desse trabalho.

A minha família, à minha mãe e irmãos, por todo o carinho e incentivo em várias etapas da minha vida, sempre querendo participar perguntando e pelo orgulho que sentem de mim. Ao meu pai (in memorium) o meu maior admirador.

À todos os meus amigos do Instituto de Química, em especial a Alessandra Poli, pelos inúmeros momentos de descontração em todos esses anos de convivência. 
Às minhas amigas e colegas de trabalho Claudia Nascimento, Veroneide e Gislei por tornarem os dias de trabalho mais alegres.

Aos amigos conquistados recentemente Joyce, Adriel, Wanessa, Lucas, Kelly, Cíntia, Pedro e Ana Paula.

À minha amiga Tania T. Tominaga pela ajuda inestimável em vários momentos da execução desse trabalho, especialmente nas medidas de RPE.

À Ana Paula Guimarães (Aninha) pela ajuda em inúmeros ensaios com as células.

À EMBRARAD pela irradiação com raios- $\gamma$ do material para cultura celular.

Enfim, a todos que de uma forma ou de outra contribuíram para a realização deste trabalho. 
Dedico esta tese ao meu marido Fernando, meu melhor amigo, admirador incansável, meu eterno amor. 


\section{RESUMO}

A Terapia Fotodinâmica (TFP) é uma técnica para tratamento de câncer que usa um fotossensibilizador (FS) na presença de luz e oxigênio gerando espécies altamente reativas de oxigênio que levam as células tumorais à morte.

Neste trabalho foi realizado um estudo comparativo com três FSs: Photogem ${ }^{\circledR}$ (PG), um derivado de hematoporfirina que está sendo usado em TFD no Brasil; Photodithazine ${ }^{\circledR}(\mathrm{PZ})$, um derivado hidrossolúvel de mono-L-aspartil clorina, que está na fase clínica para aprovação e Hipericina (HY), um pigmento fotoativo encontrado na planta Hypericum perforatum e usado na medicina popular que está sendo considerado como um promissor agente fotodinâmico para o tratamento de tumores. Este estudo utilizou uma Hipericina sintetizada no Brasil e diversos parâmetros para comparar os três FSs: a concentração inibitória média $\left(\mathrm{IC}_{50}\right)$ em linhagens celulares; a constante de velocidade de fotoxidação da albumina de soro bovino na presença dos FSs e luz determinada pelo decréscimo na fluorescência da BSA em $340 \mathrm{~nm}$; a fotoxidação do ácido úrico acompanhada pelo decréscimo da banda característica do ácido úrico em 290 nm após irradiação na presença dos FSs como uma estimativa indireta do rendimento quântico de formação de oxigênio singlete $(\Delta \Phi)$; o rendimento quântico de fluorescência utilizando rodamina $B$ como padrão; a acumulação dos FSs em células em função do tempo de incubação e a estimativa da quantidade de radicais livres formados após irradiação através da técnica de captura de spins. Todos os resultados obtidos evidenciam uma maior eficiência fotodinâmica da HY seguida pelo PZ e depois por Photogem e, portanto sugerem a Hipericina como o FS de maior potencial para utilização em Terapia Fotodinâmica. 


\section{ABSTRACT}

Photodynamic Therapy (PDT) is a technique for the cancer treatment that uses a photosensitizer (FS) in the presence of light and oxygen which combined are able to generate highly reactive oxygen species that lead to tumor cells death.

In this investigation, a comparative study with three FSs: Photogem $®(P G)$, a hematoporphyrin derivative being used in PDT in Brazil; Photodithazine ${ }^{\circledR}(\mathrm{PZ})$, a soluble derivative of mono-L-aspartyl chlorin, which is in clinical phase for approval and Hypericin (HY), a photoactive pigment found in the plant Hypericum perforatum and used in popular medicine that is being considered as a promising agent for photodynamic treatment of tumors. The present study used a Hypericin synthesized in Brazil and several parameters to compare these three FSs: the mean inhibitory concentration $\left(\mathrm{IC}_{50}\right)$ in cell lines; the rate constant for the photooxidation of bovine serum albumin in the presence of light and the FSs determined by the decrease in the fluorescence of BSA at $340 \mathrm{~nm}$; the photooxidation of uric acid assessed by the decrease of the characteristic band of uric acid at $290 \mathrm{~nm}$ after irradiation in the presence of the FSs as an indirect estimate of the quantum yield of formation of singlet oxygen $(\Delta \Phi)$; the quantum yield of fluorescence using rhodamine $\mathrm{B}$ as a standard; the accumulation of FSs in cells as a function of the incubation time, and the estimative of the produced free radicals after irradiation by the technique of spin trapping. All the results show a higher photodynamic efficiency of HY followed by PZ and then by Photogem suggesting Hypericin as the FS with the greatest potential for use in Photodynamic Therapy. 


\section{ÍNDICE DE FIGURAS}

Figura 1 - Esquema de aplicação da TFD: a) Paciente com tumor recebendo FS intravenoso; b) FS localizado no tumor após certo tempo; c) tumor sendo irradiado por luz visível de comprimento de onda adequado; d) desaparecimento do tumor 26

Figura 2 - Diagrama de Jablonski: ilustração gráfica dos mecanismos fotoquímicos e fotofísicos em TFD 29

Figura 3 - Representação esquemática de um corte de tecido humano e o percentual de penetração da luz de diferentes comprimentos de onda

Figura 4 - Fórmula estrutural de uma porfina 33

Figura 5 - Estrutura monomérica do Photogem ............................................. 36

Figura 6 - Fórmula estrutural do Photodithazine ………............................... 38

Figura 7 - Fórmula estrutural da Hipericina ……............................................ 40

Figura 8 - a) Fórmula estrutural do 5,5-dimetil-1-pirroline-N-oxide e b) espectro do aduto $\mathrm{DMPO} / \mathrm{OH}$ com constante de acoplamento hiperfino de $\mathrm{a}_{\mathrm{N}}=$ $a_{H}=14,9 \mathrm{G}$ 54

Figura 9 - Fontes de luz utilizadas: a) LED com emissão em $630 \pm 10 \mathrm{~nm}$ e b) LED com emissão em $590 \pm 11 \mathrm{~nm}$ 58

Figura 10 - Espectros de absorção ótica da $\mathrm{HY} 15 \mu \mathrm{g} \mathrm{mL} \mathrm{L}^{-1}$, a) em PBS, $\mathrm{pH}=7,4, \mathrm{~b}$ ) em DMSO

Figura 11 - Espectro de absorção ótica do PG $15 \mu \mathrm{g} \mathrm{mL} \mathrm{L}^{-1}$, em PBS, pH = 7,4 f.. 73

Figura 12 - Espectro de absorção ótica do PZ $15 \mu \mathrm{g} \mathrm{mL}^{-1}$, em PBS, $\mathrm{pH}=7,4 \ldots . .74$ 
Figura 13 - a) Espectros de absorção ótica da HY em PBS, pH 7,4 em várias concentrações; b) Absorbância da Hipericina em PBS na banda em 606 nm em função da sua concentração 75

Figura 14 - a) Espectros de absorção ótica do PG em PBS, pH 7,4 em várias concentrações; b) Absorbância do Photogem em PBS na banda em 506 nm em função da sua concentração 76

Figura 15 - a) Espectros de absorção ótica do PZ em PBS, pH 7,4 em várias concentrações; b) Absorbância do Photodithazine em PBS na banda em 656 nm em função da sua concentração 76

Figura 16 - a) Espectro de absorção ótica da HY $15 \mu \mathrm{g} \mathrm{mL}^{-1}$ em DMSO no período de 4 meses; b) Absorbância em $598 \mathrm{~nm}$ em função do tempo de armazenamento

Figura 17 - a) Espectro de absorção ótica do PG $15 \mu \mathrm{gL}^{-1}$ em PBS pH 7,4, no período de 6 meses; b) Absorbância em $367 \mathrm{~nm}$ em função do tempo de armazenamento 78

Figura 18 - a) Espectro de absorção ótica do PZ $15 \mu \mathrm{gL}^{-1}$ em PBS pH 7,4, no período de 6 meses; b) Absorbância em $596 \mathrm{~nm}$ em função do tempo de armazenamento

Figura 19 - Espectros de absorção ótica da HY $50 \mu \mathrm{g} \mathrm{mL} \mathrm{L}^{-1}$ em PBS irradiada com LED vermelho por até $122 \mathrm{~min}$ 80

Figura 20 - Valores de absorbância da HY $50 \mu \mathrm{gL}^{-1}$ em PBS irradiada com LED vermelho por 122 min. a) Máximo de absorção em 564 nm; b) Máximo de absorção em $606 \mathrm{~nm}$ 81

Figura 21 - Espectros de absorção ótica do PZ $50 \mu \mathrm{g} \mathrm{mL}{ }^{-1}$ em PBS (pH 7,4) irradiado com LED vermelho $\mathrm{l}=18 \mathrm{~mW} \mathrm{~cm}^{-2}$ por até $60 \mathrm{~min}$ 
Figura 22 - Valores de absorbância do PZ $50 \mu \mathrm{gL}^{-1}$ em PBS $(\mathrm{pH} 7,4)$ irradiado com LED vermelho I= $18 \mathrm{~mW} \mathrm{~cm}^{-2}$ por $60 \mathrm{~min}$ em $656 \mathrm{~nm}$

Figura 23 - Espectros de absorção ótica do PG $50 \mu \mathrm{g} \mathrm{mL}{ }^{-1}$ em PBS $(\mathrm{pH} 7,4)$ irradiado com LED vermelho por até $60 \mathrm{~min}$

Figura 24 - Valores de absorbância em 656 nm do PG $50 \mu \mathrm{gL}^{-1}$ em PBS $(\mathrm{pH} 7,4)$ irradiado com LED vermelho $\mathrm{I}=18 \mathrm{~mW} \mathrm{~cm}^{-2}$ por 60 min em $656 \mathrm{~nm}$

Figura 25 - Efeito do tempo de incubação com 1\% de DMSO sobre a proliferação da HEp-2 e da Vero em diferentes tempos de incubação no a) escuro, b) claro, 15 min de irradiação, LED $\Lambda=630 \mathrm{~nm}, \mathrm{l}=18 \mathrm{~mW} \mathrm{~cm}^{-2}$. Os ensaios foram realizados três vezes em sextuplicata 87

Figura 26 - Efeito da dose de luz em 630 nm no $I_{50}$ após duas horas de incubação com HY, PZ e PG, a) linhagem HEp-2 e b) linhagem Vero 94

Figura 27 - Valores de IC 50 para a HY, PG e PZ, nas células HEp-2 e Vero, obtidos após 2 horas de incubação e $8 \mathrm{~min}$ de irradiação no LED vermelho, $\mathrm{D}=8,6 \mathrm{~J} \mathrm{~cm}^{-2}$ 100

Figura 28 - Valores de IC 50 para a HY, PG e PZ, nas células HEp-2 e Vero, obtidos após 2 horas de incubação e $27 \mathrm{~min}$ de irradiação no LED amarelo, $\mathrm{D}=16,2 \mathrm{~J} \mathrm{~cm}^{-2}$ 101

Figura 29 - Espectros de emissão de fluorescência obtidos para BSA ( $\Lambda_{\text {exc }}=279 \mathrm{~nm}$ ) devido ao efeito fotodinâmico. Solução de BSA $\left(2 \times 10^{-3} \mathrm{~mol} \mathrm{~L}^{-1}\right)$ preparada em PBS e irradiada com LED $\left(630 \mathrm{~nm}, \mathrm{I}=18 \mathrm{~mW} \mathrm{~cm}{ }^{-2}, \mathrm{t}=60 \mathrm{~min}\right)$ na presença de FS (1 $\left.\quad \mu g \quad \mathrm{~mL}^{-1}\right)$; $\quad$ a) Hipericina, b) Photodithazine, c) Photogem 103 
Figura 30 - Cinética de fotoxidação da BSA ocorrida na presença dos FSs: a) Hipericina; b) Photodithazine e c) Photogem. Solução de BSA BSA $\left(2 \times 10^{-3} \mathrm{~mol} \mathrm{~L}^{-1}\right)$ preparada em PBS e irradiada com LED $(630 \mathrm{~nm}$,

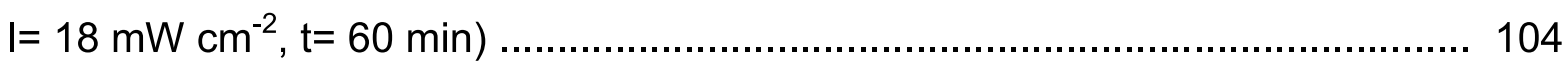

Figura 31 - a) Comparação dos coeficientes angulares (k) obtidos diretamente da relação linear entre In $\left(F / F_{0}\right)$ e o tempo de irradiação. b) Comparação dos valores das constantes de velocidade de fotoxidação da BSA $\left(k_{c}\right)$ obtidas após a correção dos valores de $\mathrm{k}$ pelos valores das absorbâncias dos FSs no comprimento de onda de irradiação $(\lambda=630 \mathrm{~nm})$ 105

Figura 32 - Espectro de absorção ótica do ácido úrico $10 \mu \mathrm{gL}^{-1} \mathrm{em} \mathrm{SDS} \mathrm{2 \% .} 110$ Figura 33 - Variação espectral da mistura Photodithazine $5 \mu \mathrm{g} \mathrm{mL}{ }^{-1}$ e ácido úrico $10 \mu \mathrm{g} \mathrm{mL}^{-1}$ preparada em SDS $2 \%$, irradiada com LED $\left(\Lambda=630 \mathrm{~nm}, \mathrm{l}=18 \mathrm{~mW} \mathrm{~cm}^{-2}\right.$, $\mathrm{t}=20 \mathrm{~min})$

Figura 34 - Variação da absorbância e função do tempo de irradiação em segundos, em a) do ácido úrico em $290 \mathrm{~nm}$ e b) do Photodithazine em $404 \mathrm{~nm}$.. 111 Figura 35 - Espectros de absorção ótica antes e após irradiação com LED (630 nm, $\mathrm{I}=18 \mathrm{~mW} \mathrm{~cm}^{-2}, \mathrm{t}=300 \mathrm{~s}$ ) de uma mistura de AU $10 \mu \mathrm{gL}^{-1}$ e FS $5 \mu \mathrm{gL}^{-1}$ em SDS $2 \%$. A linha preta (-) indica o espectro obtido antes da irradiação e a linha vermelha $(-)$ indica o espectro obtido após 0 tempo de irradiação 113

Figura 36 - Curva padrão da absorbância em 750 nm em função da concentração de BSA. As médias de absorbância foram obtidas de dois ensaios realizados em triplicata 116 
Figura 37 - a) Espectros de emissão de soluções de HY em SDS 2\% e diferentes concentrações. b) Curva analítica para a HY obtida a partir das intensidades de fluorescência em $597 \mathrm{~nm}$ com excitação em $552 \mathrm{~nm}$ da HY em SDS 2\% em diferentes concentrações. Experimentos foram realizados em triplicata

Figura 38 - a) Espectros de emissão de diferentes concentrações de soluções de PZ em $2 \%$ de SDS. b) Curva analítica do PZ obtida a partir das intensidades de fluorescência em $673 \mathrm{~nm}$ do PZ em 2\% de SDS com excitação em 504 nm. Os experimentos foram realizados em triplicata 118

Figura 39 - a) Espectros de emissão de PG em SDS 2\% em diferentes concentrações. b) Curva analítica do PG obtida a partir das intensidades de fluorescência em $620 \mathrm{~nm}$ do PG em SDS 2\% com excitação em $395 \mathrm{~nm}$. Os experimentos foram realizados em triplicata 118

Figura 40 - Acumulação de HY em células HEp-2 normalizada pela concentração de proteína em função do tempo de incubação. Cada ponto representa a média de cinco medidas realizadas em triplicata

Figura 41 - IC $\mathrm{C}_{50}$ da HY em função do tempo de incubação, para células HEp-2, irradiada por $4 \mathrm{~min}$, LED $\Lambda=630 \mathrm{~nm}, \mathrm{I}=18 \mathrm{~mW} \mathrm{~cm}^{-2}, \mathrm{D}=4,3 \mathrm{~J} \mathrm{~cm}^{-2}$. Cada ponto corresponde a média de 4 ensaios realizados em sextuplicata 120

Figura 42 - Acumulação de PZ em células HEp-2 normalizada pela concentração de proteína em função do tempo de incubação Cada ponto corresponde a média de 4 ensaios realizados em sextuplicata. Cada ponto representa a média de cinco medidas realizadas em triplicata 121

Figura $43-\mathrm{IC}_{50}$ do PZ em função do tempo de incubação, para células HEp-2, irradiada por $4 \mathrm{~min}$, LED $\Lambda=630 \mathrm{~nm}, \mathrm{I}=18 \mathrm{~mW} \mathrm{~cm}{ }^{-2}, \mathrm{D}=4,3 \mathrm{~J} \mathrm{~cm}^{-2}$. Cada ponto 
corresponde a média de 3 ensaios realizados em sextuplicata

Figura 44 - Acumulação de PG em células HEp-2 normalizada pela concentração de proteína em função do tempo de incubação. Cada ponto representa a média de cinco medidas realizadas em triplicata

Figura 45 - $\mathrm{IC}_{50}$ do PG em função do tempo de incubação, para células HEp-2, irradiada por $4 \mathrm{~min}$, LED $\Lambda=630 \mathrm{~nm}, \mathrm{I}=18 \mathrm{~mW} \mathrm{~cm}^{-2}, \mathrm{D}=4,3 \mathrm{~J} \mathrm{~cm}^{-2}$. Cada ponto corresponde a média de 3 ensaios realizados em sextuplicata 124

Figura 46 - Relação de concentração da Hipericina, Photodithazine e Photogem normalizada pela proteína acumulada em células HEp-2 em função do tempo de incubação 125

Figura 47 - Acumulação de HY em células Vero normalizada pela concentração de proteína em função do tempo de incubação. Cada ponto representa a média de cinco medidas realizadas em triplicata 126

Figura 48 - $\mathrm{IC}_{50}$ da $\mathrm{HY}$ em função do tempo de incubação, para células Vero, irradiada por $4 \mathrm{~min}$, LED $\Lambda=630 \mathrm{~nm}, \mathrm{I}=18 \mathrm{~mW} \mathrm{~cm}^{-2}, \mathrm{D}=4,3 \mathrm{~J} \mathrm{~cm}^{-2}$. Cada ponto corresponde a média de três ensaios realizados em sextuplicata 127

Figura 49 - Acumulação do PZ em células Vero normalizada pela concentração de proteína em função do tempo de incubação. Cada ponto representa a média de cinco medidas realizadas em triplicata

Figura $50-I_{50}$ do $P Z$ em função do tempo de incubação, para células Vero, irradiada por $4 \mathrm{~min}$, LED $\Lambda=630 \mathrm{~nm}, \mathrm{I}=18 \mathrm{~mW} \mathrm{~cm}^{-2}, \mathrm{D}=4,3 \mathrm{~J} \mathrm{~cm}^{-2}$. Cada ponto corresponde a média de 3 ensaios realizados em sextuplicata 129 
Figura 51 - Acumulação do PG em células Vero normalizada pela concentração de proteína em função do tempo de incubação. Cada ponto representa a média de cinco medidas realizadas em triplicata 130

Figura $52-I_{50}$ do $P G$ em função do tempo de incubação, para células Vero, irradiada por $4 \min$, LED $\Lambda=630 \mathrm{~nm}, \mathrm{I}=18 \mathrm{~mW} \mathrm{~cm}^{-2}, \mathrm{D}=4,3 \mathrm{~J} \mathrm{~cm}^{-2}$. Cada ponto corresponde a média de 3 ensaios realizados em sextuplicata 131

Figura 53 - Relação de concentração da Hipericina, Photodithazine e Photogem normalizada pela proteína de células Vero em função do tempo de incubação 132

Figura 54 - Espectros de RPE do DMPO-OH, formado após irradiação, em diferentes tempos da mistura HY $50 \mu \mathrm{gL}^{-1}$ e DMPO 0,5 mol L-1 em PBS $(\mathrm{pH} \mathrm{7,4)}$ com LED $630 \mathrm{~nm}, \mathrm{l}=10 \mathrm{~mW} \mathrm{~cm}{ }^{-2}$

Figura 55 - Reação do DMPO com radical $\mathrm{O}_{2}{ }^{-*}$ formando o aduto DMPO-OH ... 135 Figura 56 - Intensidade de formação de DMPO-OH, formado após irradiação com LED $630 \mathrm{~nm}, \mathrm{I}=10 \mathrm{~mW} \mathrm{~cm}{ }^{-2}$ de uma mistura de $\mathrm{HY} 50 \mu \mathrm{gL}^{-1}$ e DMPO $0,5 \mathrm{~mol} \mathrm{~L}^{-1} \mathrm{em}$ PBS (pH 7,4), em função do tempo de irradiação 136

Figura 57 - Espectro de RPE do DMPO-OH, formado após irradiação com LED $630 \mathrm{~nm}, \mathrm{l}=10 \mathrm{~mW} \mathrm{~cm}^{-2}$ contendo PZ $50 \mathrm{\mu g} \mathrm{mL}^{-1}$ e DMPO 0,5 mol L-1 e PBS (pH 7,4), em função do tempo 137

Figura 58 - Intensidade de formação de DMPO-OH, formado após irradiação com LED $630 \mathrm{~nm}, \mathrm{l}=10 \mathrm{~mW} \mathrm{~cm}{ }^{-2}$ de uma mistura de PZ $50 \mu \mathrm{gL}^{-1}$ e DMPO 0,5 mol L-1 em PBS (pH 7,4), em função do tempo de irradiação

Figura 59 - Espectro de RPE do DMPO-OH, formado após irradiação com LED $630 \mathrm{~nm}, \mathrm{l}=10 \mathrm{~mW} \mathrm{~cm}{ }^{-2}$ contendo PG $50 \mu \mathrm{g} \mathrm{mL}^{-1}$ e DMPO 0,5 mol L-1 em PBS (pH $7,4)$, em função do tempo 139 
Figura 60 - Intensidade de formação de DMPO-OH, formado após irradiação com LED $630 \mathrm{~nm}, \mathrm{I}=10 \mathrm{~mW} \mathrm{~cm}^{-2}$ de uma mistura de PG $50 \mathrm{\mu g} \mathrm{mL}^{-1}$ e DMPO 0,5 mol L-1 em PBS (pH 7,4), em função do tempo de irradiação 


\section{ÍNDICE DE TABELAS}

Tabela I - Resultados dos índices de sobrevivência da HEp-2 em função da dose de luz recebida dos LEDs vermelho e amarelo. Os experimentos foram feitos três vezes em sextuplicata

Tabela II - Resultados dos índices de sobrevivência da Vero em função da dose de luz recebida dos LEDs vermelho e amarelo. Os experimentos foram feitos três vezes em sextuplicata 89

Tabela III - Valores de $\mathrm{IC}_{50}$ da HY, PZ e PG para a linhagem HEp-2 após $2 \mathrm{~h}$ de incubação e irradiada com LED vermelho, $\mathrm{l}=18 \mathrm{~mW} \mathrm{~cm}{ }^{-2}$ em diferentes doses de luz. Os experimentos foram realizados cinco vezes em sextuplicata para cada concentração

Tabela IV - Valores de IC 50 da HY, PZ e PG para a linhagem Vero após 2 h de incubação e irradiada com LED vermelho, $\mathrm{I}=18 \mathrm{~mW} \mathrm{~cm}{ }^{-2}$ em diferentes doses de luz. O experimentos foram realizados cinco vezes em sextuplicata para cada concentração 93

Tabela V - Valores de $\mathrm{IC}_{50}$ dos FSs HY, PZ e PG para a linhagem B16-F10 após 2 h de incubação e irradiada por 15 min com LED $\Lambda=632 \mathrm{~nm}, \mathrm{l}=18 \mathrm{~mW} \mathrm{~cm}^{-2}$. Os experimentos foram realizados quatro vezes em sextuplicata para cada concentração 95

Tabela VI - Valores de IC $\mathrm{I}_{50}$ dos FS HY, PZ e PG para a linhagem McCoy após $2 \mathrm{~h}$ de incubação e irradiada por $15 \min$ com LED $\Lambda=632 \mathrm{~nm}, \mathrm{l}=18 \mathrm{~mW} \mathrm{~cm}{ }^{-2}$. Os experimentos foram feitos cinco vezes em sextuplicata para cada concentração 96 
Tabela VII - Valores de $\mathrm{IC}_{50}$ dos FS HY, PZ e PG para a linhagem HEp-2 após $2 \mathrm{~h}$ de incubação e irradiados em diferentes doses de luz com LED $\Lambda=590 \mathrm{~nm}$, I= $10 \mathrm{~mW} \mathrm{~cm}^{-2}$. Os experimentos foram feitos três vezes em sextuplicata para cada concentração 98

Tabela VIII - Valores de $I_{50}$ para a linhagem Vero após 2 h de incubação e HY, PZ e PG irradiados em diferentes doses de luz com LED $\Lambda=590 \mathrm{~nm}$. Os experimentos foram feitos três vezes em sextuplicata para cada concentração

Tabela IX - Valores das constantes de velocidade da reação de fotoxidação de BSA $\left(2 \times 10^{-3} \mathrm{~mol} \mathrm{~L}^{-1}\right)$ na presença de FS $\left(1 \mu \mathrm{g} \mathrm{mL} \mathrm{m}^{-1}\right)$ em PBS, obtidas através da irradiação das amostras com LED $\left(\Lambda=632 \mathrm{~nm}, \mathrm{I}=18 \mathrm{~mW} \mathrm{~cm}{ }^{-2}, \mathrm{t}=60 \mathrm{~min}\right)$. Os ensaios foram realizados em triplicata 105

Tabela X - Coeficientes de partição obtidos para os fotossensibilizadores. Os ensaios foram realizados em triplicata 108

Tabela XI - Coeficientes de Atividade Fotodinâmica dos FSs correspondendo a média de três experimentos realizados em triplicata

Tabela XII - Resultados de absorbâncias, áreas dos espectros de emissão e rendimento quânticos de fluorescência dos FS. Os experimentos foram realizados em triplicata 


\section{LISTA DE ABREVIATURAS}

BSA - albumina de soro bovino

CEPID - centro de pesquisa, inovação e difusão

DNA - ácido desoxirribonucléico

EROs - espécies reativas de oxigênio

FS - fotossensibilizador

FSs - fotossensibilizadores

HEp-2- linhagem celular tumoral de laringe humana

$\mathrm{HpD}$ - derivados de hematoporfirina

HY - Hipericina

LED - Ligth Emitting Diode (diodos emissores de luz)

PG - Photogem

PZ - Photodithazine

RPE - Ressonância Paramagnética Eletrônica

SDS - dodecil sulfato de sódio

SFB - soro fetal bovino

TFD - Terapia Fotodinâmica

Vero - linhagem normal de rim de macaco 


\section{SUMÁRIO}

\section{INTRODUÇÃO}

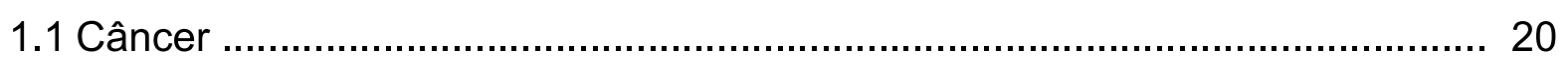

1.2 Terapias convencionais para o câncer ...................................................... 22

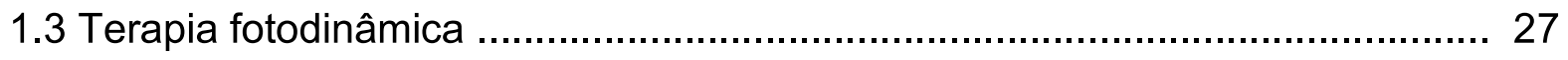

1.4 Processos fotoquímicos envolvidos na terapia fotodinâmica .......................... 27

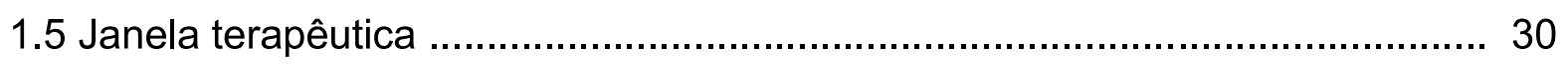

1.6 Propriedades de um fotossensibilizador ideal ............................................ 31

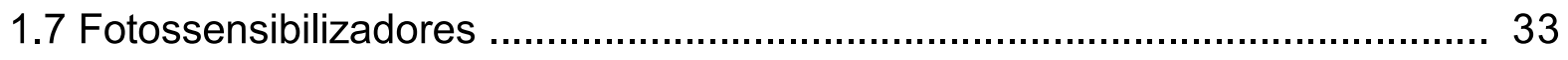

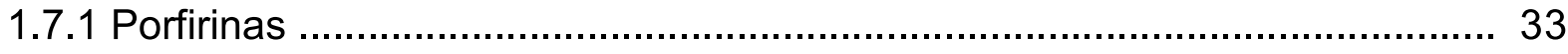

1.7.2 Fotossensibilizadores de primeira geração ................................................ 34

1.7.3 Fotossensibilizadores de segunda geração ............................................... 36

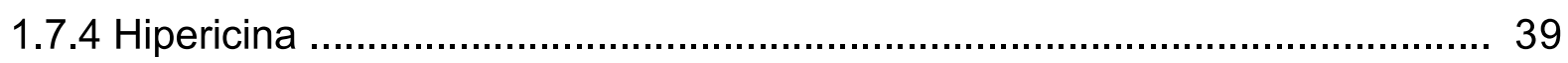

1.8 Sistemas óticos para a fotossensibilização ………..................................... 41

1.9 Avaliação da eficiência dos fotossensibilizadores ........................................ 40

1.9.1 Fotoxidação da albumina bovina ……………................................... 43

1.9.2 Coeficiente de partição ....................................................................... 44

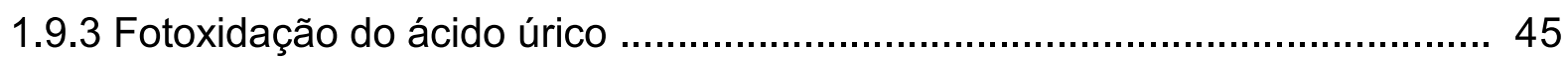

1.9.4 Rendimento quântico de fluorescência ..................................................... 46

1.9.5 Ensaios citotóxicos em cultura celular ………................................... 48

1.10 Transporte e acumulação dos fotossensibilizadores pelas células ................ 50

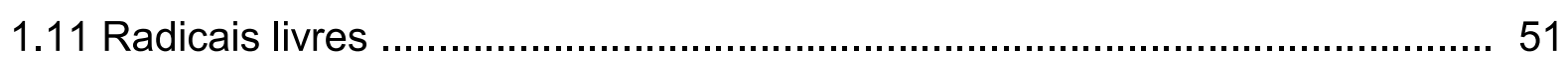

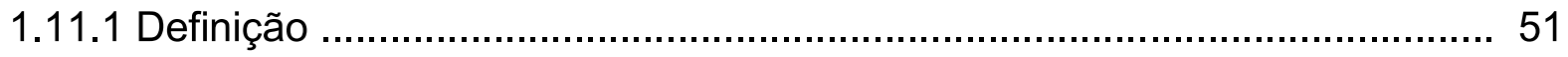

1.11.2 Deteç̧ão de radicais livres ........................................................... 52 


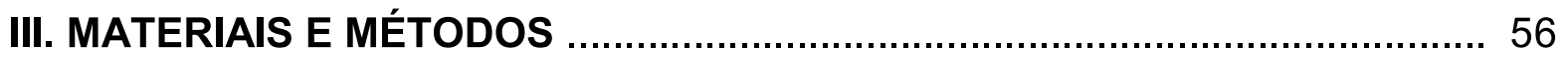

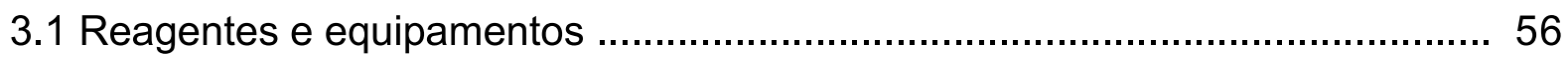

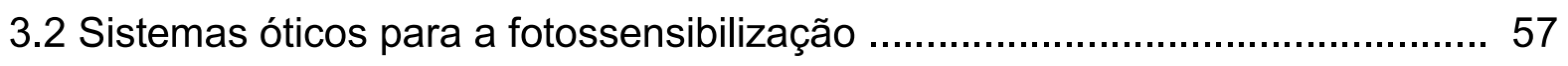

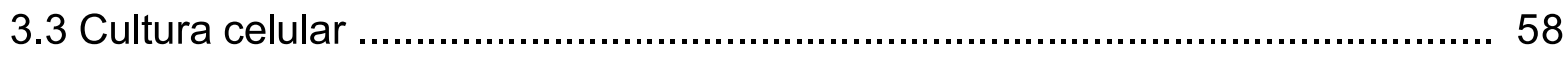

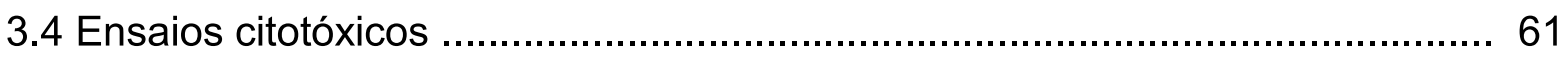

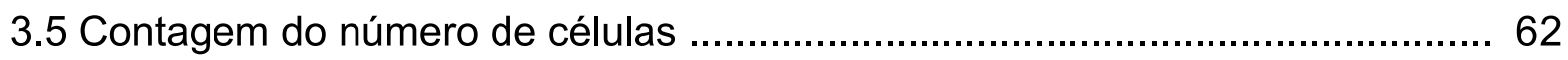

3.6 Fotoxidação dos aminoácidos com albumina de soro bovino.......................... 62

3.7 Determinação dos coeficientes de partição dos fotossensibilizadores ............. 65

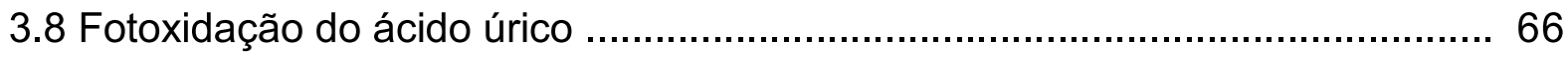

3.9 Rendimento quântico de fluorescência dos FSs ......................................... 67

3.10 Acumulação de fotossensibilizadores em células HEp-2 e Vero .....................68 68

3.11 Determinação dos radicais livres por spin trapping ………......................... 69

3.12 Cálculo da média amostral e do desvio padrão e análise estatística dos dados

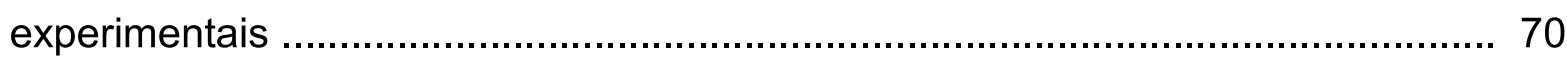

3.13 Descarte dos resíduos gerados nos experimentos …................................. 71

\section{RESULTADOS E DISCUSSÕES}

4.1 Espectros de absorção ótica dos fotossensibilizadores ................................. 72

4.2 Agregação dos fotossensibilizadores ………………................................ 75

4.3 Estudo da estabilidade da Hipericina, Photodithazine e Photogem em função do tempo de armazenamento

4.4 Estudo da estabilidade da Hipericina, Photodithazine e Photogem em função do tempo de irradiação 
4.5 Experimentos citotóxicos

4.5.1 Efeito do DMSO em cultura de células .............................................. 86

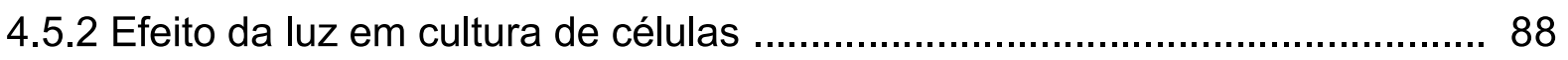

4.5.3 Efeito da dose de irradiação na fototoxicidade da HY, PZ e PG ................. 90

4.6 Interação dos FSs com albumina de soro bovino .................................... 102

4.7 Determinação dos coeficientes de partição dos FSs ................................. 107

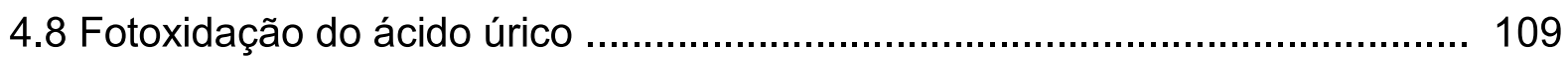

4.9 Determinação do rendimento quântico de fluorescência da Hipericina, Photodithazine e Photogem em etanol ....................................................... 114

4.10 Acumulação intracelular de Hipericina, Photogem e Photodithazine ........... 116

4.11 Determinação dos radicais livres por ressonância paramagnética eletrônica.133

V.CONCLUSÕES 


\section{INTRODUÇÃO}

\subsection{Câncer}

O câncer é uma das doenças que mais causam temor na sociedade, por ter se tornado um estigma de mortalidade e dor. Na verdade, a palavra câncer de origem latina (cancer) significando "caranguejo" deve ter sido empregada em analogia ao modo de crescimento infiltrante, que pode ser comparado às pernas do crustáceo, que as introduz na areia ou lama para se fixar e dificultar sua remoção ${ }^{1,2}$.

Câncer ou enfermidades oncológicas são denominações utilizadas para descrever um grupo de doenças que se caracterizam pela anormalidade das células e sua divisão excessiva. O câncer é causado, na maioria das vezes, por mutação ou por ativação anormal de genes celulares (oncogenes), que controlam a mitose e o crescimento celular. Essas células mutantes, de maneira geral, apresentam menor capacidade de sobrevivência, pois são com grande freqüência, destruídas pelo sistema imune do corpo antes que possam formar um câncer. Entretanto, a probabilidade de ocorrência de mutações pode ser aumentada muitas vezes quando a pessoa é exposta a determinados fatores físicos, químicos e biológicos, entre eles: radiação ionizante (raios-X, raios- $v$, ultravioleta), irritantes físicos (abrasão do tecido), compostos químicos carcinogênicos, tendência hereditária, entre outros ${ }^{3}$. Existem muitas causas para o câncer, podendo ser classificadas em externas e internas ao organismo, estando ambas relacionadas entre si. As causas externas podem ser encontradas no meio ambiente e correspondem a maioria dos 
casos (cerca de $80 \%$ ), onde encontram-se um grande número de fatores de risco. Entende-se por ambiente, o meio em geral (água, terra e ar), o ambiente ocupacional (quando insalubre), o ambiente social e cultural (estilo e hábitos de vida) e o ambiente de consumo (alimentos, medicamentos). As mudanças provocadas no meio ambiente pelo próprio homem, os hábitos e estilos de vida adotados pelas pessoas podem determinar os diferentes tipos de câncer. As causas internas estão relacionadas em sua totalidade à capacidade do organismo de se defender das agressões externas ${ }^{4}$.

A questão mais importante sobre tumores é a distinção entre tumor maligno e benigno. Um tumor é qualquer proliferação anormal de células, um tumor benigno, como uma verruga comum de pele, permanece confinado ao seu local de origem, não invade o tecido normal circundante e não se espalha em locais distantes do corpo. Um tumor maligno, entretanto, é capaz de invadir tecidos vizinhos e distantes do corpo através do sistema circulatório ou linfático (metástase) ${ }^{5}$.

Tumores malignos, se não tratados adequadamente, podem ser fatais, podendo ser classificados como: carcinoma, derivado originalmente de células embrionárias epiteliais, tecidos que se desenvolveram a partir do epitélio embrionário, que incluem a pele, o envoltório de muitos órgãos, como os órgãos do trato urinário, pulmão, bexiga e esôfago; sarcoma, que é tipo de câncer derivado originalmente de células de tecido embrionário conjuntivo, incluindo músculo, osso e cartilagem; linfoma são neoplasias malignas, originárias dos gânglios linfáticos (ou linfonodos), órgãos muito importantes no combate a infecções ${ }^{6}$.

Os tipos mais comuns de câncer são os de pele, mama feminina, próstata, pulmão e estômago sendo que os quatro últimos são mais letais ${ }^{2}$. O câncer é 
considerado a segunda causa de morte no Brasil e nos Estados Unidos, perdendo apenas para as doenças cardiovasculares ${ }^{2,7}$. Por isso, estudos relacionados ao câncer são de extrema importância, principalmente no que concerne a novas modalidades terapêuticas.

\subsection{Terapias convencionais para o câncer}

Os tratamentos convencionais do câncer são cirurgia, radioterapia (braquiterapia) e quimioterapia ${ }^{8}$. Entre as terapias convencionais, todas apresentam efeitos benéficos no combate ao câncer, entretanto apresentam efeitos colaterais indesejáveis. A cirurgia, que consiste na remoção do tumor, apesar de uma das técnicas mais utilizadas no tratamento do câncer, causa severas mutilações nos pacientes. A radioterapia é um método capaz de destruir células tumorais, empregando feixe de radiações ionizantes. Uma dose pré-calculada de radiação é aplicada, em um determinado tempo, a um volume de tecido que engloba o tumor, buscando erradicar todas as células tumorais, com o menor dano possível às células normais circunvizinhas, à custa das quais se fará a regeneração da área irradiada. A quimioterapia, como o próprio nome já diz, baseia-se na utilização de compostos químicos, tais como agentes alquilantes e antimetabólicos. Enquanto a cirurgia e a radioterapia limitam-se a eliminar as células malignas de uma área restrita, a quimioterapia tem a capacidade de alcançá-las dentro do organismo. Os agentes alquilantes são compostos orgânicos reativos que transferem grupos alquila às bases nitrogenadas do ácido desoxirribonucléico (DNA) por terem estrutura molecular semelhante aos compostos utilizados na síntese desta molécula. Um 
exemplo é o metotrexato, que se assemelha em estrutura ao ácido fólico, utilizado na síntese dos ácidos nucléicos. As drogas quimioterápicas apresentam uma série de efeitos colaterais indesejáveis. Em geral, estas drogas afetam o crescimento celular, especialmente das células que se multiplicam rapidamente, como as células tumorais. Entretanto existem células normais que também têm multiplicação rápida, como as células de defesa do sangue, que combatem infecções, as células que recobrem o aparelho digestivo e as células dos folículos pilosos. Em conseqüência disso os pacientes apresentam sérias reações adversas, tais como menor resistência a infecções, perda de apetite, náusea, vômito, diminuição da salivação e queda de cabelo ${ }^{8}$. A terapia citotóxica do câncer baseia-se no princípio de que as drogas matam uma fração constante e ainda de que as células possam ter um período distinto de vulnerabilidade às drogas citotóxicas. Desta forma, pode-se dizer que as drogas citotóxicas reduzem a evolução das células ao longo do ciclo celular e também não apresentam uma toxicidade seletiva para as células cancerosas, já que a citotoxicidade é proporcional à exposição total a droga ${ }^{3}$.

Diante dos graves efeitos colaterais e da eficiência limitada das terapias tradicionais, alternativas estão sendo constantemente propostas. Dentre estas se destaca a Terapia Fotodinâmica (TFD), uma modalidade relativamente nova no tratamento de câncer. Apesar de boa parte do uso da TFD ser centrada nesta doença, outras moléstias tais como degeneração macular da retina, psoríase, artrite reumatóide sistêmica, restenosis, micoses fungóides, infestações bacterianas, verrugas, arteriosclerose, síndrome da imunodeficiência adquirida (do inglês, AIDS), etc. também podem ser tratadas com TFD, uma vez que têm como característica comum um crescimento anormal de tecidos. Assim a TFD está sendo usada e 
investigada em nível mundial no tratamento dessas e outras doenças correlatas na origem $^{9}$.

\subsection{Terapia fotodinâmica}

A Terapia Fotodinâmica é uma nova e promissora modalidade de tratamento do câncer e caracteriza-se por um conjunto de processos físicos, químicos e biológicos que ocorre após a administração de uma substância sensível à luz, chamada de fotossensibilizador (FS), que fica retida preferivelmente nos tecidos tumorais, seguida pela irradiação com luz visível ${ }^{10,11}$. Embora se considere como um marco da fototerapia o trabalho desenvolvido por Finsen em 1960 na Europa ${ }^{12}$, luz visível já era empregada como agente terapêutico há mais de 4000 anos no Egito, Índia e China para o tratamento de psoríases, vitiligo, raquitismo e câncer ${ }^{13}$.

Este tratamento, que se baseia nas propriedades benéficas do uso combinado de luz com o FS; é conhecido e estudado desde o início do século passado, no entanto, teve seu impulso retomado como terapia para o câncer somente no início da década de 70 com os experimentos de Dougherty ${ }^{14}$ para analisar as propriedades de um derivado de hematoporfirina $(\mathrm{HpD})$ capaz de agir tanto como localizador ótico quanto como um FS seletivo destrutivo de células tumorais $^{15}$.

A técnica da TFD envolve a interação simultânea de um FS, luz e oxigênio molecular existente nas células. A droga injetada na corrente sanguínea percorre todo o corpo, sendo absorvida por todas as células, no entanto, as células sadias eliminam essa droga em um período de tempo que varia de 24 a $36 \mathrm{~h}$, enquanto as 
células cancerosas, que apresentam um metabolismo diferente, retêm esta droga por um tempo mais prolongado, em torno de $72 \mathrm{~h}$. Esperando-se $24 \mathrm{~h}$ após a administração da droga, a substância fotossensível estará mais concentrada nas células cancerosas, estabelecendo uma diferenciação entre estas células e as demais. Essa substância fotossensível, quando iluminada por uma luz de comprimento de onda específico, é então excitada e, uma vez neste estado energético, provoca uma reação fotoquímica com o oxigênio molecular, produzindo espécies reativas de oxigênio (EROs): ${ }^{1} \mathrm{O}_{2}, \mathrm{O}_{2}{ }^{-*},{ }^{\star} \mathrm{OH}, \mathrm{H}_{2} \mathrm{O}_{2}$, que são altamente reativas com os constituintes celulares e, portanto, bastante citotóxicas. Como conseqüência disso, a célula cancerosa e o tecido tumoral como um todo é levado à morte por apoptose ou necrose, eliminando a lesão cancerosa, e, posteriormente, permitindo a completa restauração do tecido ${ }^{16,17}$. Em certos casos, onde a cirurgia do tumor é complexa devido ao seu tamanho ou ao acesso, recomenda-se a aplicação da TFD como tratamento pré-operatório para promover a diminuição do mesmo. A TFD é adequada para tumores médios e pequenos. De modo geral, para a aplicação da técnica, após diagnóstico e avaliação rigorosa do problema clínico, o medicamento é solubilizado em água ou soro fisiológico. A solução é administrada intra-venosamente e espera-se o tempo para acúmulo do FS no tecido. O processo de infusão do FS deve ser lento e cuidadoso diante da possibilidade de extravasamento devido à fragilidade da parede celular das veias ${ }^{18}$. Um esquema da aplicação da TFD está apresentado na Figura 1. 


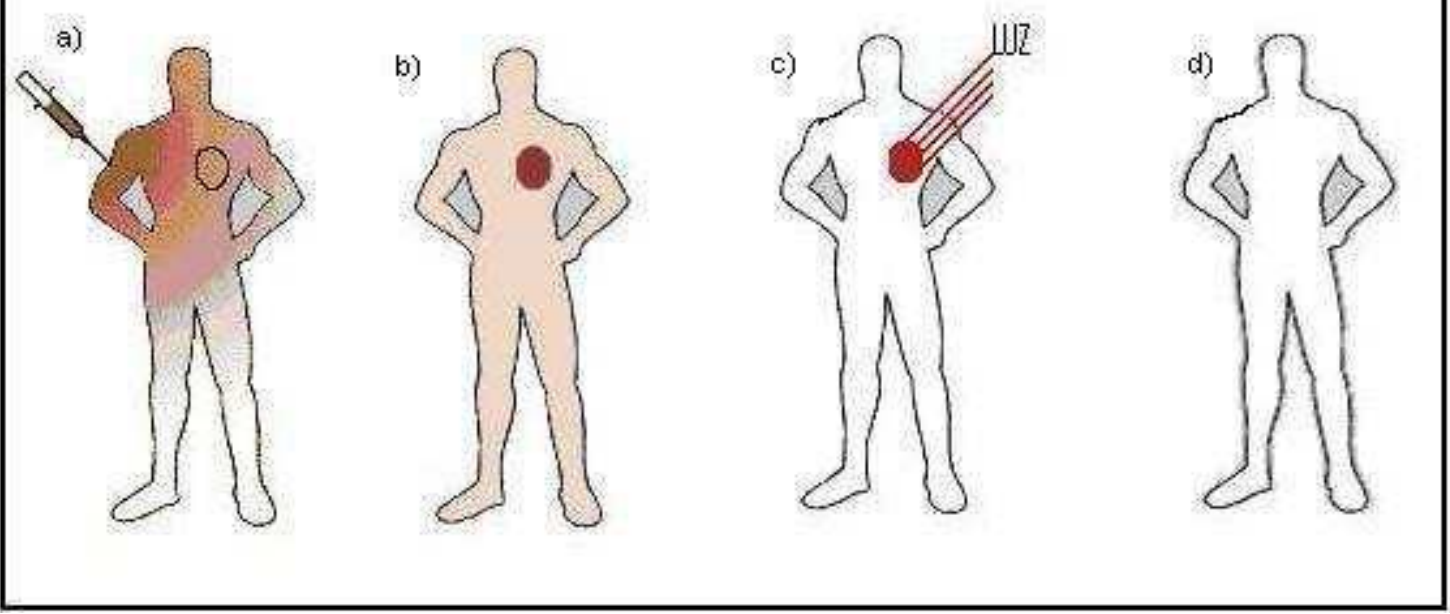

Figura 1 - Esquema de aplicação da TFD: a) Paciente com tumor recebendo FS intravenoso; b) FS localizado no tumor após certo tempo; c) tumor sendo irradiado por luz visível de comprimento de onda adequado; d) desaparecimento do tumor ${ }^{19}$.

A TFD é uma modalidade de tratamento que pode ser repetida quantas vezes forem necessárias, sendo esta uma de suas maiores vantagens em relação aos incômodos das outras modalidades de tratamento ${ }^{20}$. No entanto, tratando-se de uma terapia que envolve um FS, deve-se tomar precauções quanto à exposição ao sol, já que a pele se torna altamente sensível à luz, sendo este o único efeito indesejado ${ }^{21}$. Esta modalidade de tratamento tem sido utilizada com sucesso em casos de tumores onde a aplicação da luz é facilitada, ou seja, tumores externos como câncer de pele, tumores de mama, tumores em cavidades como pulmão, cavidade oral, bexiga, ovário e cólon que podem ser iluminados, sendo que neste caso a aplicação de luz pode ser feita através de endoscópio acoplado a fibras óticas ${ }^{22}$. A TFD é essencialmente uma terapia nova de tratamento dos pacientes com tumores malignos, no entanto a eficácia do tratamento é dependente do tipo de neoplasia, estágio da doença, do FS utilizado e condições de irradiação do tecido doente, como comprimento de onda da luz e dose ${ }^{14}$. 


\subsection{Processos fotoquímicos envolvidos na terapia fotodinâmica}

O mecanismo de fotossensibilização consiste na interação da luz de comprimento de onda adequado com o FS e o oxigênio molecular, resultando em espécies reativas que induzem a inviabilização das células. Quando o FS é irradiado com luz absorve um fóton e com isso um dos seus elétrons passam para o orbital energeticamente mais alto, mas de mesmo spin, resultando em um estado excitado singlete. Estados excitados singletes têm tempo de vida curto (1-100 ns). Após a excitação todos os processos que contribuem para a desativação do estado excitado competem entre si. Um elétron que é excitado a um nível vibracional superior ao estado excitado tende preferencialmente a dissipar esse excesso de energia descendo até o nível vibracional zero do estado excitado correspondente. Isso se dá através de colisões com as moléculas de solvente, esse processo é chamado de relaxação vibracional, que é normalmente mais rápido do que os processos intramoleculares envolvendo transições entre estados eletrônicos ${ }^{23}$.

A conversão interna é o processo em que a energia de excitação é perdida por colisão com o solvente ou por dissipação através dos modos vibracionais internos. Geralmente a conversão interna e a temperatura são diretamente proporcionais, conseqüentemente a fluorescência decresce com o aumento da temperatura. O cruzamento intersistema é um processo isoenergético e sua troca de spin, nominalmente proibida, converte um singlete excitado em um estado triplete excitado, que decai prontamente para o nível vibracional T1 que se converte para o estado singlete fundamental, tanto por fosforescência (emissão de energia) quanto por conversão interna. Geralmente o estado triplete tem energia mais baixa que o 
singlete excitado, portanto a fosforescência ocorre em comprimentos de ondas maiores que a fluorescência. Como a transição envolvida na fosforescência envolve mudança de multiplicidade, o tempo de vida é muito mais longo que o tempo de vida de fluorescência. Um terceiro processo não radiativo denominado supressão de fluorescência é geralmente o resultado de colisões ou da formação de complexos com solutos moleculares capazes de reduzir o tempo de vida do estado excitado ou manter o complexo no estado fundamental provocando a supressão de fluorescência.

A conversão interna entre os estados singlete de energias mais altas, tal como $S_{3} \longrightarrow S_{2}$ é muito mais rápida que as taxas das conversões que foram consideradas $\left(\mathrm{S}_{1} \longrightarrow \mathrm{S}_{0}\right)$. A relaxação vibracional dos níveis vibracionais excitados de cada estado eletrônico é mais rápida que a emissão de fóton. O resultado é que toda fluorescência que se observa é normalmente originária do nível vibracional fundamental do singlete excitado ${ }^{23}$.

Uma das propriedades desejáveis para um bom FS é uma alta eficiência para sofrer cruzamento inter-sistemas. Como o tempo de vida do estado triplete é relativamente longo $\left(10^{-3}\right.$ a $\left.10 \mathrm{~s}\right)$, o FS excitado pode interagir com moléculas vizinhas. A Figura 2 representa o Diagrama de Jablonski, com os níveis de energia eletrônico/vibracional de um FS excitado através de uma fonte de excitação a um determinado nível de energia ${ }^{23}$. 


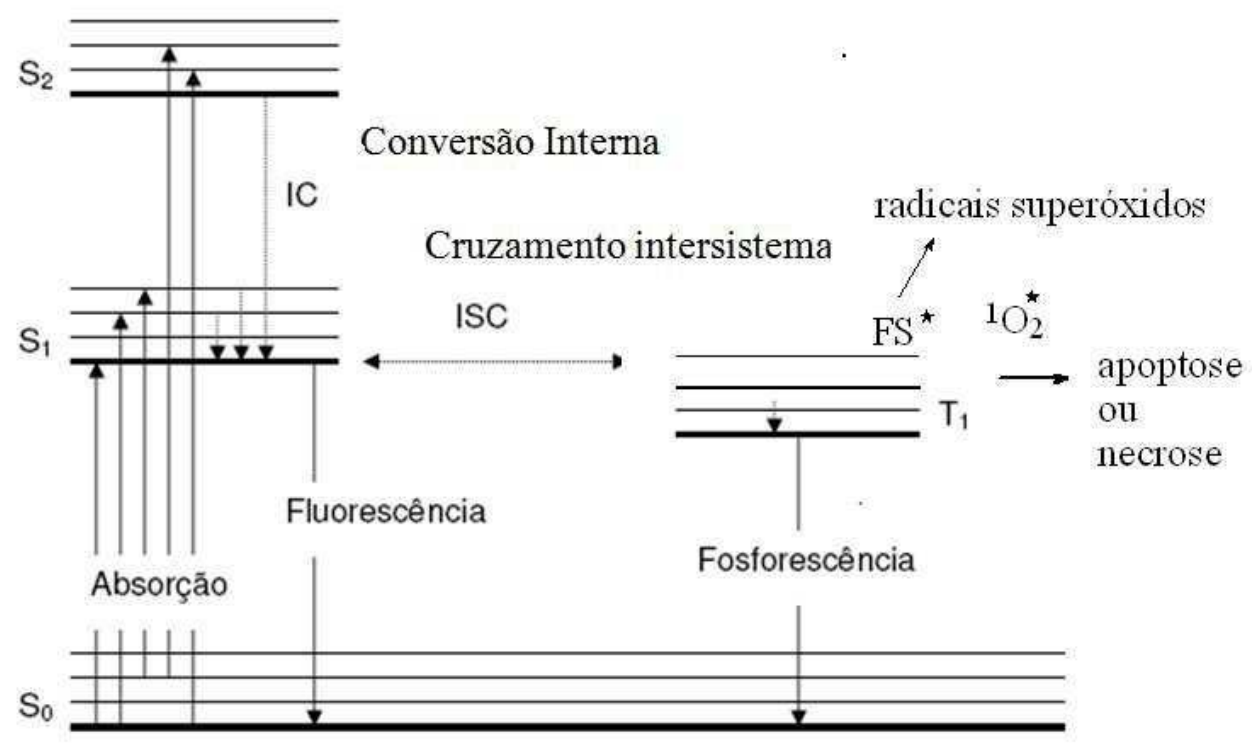

Figura 2 - Diagrama de Jablonski: ilustração gráfica dos mecanismos fotoquímicos e fotofísicos em TFD $^{24}$.

Existem dois mecanismos de ação dos fotossensibilizadores sobre as biomoléculas: mecanismo do Tipo I e mecanismo do Tipo II ${ }^{25}$.

\section{Mecanismo tipo I ou via formação de radical}

O FS no estado triplete (estado excitado) interage diretamente com o substrato, através de reações de transferência de elétrons ou transferência de hidrogênio, gerando radicais ou íons radicais, os quais reagem com o oxigênio produzindo uma mistura de intermediários de oxigênio altamente reativos, como radical superóxido $\left({ }^{\circ} \mathrm{O}_{2}^{-}\right)$, peróxido de hidrogênio $\left(\mathrm{H}_{2} \mathrm{O}_{2}\right)$ e radical hidroxila $\left({ }^{\circ} \mathrm{OH}\right)$, capazes de oxidar uma grande variedade de biomoléculas ${ }^{26}$. 


\section{Mecanismo tipo II ou via formação de oxigênio singlete (transferência de energia)}

O FS no estado triplete transfere energia ao oxigênio molecular no estado fundamental (triplete) produzindo oxigênio singlete. O oxigênio singlete é uma forma reativa de oxigênio e é considerado o principal mediador do dano fotoquímico

causado à célula por muitos fotossensibilizadores ${ }^{27}$. O oxigênio singlete possui tempo de vida em água de aproximadamente 4 us e em sistemas biológicos esse tempo é extremamente baixo, inferior a 0,04 $\mu$ s. Em função disso, seu raio de ação é muito reduzido, menor que $0,02 \mu \mathrm{m}$, atuando apenas onde é produzido, fato muito importante para TFD que se baseia no efeito fotodinâmico localizado e seletivo ${ }^{28}$.

\subsection{Janela terapêutica}

A interação da luz com o tecido é uma função complexa das propriedades óticas do tecido, uma vez que a absorção e o espalhamento da luz são dependentes do comprimento de onda. Os tecidos normais contêm muitas substâncias que absorvem ou refletem radiação eletromagnética. As proteínas e o DNA absorvem na faixa do ultravioleta $(200-350 \mathrm{~nm})$, a melanina absorve em comprimentos de onda baixos entre 200 e 300 nm e no visível entre 315 e 400 nm e a hemoglobina absorve na região entre 400-600 nm. A água absorve na região do infravermelho, acima de $800 \mathrm{~nm}$, assim resta apenas a faixa compreendida entre $600-800 \mathrm{~nm}$ na qual os tecidos são relativamente transparentes. Esta faixa de comprimento de onda é conhecida como "janela terapêutica" e pode ser utilizada em terapia fotodinâmica. O 
decréscimo na intensidade da luz no tecido exposto de um feixe de luz plano de diferentes comprimentos de onda em função da penetração está representado na Figura 3. Pode-se verificar que a luz de comprimento de onda maior penetra mais profundamente, principalmente porque na região entre 600 e 700 nm não há competição dos cromóforos endógenos. O emprego de luz de comprimento de onda acima de $850 \mathrm{~nm}$ é descartado uma vez que nesse caso os fótons não possuem energia suficiente para ativar o FS.

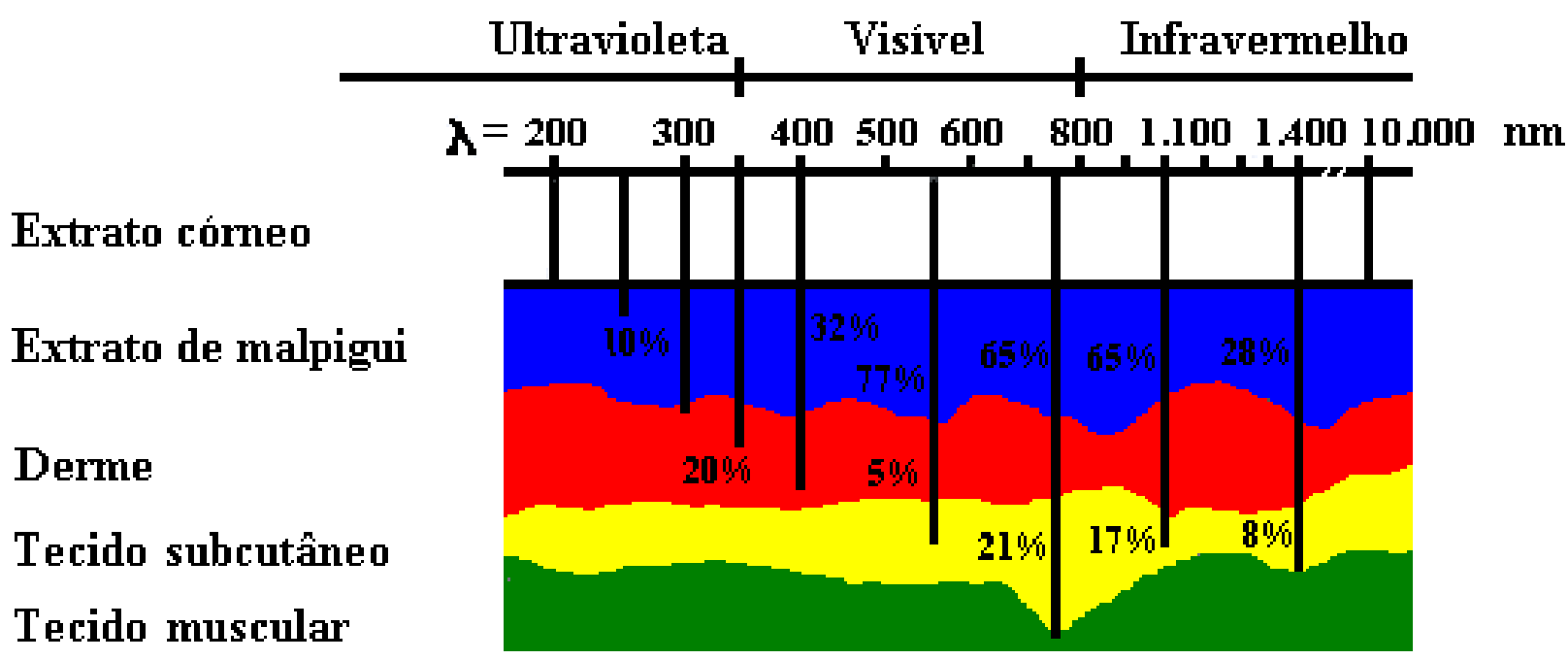

Figura 3 - Representação esquemática de um corte de tecido humano e o percentual de penetração da luz de diferentes comprimentos de onda ${ }^{30}$.

\subsection{Propriedades de um fotossensibilizador ideal}

Atualmente, diversos grupos de pesquisas de vários países estão tentando aperfeiçoar a TFD e a cada ano surgem muitos compostos com potencial para 
serem utilizados como fotossensibilizadores. Uma substância química para atuar como FS deve ter certas propriedades específicas, tais como:

- Apresentar composição química constante a fim de simplificar a interpretação da relação dose-resposta nos estudos de dosimetria.

- Ser solúvel e permanecer estável em solução aquosa a pH fisiológico, ou através de lipossomas para permitir circulação e acúmulo seletivo nas células;

- Apresentar seletividade quanto à retenção por células malignas após algumas horas da introdução da droga na corrente sangüínea. Isto se deve ao fato de que o tecido normal elimina a droga com maior facilidade do que o cancerígeno, pois este apresenta um maior número de receptores de lipoproteínas responsáveis pela captação do FS;

- Ter habilidade para o transporte passivo ou ativo dentro das células e ter um alvo intracelular bem conhecido;

- Possuir alto rendimento quântico (facilidade para absorver ou emitir fótons) nos estados triplete ou singlete;

- Não ser tóxico a níveis terapêuticos, com mínima morbidez para o indivíduo;

- Ser metabolizado rapidamente, minimizando possíveis efeitos colaterais.

- Elevado coeficiente de absorção em comprimentos de onda maiores que 600 nm, onde a penetração da luz através dos tecidos é facilitada, o que possibilita o tratamento de lesões mais profundas ${ }^{31}$. 


\subsection{Fotossensibilizadores}

\subsubsection{Porfirinas}

A classe de FSs mais estudada corresponde a de compostos derivados da hematoporfirina $(\mathrm{HpD})$, uma porfirina presente no sangue, mais especificamente no sítio ativo da hemoglobina, responsável pelo transporte e armazenamento de oxigênio na hemoglobina e mioglobina ${ }^{32}$. As porfirinas formam uma importante classe de compostos derivadas de um sistema aromático muito estável, do qual o membro mais simples é conhecido como porfina ${ }^{33}$. A Figura 4 apresenta a fórmula estrutural de uma porfina.

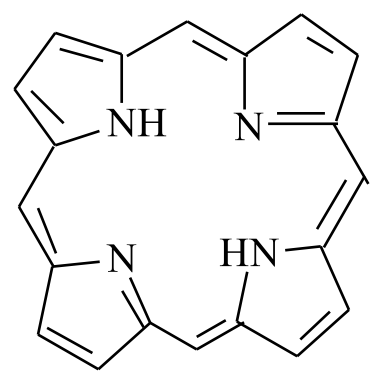

Figura 4 - Fórmula estrutural de uma porfina ${ }^{32}$.

Uma característica marcante das porfirinas é a facilidade com a qual elas formam quelatos com íons metálicos. O metal fixa-se rigidamente no espaço deixado pelos quatro átomos de nitrogênio do sistema planar, como é o caso da formação do heme, quando a porfirina se complexa com o átomo de $\mathrm{Fe}^{2+}$ e da formação da clorofila quando a porfirina encontra-se coordenada com o magnésio. Estas duas porfirinas, a proto-porfirina IX e a clorofila, são conhecidas como 
moléculas vitais, sendo responsáveis pela manutenção das principais formas de vida, tanto do mundo animal como do vegetal ${ }^{33}$.

\subsubsection{Fotossensibilizadores de primeira geração}

Os sensibilizadores mais utilizados em estudos clínicos em TFD são os derivados de hematoporfirina $(\mathrm{HpD})$ que são considerados FSs de primeira geração 35 , entre estes destacam-se: Photofrin $®$ (de origem americana), Photosan $®$ (de origem alemã) e Photogem ${ }^{\circledR}$ (de origem russa). Estes FSs consistem de uma mistura complexa de vários componentes sendo monômeros, dímeros e oligômeros de até oito unidades de porfirina unidas por ligações éter ou éster ${ }^{36}$. Estes FSs são produzidos de acordo com a tecnologia original de desfibrilação do sangue de animais e de humanos, a partir de hematoporfirina IX existente na circulação sangüínea ${ }^{37}$.

Estes HpD apresentam espectro de absorção eletrônica contendo cinco bandas de absorção, sendo uma banda intensa na região de $400 \mathrm{~nm}$, conhecida como banda de Soret e quatro de menor intensidade em comprimentos de onda maiores, conhecidas como bandas- $Q^{38}$. Apesar de eficientes em quase todos os tipos de tumores, estes FSs não são considerados ideais, uma vez que apresentam elevada retenção cutânea, causando um efeito colateral indesejável que consiste na fotossensibilização cutânea do paciente que deve se proteger da exposição à luz solar ou luz brilhante por um período de 8 a 12 semanas, que é o tempo de retenção do $\mathrm{HpD}$ na pele ${ }^{39}$. Outro fato importante é que a última banda de absorção destes FSs encontra-se na faixa de $620-630 \mathrm{~nm}$ com baixo coeficiente de extinção. 
Deve-se salientar que neste comprimento de onda a penetração de luz nos tecidos não é ideal. Mesmo assim a irradiação é feita em $630 \mathrm{~nm}$ devido a dois principais fatores: em $400 \mathrm{~nm}$ vários constituintes do tecido (dentre eles a hemoglobina) absorvem luz causando interferências e em comprimentos de onda menores que $630 \mathrm{~nm}$ a penetração de luz nos tecidos é menor ${ }^{38}$. Estes FSs apresentam-se como uma mistura complexa de vários constituintes que formam agregados em diferentes extensões e diferentes ambientes, o que resulta em alterações na eficácia terapêutica da droga ${ }^{40}$.

Devido a todos os fatores mencionados acima, atualmente existe um grande número de estudos dedicados à obtenção de novos fármacos, tão eficientes quanto os FSs de primeira geração, com cinética de eliminação mais rápida e com absorção de luz em comprimentos de onda maiores ${ }^{41}$.

Neste trabalho um dos FSs utilizados foi o Photogem ${ }^{\circledR}$, preparado no Instituto de Alta Tecnologia Química em Moscou, Rússia, sendo aprovado para uso médico pelo Comitê de Farmacologia da Rússia desde $1999{ }^{37}$. Segundo alguns trabalhos, Photogem ${ }^{\circledR}$ possui características físicas, químicas e diagnósticas semelhantes ao Photofrin $^{\circledR}$ com relação ao aspecto terapêutico ${ }^{42,43}$. A estrutura monomérica do Photogem $^{\circledR}$, apresentada na Figura 5 , tem a fórmula molecular representada por $\left[\mathrm{C}_{34} \mathrm{H}_{38} \mathrm{~N}_{4} \mathrm{O}_{6}\right] \mathrm{n}$ e massa molecular variando de 598 a $2920 \mathrm{~g} \mathrm{~mol}^{-1}$. Nos grupos substituintes $\mathrm{R}_{1}$ e $\mathrm{R}_{2}$ ligam-se $\mathrm{CH}=(\mathrm{OH}) \mathrm{CH}_{3}, \mathrm{CH}=\mathrm{CH}_{2}$ ou a própria estrutura monomérica da porfirina e nos ligantes $R_{3}$ e $R_{4}$ se ligam $H$ ou a própria estrutura monomérica da porfirina podendo formar dímeros, trímeros e oligômeros ${ }^{37,33}$. 


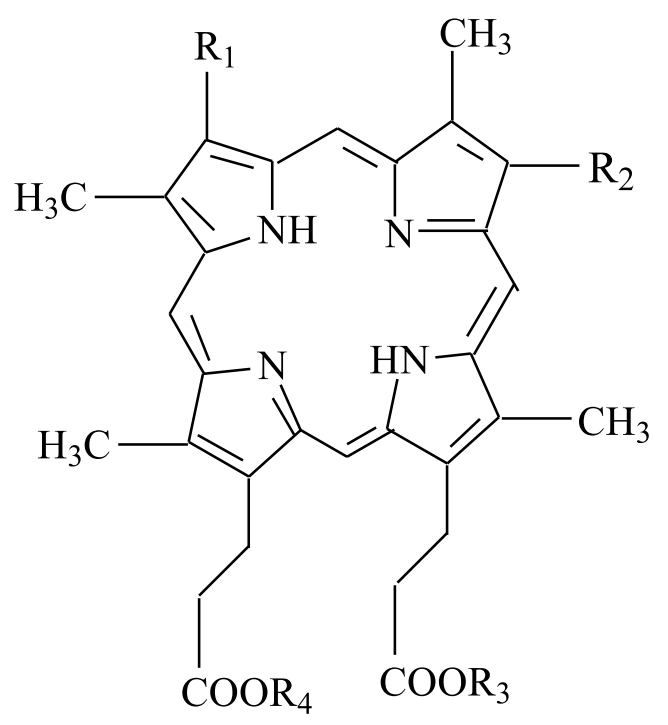

Figura 5 - Estrutura monomérica do Photogem ${ }^{37}$.

\subsubsection{Fotossensibilizadores de segunda geração}

Diversas modificações químicas no anel tetrapirrólico das porfirinas caracterizam o grupo de FSs de segunda geração. São compostos quimicamente puros com composição constante, que absorvem luz em comprimentos de onda maiores ou iguais a $650 \mathrm{~nm}$ e induzem pouca fotossensibilização cutânea. O tempo de meia vida é curto e a acumulação nos tecidos é seletiva e rápida (cerca de 1 a $6 \mathrm{~h}$ após a aplicação sistêmica). A estrutura básica destes compostos é semelhante à das porfirinas e são divididos em diferentes classes ${ }^{44}$ :

- ftalocianinas e naftalocianinas;

- clorinas e bacterioclorinas;

- purpurinas.

As ftalocianinas e naftalocianinas sintéticas são constituídas de quatro núcleos benzoindóicos unidos por pontes de nitrogênio. Estes compostos absorvem 
na faixa de comprimento de onda de $675-700 \mathrm{~nm}$ e podem ser ligados a uma variedade de metais, principalmente alumínio, silício e zinco, que levam a uma hexacoordenação responsável pelo aumento rendimento de geração de oxigênio singlete ${ }^{45}$. As ftalocianinas se acumulam na membrana plasmática, microssomos e mitocôndria ${ }^{44}$ e apresentam um período de fotossensibilidade de 8 a 10 dias, sendo um dos mais curtos entre todos ${ }^{44}$.

As clorinas e bacterioclorinas são derivadas de porfirinas hidrofílicas reduzidas pela hidrogenação de uma ou mais duplas ligações dos anéis pirrólicos, apresentam um coeficiente de extinção alto, além de uma intensa banda de absorção na região de 650-800 nm. Clorinas e bacterioclorinas estão presentes em produtos naturais (Spirulina, Rhodobacter capsulatus) e, de modo geral, estes compostos apresentam duas importantes propriedades: um alto rendimento quântico de formação de oxigênio singlete e uma intensa absorção em 650-680 nm. Exemplos de clorinas são: Foscan, Photoditazine e Radaclorina ${ }^{46}$. Foscan é o nome comercial do FS derivado de $m$-THPC (mesotetrakis(m-hidroxifenil)), produzido na Alemanha. O Photoditazine (PZ) é o segundo FS utilizado nesse trabalho, produzido a partir da cianobactéria Spirulina platensis, cuja estrutura foi modificada através da adição de N-metil-D-glicosamina 0,5\% como agente solubilizante e estabilizante e é encontrada em grande quantidade o que faz com que tenha um custo baixo. ${ }^{46}$. A fórmula estrutural do PZ está representada na Figura 6.

As propriedades fototóxicas do $P Z$ têm sido estudadas e a alta eficácia fotodinâmica parece estar relacionada com a sua capacidade de penetrar nas células através das membranas biológicas. O PZ é eliminado rapidamente do organismo, sendo que $94 \%$ da eliminação ocorre em 24 h e $98 \%$ em $48 \mathrm{~h}^{47}$. 


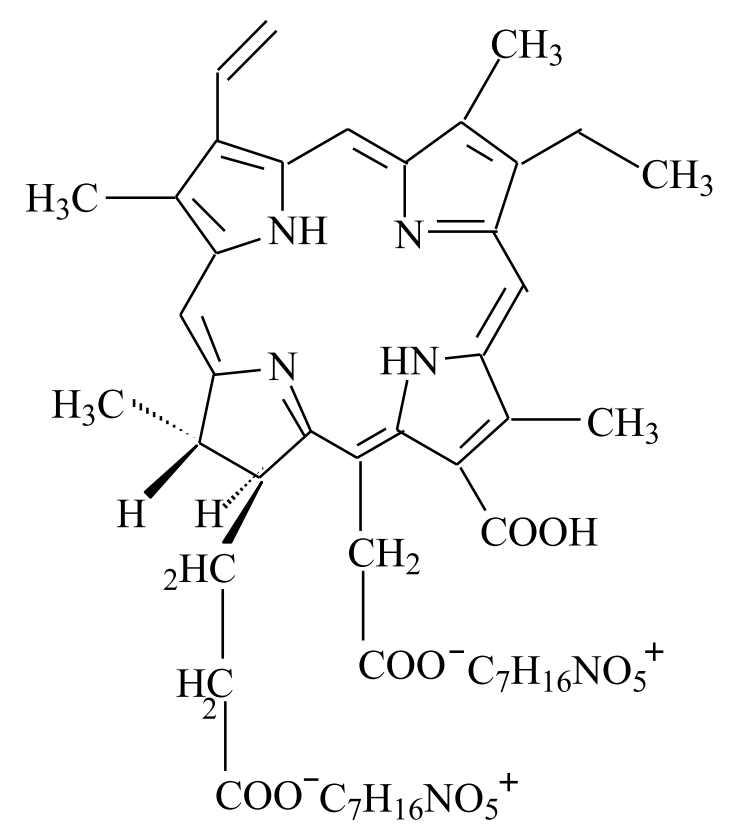

Figura 6 - Fórmula estrutural do Photodithazine ${ }^{46}$.

O Radachlorin é constituído de uma solução aquosa de três tipos de clorinas: clorina sódica e6 (90-95\%), clorina sódica p6 (5-7\%) e uma terceira clorina não revelada $(1-5 \%)^{48}$

As purpurinas são compostos hidrofóbicos que precisam ser administrados através de lipossomas e apresentam um grupo pirrólico reduzido. As purpurinas apresentam coloração púrpura, uma vez que a presença de um substituinte conjugado na posição meso da clorina altera a cor do pigmento anteriormente verde. Esses compostos absorvem fortemente na faixa de $630-715 \mathrm{~nm}$ e apresentam rendimento quântico de formação de oxigênio singlete de 0,6-0,7, sendo que a etilpurpurina de estanho $\left(\mathrm{SnEt}_{2}\right)$ é o derivado mais ativo desses compostos estudados $^{49}$.

Vários derivados de clorina têm sido estudados, dentre eles a monoaspartilclorina-e6 (Npe6 ou MACE), produzida no Japão, que é altamente solúvel 
em água e absorve em $654 \mathrm{~nm}$. O rendimento quântico de formação de oxigênio singlete é de 0,77 e apresenta efetividade in vitro e in vivo com baixa fotossensibilidade na pele, provavelmente por causa da sua rápida eliminação do corpo $^{49}$.

\subsubsection{Hipericina}

$\mathrm{Na}$ natureza existem muitas substâncias que podem atuar como fotossensibilizadores. Medicamentos populares derivados de plantas e utilizados para o tratamento de infecções superficiais são eficazes graças à atividade antifúngica e bactericida de FSs presentes nas plantas ${ }^{50}$. Os egípcios utilizavam os princípios da fotoquimioterapia para tratar o vitiligo através do uso das sementes de uma planta (Amni majus Linn) e luz solar. Atualmente a aplicação de psoralenos e luz ultravioleta tipo A dão origem à terapia com psoralenos e ultra-violeta A (PUVA), para tratamento de afecções cutâneas como vitiligo, psoríase, micose fungóide, líquen plano, dermatites atópicas e uma variedade de linfomas de células $\mathrm{T}^{51}$.

Hipericina (HY) (Figura 7) é um dos constituintes das plantas do gênero Hipericum, sendo o representante mais comum o Hipericum perforatum, uma planta herbácea perene com folhas amarelas douradas, popularmente conhecida como erva de São João ${ }^{52}$, pertencente à família das Hiperricoidaea guttiferae, é largamente distribuída na Europa, Ásia, norte da África e aclimatada nos Estados Unidos. Na Europa é comum encontrar o Hypericum perforatum na beira das estradas, vales e bosques ${ }^{53}$. Foi usada largamente na medicina popular em vários países da Europa, durante muitos séculos, para o tratamento de inflamações nos 
brônquios e infecções do trato geniturinário, agente cicatrizante no tratamento de feridas, traumas e queimaduras ${ }^{54}$.<smiles></smiles>

Figura 7 - Fórmula estrutural da Hipericina ${ }^{55}$.

Atualmente a planta não é muito usada para estes propósitos, mas sim, largamente usada para o tratamento da depressão branda. Dos princípios isolados da planta, os mais importantes são a hipericina, pseudo-hipericina, hiperforina, amentoflavonóide, biapigenina e xantonas. Também estão presentes flavonóides, tais como a rutina, hiperosídeos e óleos essenciais. Outros componentes de importância biológica isolados de diferentes partes da planta são a hiperforina, adhiperforina e 1,3,6,7 tetrahidroxi-xantona dotados de atividade antimicrobiana ${ }^{56}$.

O recente interesse na molécula de HY é o resultado do descobrimento do seu potencial como antiviral, antiretroviral, bactericida, antipsoriático e agente antitumoral além de apresentar alto rendimento quântico do estado triplete e formação do oxigênio singlete ${ }^{57}$. O composto exibe atividade anticancer no escuro, que pode ser aumentada cerca de 100 vezes na presença da luz ${ }^{58}$. Sendo um potente fotossensibilizador, HY é responsável pelo hipericismo, uma fotodermatose 
caracterizada por irritação severa na pele, aumento da temperatura corporal e em alguns casos morte de animais que pastam e comem a planta, como bovinos e ovelhas $^{59}$.

Alguns autores sugerem que $\mathrm{HY}$ é provavelmente o mais poderoso fotossensibilizador encontrado na natureza. Hipericina é um pigmento que produz oxigênio singlete após irradiação com luz com rendimento quântico de $0,73 \pm 0,03$ em etanol ${ }^{59}$. Alguns autores relatam que a HY inibe o crescimento de células derivadas de uma variedade de tecidos neoplásicos como glioma, neuroblastoma, adenoma, mesothelioma, melanoma, carcinoma, sarcoma e leucemia ${ }^{60}$. Embora não seja claro o mecanismo pelo qual a $\mathrm{HY}$ exerce sua atividade biológica, já se sabe que, via oxigênio singlete, ela inibe a atividade da proteína quinase e outras enzimas de defesa celular como a oxidase monoamina e a succinoxidase mitocondrial ${ }^{61}$. A Hipericina foi um dos fotossensibilizadores usados nesse trabalho.

\subsection{Sistemas óticos para a fotossensibilização}

A Terapia Fotodinâmica pode utilizar como fonte de luz lâmpadas de tungstênio ou halogênio, mas geralmente são usados lasers para o tratamento clínico, pois eles podem ser empregados em conjunto com fibras ópticas, facilitando o tratamento de tumores internos. É necessário levar a luz até o local do tumor o que é feito através de sondas ${ }^{62}$. O laser é um amplificador ótico, composto por um meio ativo (sólido, líquido ou gás), que amplifica a luz que o atravessa e uma cavidade ótica que consiste de espelhos especiais que confinam esta amplificação 
de luz. Esses meios ativos apresentam emissão de luz quando excitados por uma fonte externa (elétrica ou ótica). O resultado é a saída de um feixe de radiação eletromagnética intensa, coerente e monocromática ${ }^{63}$. Como a irradiação com laser produz um único comprimento de onda, a potência de saída pode ser medida corretamente, a luz pode ser administrada seletivamente a partes do tumor e, além disso, devido a sua alta intensidade, podem ser utilizadas altas doses de luz reduzindo o tempo de aplicação no paciente. Em cultura de células, a utilização de lasers com altas potências não promove o aquecimento local das células, o que representa uma vantagem adicional. O laser mais utilizado em Terapia Fotodinâmica é o laser de corante bombeado com laser de argônio ${ }^{64}$. Entretanto esses lasers são caros, grandes e requerem a presença de um técnico para aplicação e manutenção. Portanto, as principais desvantagens do laser são o alto custo e as dificuldades operacionais ${ }^{65}$.

Com o emprego de agentes foto-terapêuticos de segunda geração, em virtude de sua elevada absortividade molar, o uso de diodos emissores de luz (LEDLigth Emitting Diode) tem se tornado viável, possibilitando uma redução no custo dos procedimentos (custo em torno de um quarto do preço do laser de corante) e maior facilidade de operação ${ }^{66}$. Ao contrário das lâmpadas alógenas, os LEDs não produzem luz visível através do aquecimento de filamentos metálicos e sim através da combinação de dois semicondutores diferentes ${ }^{67}$. Alguns desses semicondutores possuem excesso de elétrons e outros faltam de elétrons. Os elétrons conectam-se sempre que é aplicada tensão sobre a combinação dos dois tipos de semicondutores. A cor da luz de um LED é determinada pela combinação química da combinação dos semicondutores. Um dos avanços na aplicação da TFD 
é a utilização de LEDs, pois são sistemas mais compactos, o que facilita sua utilização em consultórios médicos ${ }^{68}$.

\subsection{Avaliação da eficiência dos fotossensibilizadores}

\subsubsection{Fotoxidação da albumina bovina}

Várias metodologias são descritas na literatura a fim de comparar os compostos com potencial aplicação em TFD. A fotoxidação de aminoácidos é uma dessas metodologias. Nesse método, acompanha-se a supressão da fluorescência do triptofano devido a sua fotoxidação na presença do FS, sendo que a medida da eficiência fotodinâmica do composto é obtida através da determinação da constante de velocidade da reação ${ }^{69}$

A albumina é a proteína mais abundante no plasma sanguíneo humano, constituindo cerca de $60 \%$ das proteínas do plasma ${ }^{69}$. Nos mamíferos a albumina é sintetizada no fígado, possui uma vida média de 19 dias e é responsável por $80 \%$ da pressão osmótica do sangue. Por ser muito solúvel e de estrutura flexível, inúmeros compostos se ligam reversivelmente à albumina que age como principal proteína transportadora do sistema vascular, transportando inúmeros metabólitos, tais como a bilirrubina, tetrapirroles, ácidos graxos, aminoácidos, pequenos cátions e moléculas exógenas ${ }^{70,71}$.

A albumina de soro bovino (BSA) tem sido utilizada para estudos de interação, pois já foi extensivamente caracterizada e possui função no transporte e armazenamento de compostos nos vertebrados ${ }^{72}$. A proteína BSA contém 582 
resíduos de aminoácidos, possui dois triptofanos nas posições 134 e 212 bem como tirosina e fenilalanina ${ }^{73}$. Este composto possui fluorescência intrínseca devido principalmente aos resíduos de triptofano, podendo emitir luz em cerca de $340 \mathrm{~nm}$ quando excitado por luz de comprimento de onda no ultravioleta por volta de $280 \mathrm{~nm}$. Como a fluorescência intrínseca da proteína geralmente é suprimida pela ligação com os FS, este comportamento espectroscópico fornece uma maneira de se estudar as interações de FSs com a albumina ${ }^{74,75}$. Esse procedimento também tem sido empregado no grupo com o objetivo de comparar a atividade fotodinâmica de fotossensibilizadores ${ }^{76,77,78}$.

\subsubsection{Coeficiente de partição}

Experimentos envolvendo a determinação do coeficiente de partição também são bastante empregados para se avaliar a lipofilicidade de FSs, uma vez que os processos de absorção e distribuição de fármacos são regulados basicamente pela sua hidrofobicidade ${ }^{79}$. O coeficiente de partição é definido como sendo a razão entre as concentrações de uma substância que se estabelecem nas condições de equilíbrio quando dissolvida em um sistema constituído por uma fase orgânica e uma fase aquosa e está associado à mudança de energia livre provocada pela substância sobre o equilíbrio termodinâmico do sistema ${ }^{80}$.

O sistema 1-octanol/tampão fosfato $\mathrm{pH}=7,4$ é considerado o sistema preferencial para a determinação do coeficiente de partição. As principais vantagens do uso do 1-octanol como fase orgânica na determinação do coeficiente de partição são as seguintes: possui ampla capacidade de dissolução frente a diferentes 
compostos químicos; seu grupo hidroxila pode agir como doador ou como receptor de elétrons na formação de ligações de hidrogênio; o octanol tem a capacidade de dissolver até 2,3 mol L ${ }^{-1}$ de água sob condições de equilíbrio; as ligações de hidrogênio de moléculas solvatadas não necessitam ser quebradas durante sua transferência da fase orgânica para a fase aquosa; não é volátil em temperatura ambiente e é quimicamente estável ${ }^{80}$. Essa metodologia será empregada então para fornecer informações sobre a lipofilicidade e será um dos parâmetros na comparação dos FSs estudados.

\subsubsection{Fotoxidação do ácido úrico}

O rendimento quântico de formação de oxigênio singlete $(\Delta \Phi)$ está intimamente relacionado com a eficiência do mecanismo tipo II. Uma maneira indireta de se avaliar o $\Delta \Phi$ é através da eficiência da fotoxidação do ácido úrico pelo FS ${ }^{81}$. No organismo humano, o ácido úrico é encontrado na forma de monoânion urato e a sua concentração no sangue pode chegar a $900 \mu \mathrm{mol} \mathrm{L}^{-1}$ sendo que a concentração normal no plasma é cerca de $300 \mu \mathrm{mol} \mathrm{L} \mathrm{L}^{-1}$. É o produto final do metabolismo da purina e apresenta papel de antioxidante graças à ação dos uratos de reagirem com radicais livres formados em nossas vias metabólicas neutralizando seu efeito danoso ${ }^{82}$. O ácido úrico é um conhecido supressor de oxigênio singlete, podendo ser utilizado como um dosímetro químico para avaliar a eficiência fotodinâmica de substâncias como as porfirinas e seus análogos ${ }^{83}$. Neste método, o coeficiente de atividade fotodinâmica é calculado levando-se em conta o decréscimo 
na absorbância da banda em 293 nm do espectro de absorção ótica do ácido úrico na presença de um FS ativado pela luz ${ }^{84}$.

\subsubsection{Rendimento quântico de fluorescência}

O rendimento quântico de fluorescência $\left(\Phi_{\mathrm{f}}\right)$ e o tempo de vida de fluorescência são as características mais importantes de um fluoróforo ${ }^{85}$, sendo que o rendimento quântico de fluorescência pode ser definido como ${ }^{86}$ :

$$
\Phi_{\mathrm{f}}=\frac{\mathrm{n} . \text { de moléculas fluorescentes por unidadede tempo por unidade de volume }}{\text { n. de quanta absorvido por unidade de tempo por unidade de volume }}
$$

A equação 1 informa a relação entre a quantidade de moléculas que efetivamente fluorescem $\left(n_{F}\right)$ e de moléculas que foram eletronicamente excitadas $\left(\mathrm{N}_{\mathrm{exc}}\right)$ :

$$
\Phi_{\mathrm{f}}=\frac{\mathrm{n}_{\mathrm{F}}}{\mathrm{N}_{\mathrm{exc}}}
$$

O número de moléculas excitadas é, em princípio, equivalente ao número de fótons absorvidos ${ }^{86}$.

A determinação experimental do rendimento quântico necessita de uma correção prévia do espectro de emissão do material ou o uso de um padrão que apresente propriedades semelhantes às da espécie desconhecida, uma delas sendo a do espectro de emissão que deve estar na mesma faixa de emissão do padrão. 
Além disso, alguns interferentes devem ser considerados antes de se iniciar os experimentos, entre eles estão incluídos ${ }^{87}$ :

$\vee$ Efeitos de filtro interno (reabsorção);

$\checkmark$ Efeitos de comprimento de onda, ou seja, grandes diferenças entre o comprimento de onda de absorção e o comprimento de onda de excitação;

v Correções nos índices de refração;

$\vee$ Efeitos de polarização;

$\vee$ Efeitos da temperatura;

$\checkmark$ Efeitos de impurezas;

$\checkmark$ Estabilidade fotoquímica;

$\checkmark$ Espalhamento Raman.

Existem dois métodos comumente usados para a determinação do $\Phi_{\mathrm{f}}$ : métodos primários que incluem o uso de superfícies refletivas como o $\mathrm{BaSO}_{4}$ ou soluções espalhadoras como sílica coloidal para calibrar o sistema de detector/excitação, o uso de actinômetros ou o uso de técnicas calorimétricas; e os métodos secundários que são os mais preferidos experimentalmente e relacionam o rendimento quântico de fluorescência de um padrão com o da amostra de acordo com a equação $3^{87}$ :

$$
\Phi_{\text {famostra }}=\Phi_{\text {fpadrão }} \times\left[\frac{\left(A_{\text {padrão }} \times F_{\text {amostra }} \times n^{2}\right)}{\left(A_{\text {amostra }} \times F_{\text {padrão }} \times n_{0}^{2}\right)}\right]
$$




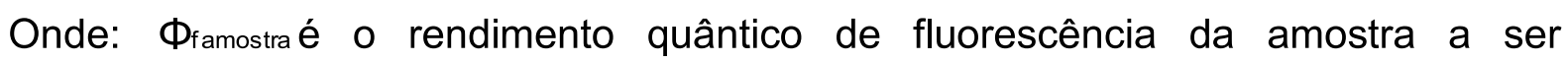
determinado;

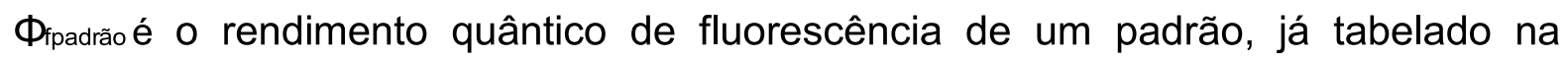
literatura;

A padrão é a absorbância do padrão no comprimento de onda de excitação;

A $_{\text {amostra }}$ é a absorbância da amostra no comprimento de onda de excitação;

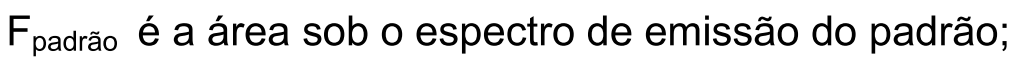

$F_{\text {amostra }}$ é a área sob o espectro de emissão da amostra;

n é o índice de refração do solvente onde se encontra a amostra;

$\mathrm{n}_{0}$ é o índice de refração do solvente onde se encontra o padrão.

As absorbâncias da amostra e do padrão devem ser similares e pequenas, menor que 0,10 , para evitar o efeito filtro ${ }^{88}$.

\subsubsection{Ensaios citotóxicos em cultura celular}

Os ensaios citotóxicos são rotineiramente utilizados por toxicologistas para avaliação de mecanismos tóxicos, e possuem importância devido à seleção de estruturas químicas para triagem farmacológica utilizando células intactas ${ }^{89}$. Para reduzir custos e analisar uma variedade de compostos sintéticos na indústria farmacêutica, os testes in vitro podem ser introduzidos, diminuindo as pesquisas que utilizam animais ${ }^{90}$.

Estudos comparativos de FS envolvendo ensaios citotóxicos em culturas celulares são bastante importantes, pois conseguem fornecer informações que ajudam a melhor predizer o real comportamento in vivo podendo reproduzir de 
forma satisfatória o grande número de possíveis interações que ocorrem em meio biológico ${ }^{91}$. Os primeiros trabalhos com cultura de tecidos de animais datam do início do século $X X$ e tinham a finalidade de estudar o comportamento destes tecidos livres da variação sistêmica, tanto na homeostase normal quanto em condições de estresse ${ }^{92}$. A partir da década de 50 , ocorreu uma aceitação mundial no uso da técnica, sendo que na atualidade encontra-se na fase de especialização, na qual se tenta desvendar os mecanismos de controle da diferenciação celular e da expressão genética $^{93}$.

Cultura de células se refere a culturas derivadas de células dispersas retiradas do tecido original, de uma cultura primária ou de uma linhagem celular já estabelecida em cultura por desagregação enzimática, mecânica ou química ${ }^{94}$.

Os trabalhos com cultura célular muitas vezes utilizam células imortalizadas que podem ser usadas indefinidamente. Existem vários métodos para imortalizar células de mamíferos entre eles a ativação da enzima telomerase ou tranferência de genes virais através do processo conhecido como transformação viral ${ }^{95}$.

Utilizando cultura de células é possível obter a concentração máxima média inibitória $\left(\mathrm{IC}_{50}\right)$ que é uma medida da eficiência de um composto na inibição da função biológica ou bioquímica de um sistema. Esse parâmetro é uma medida quantitativa que indica o quanto de uma determinada substância (inibidor) é necessário para inibir, pela metade, um determinado processo biológico, ou componente de um processo, ou seja, uma enzima, células ou microrganismos ${ }^{96}$. 0 $\mathrm{IC}_{50}$ de uma substância pode ser determinado através da construção de uma curva dose-resposta e análise do efeito de diferentes concentrações da substância no sistema em análise ${ }^{96}$. 


\subsection{Transporte e acumulação dos fotossensibilizadores pelas células}

O transporte do FS até o tecido atingido pelo tumor é feito através de proteínas do sangue. A albumina é a principal proteína do sangue, realiza o transporte de vários metabólitos e moléculas exógenas no sistema circulatório. As lipoproteínas são as responsáveis pela internalização do FS nas células tumorais ${ }^{97}$. Células cancerosas possuem uma elevada concentração de receptores (lipoproteínas de baixa densidade) na membrana citoplasmática. A associação de um FS com a albumina e com a lipoproteína depende do caráter hidrofílico/hidrofóbico do composto ${ }^{98}$.

Os FSs necessitam de um meio líquido para propósitos de injeção ou aplicação tópica. Moléculas anfifílicas e polares podem ser dissolvidas em solventes polares, enquanto FSs hidrofóbicos podem ser administrados em lipossomas fosfolipídicos, cujo transporte é feito com a ajuda de lipoproteínas do plasma. Existe a possibilidade de introduzir substituintes polares nas moléculas do FS a fim de conferir certo grau de anfifilicidade e seletividade. Compostos sulfonados, carboxilados, hidroxilados ou substituídos com sal de amônio quaternário são os mais estudados e interações têm sido observadas em nível molecular, celular e com tecidos do tumor. Observa-se que quanto mais hidrofóbico o FS, maior a sua incorporação pelas células do tumor e melhor o efeito da TFD ${ }^{99}$. Os mecanismos envolvidos na acumulação preferencial dos FS em células tumorais são relatados por uma série de estudos na literatura, apesar disso, esses mecanismos de ação ainda não estão totalmente compreendidos. Algumas possibilidades são consideradas como a especificidade celular, características extracelulares do tumor, 
$\mathrm{pH}$ mais baixo em tecidos tumorais. Além das propriedades dos tecidos, as características físico-químicas do FS devem ser consideradas, como tamanho, carga, estrutura molecular e solubilidade, sendo que os FS mais hidrofóbicos apresentam maior incorporação à bicamada de lipídeos da membrana celular ${ }^{100}$.

Assim, informações sobre acumulação de FSs em células são importantes quando se compara a eficiência fotodinâmica desses compostos.

\subsection{Radicais livres}

\subsubsection{Definição}

Um radical livre é qualquer espécie capaz de existência independente que contenha um ou mais elétrons desemparelhados ${ }^{101}$. As espécies reativas de oxigênio (EROs) incluem todos os radicais do oxigênio, como o ânion radical superóxido, $\mathrm{O}_{2}^{\circ}$, radical hidroxila, $\mathrm{HO}^{\circ}$, radical alquila, $\mathrm{L}^{\circ}$, alcoxila, $\mathrm{LO}^{\circ}$, e peroxila,

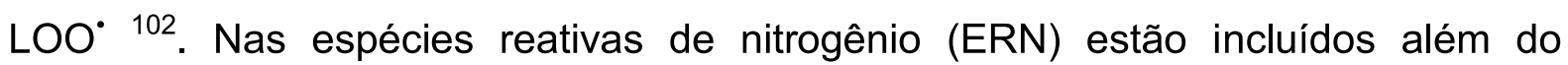
peroxinitrito (ONOO), o óxido nítrico ( $\left.{ }^{\circ} \mathrm{NO}\right)$ e o radical dióxido de nitrogênio $\left({ }^{\circ} \mathrm{NO}_{2}\right)$. O ânion peroxinitrilo (ONOO$)^{-}$, o ácido hipocloroso ( $\left.\mathrm{HOCl}\right)$, o peróxido de hidrogênio $\left(\mathrm{H}_{2} \mathrm{O}_{2}\right)$, o oxigênio singlete $\left({ }^{1} \mathrm{O}_{2}\right)$ e o ozônio $\left(\mathrm{O}_{3}\right)$ não são radicais livres, mas podem induzir reações radicalares, sendo por isso também consideradas como espécies reativas $^{103}$. 


\subsubsection{Detecção de radicais livres}

$\mathrm{Na}$ sua maioria, os radicais são tão reativos que somente existem em soluções extremamente diluídas. Entretanto, mesmo a presença desses radicais reativos pode ser, frequentemente, revelada pelas propriedades magnéticas próprias do elétron não emparelhado ${ }^{104}$.

Um dos primeiros métodos empregados para a detecção de radicais foi através da medida de suscetibilidade magnética ${ }^{105}$. Muitas substâncias são diamagnéticas, isto é, quando colocadas entre os pólos de um poderoso ímã, aparece uma força puxando-as para fora do campo magnético. Esta força é devida ao fato de que todos os elétrons de uma molécula associam-se uns aos outros a fim de se oporem ao campo magnético externo. Substâncias com elétrons não emparelhados, contudo, são paramagnéticas e são atraídas para o campo magnético. Nessas substâncias, a contribuição paramagnética do elétron não emparelhado opõe-se à contribuição diamagnética de todos os elétrons emparelhados. A suscetibilidade magnética das substâncias pode ser medida pela força exercida sobre elas quando estão num campo magnético, usando um dispositivo chamado balança de Gouy ${ }^{106}$.

Em 1945, foi inventada uma técnica que mede diretamente o paramagnetismo de um elétron não emparelhado é a Espectroscopia de Ressonância Paramagnética Eletrônica (RPE), do inglês Electron Paramagnetic Resonance (EPR) é uma técnica que detecta espécies paramagnéticas, isto é, que apresentam elétrons desemparelhados. Ao submeter espécies paramagnéticas a um campo magnético, elas absorvem radiação na freqüência de microondas, 
desencadeando um fenômeno denominado ressonância paramagnética eletrônica. Isso permite a detecção dessas espécies, bem como a determinação de sua concentração ${ }^{107}$.

Uma das características do espectro de RPE é que em alguns casos a posição do acoplamento de linhas (dado especificamente pelos valores de $g$ e constantes hiperfinas) depende da direção do campo magnético relativo aos eixos moleculares. Essa anisotropia espectral não é encontrada em sistemas onde o elétron livre é extensivamente delocalizado e, portanto a anisotropia é pequena, e também porque o movimento de rotação randômico rápido deles é relativamente pequeno. A anisotropia espectral é muito importante na interpretação dos espectros de íons de metais de transição. Cita-se ainda que amostras solubilizadas em solução não viscosa normalmente perdem as características anisotrópicas. Nesse caso, o espectro permanece o mesmo, independente da orientação do campo magnético, valores de $g$ e estrutura do acoplamento hiperfino, são na realidade a média dos valores do eixo principal conhecidos como constante de acoplamento hiperfino isotrópico ${ }^{108}$

As espécies radicalares formadas a partir da interação do FS no estado excitado com oxigênio molecular são os principais responsáveis pelos danos letais causados às células tumorais por TFD. A espectroscopia de ressonância paramagética eletrônica é uma técnica bastante útil para avaliar o envolvimento de oxigênio singlete e de outros intermediários reativos nos processos fotodinâmicos ${ }^{109}$. O 5,5-dimetil-1-pirroline-N-oxide (DMPO) já foi utilizado para avaliar o envolvimento de radicais de oxigênio em células de linfoma após TFD com ftalocianinas de zinco e alumínio. Outros estudos em sistemas modelo utilizaram 
2,2,6,6-tetrametil 1-4-piperidona-N-oxil (TEMPONE) para a determinação do envolvimento de radicais de oxigênio nas reações fotodinâmicas ${ }^{110}$. O DMPO é um "spin trap", ou seja, um captador de spins. O método de captação de spins com DMPO tem sido aplicado com sucesso para captar radicais $\cdot \mathrm{OH}$ e $\mathrm{O}_{2}^{-}$. Após a ligação do captador a um radical primário formado na solução, o radical DMPO/OH, cujo espectro é bastante característico, pode ser detectado por EPR ${ }^{111}$.

A estrutura química do aduto DMPO/OH e o seu espectro estão apresentados na Figura 8.

a)<smiles>CC1(C)CCC(O)N1[O]</smiles>

Figura 8 - a) Fórmula estrutural do 5,5-dimetil-1-pirroline-N-oxide e b) espectro do aduto DMPO/OH com constante de acoplamento hiperfino de $a_{N}=a_{H}=14,9 \mathrm{G}^{111}$.

As metodologias empregadas nesse trabalho visam fazer uma comparação da atividade fotodinâmica entre o Photogem, o único fotossensibilizador aprovado pela Agência Nacional de Vigilância Sanitária (ANVISA), é uma agência reguladora vinculada ao Ministério da Saúde do Brasil, Photodithazine e a Hipericina, considerada por inúmeros autores como um dos mais poderosos fotossensibilizadores encontrados na natureza. Além disso, verificar a acumulação em diferentes tempos de incubação em células de mamíferos, relacionando com o efeito fototóxico. E por fim determinar os radicais livres formados após irradiação com luz de comprimento de onda utilizado nos ensaios de fototoxicidade. 


\section{OBJETIVOS}

O objetivo deste trabalho foi realizar um estudo comparativo entre Hipericina, Photodithazine e Photogem, através da obtenção dos seguintes parâmetros:

i. concentração inibitória média $\left(I_{50}\right)$ na presença e ausência de luz em células tumorais e células normais;

ii. coeficiente de partição em octanol-água (log P) para acessar a hidrofobicidade dos fotossensibilizadores;

iii. constantes de velocidade de fotoxidação da proteína (BSA) na presença dos fotossensibilizadores;

iv. eficiência fotodinâmica obtida pelo uso do ácido úrico como dosímetro químico que captura o oxigênio singlete formado quando os FSs são irradiados;

v. determinação do rendimento quântico de fluorescência;

vi. acumulação dos FSs em células HEp-2 e Vero;

vii. formação de radicais livres após irradiação dos FSs acompanhada pela técnica de spin trapping-RPE. 


\section{MATERIAIS E MÉTODOS}

\subsection{Reagentes e equipamentos}

A Hipericina utilizada foi sintetizada pelo Prof. Dr. Anderson O. Ribeiro da Universidade Federal do ABC e caracterizada por Ressonância Magnética Nuclear (RMN). A solução estoque de concentração $1 \mathrm{mg} \mathrm{mL}^{-1}$ foi obtida em solvente aprótico polar, dimetil sulfóxido (DMSO), esterilizada por filtração em membrana com poro de $0,22 \mu \mathrm{m}$ e mantida ao abrigo da luz a $4{ }^{\circ} \mathrm{C}$.

Photogem $^{\circledR}$ foi obtido da Photogem LLC Company (Moscou, Rússia) e Photodithazine ${ }^{\circledR}$ foi fornecido pelo Institute of Biomedical Chemistry of the Russian Academy of Medical Sciences of Moscou. Ambos os FSs foram cedidos pelo Prof. Dr. Vanderlei S. Bagnato (IFSC-USP), coordenador do Centro de Pesquisa, Inovação e Difusão de Ótica e Fotônica (CEPOF) criado pela FAPESP e do qual o grupo de Fotossensibilizadores do IQSC faz parte. As soluções estoque de PG e PZ foram preparadas em solução salina tamponada com fosfato (PBS) $\mathrm{pH}=7,4$ esterilizadas por filtração em membrana de 0,22 $\mu \mathrm{m}$ e mantidas ao abrigo da luz a $4{ }^{\circ} \mathrm{C}$

Todos os solventes utilizados foram de grau analítico e ou grau espectroscópico e a água foi obtida no Milli-Q Plus (Millipore).

As medidas de absorção ótica foram realizadas no espectrofotômetro HITACHI U-2800 e as de fluorescência foram realizadas em espectrofluorímetro HITACHI F-4500. As cubetas utilizadas para as medidas eram espectroscópicas de quartzo com caminho ótico de $1 \mathrm{~cm}$. 
Um leitor de placas modelo Benchmark (BIO-RAD) com filtro em $550 \mathrm{~nm}$ foi empregado para a leitura da absorbância das células em placas de 96 poços para a contagem celular nos ensaios citotóxicos.

A espectroscopia de RPE, mais especificamente a técnica spin trapping, foi utilizada para determinar a formação de radicais livres após irradiação dos FSs. Os espectros foram obtidos em espectrofotômetro E109 da Varian, com $100 \mathrm{kHz}$ de modulação, freqüência de operação $9 \mathrm{GHz}$ e temperatura ambiente, no laboratório de Biofísica do Instituto de Física de São Carlos da Universidade de São Paulo/USP.

\subsection{Sistemas óticos para a fotossensibilização}

As fontes de luz utilizadas, chamadas de Biotables são constituídas de um conjunto de LEDs com emissão em $590 \pm 11$ nm (amarelo) e em $630 \pm 10$ nm (vermelho), ambos mostrados na Figura 9, com intensidades médias por área igual a $18 \mathrm{~mW} \mathrm{~cm}^{-2}$ e $10 \mathrm{~mW} \mathrm{~cm}^{-2}$, respectivamente. Esses aparelhos são refrigerados à água e foram desenvolvidos especialmente para irradiação de células em cultura pelo Laboratório de Apoio Técnico do IFSC-USP, também parte do CEPOF e cedidos pelo Prof. Dr. Vanderlei S. Bagnato. 
a)

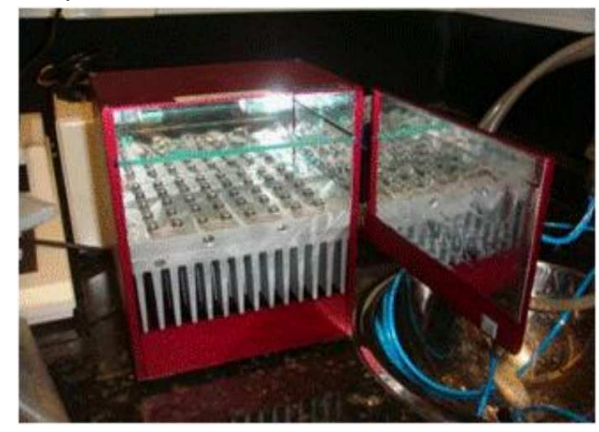

b)

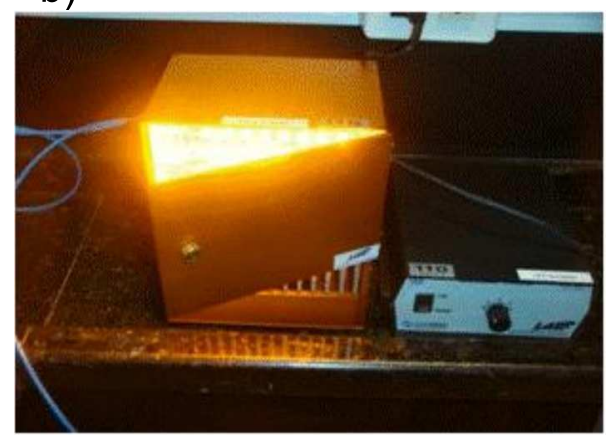

Figura 9 - Fontes de luz utilizadas: a) LED com emissão em $630 \pm 10 \mathrm{~nm}$ e b) LED com emissão em $590 \pm 11 \mathrm{~nm}$.

\subsection{Cultura celular}

Nos ensaios citotóxicos foram utilizadas as linhagens de células epiteliais de carcinoma epidermóide de laringe humana, HEp- 2 (ATCC CCL-23), de rim de macaco verde africano, Vero (ATCC CCL-81), de músculo de camundongo, McCoy (ATCC CRL-1696) e de melanoma de camundongo B16-F10 (ATCC CRL-6475) ${ }^{112}$.

Devido as suas morfologias, essas linhagens foram cultivadas aderidas a um substrato sólido, ou seja, garrafas de vidro ou de polipropileno, em meio de cultura Dulbecco modificado por Iscove com $10 \%$ de soro fetal bovino (SFB) e antibióticos penicilina 10000 U.I. mL ${ }^{-1}$ e estreptomicina $10 \mathrm{mg} \mathrm{mL}^{-1}$. As células foram mantidas em estufa a $37{ }^{\circ} \mathrm{C}, 95 \%$ de ar e $5 \%$ de $\mathrm{CO}_{2}$ gasoso ${ }^{113,114}$ Todas as manipulações celulares foram realizadas em ambiente estéril, numa capela de fluxo laminar, com materiais esterilizados, a fim de se evitar contaminação celular ${ }^{115}$.

O subcultivo das células foi feito a cada três dias removendo-se o meio de cultura seguido de adição de solução salina tamponada com fosfato (PBS) pH=7,4 para retirar o resto de meio de cultura e adição da enzima proteolítica tripsina com 
0,03\% de etilenodiaminotetracético (EDTA) para digerir as proteínas na matriz extracelular, uma vez que é um agente quelante que liga ou quela o $\mathrm{Ca}^{2+}$ do qual depende a adesão entre as células. A tripsina pode ser prejudicial às células, portanto meio de cultura foi adicionado logo após a desagregação das células a fim de inativar a tripsina. A seguir as células foram transferidas para um tubo cônico e centrifugadas a $1000 \mathrm{rpm}$ durante $1 \mathrm{~min}$, descartou-se o sobrenadante para posterior ressuspensão das células em meio de cultura ${ }^{113}$.

Após homogeneização das células em meio de cultura, retirou-se uma alíquota para a contagem do número de células. As células foram contadas em hemocitômetro e distribuídas em frascos de cultura ou placas apropriadas para os ensaios citotóxicos e de acumulação, conforme a concentração celular desejada ${ }^{112}$.

Para a determinação da viabilidade celular utilizou-se o método da contagem em câmara de Newbauer através do teste de exclusão do corante. O "trypan blue" é um corante que é incorporado seletivamente pelas células mortas nas quais a integridade da membrana celular é danificada (rompida). Para isso foi retirada uma alíquota de $100 \mu \mathrm{L}$ da suspensão celular, $400 \mu \mathrm{L}$ de PBS, como diluente, e $500 \mu \mathrm{L}$ de solução 0,4 \% de "trypan blue". Retirou-se uma alíquota da suspensão celular e diluiu-se 100 vezes, preparou-se a câmara de Newbauer colocando-se a lamínula de maneira adequada para que o espaço para a suspensão não ficasse maior que o necessário. As células de todos os quadrantes foram contadas e fez-se uma média dos valores obtidos. Essa média foi multiplicada por $10^{4}$ e pelo fator de diluição 10 obtendo-se desta forma o número de células por $\mathrm{mL}$ de suspensão ${ }^{113}$.

Para a determinação da viabilidade, calculou-se separadamente o número de células vivas e mortas, levando-se em conta que as células vivas 
apresentam-se incolores ao microscópio, enquanto que as células mortas apresentam uma coloração violeta devido à incorporação do corante. Calculou-se a viabilidade celular em porcentagem (\%) através da seguinte relação:

$$
\% \text { Viabilidade }=\frac{\text { número de células não coradas } \times 100}{\text { número total de células }}
$$

Para a preservação das células instáveis em culturas bem como para a manutenção de um estoque de células que pode vir a ser utilizado por longos períodos e também em casos de uma eventual contaminação, o congelamento de um estoque de células é fundamental. Desta forma utiliza-se a técnica da criopreservação, que consiste na estocagem de células a temperaturas muito baixas de modo a inibir qualquer atividade enzimática.

Os crioprotetores são substâncias utilizadas para prevenir danos às células durante o processo de congelamento, devido principalmente ao crescimento de cristais de gelo e às trocas osmóticas. O DMSO e o glicerol são dois tipos de crioprotetores bastante utilizados, mas nesse trabalho foi utilizado o DMSO ${ }^{114}$.

Para o congelamento, remove-se as células do frasco de cultura e prepara-se uma suspensão no intervalo de concentração de 2-6 x $10^{6}$ células $\mathrm{mL}^{-1}$ em meio de cultura contendo $10 \%$ de SFB e $10 \%$ de DMSO. A seguir as células são aliquotadas em frascos criogênicos apropriados e armazenados em nitrogênio líquido à $-196{ }^{\circ} \mathrm{C}$ ou congelador $\mathrm{a}-80{ }^{\circ} \mathrm{C}{ }^{113}$.

O descongelamento das células é feito quando se necessita de células para o cultivo. Para o descongelamento, retiram-se os frascos com células do tambor de criogenia ou do freezer $-80^{\circ} \mathrm{C}$, faz-se a homogeneização de seu conteúdo que é 
transferido para uma garrafa de cultura contendo meio de cultura com $10 \%$ de SFB e procede-se conforme descrito anteriormente ${ }^{113}$.

\subsection{Ensaios citotóxicos}

Para os experimentos citotóxicos foram plaqueadas, em placas de cultura de 96 poços, $1 \times 10^{5}$ células $\mathrm{mL}^{-1}$ em meio de cultura e incubadas a $37^{\circ} \mathrm{C}$ e $5 \%$ de $\mathrm{CO}_{2}$ gasoso. Após $24 \mathrm{~h}$, removeu-se o meio por aspiração e "lavou-se" a monocamada de células com PBS. As células foram então incubadas com diferentes faixas de concentração de cada fotossensibilizador por até $24 \mathrm{~h}$. Após esse período de incubação, retirou-se o meio contendo o FS, "lavou-se" as células com PBS, adicionou-se meio de cultura e irradiaram-se as placas com LED de comprimento de onda adequado por diferentes intervalos de tempo. Experimentos controle foram feitos paralelamente para verificar a citotoxicidade intrínseca dos FS, ou seja, não irradiados. Após a irradiação as células foram mantidas em estufa de cultura por $48 \mathrm{~h}$. Esse intervalo é considerado ideal para o encerramento de ensaios de sobrevivência após tratamento fotodinâmico, já que tempos de incubação menores podem não permitir que as células se recuperem totalmente do tratamento a que foram submetidas e intervalos maiores podem acarretar um aumento muito grande no número de células dificultando a contagem ${ }^{116}$. 


\subsection{Contagem do número de células}

Após o período de recuperação as células foram tratadas com 3-4,5dimetiltiazol-2-il-2,5-difenil brometo de tetrazolio (MTT). Este método de contagem de células baseia-se na redução do MTT, um composto amarelo que é reduzido a um produto chamado formazan, de coloração violeta que absorve em $570 \mathrm{~nm}$. A redução é feita pelas desidrogenases mitocondriais presentes somente nas células vivas. Após $3 \mathrm{~h}$ de incubação o meio com MTT é retirado, tendo cuidado para não danificar os cristais de formazam formados e $50 \mu \mathrm{L}$ de álcool etílico é adicionado. Após diluição completa dos cristais, adiciona-se $150 \mu \mathrm{L}$ de uma mistura de PBS com álcool isopropílico na proporção 1:1. A absorbância proveniente da solução resultante de cada poço da placa é lida em leitor de placas com filtro em $550 \mathrm{~nm}$ 117, 118 . Para obter o valor da concentração inibitória média $\left(\mathrm{IC}_{50}\right)$, que representa a concentração da droga capaz de matar $50 \%$ da população de células, utilizou-se o programa CalcuSyn ${ }^{119}$.

\subsection{Fotoxidação dos aminoácidos com albumina de soro bovino}

Este experimento foi empregado para investigar a eficiência de cada FS em causar a fotoxidação de proteínas, utilizando como modelo a albumina de soro bovino. A eficiência fotodinâmica foi estimada com base na determinação dos valores das constantes de velocidade de fotoxidação da molécula de BSA.

Uma solução contendo $1 \mu \mathrm{g} \mathrm{mL}^{-1}$ de FS e $130 \mu \mathrm{g} \mathrm{mL}^{-1}$ de BSA preparada em tampão fosfato $(\mathrm{pH}=7,4)$ foi irradiada por até 60 min com LED $630 \mathrm{~nm}$, 
$\mathrm{I}=18 \mathrm{~mW} \mathrm{~cm}{ }^{-2}$. A cada $5 \mathrm{~min}$ uma alíquota foi retirada e a fotoxidação da BSA foi acompanhada através da variação da intensidade do máximo de fluorescência em $340 \mathrm{~nm}$, sendo utilizado o comprimento de onda de $279 \mathrm{~nm}$ para excitar a molécula.

Em geral a fotoxidação de biomoléculas ocorre via oxigênio singlete, ou seja, pelo mecanismo tipo II que pode ser representado pelas seguintes equações ${ }^{120}$ :

$$
\begin{aligned}
& { }^{0} \mathrm{P} \stackrel{{ }^{\mathrm{hv}}}{\longrightarrow}{ }^{1} \mathrm{P} \stackrel{\text { cints }}{\longrightarrow}{ }^{3} \mathrm{P} \\
& { }^{3} \mathrm{P}+{ }^{3} \mathrm{O}_{2} \longrightarrow{ }^{0} \mathrm{P}+{ }^{1} \mathrm{O}_{2} \quad \mathrm{k}_{1} \\
& { }^{1} \mathrm{O}_{2}+\mathrm{S} \longrightarrow \text { Produto fotoxidado } \mathrm{k}_{2}
\end{aligned}
$$

onde:

${ }^{0} \mathrm{P}=\mathrm{FS}$ no estado singlete fundamental

${ }^{1} \mathrm{P}=\mathrm{FS}$ no estado singlete excitado

${ }^{3} \mathrm{P}=\mathrm{FS}$ no estado triplete excitado

${ }^{1} \mathrm{O}_{2}=$ oxigênio singlete

${ }^{3} \mathrm{O}_{2}=$ oxigênio triplete

$\mathrm{S}=$ substrato

Se a equação 7 for a etapa mais lenta, esta etapa será a determinante da velocidade da reação ${ }^{121,122}$, então:

$$
\mathrm{d}[\mathrm{S}] / \mathrm{dt}=-\mathrm{k}_{2}\left[{ }^{1} \mathrm{O}_{2}\right][\mathrm{S}]
$$

$\mathrm{A}\left[{ }^{1} \mathrm{O}_{2}\right]$ é diretamente proporcional à concentração do $\left[{ }^{3} \mathrm{O}_{2}\right]$. Pela lei de Henry, estimou-se que em meio aquoso a $\left[{ }^{3} \mathrm{O}_{2}\right]$ é igual a $2,6 \mathrm{~mol} \mathrm{~L}^{-1}{ }^{123}$. Extrapolando para um meio micelar pode-se considerar que a concentração de $\left[{ }^{3} \mathrm{O}_{2}\right]$ é muito maior que 
a concentração do FS, portanto pode-se considerar a $\left[{ }^{1} \mathrm{O}_{2}\right]$ como sendo constante. Portanto, a equação 8 relaciona apenas a [S]:

$$
\mathrm{d}[\mathrm{S}] / \mathrm{dt} \approx-\mathrm{k}[\mathrm{S}]
$$

cuja forma integrada é:

$$
\ln \left([S] /\left[S_{0}\right]\right)=-k t
$$

onde:

[S] = concentração do substrato (BSA) num dado momento

$\left[\mathrm{S}_{0}\right]=$ concentração inicial do substrato, $\mathrm{t}=0$

$\mathrm{t}=$ tempo

$\mathrm{k}=\mathrm{a}$ constante de velocidade da reação de fotoxidação

Como a concentração do substrato $(S)$ é proporcional à intensidade de fluorescência (IF), pode-se reescrever a equação 10 como:

$$
\ln (\mathrm{IF} / \mathrm{IF})_{0}=-\mathrm{k} \mathrm{t}
$$

onde $\mathrm{IF}_{0}=$ intensidade de fluorescência quando $\mathrm{t}=0$.

A equação 11 indica que a cinética global é de pseudo-primeira ordem, pois o gráfico de In ([S] / [S $]$ em função do tempo é uma reta cujo coeficiente angular é -k e corresponde à constante de velocidade de fotoxidação. Portanto, quanto maior a 
constante de velocidade determinada por este método, mais eficientemente o FS fotooxida proteínas, o que é uma medida da formação de oxigênio singlete.

\subsection{Determinação dos coeficientes de partição dos fotossensibilizadores}

O logaritmo do coeficiente de partição foi utilizado como uma medida do caráter lipofílico dos FS, calculado de acordo com o método proposto por Pooler e Valenzeno $^{124}$

A solução de PBS e o 1-octanol foram utilizados como solventes imiscíveis, cada um pré-saturado com o outro. Foram preparadas soluções de $10 \mu \mathrm{g} \mathrm{mL}^{-1}$ dos FSs em PBS, obteve-se o espectro de absorbância, transferiu-se $10 \mathrm{~mL}$ de cada solução de FS com igual volume de 1-octanol para um recipiente com agitação constante por $1 \mathrm{~h}$ para promover a partição do FS entre a fase aquosa e orgânica. Deixou-se em repouso por $24 \mathrm{~h}$ para a separação das duas fases. As concentrações dos FSs antes e após a partição foram obtidas espectrofotometricamente nos comprimentos de onda do máximo da banda de absorção de cada FS. O logaritmo do coeficiente de partição, log $\mathrm{P}$, foi calculado de acordo com a seguinte equação:

$$
\log P=\left[\frac{\left(A b s_{A}\right)}{\left(A b S_{D}\right)}-1\right] \frac{V_{P B S}}{V_{\text {oct }}}
$$

sendo:

$\log P=\log a r i t m o$ do coeficiente de partição

$\operatorname{Abs}_{\mathrm{A}}=$ absorção ótica da solução antes da partição

Abs $D_{D}=$ absorção ótica da solução após a partição 


$$
\begin{aligned}
& V_{\text {PBS }}=\text { volume de PBS em } \mathrm{mL} \\
& V_{\text {oct }}=\text { volume de 1-octanol em } \mathrm{mL}
\end{aligned}
$$

Segundo Kepczynski et al. ${ }^{125}$, se $\log \mathrm{P}<0$, o composto tem um caráter hidrofílico, se lo $P>1,5$, o caráter é lipofílico e se $0<\log P<1,5$ a substância tem um caráter anfifílico.

\subsection{Fotoxidação do ácido úrico}

O ácido úrico foi utilizado como dosímetro químico para se calcular o coeficiente de atividade fotodinâmica (AF) dos FSs segundo o procedimento padrão descrito por Fischer et al $^{81}$.

Foram preparadas soluções de FS, $5 \mu \mathrm{g} \mathrm{mL}^{-1}$ e ácido úrico $10 \mu \mathrm{g} \mathrm{mL}^{-1} \mathrm{em}$ SDS $2 \%$ que foram misturadas e tiveram o espectro de absorção obtido. Em seguida, esta solução foi submetida à irradiação no LED vermelho, $\mathrm{l}=18 \mathrm{~mW} \mathrm{~cm} \mathrm{~cm}^{-2}$ por 5 min, sob agitação.

Após a irradiação, obteve-se novo espectro de absorbância a fim de determinar a absorção do ácido úrico em 293 nm. O decréscimo na intensidade da banda em 293 nm decorrente da reação de fotoxidação da molécula de ácido úrico pelo oxigênio singlete foi utilizado para calcular o coeficiente de atividade fotodinâmica, segundo a equação 13:

$$
\mathrm{AF}=\frac{\Delta \mathrm{A}_{\mathrm{AU}} \times 10^{5}}{\mathrm{P} \times \mathrm{t} \times \mathrm{A}\left(\lambda_{\text {irra }}\right)}
$$


Onde:

$A F=$ atividade fotodinâmica $\left(\mathrm{m}^{2} \mathrm{~W}^{-1} \mathrm{~s}^{-1}=\mathrm{m}^{2} \mathrm{~J}^{-1}\right)$

$\Delta \mathrm{A}_{\mathrm{AU}}=$ variação da intensidade da absorção do ácido úrico em $293 \mathrm{~nm}$, antes e após

a irradiação

$\mathrm{P}=$ potência da luz $\mathrm{W} \mathrm{m}^{-2}$

$\mathrm{t}=$ tempo de irradiação $(\mathrm{s})$

$\mathrm{A}\left(\Lambda_{\text {irra }}\right)=$ absorbância do FS na mistura $\mathrm{FS}+\mathrm{AU}$ no comprimento de onda da irradiação do LED

\subsection{Rendimento quântico de fluorescência dos FSs}

Para a determinação dos rendimentos quânticos de fluorescência dos FSs foi utilizado o método que relaciona o rendimento quântico de fluorescência de um padrão com o da amostra. Os FSs e o padrão utilizado, rodamina $B\left(\Phi_{f}=0,65\right.$ em

etanol ${ }^{88}$ ), foram solubilizados em álcool etílico de grau espectroscópico. Devido à alta hidrofobicidade da HY é esperado que o processo de auto-agregação ocorra em meio aquoso. O solvente aquoso apresenta características que induzem o processo de auto-agregação, tais como o potencial para formar ligações de hidrogênio. Este processo de agregação tende a ser intensificado, originando uma supressão de fluorescência. Assim, usar um solvente que alia ligações hidrogênio de um lado e cadeia alquílica de outro como etanol que atua de maneira semelhante aos surfactantes, favorece a solubilidade ${ }^{126}$. Certificou-se que os valores das absorbâncias das soluções empregadas tanto de FSs quanto de rodamina B sempre fossem menores que 0,10 para evitar o efeito filtro interno. 


\subsection{Acumulação de fotossensibilizadores em células HEp-2 e Vero}

Esses experimentos foram realizados para comparar as diferenças de acumulação dos FSs em linhagem tumoral e não tumoral verificando-se a concentração do FS que foi acumulada em cada linhagem celular em função do tempo de incubação. Ensaios de citotoxicidade foram feitos paralelamente a fim de se obter o tempo máximo de incubação necessário.

As concentrações de cada FS foram normalizadas pela concentração de proteína na amostra que é diretamente proporcional ao número de células. Para isso, a proteína total foi determinada pelo método de Lowry que utiliza o reagente de Folin-Cioucalteau que se liga a aminoácidos aromáticos em tartarato de cobre alcalino resultando em uma coloração azul ${ }^{127}$.

Medindo-se a absorbância de concentrações conhecidas de BSA obteve-se um gráfico de absorbância em função da concentração de BSA $\left(0,02-0,2 \mathrm{mg} \mathrm{mL}^{-1}\right)$. A relação é linear e assim é possível, através da equação da reta estimar a concentração proteica a partir da absorbância em $750 \mathrm{~nm}$. Foram obtidas também curvas padrão dos FSs em SDS 2\%, que foi adicionado à solução de HY para solubilizar completamente a Hipericina ${ }^{128}$.

Em placas de Petri de $60 \mathrm{~mm}$ de diâmetro incubou-se $5 \mathrm{~mL}$ uma suspensão contendo de $1 \times 10^{5}$ células $\mathrm{mL}^{-1}$. Após $24 \mathrm{~h}$ o meio foi retirado e adicionou-se $10 \mu \mathrm{gL}^{-1}$ de FS solubilizado em meio de cultura e após determinados intervalos de tempo de incubação retirou-se o meio com o FS, lavou-se a monocamada celular com PBS, adicionou-se $1 \mathrm{~mL}$ de tripsina/EDTA, aguardou-se cerca de $1 \mathrm{~min}$, transferiu-se a suspensão celular para um tubo cônico, centrifugou-se por 1 min a 
$1000 \mathrm{rpm}$ e retirou-se o sobrenadante. Adicionou-se $1 \mathrm{~mL}$ de PBS ao sedimento agitou-se levemente o tubo e centrifugou-se. Esse procedimento foi repetido mais uma vez. A seguir, adicionou-se $500 \mu \mathrm{L}$ de PBS e resuspendeu-se o sedimento tirou-se uma alíquota de $100 \mu \mathrm{L}$ para a determinação de proteína e centrifugou-se o restante, retirou-se o sobrenadante adicionou-se $1 \mathrm{~mL}$ de SDS $2 \%$ para extrair o FS. Após leve agitação aguardou-se $1 \mathrm{~h}$ e fez-se nova centrifugação por $1 \mathrm{~min}$ a 1000 rpm, em seguida fez-se a leitura de fluorescência ${ }^{99}$.

Dessa forma, pode-se obter a concentração intracelular de cada FS normalizada pela concentração de proteína.

\subsection{Determinação dos radicais livres por spin trapping}

A espectroscopia de ressonância paramagnética eletrônica, mais especificamente a técnica de captura de spins, foi utilizada para determinar a formação de radicais livres após irradiação dos FSs ${ }^{128,129}$. Os experimentos foram realizados em colaboração com o Prof. Dr. Otaciro Rangel Nascimento (IFSC-USP) e a Dra. Tania T. Tominaga (UNICENTRO) da seguinte maneira: soluções de $50 \mu \mathrm{g} \mathrm{mL}^{-1}$ dos FSs HY em DMSO, PG e PZ em PBS juntamente com 0,5 mol L ${ }^{-1}$ de 5,5-dimetil-1-pirrol-N-óxido (DMPO) foram transferidas para uma cubeta de quartzo específica para RPE e irradiadas, pó até 25 min diretamente na cavidade do RPE 130, 131 com um LED $630 \mathrm{~nm}$ e I= $10 \mathrm{~mW} \mathrm{~cm}^{-2}$ (Lumiled), pertencente ao Laboratório de Biofísica do IFSC-USP. 


\subsection{Cálculo da média amostral e do desvio padrão e análise estatística dos} dados experimentais

Os valores experimentais foram expressos como média \pm desvio padrão, os cálculos foram realizados segundo as equações abaixo ${ }^{132}$ :

$$
\overline{X i}=\frac{\sum_{i=1}^{n} x i}{n}
$$

$$
S j=\sqrt{\frac{\sum_{i=1}^{n}(X i-\overline{X j})^{2}}{n-1}}
$$

Sendo:

$\overline{\mathrm{Xi}}=$ média amostral

Xi = i-ésima observação

n = número total de observações

Sj = estimativa do desvio padrão

O número de experimentos é dado na legenda de cada figura. A análise estatística dos valores experimentais foi feita utilizando-se o test-t de Student para mostrar a significância da diferença entre pares de médias. O nível de significância é de $p<0,05$ para todas as análises estatísticas. Todos os tratamentos estatísticos foram realizados no programa Origin Reference V8. 


\subsection{Descarte dos resíduos gerados nos experimentos}

Os resíduos líquidos gerados em todos os experimentos com células foram descartados após tratamento com solução de hipoclorito de sódio $3 \%$ durante $1 \mathrm{~h}$ ou esterilizados em autoclave à $120^{\circ} \mathrm{C}$ por $30 \mathrm{~min}{ }^{115}$. Os resíduos provenientes dos ensaios para determinação do coeficiente de partição, bem como soluções de ácidos para lavagem de vidrarias em geral, foram encaminhados ao Laboratório de Resíduos Químicos do Campus da USP - São Carlos. 


\section{RESULTADOS E DISCUSSÕES}

\subsection{Espectros de absorção ótica dos fotossensibilizadores}

A Hipericina é moderadamente solúvel em vários solventes. Na maioria dos solventes orgânicos origina uma solução vermelha; em meio básico a solução apresenta a coloração verde e em meio aquoso uma dispersão violeta com finas partículas. O espectro de absorção ótica em PBS apresenta duas bandas em $564 \mathrm{~nm}$ e $606 \mathrm{~nm}$ e duas bandas na região do ultravioleta ${ }^{133}$. Os espectros de absorção ótica da Hipericina em PBS e em DMSO estão apresentados na Figura 10.
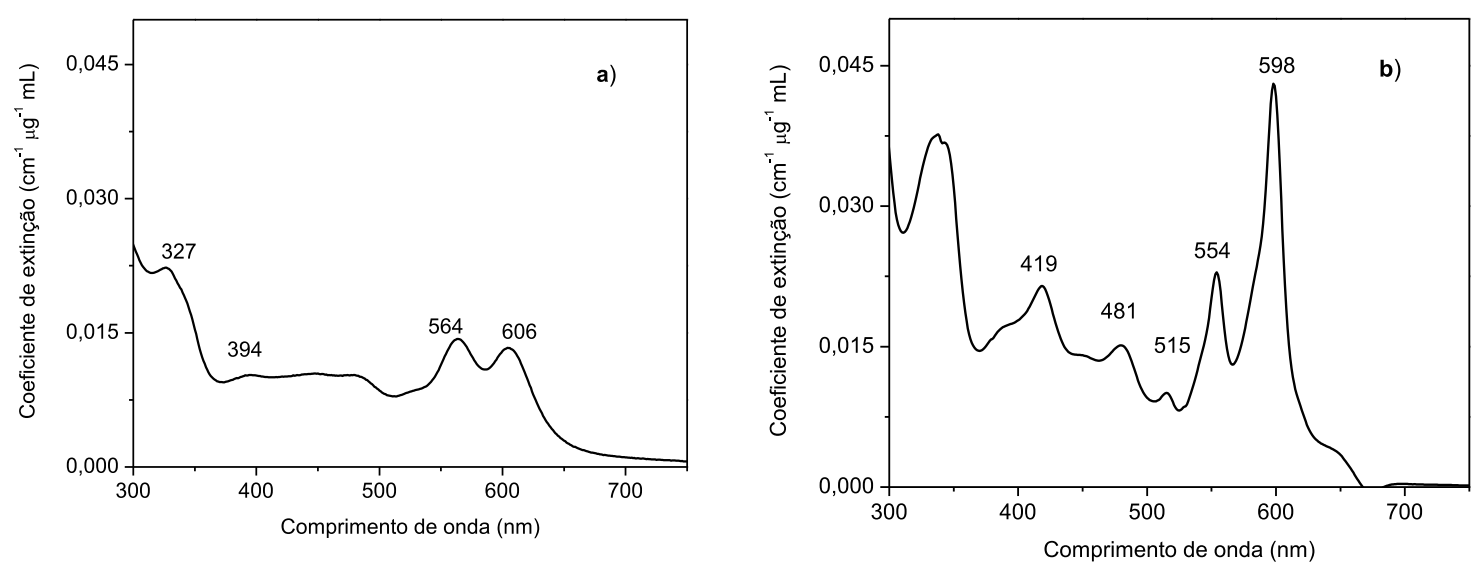

Figura 10 - Espectros de absorção ótica da $\mathrm{HY} 15 \mu \mathrm{g} \mathrm{mL}{ }^{-1}$, a) em PBS, $\mathrm{pH}=7,4$, b) em DMSO.

Observa-se uma drástica diferença entre os espectros da HY obtidos em PBS e DMSO, que incluem a intensidade dos picos, a largura e o deslocamento das bandas. Yamazaki et al. ${ }^{134}$ relatou a estrutura monomérica e agregados de forma indeterminada da HY em uma vasta série de solventes orgânicos e em solução aquosa. Em água, a HY se dissolve com moderação, mas torna-se solúvel em pH acima de 8. Sabe-se que a presença de agregados em soluções de FSs altera os 
espectros de absorção e fluorescência, causando deslocamento nas bandas e desvios na lei de Beer. A presença de agregados pode modificar as propriedades fotofísicas de uma substância, diminuindo a sua habilidade de fotossesibilizador ${ }^{134}$.

Photogem apresenta um espectro de absorção ótica característico dos derivados de hematoporfirinas, uma banda de Soret com máximo de absorção em $367 \mathrm{~nm}$ e quatro bandas Q com máximos em 506, 539, 570 e $620 \mathrm{~nm}$ e está apresentado na Figura 11.

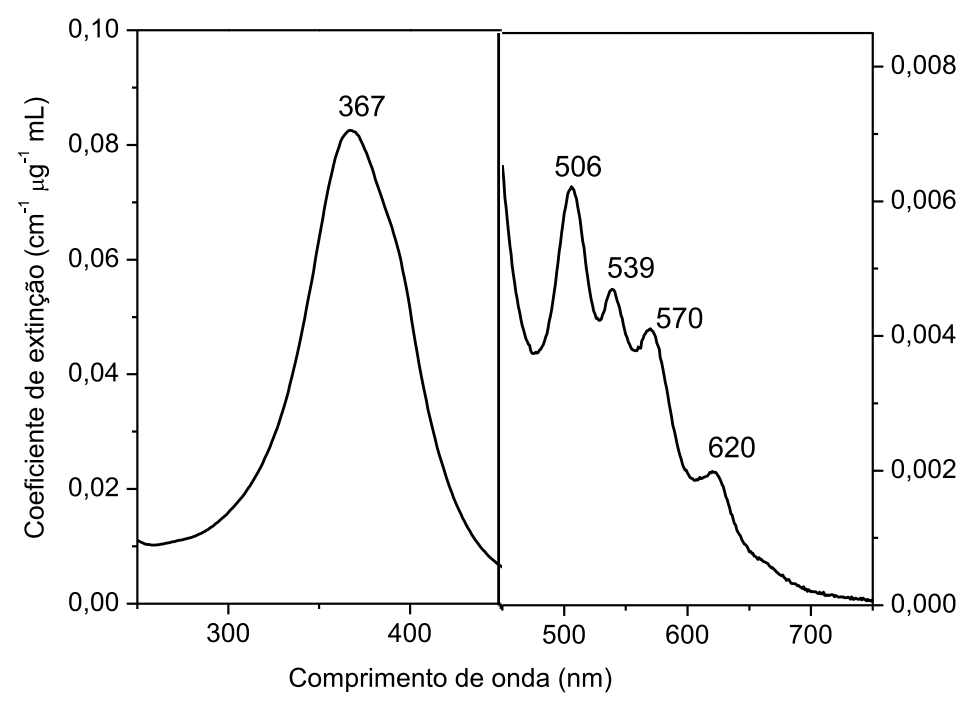

Figura 11 - Espectro de absorção ótica do PG $15 \mu \mathrm{g} \mathrm{mL} \mathrm{L}^{-1}$, em PBS, $\mathrm{pH}=7,4$.

Os espectros de absorção das porfirinas não metaladas diferenciam-se das metaladas por apresentarem quatro bandas $Q$ ao invés duas bandas. As porfirinas não metaladas apresentam distorções na sua estrutura principal, ou seja, no conjunto de anéis pirrólicos, ocasionando uma diferença de 25 a $29 \mathrm{~kJ} \mathrm{~mol}^{-1}$ entre os níveis de energia, e conseqüentemente, o aumento do número de bandas $Q$. As clorinas são porfirinas reduzidas, hidrofílicas com forte absorção entre 640-700 nm. 
A hidrogenação de uma ou mais duplas ligações pirrólicas produz uma dramática mudança no anel pirrólico: um considerável deslocamento para o vermelho e um aumento da intensidade no comprimento de onda de maior absorção ${ }^{135}$.

O Photodithazine apresenta bandas características de clorina, ou seja, banda de Soret com máximo de absorção em 399 nm e três bandas Q com máximos em 505, 625 e 656 nm, como apresentado na Figura 12.

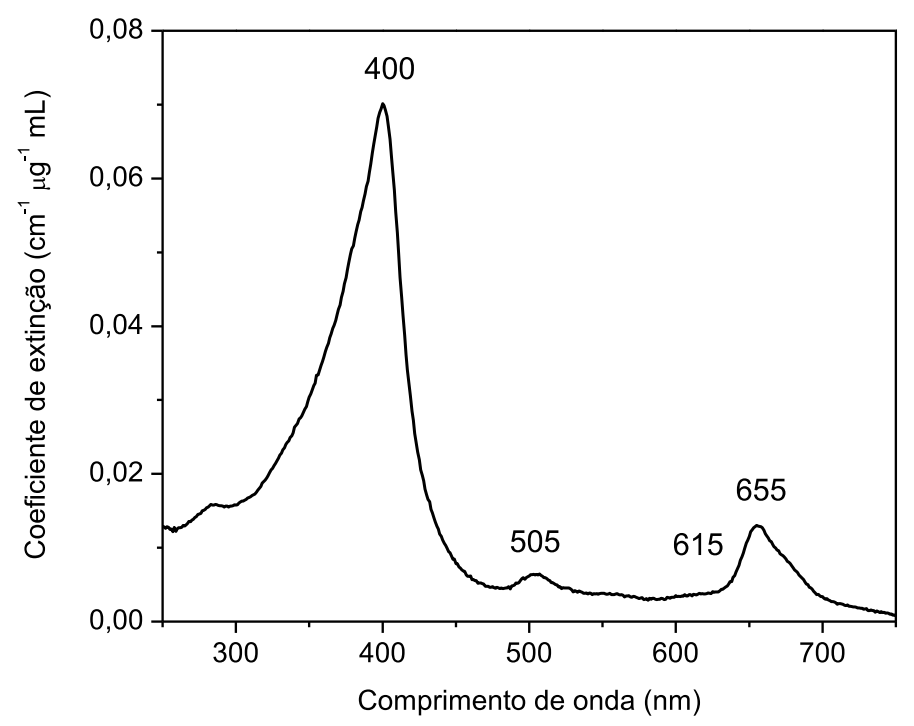

Figura 12 - Espectro de absorção ótica do PZ $15 \mu \mathrm{g} \mathrm{mL} \mathrm{L}^{-1}$, em PBS, $\mathrm{pH}=7,4$.

O Photodithazine apresenta máximo de absorção das bandas $Q$ em comprimento de onda maior (656 nm) que o PG (620 nm). Isto é uma vantagem do PZ em relação ao PG para aplicação em TFD, uma vez que a luz penetra mais profundamente na pele em comprimentos de onda maiores. Os coeficientes de extinção em $630 \mathrm{~nm}$, correspondente ao comprimento de onda do LED utilizado nesse trabalho, apresentaram uma grande diferença para os três FSs, sendo o coeficiente da HY superior ao do PG e do PZ. 


\subsection{Agregação dos fotossensibilizadores}

A agregação reduz a capacidade do composto de gerar oxigênio singlete. Isto porque os agregados provocam a diminuição do tempo de vida dos estados singlete e triplete do fotossensibilizador, resultando na diminuição do rendimento quântico de formação de oxigênio singlete, o que diminui a eficiência fotodinâmica do FS. Dessa forma é necessário que o princípio fotoativo apresente-se solubilizado e na forma monomérica ${ }^{136}$.

Para investigar a ocorrência de agregação, obteve-se os espectros de absorção ótica de soluções dos três FSs em PBS, pH 7,4 em diferentes concentrações (Figuras 13-15).
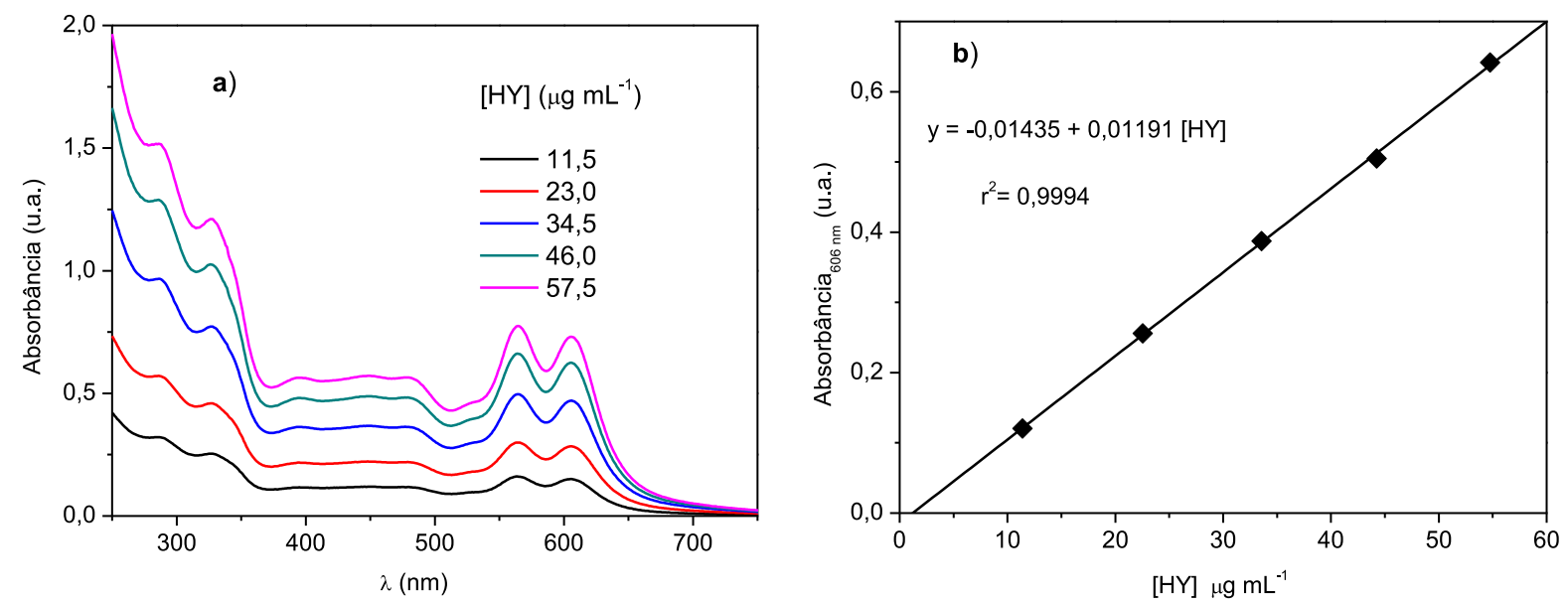

Figura 13 - a) Espectros de absorção ótica da HY em PBS, pH 7,4 em várias concentrações; b) Absorbância da Hipericina em PBS na banda em 606 nm em função da sua concentração. 

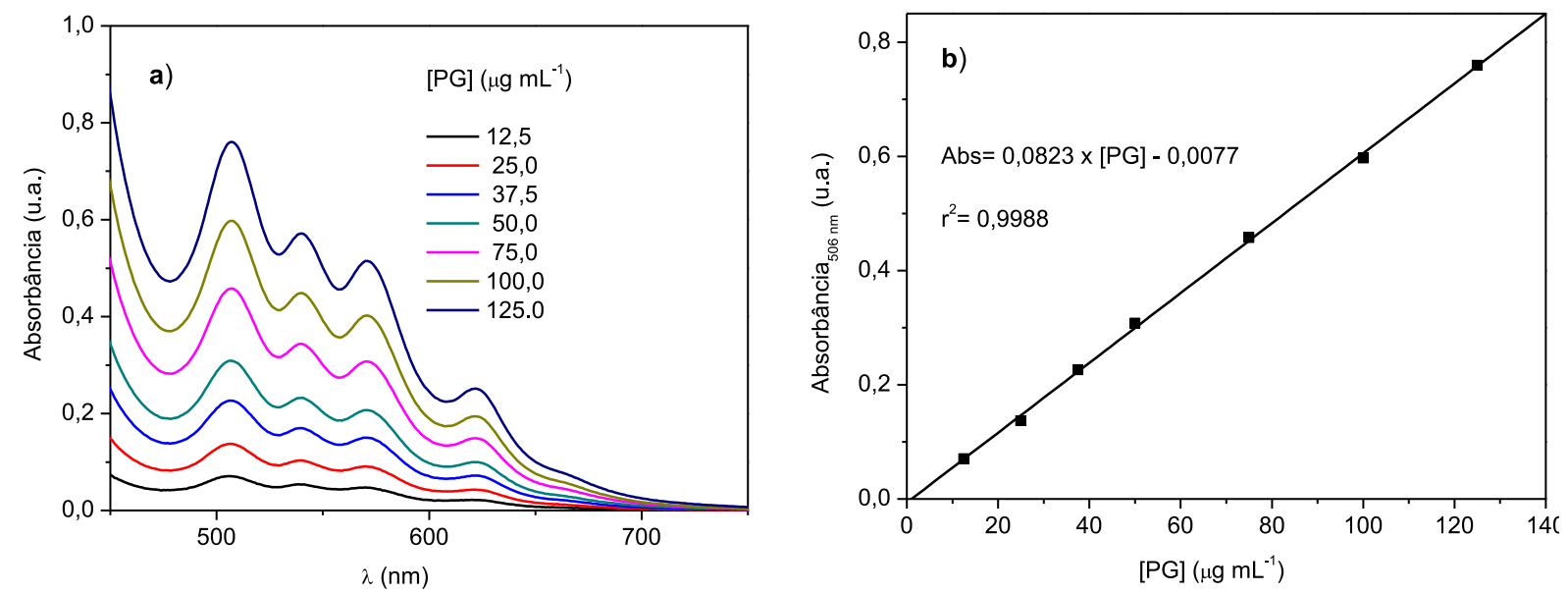

Figura 14 - a) Espectros de absorção ótica do PG em PBS, pH 7,4 em várias concentrações; b) Absorbância do Photogem em PBS na banda em 506 nm em função da sua concentração.
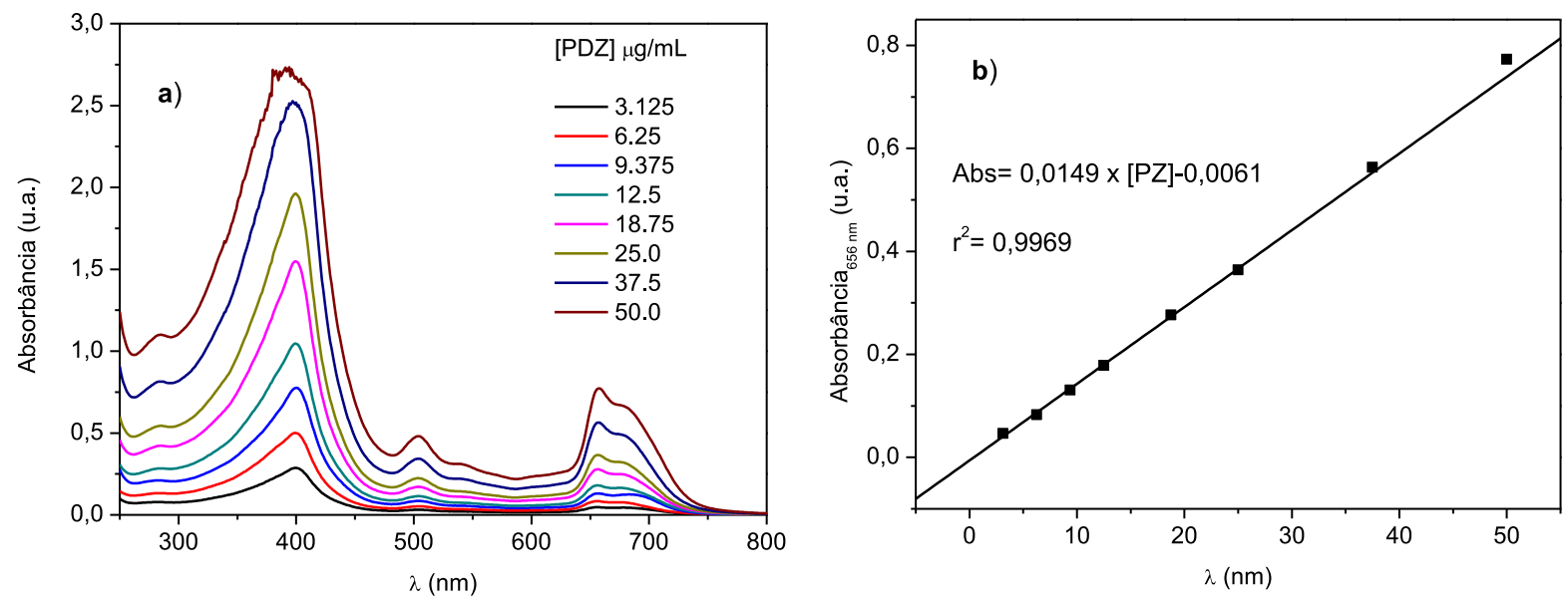

Figura 15 - a) Espectros de absorção ótica do PZ em PBS, pH 7,4 em várias concentrações; b) Absorbância do Photodithazine em PBS na banda em 656 nm em função da sua concentração.

Analisando-se os gráficos acima observa-se que as absorbâncias dos FSs apresentam-se lineares nas faixas de concentração estudadas, estando de acordo com a Lei de Lambert-Beer, o que sugere que até as concentrações estudadas não ocorre formação de agregados. Os ajustes foram feitos por regressão linear dos 
valores de absorbância em função da concentração obtendo-se valores de coeficientes de correlação linear.

\subsection{Estudo da estabilidade da Hipericina, Photodithazine e Photogem em função do tempo de armazenamento}

Foi realizado um controle da estabilidade em função do tempo de armazenamento dos fotossensibilizadores, após serem preparados em PBS ou DMSO, mantidos ao abrigo da luz e armazenados sob refrigeração à $4{ }^{\circ} \mathrm{C}$. Acompanhou-se a cada mês, ao longo de um período de 4 meses o espectro da Hipericina $15 \mathrm{\mu gmL}^{-1}$ em DMSO (Figura 16) e durante 6 meses, os espectros de absorção do Photogem e Photodithazine $15 \mu \mathrm{g} \mathrm{mL}^{-1}$ em PBS (Figuras 17 e 18).
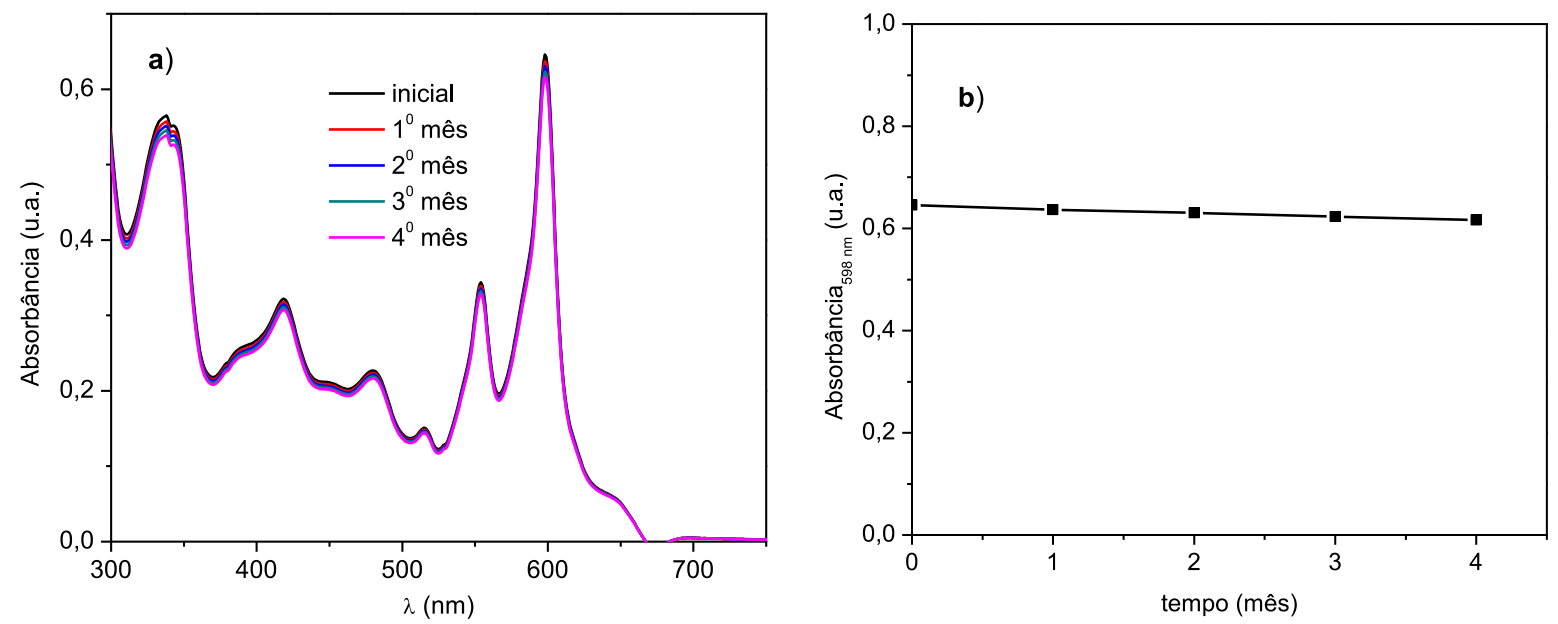

Figura 16 - a) Espectro de absorção ótica da HY $15 \mu \mathrm{gL}^{-1}$ em DMSO no período de 4 meses; b) Absorbância em $598 \mathrm{~nm}$ em função do tempo de armazenamento.

Embora não seja um método absoluto a medida da absorbância da solução após armazenamento permite comparar as amostras em diferentes tempos de 
estocagem. No caso da HY o preparo de soluções padrão para os experimentos foi realizado em média a cada 4 meses Pode-se observar que a solução de Hipericina é estável após um período de estocagem de 4 meses. A variação da absorbância em $598 \mathrm{~nm}$ foi de até $5 \%$ nesse período, que pode corresponder a uma pequena degradação da Hipericina. Karioti et al. ${ }^{51}$ relataram em seus estudos a manutenção da estabilidade da Hipericina no período de 140 dias, armazenada no escuro em $-20^{\circ} \mathrm{C}$.
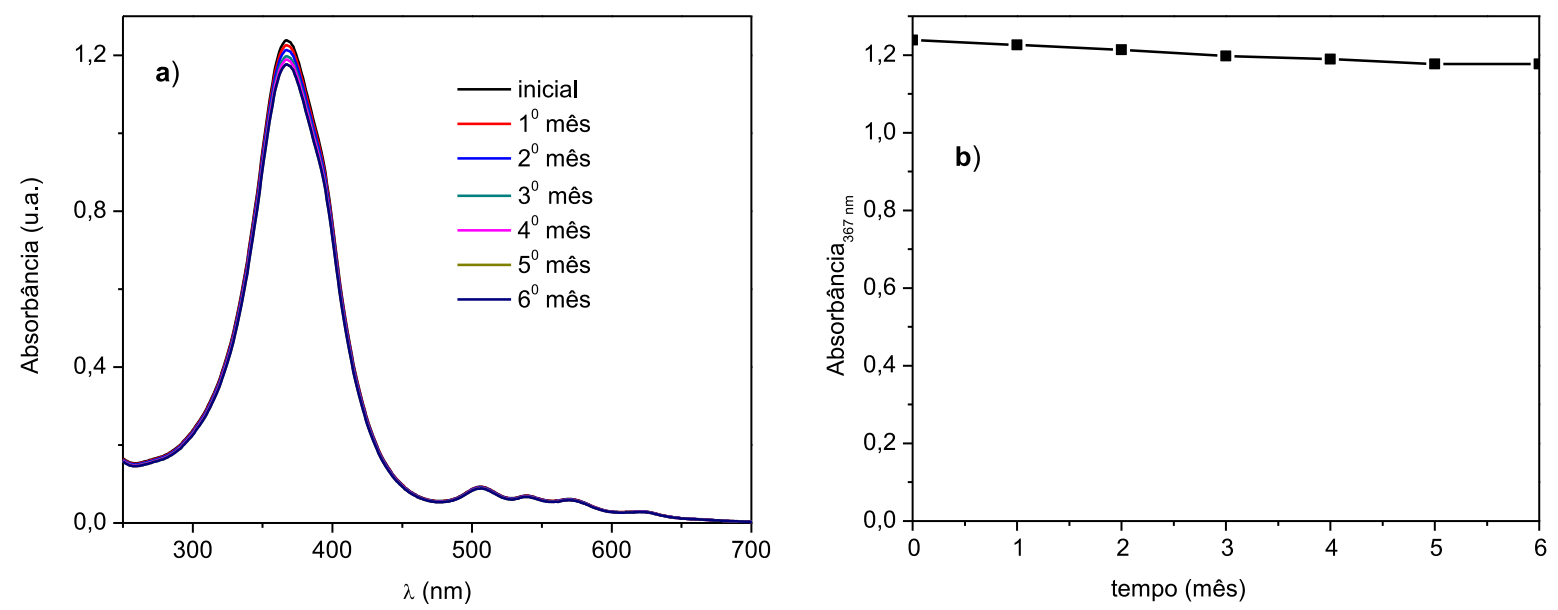

Figura 17 - a) Espectro de absorção ótica do PG $15 \mu \mathrm{g} \mathrm{mL}{ }^{-1}$ em PBS pH 7,4, no período de 6 meses; b) Absorbância em $367 \mathrm{~nm}$ em função do tempo de armazenamento.

Durante 6 meses foram obtidos espectros de absorção ótica de PG $15 \mu \mathrm{g} \mathrm{mL} \mathrm{L}^{-1}$ em PBS pH 7,4; como pode ser observado na Figura 17, a solução não apresentou mudanças em suas propriedades óticas tendo um decréscimo de até $6 \%$ no valor de absorbância na Banda de Soret. 

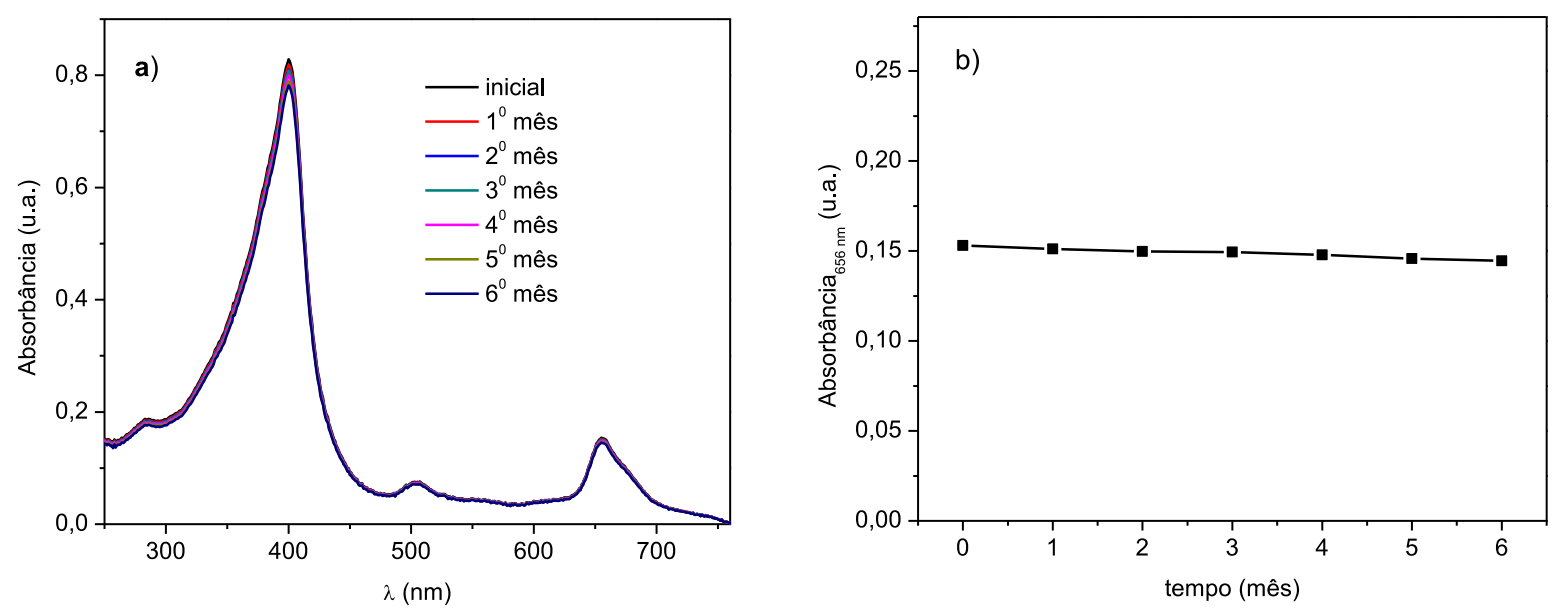

Figura 18 - a) Espectro de absorção ótica do PZ $15 \mu \mathrm{g} \mathrm{mL} \mathrm{L}^{-1}$ em PBS pH 7,4, no período de 6 meses; b) Absorbância em $596 \mathrm{~nm}$ em função do tempo de armazenamento.

O comportamento de estabilidade observado para a Hipericina e para o Photogem repetiu-se para o Photodithazine como observado na Figura 18. A diminuição na intensidade da absorção não ultrapassou $5 \%$, portanto a solução estoque de PZ manteve-se estável por 6 meses. Estes resultados são condizentes com a literatura onde é descrito que uma solução aquosa de Photodithazine permaneceu estável, apresentando um decréscimo na intensidade de absorção de $6 \%$, sendo estocada no escuro por um período maior do que 2 anos ${ }^{43}$.

Nesse trabalho todas as soluções estoque de FSs foram preparadas e utilizadas até no prazo de três meses.

\subsection{Estudo da estabilidade da Hipericina, Photodithazine e Photogem em função do tempo de irradiação}

Diversos fotossensibilizadores utilizados em TFD sofrem degradação pela luz ${ }^{137}$. O interesse na fotodegradação de corantes e pigmentos aumentou com os avanços tecnológicos e científicos, principalmente com a utilização do laser em 
fotomedicina ${ }^{31}$. Em TFD, os sensibilizadores estão presentes em altas concentrações nas células tumorais e ao redor das células normais. Desta forma, a fotodegradação dos fotossensibilizadores em taxas apropriadas durante a iluminação em TFD, pode vir a diminuir a concentração destes fotossensibilizadores nos tecidos normais, levando a uma diminuição da fototoxicidade, enquanto quantidade suficiente de fotossensibilizador pode persistir nas células tumorais para posterior fotodestruição, resultando em menor dano para o tecido normal. Deste modo verifica-se que a fotodegradação do fotossensibilizador é um elo fundamental da distribuição da dose fotodinâmica nos fluidos biológicos, estando relacionada com a cinética de eliminação do fotossensibilizador do organismo ${ }^{138}$.

A análise espectroscópica por absorção ótica foi realizada para uma solução de HY $50 \mu \mathrm{g} \mathrm{mL}^{-1}$ em PBS irradiada com LED vermelho I= $18 \mathrm{~mW} \mathrm{~cm}^{-2}$ durante 122 min (Figuras 19 e 20).

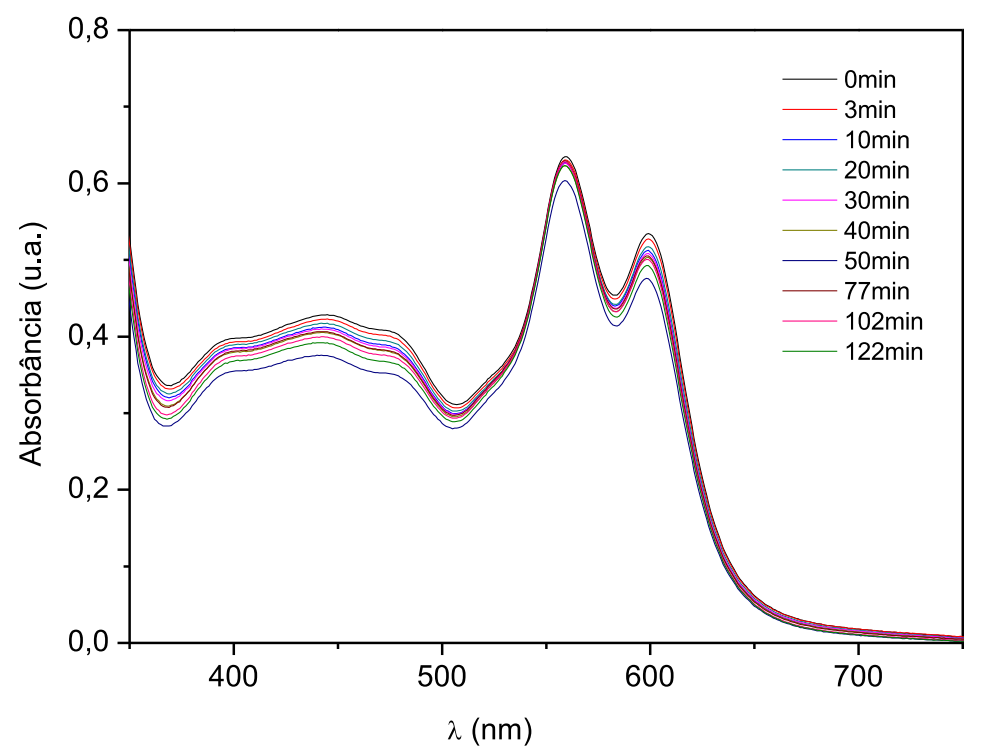

Figura 19 - Espectros de absorção ótica da HY $50 \mu \mathrm{gL}^{-1}$ em PBS irradiada com LED vermelho por até $122 \mathrm{~min}$. 

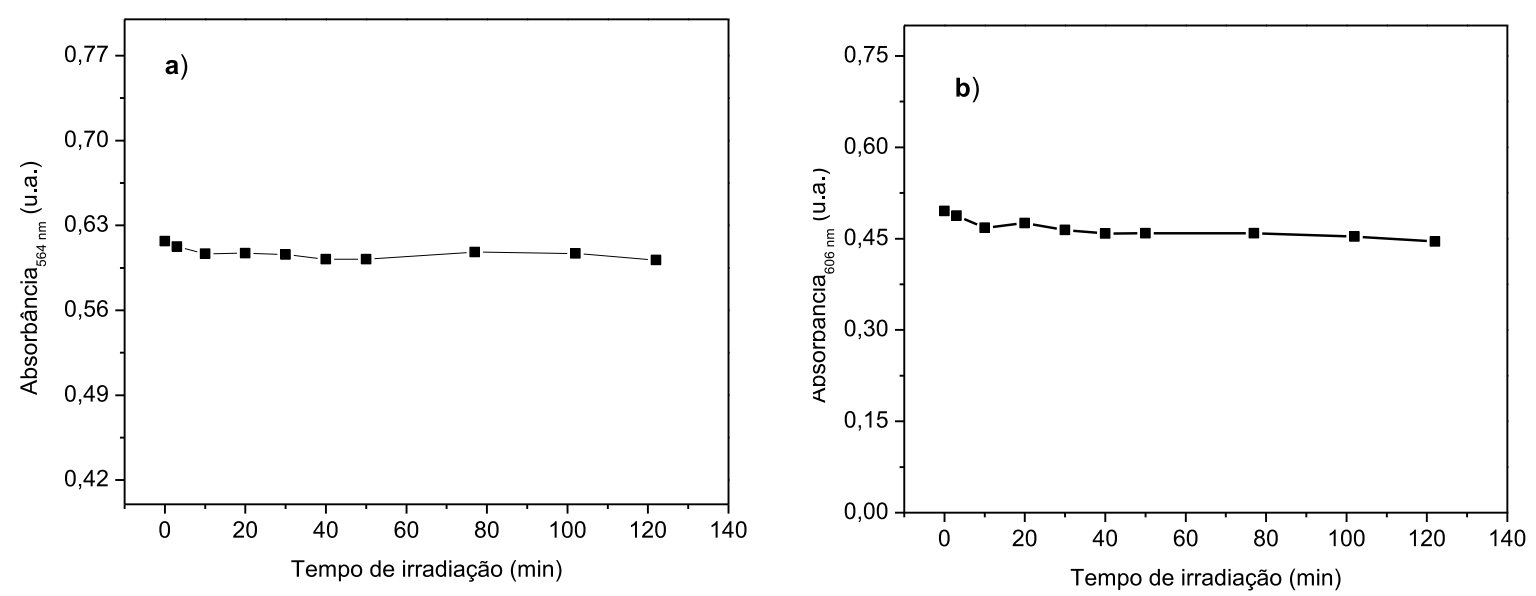

Figura 20 - Valores de absorbância da HY $50 \mu \mathrm{g} \mathrm{mL}^{-1}$ em PBS irradiada com LED vermelho por 122 min. a) Máximo de absorção em 564 nm; b) Máximo de absorção em 606 nm.

A Figura 20 apresenta a variação da absorbância das bandas em 564 e $606 \mathrm{~nm}$ da HY em função do tempo de irradiação com LED em $630 \mathrm{~nm}$, o que corrobora com estudos descritos na literatura que relatam a alta estabilidade da $\mathrm{HY}$ em solução após irradiação, sendo que a fotodegradação foi observada em extratos de pseudohipericina ${ }^{51}$.

Além do tempo de irradiação, a dose de luz deve ser controlada uma vez que o fotossensibilizador em altas doses pode vir a ser degradado parcialmente ou totalmente e causando deste modo uma menor citotoxicidade.

A fotoestabilidade do $P Z$ também foi estudada e os resultados estão mostrados na Figura 21. 


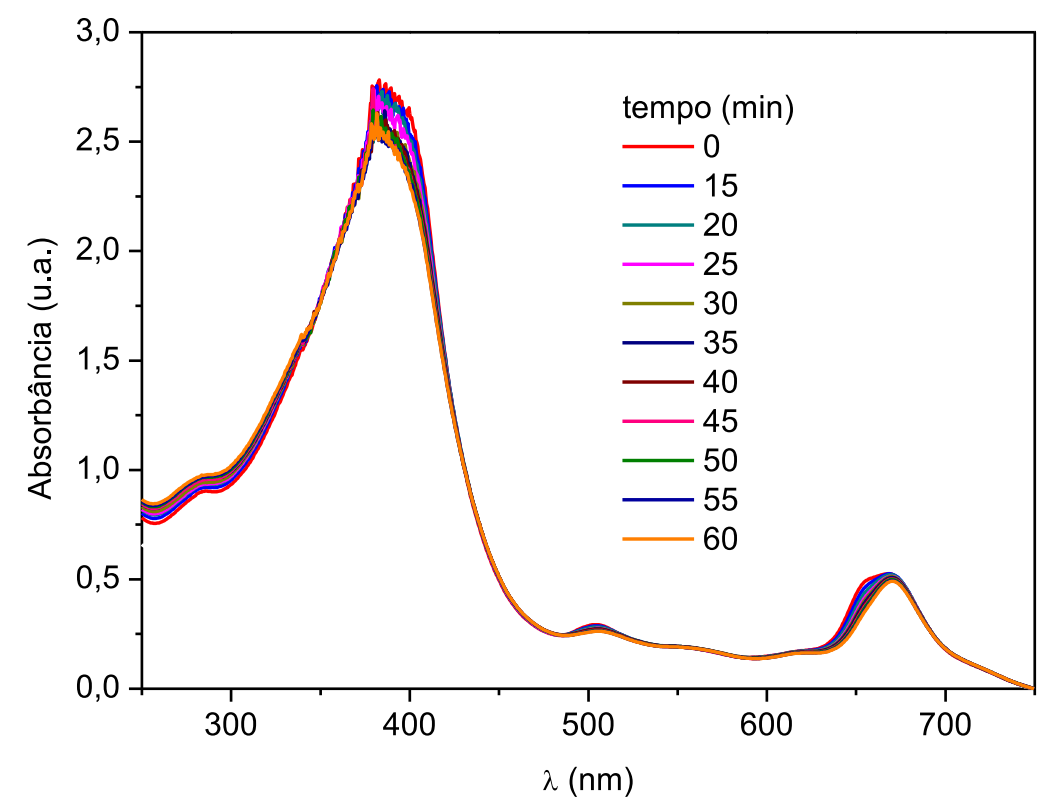

Figura 21 - Espectros de absorção ótica do PZ $50 \mu \mathrm{g} \mathrm{mL}^{-1}$ em PBS $(\mathrm{pH} 7,4)$ irradiado com LED vermelho $\mathrm{I}=18 \mathrm{~mW} \mathrm{~cm}{ }^{-2}$ por até $60 \mathrm{~min}$.

A partir destes espectros construi-se um gráfico com os valores de absorbância em 656 nm em função do tempo de irradiação (Figura 22).

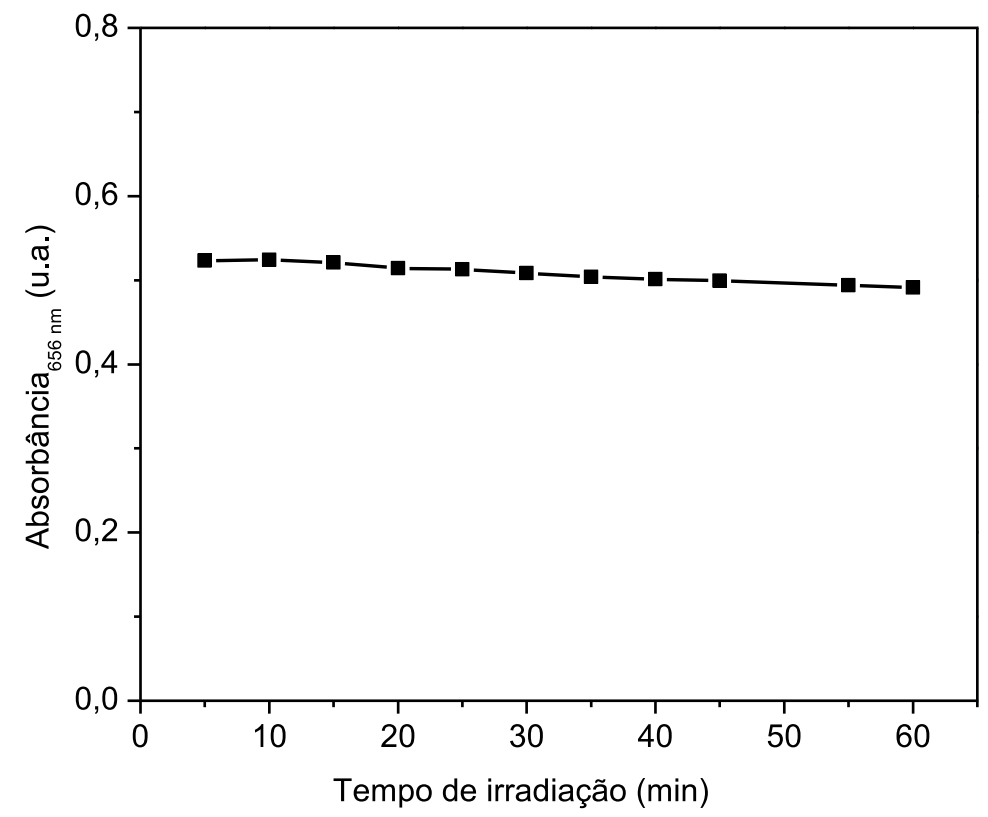

Figura 22 - Valores de absorbância do PZ $50 \mu \mathrm{gL}^{-1}$ em PBS $(\mathrm{pH} 7,4)$ irradiado com LED vermelho I $=18 \mathrm{~mW} \mathrm{~cm}^{-2}$ por $60 \mathrm{~min}$ em $656 \mathrm{~nm}$. 
Observou-se no espectro de absorção o decréscimo da absorção do PZ com o aumento da dose de irradiação, observa-se também o surgimento de uma nova banda em $668 \mathrm{~nm}$ atribuída à formação de fotoprodutos do Photodithazine, sugerindo transformações químicas levando à formação de fotoprodutos. Para a dose de irradiação máxima utilizada nesse trabalho $16,2 \mathrm{~J} \mathrm{~cm}^{-2}$, observou-se um decréscimo de $9 \%$ na banda em $656 \mathrm{~nm}$, resultado que está de acordo com estudos anteriores realizados no grupo de pesquisa ${ }^{139}$. Naquele trabalho Corrêa ${ }^{139}$ realizou uma série de estudos de fotodegradação do $\mathrm{PZ}$ em diferentes fontes de iluminação, entre elas laser de argônio em 488 nm e 514 nm e com LED em 630 nm e observou a formação de fotoprodutos em todas as fotodegradações. Esses fotoprodutos foram testados em linhagens celulares e apresentaram efeito fototóxico mais eficiente do que o $P Z$ não irradiado, além disso, observou também que a fotodegradação atingia uma saturação em torno de 20 min quando o $P Z$ era irradiado com LED em $630 \mathrm{~nm}$.

O acompanhamento da formação de fotoprodutos do PZ pela absorção em função do tempo de irradiação é dificultado devido ao fato destas substâncias se formarem e se fotodegradarem em processos simultâneos.

Estudos descritos na literatura da fotodegradação de vários FSs como derivados de hematoporfirina, clorinas e ftalocianinas, mostraram que a clorina $\mathrm{e}_{6}$ é a menos fotoestável da seqüência estudada. Segundo Rotomskis et al. ${ }^{140}$ e Bonnett et al. ${ }^{31}$., podem ocorrer mudanças espectrais devido à modificação fotoinduzida das porfirinas com ou sem a quebra do macrociclo. É descrito que a quebra do macrociclo implica no aparecimento de uma banda na região do UV após a irradiação, e ainda, que o não rompimento do macrociclo leva a uma diminuição da 
absorbância na banda de Soret e banda $Q$ associada ao surgimento de uma nova banda $Q$.

A análise espectroscópica por absorção ótica foi realizada para uma solução de Photogem $50 \mu \mathrm{g} \mathrm{mL}^{-1}$ em PBS $(\mathrm{pH} \mathrm{7,4)} \mathrm{irradiada} \mathrm{com} \mathrm{LED} 630 \mathrm{~nm}$ durante 60 min está apresentada na Figura 23.

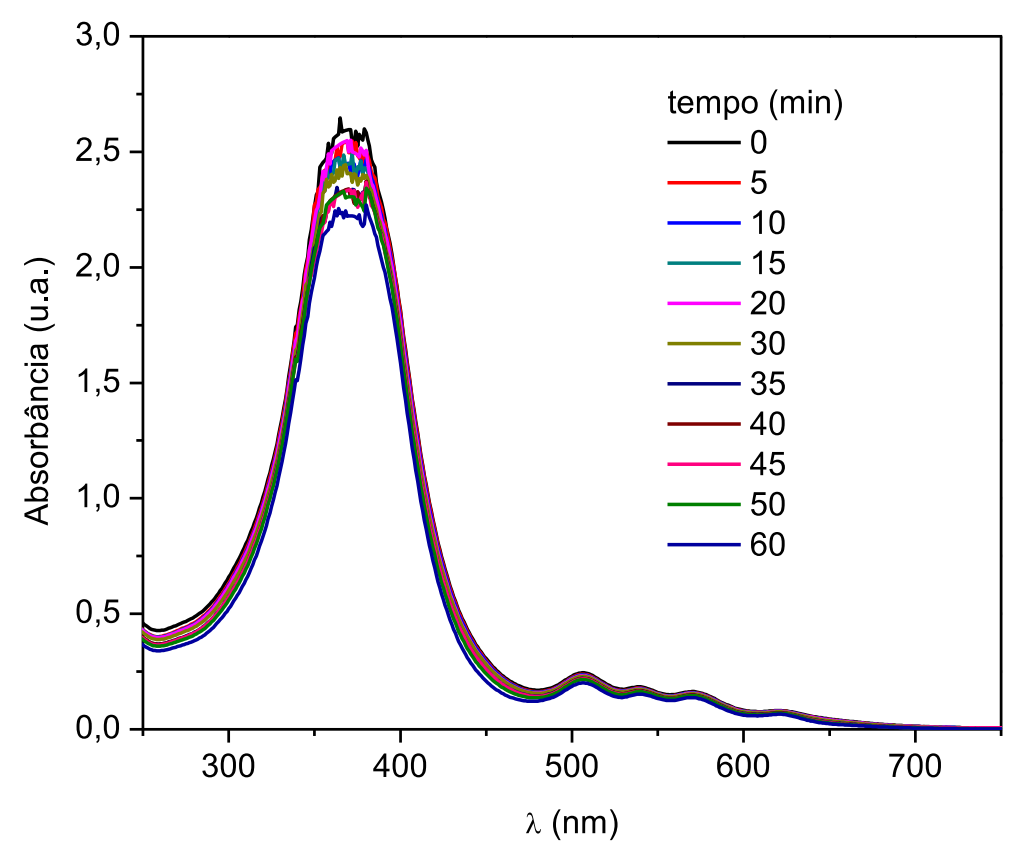

Figura 23 - Espectros de absorção ótica do PG $50 \mu \mathrm{g} \mathrm{mL}^{-1}$ em PBS (pH 7,4) irradiado com LED vermelho por até $60 \mathrm{~min}$.

Como pode ser observado na Figura 24 quando o Photogem foi irradiado em $632 \mathrm{~nm}$ observa-se uma diminuição da banda de Soret em $367 \mathrm{~nm}$ e diminuição das bandas Q $(506,539,570$ e $620 \mathrm{~nm})$, sugerindo transformações químicas levando à formação de fotoprodutos. Até o tempo de 15 min de irradiação a diminuição na intensidade das bandas foi de $2 \%$, como pode ser observado na Figura 24 que apresenta o decréscimo da intensidade da banda $506 \mathrm{~nm}$. Após $60 \mathrm{~min}$ de irradiação o decréscimo foi de $15 \%$. 


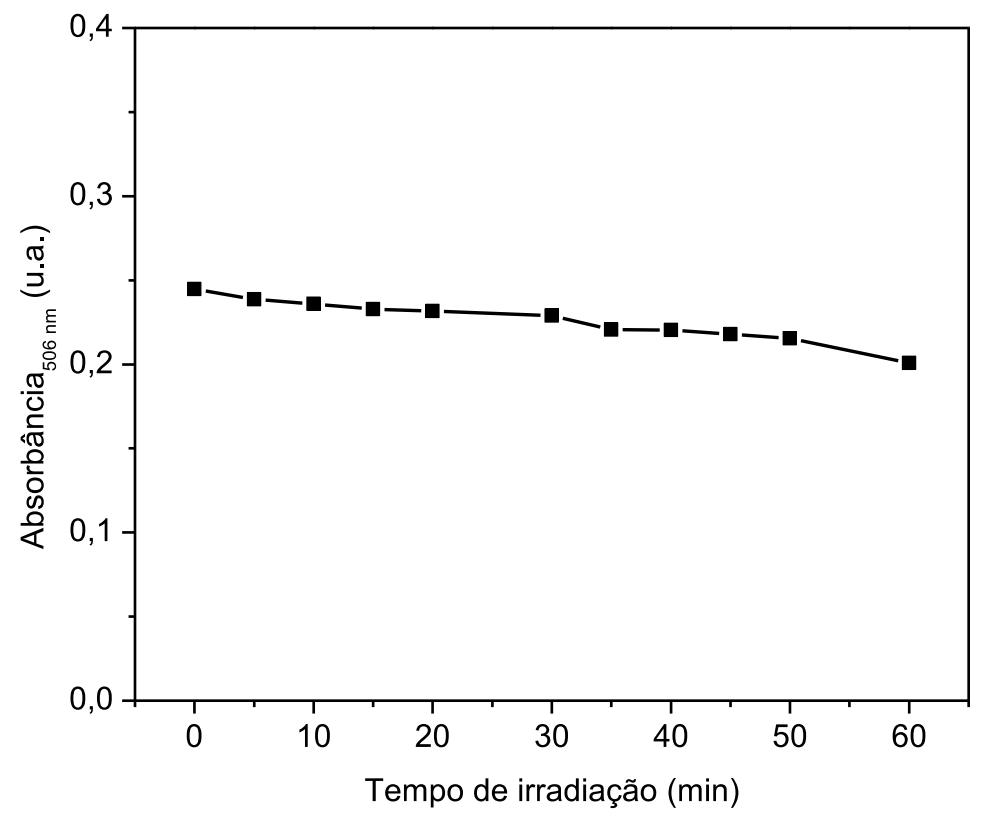

Figura 24 - Valores de absorbância em $656 \mathrm{~nm}$ do PG $50 \mu \mathrm{g} \mathrm{mL} \mathrm{L}^{-1}$ em PBS $(\mathrm{pH} 7,4)$ irradiado com LED vermelho $\mathrm{I}=18 \mathrm{~mW} \mathrm{~cm}^{-2}$ por $60 \mathrm{~min}$.

De acordo com a literatura, juntamente com a fotodegradação da droga durante a TFD, os FSs podem ser fotoquimicamente convertidos a novas espécies chamadas de fotoprodutos, processos que podem ser evidenciados pela diminuição da intensidade de absorção do FS durante a irradiação ${ }^{141}$. Menezes et al. ${ }^{142}$ realizou um extenso estudo sobre a fotodegradação do PG irradiado com laser de argônio em 488 nm, 514 nm e laser de corante bombeado por laser de argônio em $630 \mathrm{~nm}$ propondo, através de modelo matemático diversas análises de tempo de formação de fotoprodutos. Além disso, os autores estudaram a fototoxicidade desses fotoprodutos em células HEp-2 e Vero concluindo que esses fotoprodutos apresentavam menor eficiência do que o PG não irradiado. Nesse trabalho os ensaios com células HEp-2 e Vero não ultrapassaram 15 min de irradiação a fim de assegurar a menor interferência de possíveis fotoprodutos formados durante a irradiação. 


\subsection{Experimentos citotóxicos}

Foram realizados experimentos citotóxicos, como descrito no item 3.3, com as linhagens HEp-2 e Vero nos quais as células foram irradiadas com três doses de luz, ou seja, três tempos de irradiação com o LED vermelho e também com o LED amarelo, após 2 h de incubação com HY, PZ e PG a fim de se comparar qual deles apresentou a maior fototoxicidade. Foram também realizados experimentos citotóxicos com outras duas linhagens celulares a McCoy e B16-F10; foram testados os três FSs, HY, PZ e PG em apenas uma dose de luz, no LED vermelho. Ensaios citotóxicos na ausência de irradiação foram feitos a fim de se verificar a toxicidade intrínseca dos fotossensibilizadores nas células, ou seja, a citotoxicidade no escuro. Foram feitos controles da sobrevivência celular em diferentes tempos de incubação com DMSO, no escuro e com irradiação e também controles da sobrevivência celular após irradiação da luz visível na ausência de FS.

Os valores de $\mathrm{IC}_{50}$ apresentados nas tabelas que se seguem correspondem a um parâmetro inversamente proporcional à citotoxicidade, ou seja, quanto maior o valor de $\mathrm{IC}_{50}$ menor é a citotoxicidade do fotossensibilizador.

\subsubsection{Efeito do DMSO em cultura de células}

O DMSO foi o solvente utilizado para se preparar a solução estoque de Hipericina utilizada nos ensaios citotóxicos. A partir da solução estoque de HY obtiveram-se as diluições em meio de cultura, que em alguns experimentos continham até $1 \%(\mathrm{v} / \mathrm{v})$ de DMSO em diversos tempos de incubação. Para verificar 
se o DMSO era tóxico às células foram realizados experimentos nos quais se incubou $1 \%(v / v)$ de DMSO em meio de cultura nas linhagens HEp-2 e Vero, que foram incubadas por até $24 \mathrm{~h}$ e nas linhagens McCoy e B16-F10 que foram incubadas por $2 \mathrm{~h}$. Os índices de sobrevivência foram obtidos no claro e no escuro. Os resultados desses experimentos não evidenciaram alteração significativa na sobrevivência das células para todas as condições testadas, como indica a Figura 25. Esses resultados já eram esperados uma vez que o DMSO é um crioprotetor bastante conhecido e muito utilizado como solvente apolar em laboratórios e na indústria, apresentando baixa toxicidade ${ }^{143}$.
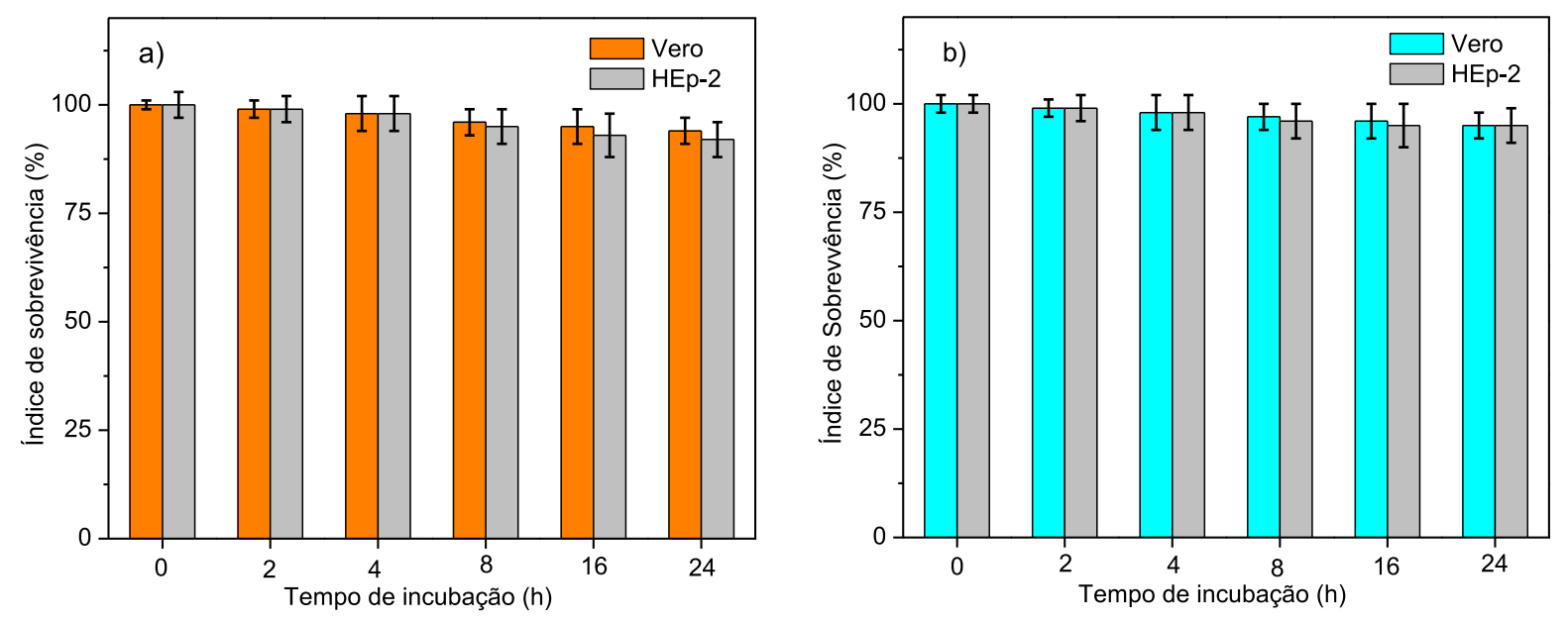

Figura 25 - Efeito do tempo de incubação com 1\% de DMSO sobre a proliferação da HEp-2 e da Vero em diferentes tempos de incubação no a) escuro, b) claro, 15 min de irradiação, LED (630 nm, $\mathrm{I}=18 \mathrm{~mW} \mathrm{~cm}^{-2}$ ). Os ensaios foram realizados três vezes em sextuplicata.

Além dos ensaios de citoxicidade os experimentos de determinação da acumulação do FSs, foram realizados com até $24 \mathrm{~h}$ de incubação, tendo então a necessidade de se obter o efeito do DMSO na proliferação celular para tempos de incubação superiores a 2 h. O decréscimo máximo encontrado no índice de sobrevivência foi de 5\% para a linhagem HEp-2, quando foi incubada com $1 \%$ de 
DMSO por $24 \mathrm{~h}$ seguida de irradiação com dose de $16,2 \mathrm{~J} \mathrm{~cm}^{-2}$. Estatisticamente os resultados não apresentaram diferenças significativas.

\subsubsection{Efeito da luz em cultura de células}

Foram realizados ensaios para verificar o efeito da luz de diferentes intensidades em dois comprimentos de onda em diferentes tempos de irradiação nas linhagens HEp-2 e Vero. As intensidades foram $18 \mathrm{~mW} \mathrm{~cm}^{-2}$ para o LED vermelho e $10 \mathrm{~mW} \mathrm{~cm}^{-2}$ para o LED amarelo. As doses utilizadas foram 4,3 a $32,4 \mathrm{~J} \mathrm{~cm}^{-2}$. Tais estudos foram utilizados como um controle do efeito da luz sobre a proliferação das células na ausência de droga e estão apresentados nas tabelas I e II. Estes experimentos foram utilizados como um segundo controle, pois em terapia fotodinâmica, somente a luz na ausência do FS não deve apresentar efeito tóxico às células. Deve-se ressaltar que na aplicação clínica de TFD dificilmente uma lesão é irradiada por tempo superior a $40 \mathrm{~min}$.

A intensidade de luz pode ser definida como a quantidade de energia transmitida ao alvo por unidade de tempo e é expressa em $\mathrm{mW} \mathrm{cm} \mathrm{cm}^{-2}$. A quantidade de energia transmitida durante todo o intervalo de tempo é definida como dose de luz, que por sua vez é expressa em $\mathrm{J} \mathrm{cm}^{-2}$. A relação entre intensidade de luz, dose de luz e tempo de irradiação é dada pela equação abaixo ${ }^{144}$ :

$$
I=\frac{D}{t}
$$

onde: $\mathrm{I}=$ intensidade de luz em $\mathrm{m} \mathrm{W} \mathrm{cm}^{-2}$ 
$D=$ dose de luz em $\mathrm{J} \mathrm{cm}^{-2}$

$t=$ tempo de irradiação em segundos

sendo que $1 \mathrm{~J}=1 \mathrm{~W} \times$ segundo

Tabela I - Resultados dos índices de sobrevivência da linhagem HEp-2 em função da dose de luz recebida dos LEDs vermelho e amarelo. Os experimentos foram feitos três vezes em sextuplicata.

\begin{tabular}{|c|c|c|}
\hline $\begin{array}{c}\text { Tempo de } \\
\text { irradiação (min) }\end{array}$ & Dose $\left(\mathrm{J} \mathrm{cm}^{-2}\right)$ & $\begin{array}{c}\text { IS (\%) } \pm \sigma \\
632 \mathrm{~nm} / 590 \mathrm{~nm}\end{array}$ \\
\hline $4 / 7$ & 4,3 & $95 \pm 2 / 93 \pm 3$ \\
\hline $8 / 14$ & 8,6 & $94 \pm 2 / 94 \pm 2$ \\
\hline $15 / 27$ & 16,2 & $95 \pm 4 / 93 \pm 5$ \\
\hline $30 / 54$ & 32,4 & $89 \pm 5 / 89 \pm 2$ \\
\hline
\end{tabular}

Tabela II - Resultados dos índices de sobrevivência da lionhagem Vero em função da dose de luz recebida dos LEDs vermelho e amarelo. Os experimentos foram feitos três vezes em sextuplicata.

\begin{tabular}{c|c|c}
\hline $\begin{array}{c}\text { Tempo de } \\
\text { irradiação (min) }\end{array}$ & Dose $\left(\mathbf{J ~ c m}^{-2}\right)$ & IS (\%) $\pm \boldsymbol{\sigma}$ \\
\hline $4 / 7$ & 4,3 & $\mathbf{6 3 2} \mathbf{~ n m ~ / ~ 5 9 0 ~} \mathbf{~ m}$ \\
$8 / 14$ & 8,6 & $98 \pm 3 / 99 \pm 4$ \\
$15 / 27$ & 16,2 & $95 \pm 3 / 94 \pm 3$ \\
$30 / 54$ & 32,4 & $94 \pm 6 / 94 \pm 4$ \\
\hline
\end{tabular}


A utilização de altas doses de luz pode causar um aquecimento local resultando em alterações nos níveis dos constituintes celulares sensíveis às variações de temperatura, tais como proteínas, DNA ou RNA, podendo levar a inibição do crescimento celular.

Cincotta et al. ${ }^{145}$ observaram a ocorrência de pequena morte celular em função da irradiação na ausência de droga com várias linhagens celulares e atribuíram este efeito à fotólise mediada por cromóforos celulares endógenos.

Pode-se observar nas tabelas I e II que não houve alterações significativas na sobrevivência das células para a maioria das condições experimentais, a maior morte celular chegou em $11 \%$ na maior dose, ou seja, de 32, 4 para o LED vermelho e amarelo. Desse modo, nos estudos citotóxicos na presença de luz, utilizou-se LED com tempo de irradiação máxima correspondendo a dose máxima de $16,2 \mathrm{~J} \mathrm{~cm}^{-2}$ para garantir que o efeito da luz não apresentasse efeito tóxico significativo às células.

\subsubsection{Efeito da dose de irradiação na fototoxicidade da HY, PZ e PG}

Nos estudos citotóxicos na presença de luz (claro) utilizou-se irradiação com LED em $630 \pm 10 \mathrm{~nm}$, intensidade de $18 \mathrm{~mW} \mathrm{~cm}^{-2}$ com os tempos de irradiação de 0, 4, 8 e $15 \mathrm{~min}$ e LED em $590 \pm 10 \mathrm{~nm}$ de intensidade de $10 \mathrm{~mW} \mathrm{~cm}^{-2}$ com tempos de irradiação de $0,7,14$ e 27 min. As células foram incubadas por 2 h com várias faixas de concentração: 0 a $10 \mu \mathrm{g} \mathrm{mL}{ }^{-1}$ para Hipericina, 0 a $20 \mu \mathrm{g} \mathrm{mL}^{-1}$ para Photodithazine e 0 a $150 \mu \mathrm{g} \mathrm{mL}^{-1}$ para o Photogem, em meio de cultura. A tabela III apresenta os resultados de $\mathrm{IC}_{50}$ obtidos para esses FSs para a linhagem HEp-2 sem 
irradiação (escuro) e em diferentes tempos de irradiação com o LED vermelho (630 nm) correspondendo a diferentes doses de luz.

Tabela III - Valores de $\mathrm{IC}_{50}$ da HY, PZ e PG para a linhagem HEp-2 após $2 \mathrm{~h}$ de incubação e irradiada com LED vermelho, $\mathrm{I}=18 \mathrm{~mW} \mathrm{~cm}^{-2}$ em diferentes doses de luz. Os experimentos foram realizados cinco vezes em sextuplicata para cada concentração.

\begin{tabular}{c|c|c|c|c}
\hline \multirow{2}{*}{$\begin{array}{c}\text { Tempo de } \\
\text { irradiação (min) }\end{array}$} & $\mathbf{D}\left(\mathrm{J} \mathrm{cm}^{-2}\right)$ & \multicolumn{3}{|c}{$\mathrm{IC}_{50} \pm \sigma\left(\mu \mathrm{g} \mathrm{mL} \mathbf{~}^{-1}\right)$} \\
\cline { 3 - 5 } & & $\mathrm{HY}$ & $\mathrm{PZ}$ & $\mathbf{P G}$ \\
\hline $\mathbf{0}$ & $\mathbf{0}$ & $3,0 \pm 0,4$ & $7 \pm 1$ & $64 \pm 1$ \\
$\mathbf{4}$ & $\mathbf{4 , 3}$ & $0,50 \pm 0,04$ & $4 \pm 1$ & $28 \pm 2$ \\
$\mathbf{8}$ & $\mathbf{8 , 6}$ & $0,20 \pm 0,02$ & $1,5 \pm 0,4$ & $13 \pm 1$ \\
$\mathbf{1 5}$ & $\mathbf{1 6 , 2}$ & $0,07 \pm 0,01$ & $1,0 \pm 0,2$ & $9 \pm 1$ \\
\hline
\end{tabular}

Os resultados mostram que há uma grande diferença nos valores de $\mathrm{IC}_{50}$ para esses FSs, sendo que a $\mathrm{HY}$ apresentou valores muito menores de $\mathrm{IC}_{50}$ para todas as doses testadas, por exemplo, para a dose de $16,2 \mathrm{~J} \mathrm{~cm}^{-2}$ um valor de quase 130 vezes menor que o PG e 14 vezes menor que o PZ. A HY também foi o FS de maior potencialização com a luz, na dose de $16,2 \mathrm{~J} \mathrm{~cm}^{-2}$ teve uma potencialização de 43 vezes, enquanto que as potencializações do PZ e PG foram de 7 vezes para cada após irradiação. Esses resultados sugerem que a HY, dentre os estudados, é o FS com maior citotoxicidade na presença de luz.

Fox et al. ${ }^{61}$ também observaram uma alta potencialização da HY após 20 min de irradiação com luz branca na inibição da proliferação de linfócitos. Esses autores observaram um decréscimo no valor do $\mathrm{IC}_{50}$ em torno de 32 vezes e que o 
aumento do tempo de irradiação para 30 min não levou a apresentar maior eficiência do que em 20 min de irradiação, concluindo que há um tempo de ativação necessário para a máxima eficiência da HY.

Luksiene et al. ${ }^{146}$ compararam a atividade antitumoral de vários FSs diferentes, sendo dois derivados de hematoporfirina, ácido 5-aminolevulínico e um derivado, Photofrin $\|^{\circledR}$ e Hipericina. Os experimentos foram feitos em carcinomas implantados em camundongos e foi acompanhado o decréscimo no tamanho do tumor. Após 15 dias do tratamento com $\mathrm{HY} 75 \%$ dos animais estavam praticamente curados, enquanto que o grupo tratado com os demais FSs não apresentaram diminuição no tamanho do carcinoma. Os autores concluíram que a HY apresentou maior eficiência no tratamento do carcinoma que os demais fotossensibilizadores.

A tabela IV apresenta os resultados de $\mathrm{IC}_{50}$ para Hipericina, Photodithazine e Photogem, após 2 h de incubação, em células normais Vero em diferentes doses de irradiação com LED vermelho, $\mathrm{I}=18 \mathrm{~mW} \mathrm{~cm}^{-2}$. 
Tabela IV - Valores de IC I0 $_{50}$ da HY, PZ e PG para a linhagem Vero após $2 \mathrm{~h}$ de incubação e irradiada com LED vermelho, $\mathrm{I}=18 \mathrm{~mW} \mathrm{~cm}^{-2}$ em diferentes doses de luz. Os experimentos foram realizados cinco vezes em sextuplicata para cada concentração.

\begin{tabular}{c|c|c|c|c}
\hline \multirow{2}{*}{$\begin{array}{c}\text { Tempo de } \\
\text { irradiação (min) }\end{array}$} & $\mathbf{D}\left(\mathbf{J ~ c m}^{-2}\right)$ & \multicolumn{3}{|c}{$\mathrm{IC}_{50} \pm \sigma\left(\mu \mathrm{g} \mathrm{mL} \mathbf{~}^{-1}\right)$} \\
\cline { 3 - 5 } & & $\mathrm{HY}$ & $\mathbf{P Z}$ & $\mathbf{P G}$ \\
\hline $\mathbf{0}$ & $\mathbf{0}$ & $7 \pm 1$ & $19 \pm 1$ & $68 \pm 7$ \\
$\mathbf{4}$ & $\mathbf{4 , 3}$ & $1,1 \pm 0,2$ & $6,9 \pm 0,4$ & $33 \pm 4$ \\
$\mathbf{8}$ & $\mathbf{8 , 6}$ & $0,7 \pm 0,1$ & $4,1 \pm 0,2$ & $18 \pm 1$ \\
\hline
\end{tabular}

Observou-se que a citotoxicidade da Hipericina, Photodithazine e Photogem aumenta tanto em células tumorais quanto em normais com o aumento do tempo de irradiação. É evidente que a citotoxicidade dos FSs, especialmente HY e PZ, é maior para as células tumorais HEp-2. Esses resultados sugerem que a acumulação celular para as células normais deve ser menor, levando a uma menor citotoxicidade.

Pode-se verificar que a mortalidade para as células tumorais em 4 min de irradiação é cerca de duas vezes maior que em células normais para a HY e PZ sendo que o PG apresentou a menor diferença de $I_{50}$ para todas as doses utilizadas nas duas linhagens. Com o aumento do tempo de irradiação de 4 para 8 min observou-se um aumento no $\mathrm{IC}_{50}$ em torno de 4 vezes para a $\mathrm{HY}$ e 3 vezes para o PZ e em 15 min o mesmo resultado foi observado para a HY enquanto para o PZ e PG houve um decréscimo do aumento. A HY foi o FS que apresentou $\mathrm{IC}_{50}$ 
menor valor para a linhagem Vero e também a maior potencialização em todas as doses testadas.

A Figura 26 ilustra a potencialização dos FSs em função do tempo de irradiação em células tumorais HEp-2 e normais Vero.
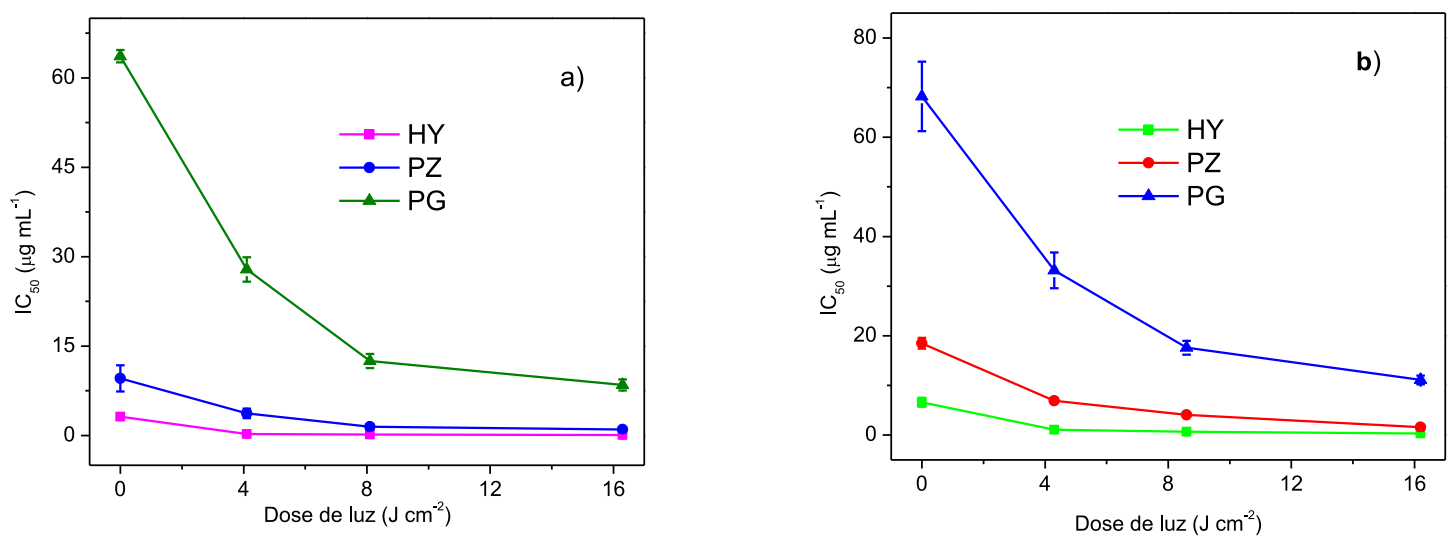

Figura 26 - Efeito da dose de luz em $632 \mathrm{~nm}$ no $\mathrm{IC}_{50}$ após duas horas de incubação com HY, PZ e $P G$, a) linhagem HEp-2 e b) linhagem Vero.

Os resultados apresentados na Figura 26 indicam que quanto maior o tempo de irradiação maior a fototoxicidade dos FSs, mas com uma tendência de estabilização para doses maiores que $10 \mathrm{~J} \mathrm{~cm}^{-2}$ aproximadamente. Outro dado interessante é o baixo valor de $\mathrm{IC}_{50}$ da $\mathrm{HY}$ no escuro, se comparada ao Photogem e ao Photodithazine. Essa citotoxicidade da HY no escuro pode ser devido ao fato bem conhecido da HY ser um inibidor da proteína quinase $\mathrm{c}$ e indutor do citrocomo $\mathrm{c}$ liberado pela mitocôndria. A proteína quinase c está envolvida em eventos de transdução de sinais respondendo a estímulos específicos hormonais, neuronais e de fatores de crescimento celular ${ }^{147}$.

Estudos realizados por Banfi et al. ${ }^{47}$ com células tumorais de colo de útero mostraram que Foscam ${ }^{\circledR}$ (clorina) é significativamente mais citotóxico no claro, IC $\mathrm{I}_{50}$ 
igual a $24,8 \mathrm{ng} \mathrm{mL}^{-1}$, do que o Photofrin ${ }^{\circledR}$ (derivado de hematoporfirina) com $\mathrm{IC}_{50}$ de $74 \mathrm{ng} \mathrm{mL} \mathrm{m}^{-1}$. Ambos os estudos relatados concordam com os apresentados neste trabalho.

Foram realizados ensaios citotóxicos com células normais McCoy e tumorais B16-10 com a Hipericina, Photodithazine e Photogem, 2 h de incubação, no escuro e também com $15 \mathrm{~min}$ de irradiação com LED vermelho, $\mathrm{I}=18 \mathrm{~mW} \mathrm{~cm}^{-2}$. Os resultados de $\mathrm{IC}_{50}$ estão apresentados nas tabelas $\mathrm{V}$ e $\mathrm{VI}$.

Tabela V - Valores de $\mathrm{IC}_{50}$ dos FSs HY, PZ e PG para a linhagem B16-F10 após $2 \mathrm{~h}$ de incubação e irradiada por $15 \mathrm{~min}$ com LED $\Lambda=630 \mathrm{~nm}, \mathrm{I}=18 \mathrm{~mW} \mathrm{~cm}{ }^{-2}$. Os experimentos foram realizados quatro vezes em sextuplicata para cada concentração.

\begin{tabular}{|c|c|c|c|c|}
\hline \multirow{2}{*}{$\begin{array}{c}\text { Tempo de } \\
\text { irradiação (min) }\end{array}$} & \multirow{2}{*}{$\mathrm{D}\left(\mathrm{J} \mathrm{c \textrm {cm } ^ { - 2 } )}\right.$} & \multicolumn{3}{|c|}{$\mathrm{IC}_{50} \pm \sigma\left(\mu \mathrm{g} \mathrm{mL} \mathrm{L}^{-1}\right)$} \\
\hline & & HY & $\mathbf{P Z}$ & PG \\
\hline 0 & 0 & $6,3 \pm 0,2$ & $14 \pm 3$ & $40 \pm 3$ \\
\hline 15 & 16,2 & $0,25 \pm 0,02$ & $3,0 \pm 0,2$ & $11,2 \pm 0,4$ \\
\hline
\end{tabular}


Tabela VI - Valores de $\mathrm{IC}_{50}$ dos FS HY, PZ e PG para a linhagem McCoy após $2 \mathrm{~h}$ de incubação e irradiada por $15 \mathrm{~min}$ com LED $\Lambda=630 \mathrm{~nm}, \mathrm{I}=18 \mathrm{~mW} \mathrm{~cm} \mathrm{c}^{-2}$. Os experimentos foram feitos cinco vezes em sextuplicata para cada concentração.

\begin{tabular}{c|c|c|c|c}
\hline \multirow{2}{*}{$\begin{array}{c}\text { Tempo de } \\
\text { irradiação (min) }\end{array}$} & D ( $\left.\mathrm{J} \mathrm{cm}^{-2}\right)$ & \multicolumn{3}{|c}{ IC $_{50} \pm \sigma\left(\mu \mathrm{g} \mathrm{mL}^{-1}\right)$} \\
\cline { 3 - 5 } & & HY & PZ & PG \\
\hline $\mathbf{0}$ & $\mathbf{0}$ & $2,4 \pm 0,1$ & $6 \pm 1$ & $28 \pm 2$ \\
\hline 15 & $\mathbf{1 6 , 2}$ & $0,04 \pm 0,01$ & $0,8 \pm 0,2$ & $3 \pm 1$ \\
\hline
\end{tabular}

Pode-se observar que a Hipericina foi o fotossensibilizador que apresentou o menor valor de $\mathrm{IC}_{50}$ para as duas linhagens testadas na dose de $16,2 \mathrm{~J} \mathrm{~cm}^{-2}$. Observou-se que a linhagem McCoy, apesar de ser uma célula epitelial normal, apresentou maior suscetibilidade que as duas linhagens de células tumorais HEp-2 e B16-F10 e a normal Vero. No estudo realizado por Vandenbogaerde et al. ${ }^{148}$ foram determinados os valores de $\mathrm{IC}_{50}$ de uma Hipericina comercial, no escuro e após irradiação, em várias linhagens celulares tumorais, como HeLa um carcinoma humano da região cervical, DU 145 carcinoma de próstata, MCF7 adenocarcinoma de mama, entre outras tumorais e 3T3 uma linhagem não tumoral de fibroblasto de camundongo. Foi observado um valor de $\mathrm{IC}_{50}$ para a $\mathrm{HY}$ menor para as células normais do que para algumas linhagens tumorais. Uma hipótese considerada pelos autores seria a concentração em nível normal de glutadiona em células tumorais provocando um efeito contrário ao esperado, ou seja, um aumento da proliferação de células malignas. A glutadiona é um antioxidante hidrossolúvel, está presente em todas as células e tem um papel crucial na metabolização de xenobióticos e na desativação de radicais. A mitocôndria e o núcleo celular têm a sua própria reserva 
de glutadiona justamente para se proteger da ação das espécies reativas de oxigênio. Então dessa forma as espécies reativas de oxigênio quando são formadas após irradiação poderiam ser neutralizadas, levando a valores distintos de $\mathrm{IC}_{50}$.

Foram realizados experimentos de citotoxicidade com as células HEp-2 e Vero sendo incubadas com Hipericina, Photogem e Photodithazine por duas horas e irradiadas com LED em $590 \pm 11 \mathrm{~nm}$ (amarelo) de intensidade de $10 \mathrm{~mW} \mathrm{~cm}{ }^{-2}$ em diferentes tempos, mas que correspondesse a três doses utilizadas nos ensaios com o LED vermelho, a fim de se comparar o efeito do comprimento de onda da luz. As células, HEp-2 e Vero foram incubadas por $2 \mathrm{~h}$ com várias faixas de concentração: 0 a $2 \mu \mathrm{g} \mathrm{mL}^{-1}$ para Hipericina, 0 a $15 \mu \mathrm{g} \mathrm{mL}^{-1}$ para Photodithazine e 0 a $30 \mu \mathrm{g} \mathrm{mL}^{-1}$ para o Photogem, em meio de cultura. A tabela VII apresenta os resultados de $\mathrm{IC}_{50}$ obtidos para esses $\mathrm{FSs}$ para a linhagem HEp-2 na ausência de luz (escuro) e em diferentes tempos de irradiação. 
Tabela VII - Valores de $\mathrm{IC}_{50}$ dos FS HY, PZ e PG para a linhagem HEp-2 após $2 \mathrm{~h}$ de incubação e irradiados em diferentes doses de luz com LED $\Lambda=590 \mathrm{~nm}, \mathrm{l}=10 \mathrm{~mW} \mathrm{~cm}{ }^{-2}$. Os experimentos foram feitos três vezes em sextuplicata para cada concentração.

\begin{tabular}{c|c|c|c|c}
\hline \multirow{2}{*}{$\begin{array}{c}\text { Tempo de } \\
\text { irradiação (min) }\end{array}$} & $\mathbf{D}\left(\mathbf{J ~ c m}^{-2}\right)$ & \multicolumn{3}{|c}{$\mathrm{IC}_{50} \pm \sigma\left(\mu \mathrm{mL}^{-1}\right)$} \\
\cline { 3 - 5 } & & $\mathrm{HY}$ & $\mathbf{P Z}$ & $\mathbf{P G}$ \\
\hline $\mathbf{0}$ & $\mathbf{0}$ & $3,0 \pm 0,4$ & $7 \pm 1$ & $64 \pm 1$ \\
$\mathbf{7}$ & $\mathbf{4 , 3}$ & $0,070 \pm 0,007$ & $4,6 \pm 0,2$ & $13 \pm 2$ \\
$\mathbf{1 4}$ & $\mathbf{8 , 6}$ & $0,036 \pm 0,001$ & $2,8 \pm 0,3$ & $6,5 \pm 0,4$ \\
$\mathbf{2 7}$ & $\mathbf{1 6 , 2}$ & $0,020 \pm 0,002$ & $1,5 \pm 0,1$ & $2,5 \pm 0,3$ \\
\hline
\end{tabular}

Comparando os resultados obtidos após incubação e irradiação com a luz amarela e vermelha nota-se um decréscimo nos valores de $\mathrm{IC}_{50}$ de até 7 vezes para a Hipericina e de até 3,6 vezes para o Photogem com luz amarela. Para o Photodithazine o $\mathrm{IC}_{50}$ obtido teve um aumento, ou seja foi menos efetivo. Esses resultados já eram esperados uma vez que o coeficiente de extinção máximo da HY encontra-se mais próximo de $590 \mathrm{~nm}$, portanto nesse comprimento de onda a $\mathrm{HY}$ absorve mais energia e na presença de $\mathrm{O}_{2}$ produz mais substâncias citotóxicas às células. O Photogem também apresenta um coeficiente de extinção maior em comprimentos de ondas mais próximo de $590 \mathrm{~nm}$, portanto também absorve mais energia. Já o Photodithazine tem coeficiente de extinção menor em 590 nm, necessitando de mais fotossensibilizador para inibir a proliferação celular. 
A tabela VIII apresenta os resultados de $I_{50}$ obtidos para os FSs após incubação por $2 \mathrm{~h}$ nas células Vero e irradiação em diferentes tempos com o LED $\Lambda=590 \mathrm{~nm}$ (amarelo), $\mathrm{I}=10 \mathrm{~mW} \mathrm{~cm}^{-2}$.

Tabela VIII - Valores de IC $_{50}$ para a linhagem Vero após $2 \mathrm{~h}$ de incubação e HY, PZ e PG irradiados em diferentes doses de luz com LED $\Lambda=590 \mathrm{~nm}$. Os experimentos foram feitos três vezes em sextuplicata para cada concentração.

\begin{tabular}{c|c|c|c|c}
\hline \multirow{2}{*}{$\begin{array}{c}\text { Tempo de } \\
\text { irradiação (min) }\end{array}$} & $\mathbf{D}\left(\mathrm{J} \mathrm{cm}^{-2}\right)$ & \multicolumn{3}{|c}{ IC $_{50} \pm \sigma\left(\mu \mathrm{g} \mathrm{mL} \mathbf{~}^{-1}\right)$} \\
\cline { 3 - 5 } & & $\mathrm{HY}$ & $\mathrm{PZ}$ & PG \\
\hline $\mathbf{0}$ & $\mathbf{0}$ & $7 \pm 1$ & $19 \pm 1$ & $68 \pm 7$ \\
$\mathbf{7}$ & $\mathbf{4 , 3}$ & $0,082 \pm 0,004$ & $8,6 \pm 0,3$ & $23 \pm 2$ \\
$\mathbf{1 4}$ & $\mathbf{8 , 7}$ & $0,041 \pm 0,001$ & $6,0 \pm 0,2$ & $8,8 \pm 0,4$ \\
$\mathbf{2 7}$ & $\mathbf{1 6 , 2}$ & $0,030 \pm 0,001$ & $2,4 \pm 0,1$ & $5,7 \pm 0,5$ \\
\hline
\end{tabular}

Os resultados são semelhantes aos obtidos na linhagem HEp-2 quando foi irradiada com LED amarelo; os valores de $\mathrm{IC}_{50}$ para a $\mathrm{HY}$ e Photogem diminuíram e o valor do $\mathrm{IC}_{50}$ para o Photodithazine aumentou em torno de duas vezes.

A Figura 27 mostra a relação de $I_{50}$ da Hipericina, Photogem e Photodithazine após 2 horas de incubação e 8 min de irradiação com LED vermelho, $D=8,6 \mathrm{~J} \mathrm{~cm}^{-2}$ para as linhagens HEp-2 e Vero. 


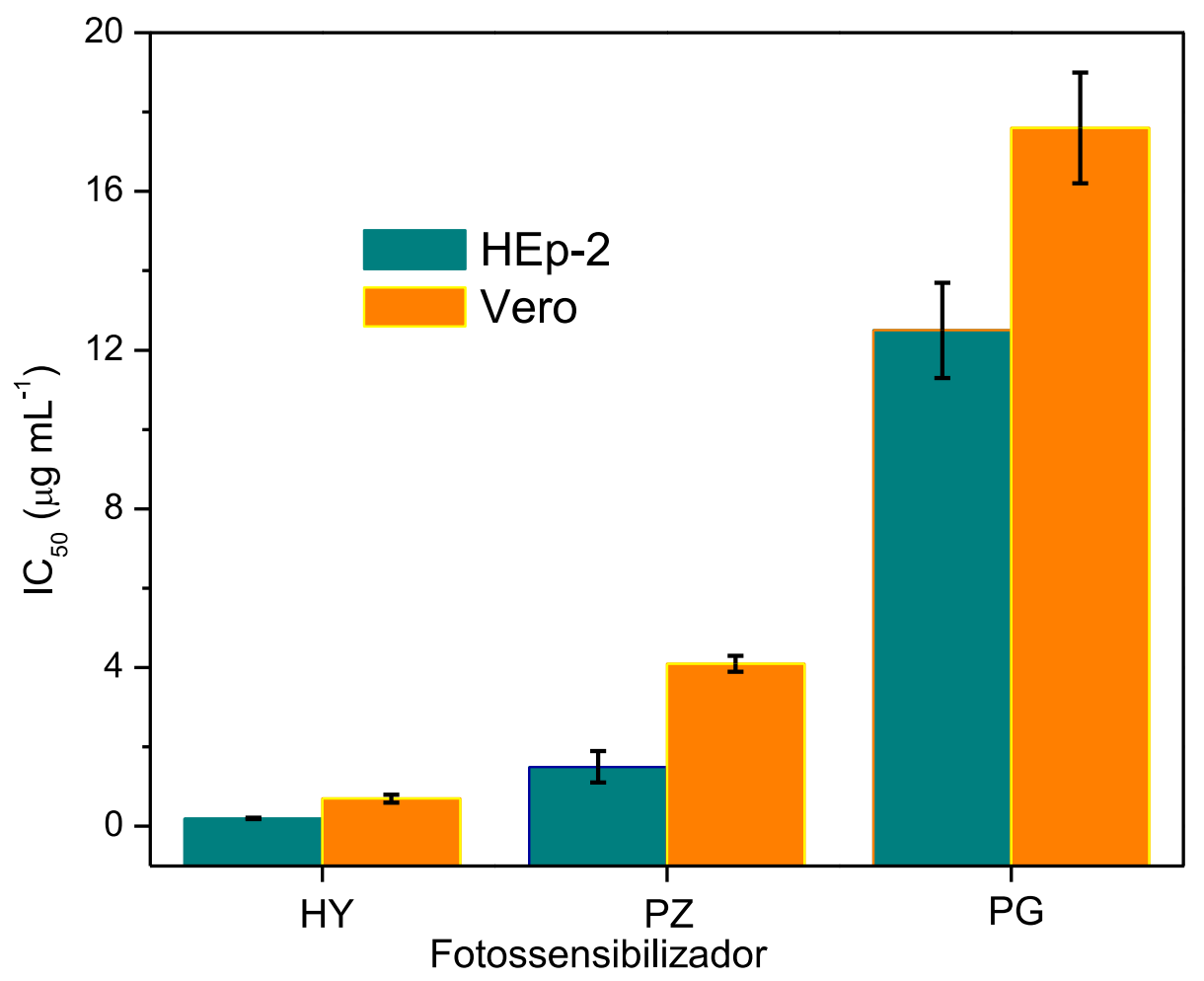

Figura 27 - Valores de $\mathrm{IC}_{50}$ para a HY, PG e PZ, nas células HEp-2 e Vero, obtidos após 2 horas de incubação e 8 min de irradiação no LED vermelho, $D=8,6 \mathrm{~J} \mathrm{~cm}^{-2}$.

Através da Figura 27 fica evidente a maior citoxicidade da HY seguida pelo PZ e PG, para as duas linhagens testadas. Os resultados corroboram com a literatura que coloca a HY como um dos mais potentes fotossensibilizadores encontrados na natureza ${ }^{51}$.

A Figura 28 apresenta uma comparação dos $\mathrm{IC}_{50}$ para as duas linhagens, HEp-2 e Vero, dos FSs HY, PZ e PG após 2 h de incubação e 27 min de irradiação no LED amarelo resultando numa $D=16,2 \mathrm{~J} \mathrm{~cm}^{-2}$. 


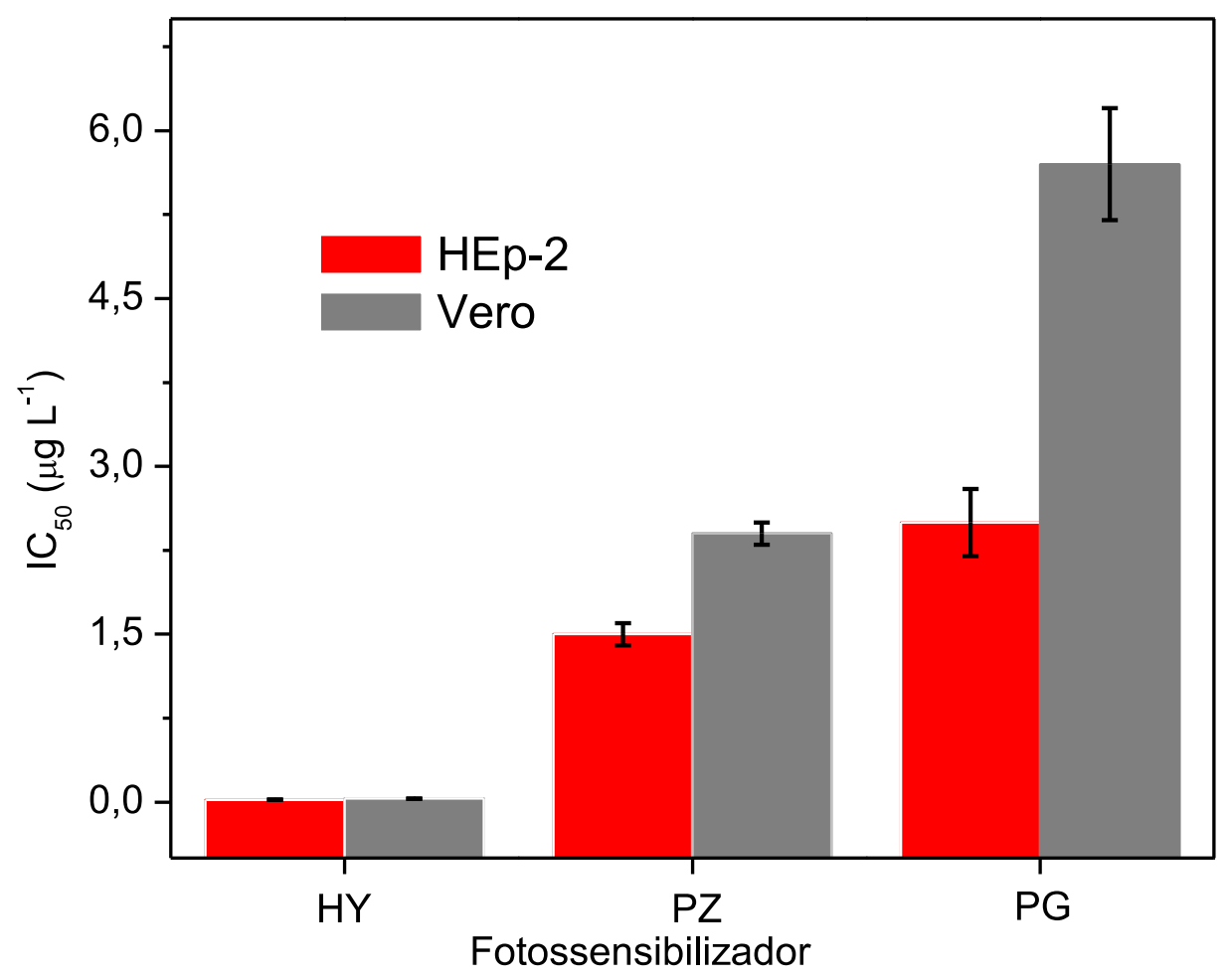

Figura 28 - Valores de $\mathrm{IC}_{50}$ para a HY, PG e PZ, nas células HEp-2 e Vero, obtidos após 2 horas de incubação e 27 min de irradiação no LED amarelo, $D=16,2 \mathrm{~J} \mathrm{~cm}^{-2}$.

Os resultados apresentados na Figura 28 evidenciam a diferença entre a atividade fototóxica da HY frente ao PZ e PG após irradiação com luz amarela. Em todos os experimentos de citotoxicidade realizados com as quatro linhagens celulares, duas não tumorais Vero e McCoy e duas tumorais HEp-2 e B16-F10, a Hipericina mostrou maior citotoxicidade após irradiação com ambos os LEDs, vermelho e amarelo, seguida pelo Photodithazine e Photogem. Blank et al ${ }^{149}$ analisaram os efeitos na proliferação celular de dois tipos de carcinoma in vitro após $2 \mathrm{~h}$ de incubação com HY e irradiação com diversas doses de luz de comprimento de onda em $550 \mathrm{~nm}$ (verde) e $590 \mathrm{~nm}$ (amarelo) e encontraram um decréscimo duas vezes maior na proliferação celular após irradiação com luz amarela, uma relação muito semelhante a encontrada nesse trabalho. Foi observada também uma 
dependência dos valores de $\mathrm{IC}_{50}$ com o aumento da dose de irradiação, ou seja, os FSs apresentaram decréscimo nos valores de $\mathrm{IC}_{50}$ com o aumento da dose de irradiação, sendo que a HY apresentou a maior potencialização em todos os casos testados, novamente seguida pelo Photodithazine e Photogem.

\subsection{Interação dos FSs com albumina de soro bovino}

A fotoxidação da BSA foi uma das metodologias utilizadas para avaliar a eficiência fotodinâmica dos três FSs estudados. A Figura 29 apresenta a variação nos espectros de emissão durante a fotoxidação da BSA obtida durante a incubação por 60 min na presença dos FSs, acompanhada através da variação da intensidade do máximo de fluorescência em $340 \mathrm{~nm}$, com excitação em $279 \mathrm{~nm}$. Essa fotoxidação da proteína é causada pela formação de ${ }^{1} \mathrm{O}_{2}$ e ou radicais livres formados na presença de luz por cada um dos FSs estudados. 

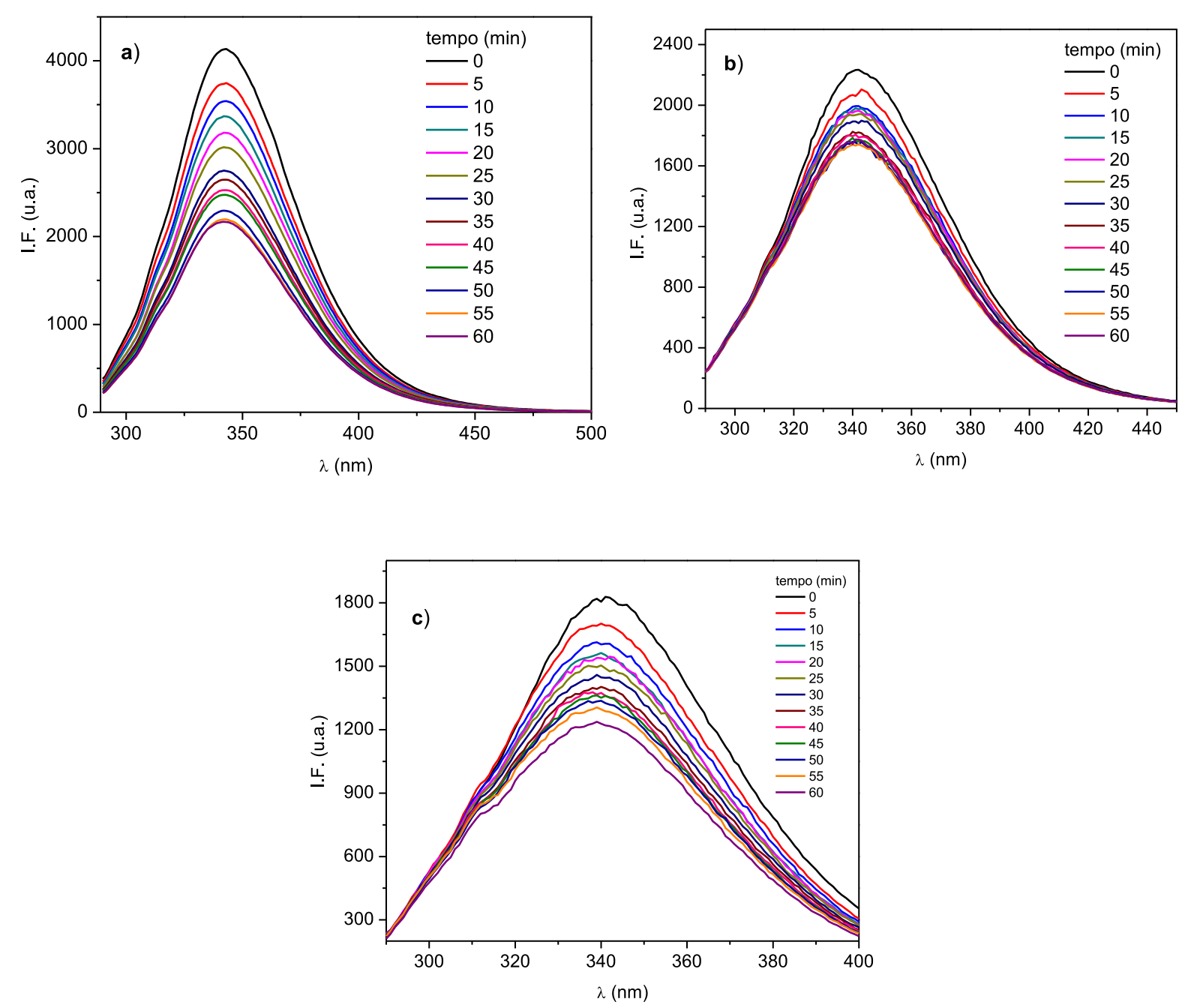

Figura 29 - Espectros de emissão de fluorescência obtidos para BSA $\left(\Lambda_{\mathrm{exc}}=279 \mathrm{~nm}\right)$ devido ao efeito fotodinâmico. Solução de BSA $\left(2 \times 10^{-3} \mathrm{~mol} \mathrm{~L}^{-1}\right)$ preparada em PBS e irradiada com LED $\left(\Lambda=630 \mathrm{~nm}, \quad I=18 \mathrm{~mW} \mathrm{~cm}{ }^{-2}, \mathrm{t}=60 \mathrm{~min}\right)$ na presença de $\mathrm{FS}\left(1 \mu \mathrm{g} \mathrm{mL} \mathrm{L}^{-1}\right) ;$ a) Hipericina, b) Photodithazine, c) Photogem.

Os valores das intensidades dos máximos de fluorescência da BSA foram utilizados para determinar o valor de In $\left(F / F_{0}\right)$ em função do tempo de irradiação. Os resultados estão mostrados na Figura 30. 

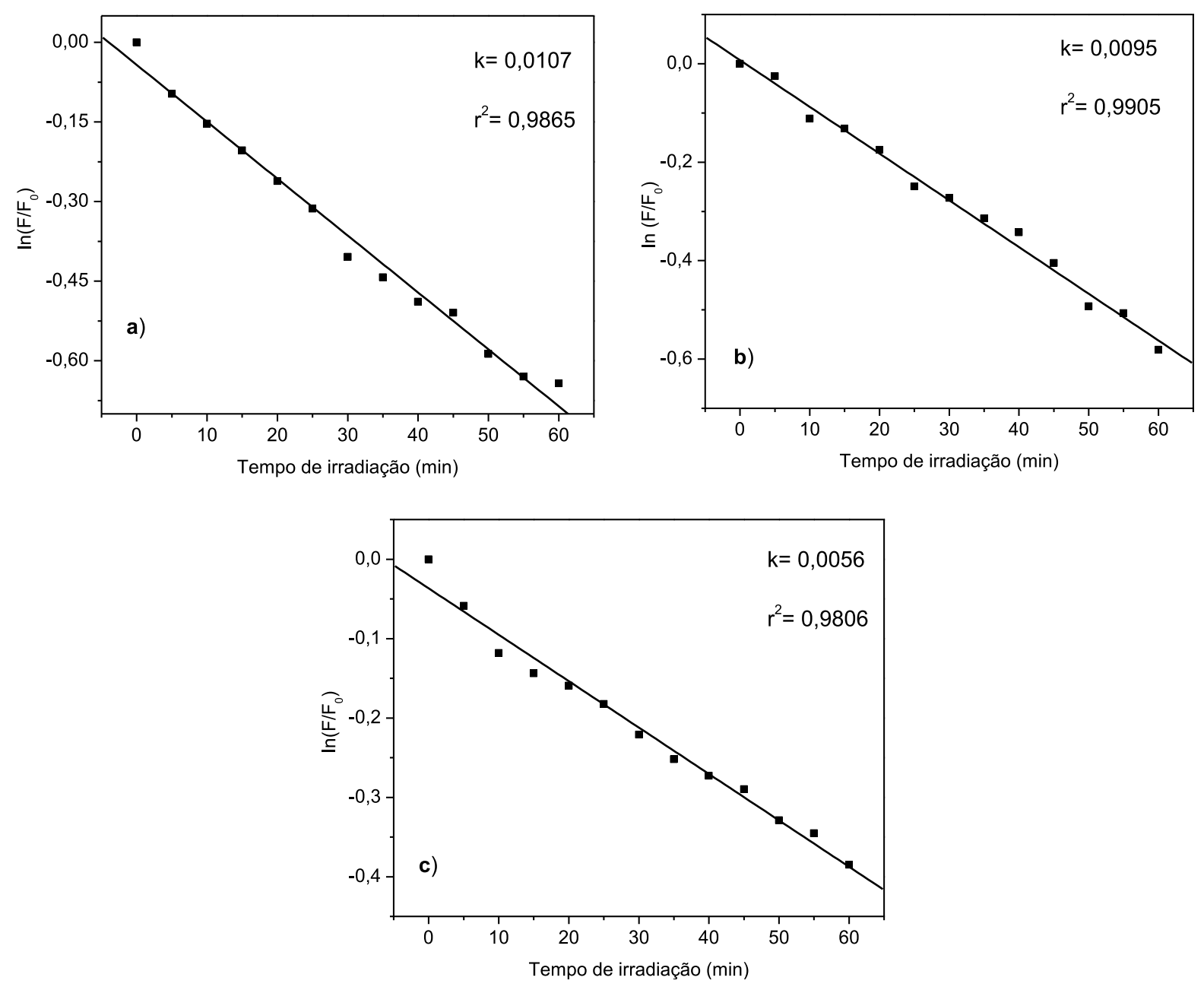

Figura 30 - Cinética de fotoxidação da BSA ocorrida na presença dos FSs: a) Hipericina; b) Photodithazine e c) Photogem. Solução de BSA BSA $\left(2 \times 10^{-3} \mathrm{~mol} \mathrm{~L}^{-1}\right)$ preparada em PBS e irradiada com LED $\left(\Lambda=630 \mathrm{~nm}, \mathrm{l}=18 \mathrm{~mW} \mathrm{~cm}{ }^{-2}, \mathrm{t}=60 \mathrm{~min}\right)$.

Verifica-se que todas as considerações citadas no item 3.6 necessárias para a determinação da constante de velocidade da reação de fotoxidação da BSA (pseudo primeira ordem) são válidas devido a relação linear entre $\ln \left(F / F_{0}\right)$ e o tempo de irradiação.

As relações de intensidades de fluorescência foram corrigidas em função da absorbância de cada FS, uma vez que cada FS apresenta absorbância distinta no comprimento de onda de irradiação. Desse modo, esses coeficientes puderam ser 
utilizados como parâmetros de comparação da eficiência fotodinâmica dos FSs na fotoxidação da BSA (Figura 31e tabela IX).
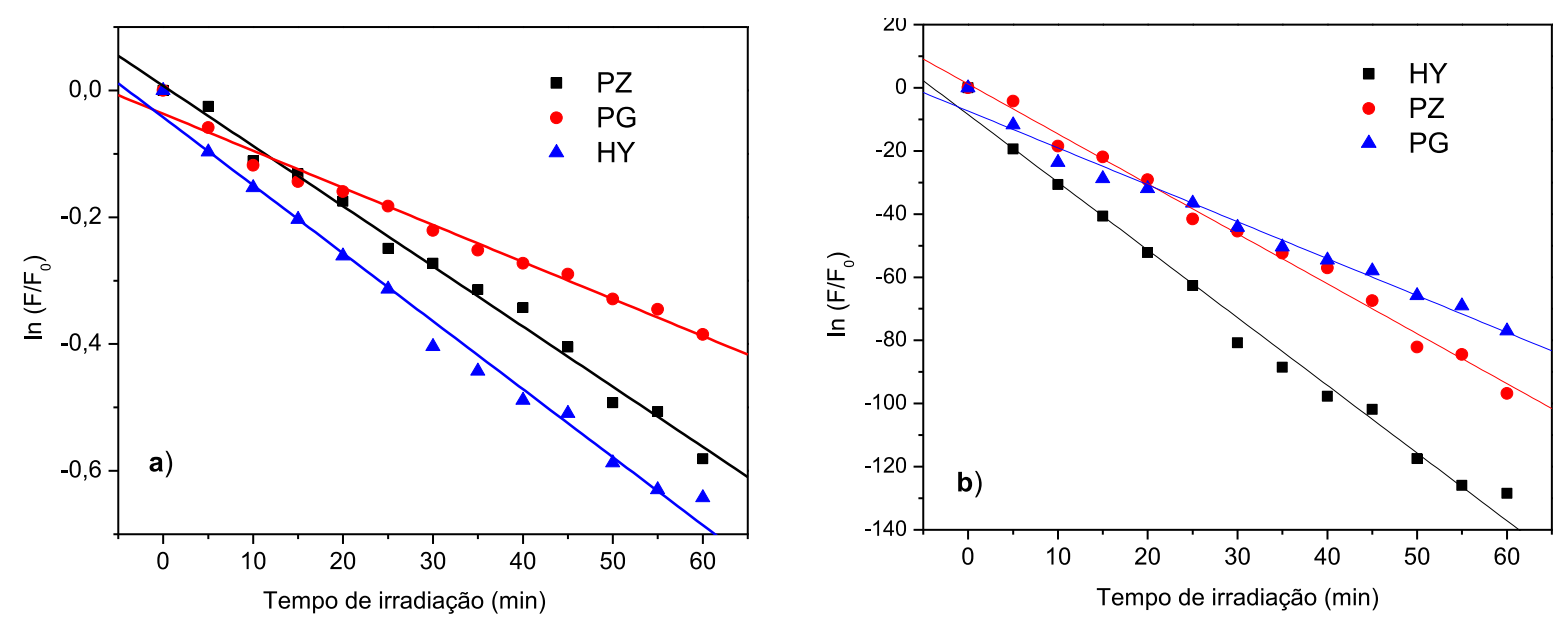

Figura 31 - a) Comparação dos coeficientes angulares (k) obtidos diretamente da relação linear entre In $\left(F / F_{0}\right)$ e o tempo de irradiação. b) Comparação dos valores das constantes de velocidade de fotoxidação da BSA $\left(k_{c}\right)$ obtidas após a correção dos valores de $k$ pelos valores das absorbâncias dos FSs no comprimento de onda de irradiação $(\lambda=630 \mathrm{~nm})$.

Tabela IX - Valores das constantes de velocidade da reação de fotoxidação de BSA $\left(2 \times 10^{-3} \mathrm{~mol} \mathrm{~L}^{-1}\right)$ na presença de $\mathrm{FS}\left(1 \mathrm{\mu g} \mathrm{mL}^{-1}\right)$ em PBS, obtidas através da irradiação das amostras com LED ( $\left.\Lambda=630 \mathrm{~nm}, \mathrm{I}=18 \mathrm{~mW} \mathrm{~cm}^{-2}, \mathrm{t}=60 \mathrm{~min}\right)$. Os ensaios foram realizados em triplicata.

\begin{tabular}{ccc}
\hline FS & $\mathbf{k}\left(10^{-3} \mathrm{~min}^{-1}\right)$ & $\mathbf{k c}\left(10^{-1} \mathbf{m i n}^{-1}\right)$ \\
\hline HY & $11 \pm 1$ & $21 \pm 3$ \\
PZ & $10 \pm 1$ & $16 \pm 1$ \\
PG & $6 \pm 1$ & $12 \pm 1$ \\
\hline
\end{tabular}

Os valores de kc mostram que a HY foi o FS mais eficiente na fotoxidação de BSA, seguida por PZ e PG, apresentando constante de fotoxidação 
aproximadamente $35 \%$ maior que a do $\mathrm{PZ}$ e $83 \%$ maior que a do PG. A maior eficiência da HY em fotoxidar BSA comparada ao PZ e ao PG pode estar relacionada ao tempo de vida do FS no estado triplete excitado, sugerindo que a $\mathrm{HY}$ tem maior probabilidade de interação com o oxigênio molecular. Sendo assim, a HY apresentaria um rendimento quântico de geração de oxigênio singlete maior do que o PZ e o PG, o que resulta em uma maior eficiência fotodinâmica.

A fotoxidação de proteínas deve-se principalmente à fotoxidação de suas cadeias laterais devido à presença de aminoácidos suscetíveis à fotoxidação como cisteína, histidina, triptofano, entre outros. No entanto, trata-se de um processo bastante complexo, onde vários fatores podem interferir na cinética de reação, tais como alterações conformacionais que acontecem na proteína devido à ligação do FS ou a destruição de outros aminoácidos suscetíveis à fotoxidação. Essas alterações de conformação tanto podem impedir a exposição de aminoácidos, protegendo-os da fotoxidação, quanto podem estar expondo os resíduos ao ataque $^{150}$.

A metodologia empregada neste trabalho, baseada na supressão da fluorescência da BSA devido a fotoxidação da proteína, foi possível graças às propriedades óticas particulares dos resíduos de triptofano e tirosina. Em geral, a fluorescência das proteínas como, por exemplo, na albumina, é dominada pela emissão do triptofano, pois o coeficiente de extinção molar do indol desse resíduo é aproximadamente cinco vezes maior que o fenil da tirosina. Embora a tirosina seja altamente fluorescente em solução, sua emissão é muito menor em proteínas devido ao efeito de supressão por grupos vizinhos, uma vez que este resíduo é um fluorofóro natural bastante sensível à polaridade de sua vizinhança ${ }^{150}$. 
Um estudo feito por Silvester et al ${ }^{69}$ forneceu indícios do que poderia estar ocorrendo durante o processo de fotoxidação da BSA. Os autores verificaram que a fotoxidação por hematoporfirina ocorre em dois diferentes sítios específicos da proteína: nos resíduos triptofano 135 e ou triptofano 214 e no resíduo cisteína 34 . A fotoxidação da cisteína 34 gera moléculas radicalares. Acredita-se que, a formação desses radicais ocorra pela "transferência de dano" através da proteína, iniciando-se no sítio de ligação do FS e propagando-se através de transferência de elétrons até o resíduo cisteína 34 . Foi observada também a formação de radicais em carbonos terciários no triptofano que coincide com a diminuição da fluorescência da BSA. A formação desses radicais a partir do triptofano poderia estar ocorrendo via transferência de elétrons. Verificou-se então que a fotoxidação da BSA foi devida tanto ao mecanismo de transferência de energia (tipo II) como também ao mecanismo de transferência de elétrons (tipo I).

Nos seres vivos, lipídeos insaturados e proteínas são os principais constituintes das membranas biológicas, sendo alvos subcelulares destruídos na TFD. Portanto, estas reações ocasionam alterações na permeabilidade celular, ruptura e vazamento do conteúdo celular, resultando na morte das células.

\subsection{Determinação dos coeficientes de partição dos FSs}

No processo de planejamento e otimização dos fármacos, é necessário conhecer seu comportamento nos vários compartimentos farmacológicos em que se encontrará. Isto se relaciona ao compartimento de partição do composto entre a água, que está presente em praticamente todo meio biológico e os vários tipos de 
lipídeos encontrados, por exemplo, na membrana celular ou como parte da mistura complexa de proteínas do sangue, isto é, do balanço hidrofílico/lipofílico do fármaco. Uma medida simples, in vitro, deste comportamento é o logaritmo do coeficiente de partição do composto entre dois solventes, que normalmente são água e 1-octanol.

Neste estudo, os coeficientes de partição log P dos FSs foram determinados para se avaliar o caráter hidrofóbico (lipofílico) desses fármacos. A tabela $X$ apresenta os valores de log P para Hipericina, Photogem e Photodithazine.

Tabela X - Coeficientes de partição obtidos para os fotossensibilizadores. Os ensaios foram realizados em triplicata.

\begin{tabular}{cc}
\hline Fotossensibilizador & $\log \mathbf{P} \pm \boldsymbol{\sigma}$ \\
\hline Hipericina & $1,20 \pm 0,02$ \\
Photodithazine & $-0,62 \pm 0,03$ \\
Photogem & $-0,9 \pm 0,2$ \\
\hline
\end{tabular}

Em termos quantitativos, o caráter hidrofílico está associado a pouca distribuição do FS no octanol, com log $\mathrm{P}<0$ para estes compostos. $\mathrm{O}$ caráter lipofílico é atribuído aos compostos com $\log P>+1,5$, e as substâncias que possuem valores intermediários são consideradas anfifílicas ${ }^{89}$.

A Hipericina foi o fotossensibilizador que apresentou um valor positivo de coeficiente de partição, portanto é o FS de maior lipofilicidade e por conseqüência, é o fármaco com maior afinidade e de maior mobilidade entre os lipídios constituintes 
da membrana celular entre os FSs estudados. Já o PZ e o PG podem ser considerados hidrofílicos possuem log $\mathrm{P}<0$.

O coeficiente de partição de um FS é a principal característica do sensibilizador a ser considerada no estudo da sua interação com as membranas celulares, uma vez que a permeabilidade de uma molécula através das membranas celulares pode ser estimada através de seu coeficiente de partição: quanto maior a lipofilicidade da molécula, maior é o seu coeficiente de partição e mais rápida será a sua difusão através das membranas. Os FSs ao se difundirem no meio celular, em geral passam através das células atravessando as membranas, e não pelos espaços intercelulares, que são diminutos e permitem apenas a passagem de moléculas de água, sais e compostos de baixo peso molecular. A membrana celular é uma estrutura dinâmica, mutável e adaptável à passagem de diferentes substâncias e os organismos são sucessões de fases lipídicas e aquosas, deste modo um coeficiente de partição muito elevado ou muito baixo, pode constituir um obstáculo à difusão generalizada da droga ${ }^{78}$. Assim, o balanço hidrofílico/lipofílico do FS desempenha um papel muito importante na determinação da sua localização na célula, e conseqüentemente, do seu sítio de ação

\subsection{Fotoxidação do ácido úrico}

O ácido úrico é um excelente captador de oxigênio singlete usado como dosímetro químico para a determinação quantitativa da ação fotodinâmica de FSs ${ }^{80}$.

A Figura 32 apresenta o espectro de absorção ótica do ácido úrico $10 \mu \mathrm{g} \mathrm{mL} \mathrm{L}^{-1}$ em SDS $2 \%$. 


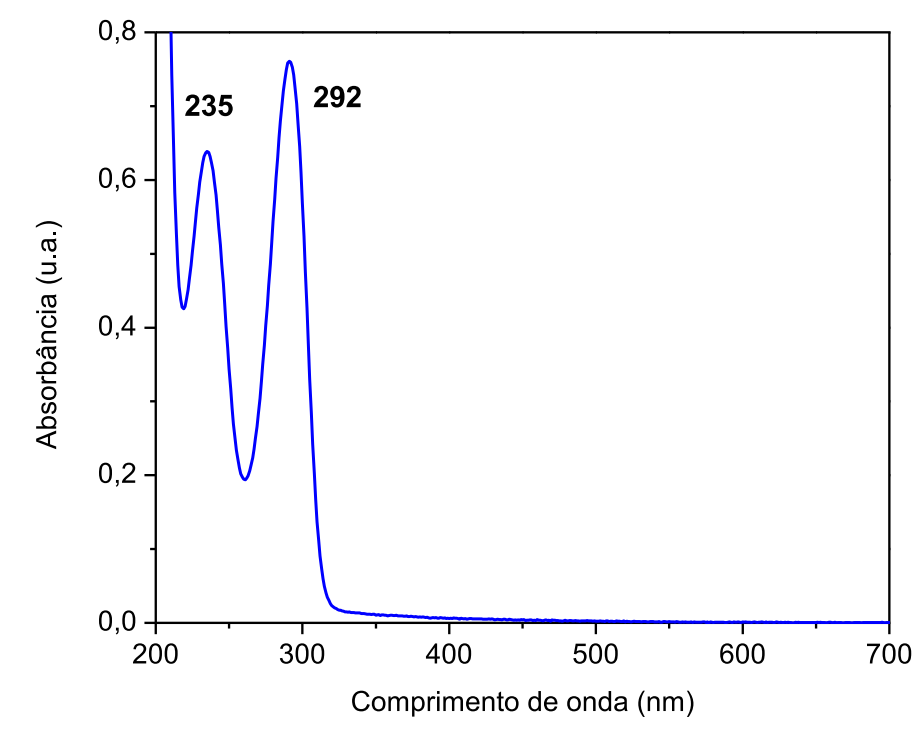

Figura 32 - Espectro de absorção ótica do ácido úrico $10 \mu \mathrm{g} \mathrm{mL}^{-1} \mathrm{em} \mathrm{SDS} \%$.

O ácido úrico apresenta duas bandas de absorção ótica em 235 e 292 nm, e não absorve em 630 nm, comprimento de onda da irradiação com LED vermelho, o que garantiu que a interação com a luz fosse restrita aos FSs nos experimentos de determinação do coeficiente de atividade fotodinâmica. Foram obtidos espectros de absorção ótica de uma solução de PZ $5 \mu \mathrm{g} \mathrm{mL}^{-1}$ e ácido úrico $10 \mu \mathrm{g} \mathrm{mL}^{-1}$ em SDS $2 \%$ após irradiação com LED no comprimento de onda $630 \mathrm{~nm}$ durante $20 \mathrm{~min}$. A Figura 33 mostra a variação da absorbância da banda do ácido úrico ( $\Delta_{\mathrm{AU}} 292 \mathrm{~nm}$ ) e do Photodithazine ( $\Delta_{\mathrm{PZ}} 404 \mathrm{~nm}$ ) em função do tempo de irradiação. 


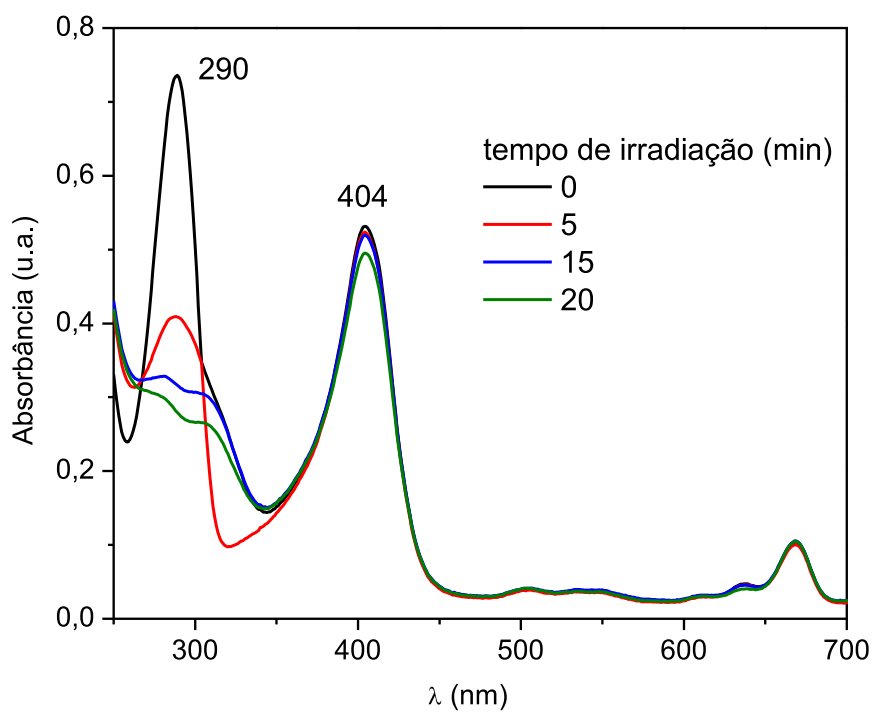

Figura 33 - Variação espectral da mistura Photodithazine $5 \mu \mathrm{g} \mathrm{mL}{ }^{-1}$ e ácido úrico $10 \mu \mathrm{g} \mathrm{mL}^{-1}$ preparada em SDS $2 \%$, irradiada com LED $\left(\Lambda=630 \mathrm{~nm}, \mathrm{l}=18 \mathrm{~mW} \mathrm{~cm}^{-2}, \mathrm{t}=20 \mathrm{~min}\right)$.

Observa-se que a banda em $290 \mathrm{~nm}$ foi a banda mais facilmente afetada da mistura após a irradiação, enquanto a banda do PZ em 404 nm sofreu uma variação muito pequena, que pode ser melhor visualizada na Figura 34, que evidencia os picos em $290 \mathrm{~nm}$ e em $404 \mathrm{~nm}$.
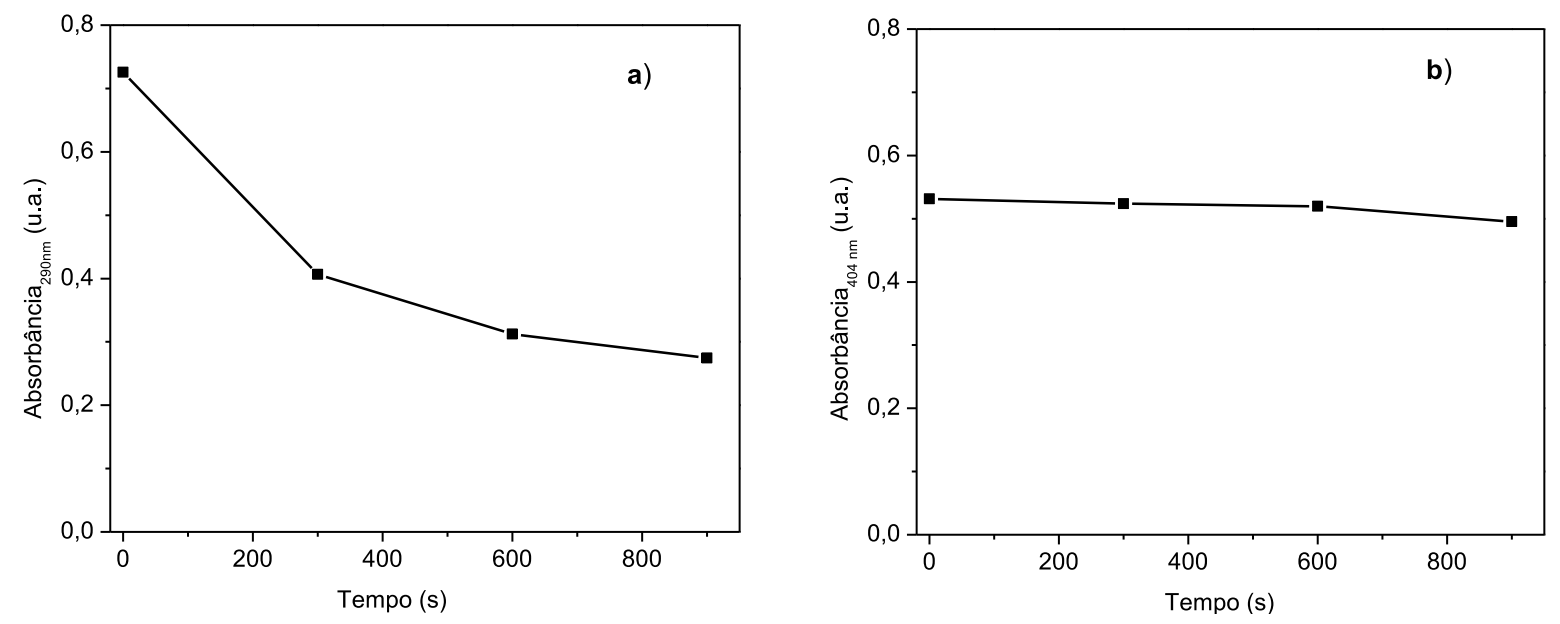

Figura 34 - Variação da absorbância e função do tempo de irradiação em segundos, em a) do ácido úrico em $290 \mathrm{~nm}$ e b) do Photodithazine em $404 \mathrm{~nm}$. 
Observa-se na Figura 34 a banda de absorção em 290 nm teve um decréscimo de $62 \%$ na sua intensidade, enquanto a intensidade da banda do Photodithazine em $404 \mathrm{~nm}$ diminui apenas 7\%, ambas após $900 \mathrm{~s}$ de irradiação. Esse pequeno dano que o FS sofreu do efeito fotodinâmico é conhecido como fotodegradação, já discutido no item 4.5.2.

Essa metodologia para a determinação e comparação da atividade fotodinâmica de diferentes fotossensibilizadores foi proposta por Fischer et al. ${ }^{80} \mathrm{e}$ estabelece um tempo de irradiação de 300 s, de modo a obter uma correlação linear entre a variação da absorbância do ácido úrico e a concentração do FS.

Visando facilitar a comparação do efeito fotodinâmico dos três FSs estudados, a Figura 36 apresenta os resultados obtidos na fotoxidação do ácido úrico na presença dos FSs após irradiação. 

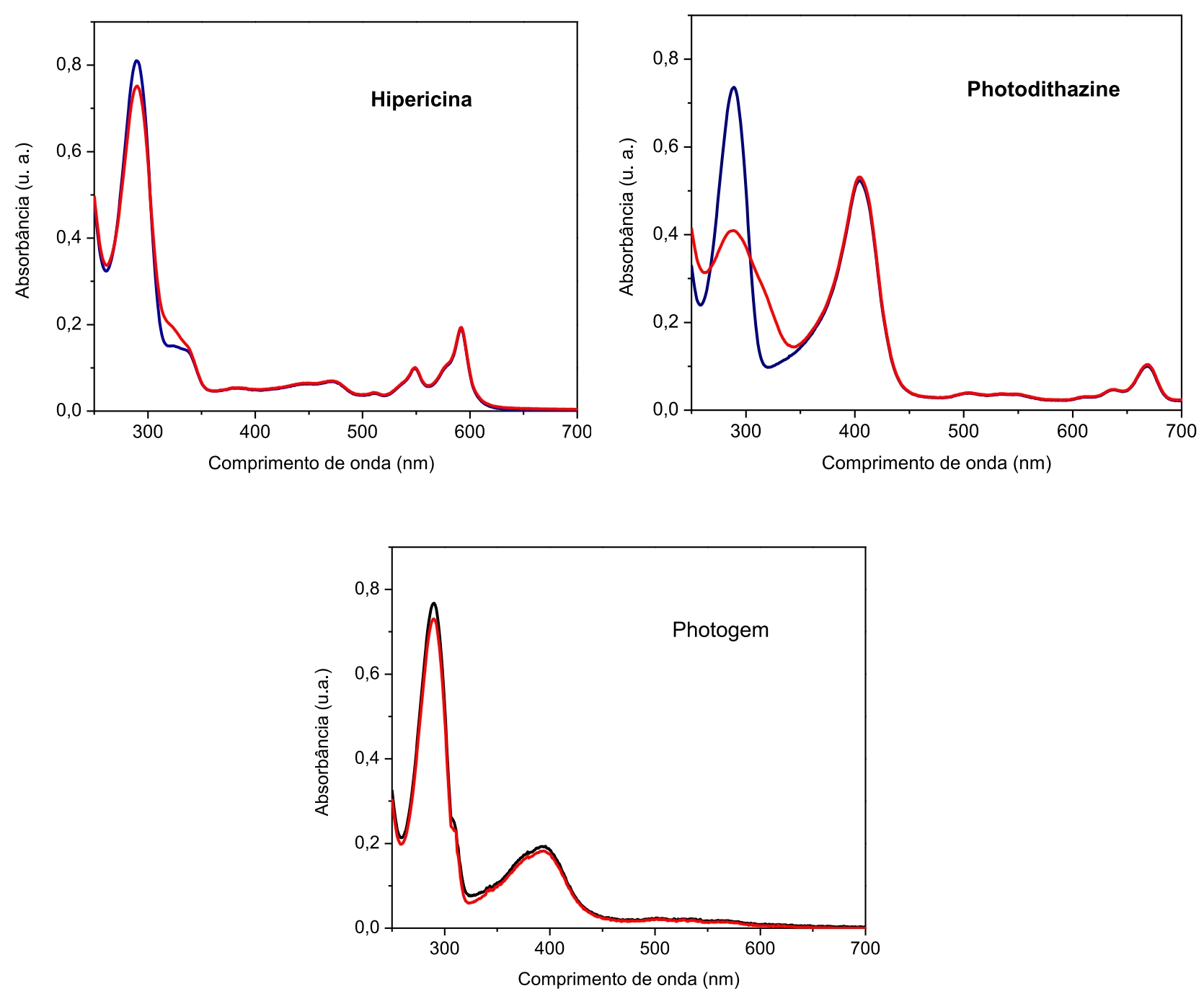

Figura 35 - Espectros de absorção ótica antes e após irradiação com LED $(\Lambda=630 \mathrm{~nm}$, $\mathrm{I}=18 \mathrm{~mW} \mathrm{~cm}^{-2}, \mathrm{t}=300 \mathrm{~s}$ ) de uma mistura de AU $10 \mu \mathrm{g} \mathrm{mL}^{-1}$ e FS $5 \mu \mathrm{g} \mathrm{mL}^{-1}$ em SDS $2 \%$. A linha preta $(-)$ indica o espectro obtido antes da irradiação e a linha vermelha $(-)$ indica o espectro obtido após o tempo de irradiação.

Nos três casos observa-se o decréscimo da banda característica do ácido úrico em $290 \mathrm{~nm}$, indicando que em todos ocorre a reação de decomposição desta molécula pelo oxigênio singlete formado pelos FSs excitados. A partir desses resultados obteve-se uma escala de atividade fotodinâmica de acordo com a equação 17 que está apresentada na tabela XI. 
Tabela XI - Coeficientes de Atividade Fotodinâmica dos FSs correspondendo a média de três experimentos realizados em triplicata.

\begin{tabular}{cc}
\hline Fotossensibilizador & Atividade Fotodinâmica $\left(\mathbf{m}^{2} \mathbf{~ J}^{-1}\right)$ \\
\hline HY & $26 \pm 5$ \\
PZ & $12 \pm 3$ \\
PG & $7 \pm 1$ \\
\hline
\end{tabular}

Esses resultados de atividade fotodinâmica corroboram com os obtidos nos experimentos de fotoxidação de BSA e fototoxicidade em células HEp-2, Vero, B16-F10 e McCoy. Os resultados das três metodologias apontam que a Hipericina é o fotossensibilizador mais eficiente e Photogem apresentou o pior desempenho, enquanto o Photodithazine tem um comportamento intermediário.

\subsection{Determinação do rendimento quântico de fluorescência da Hipericina, Photodithazine e Photogem em etanol}

O rendimento quântico de fluorescência da HY, PZ e PG foi determinado utilizando como padrão rodamina $B\left(\Phi_{\mathrm{f}}=0,65\right.$ em etanol $\left.{ }^{88}\right)$.

Uma vez que a TFD é altamente dependente da produção de oxigênio singlete, o rendimento quântico de fluorescência é uma propriedade fotofísica de grande importância para os fotossensibilizadores. Assim, substâncias altamente fluorescentes usualmente são pouco eficientes como agentes fotodinâmicos, uma vez que é baixa a produção de estados excitados tripletes formados pelo processo de cruzamento intersistemas, o que resulta em baixos processos de transferência 
de energia entre o estado excitado triplete e o oxigênio, produzindo oxigênio triplete. Assim, os baixos valores de $\Phi_{f}$ encontrados contribuem para a formação dos estados excitados tripletes e, portanto, para a produção do oxigênio singlete.

A tabela XII apresenta os resultados de absorbância, áreas da banda de emissão bem como os rendimentos quânticos de fluorescência obtidos para cada fotossensibilizador.

Tabela XII - Resultados de absorbâncias, áreas dos espectros de emissão e rendimento quânticos de fluorescência dos FSs. Os experimentos foram realizados em triplicata.

\begin{tabular}{c|c|c|c}
\hline FS & $\begin{array}{c}\text { Absorbância no } \wedge \text { de } \\
\text { excitação }\end{array}$ & $\begin{array}{c}\text { Área da banda de } \\
\text { emissão }\left(\times 10^{3}\right)\end{array}$ & $\begin{array}{c}\Phi_{\mathrm{f}} \\
\left(\times 10^{-3}\right)\end{array}$ \\
\hline \hline HY & $0,10 \pm 0,01$ & $157 \pm 3$ & $52 \pm 8$ \\
PZ & $0,07 \pm 0,004$ & $8,74 \pm 0,02$ & $3,6 \pm 0,1$ \\
PG & $0,08 \pm 0,002$ & $2,8 \pm 0,1$ & $1,29 \pm 0,08$ \\
\hline
\end{tabular}

A HY foi o FS que apresentou o maior rendimento quântico de fluorescência dos, 14 vezes maior que o do PZ e 40 vezes maior que o PG. Apesar da diferença encontrada, os resultados quando comparados com $\circ \Phi_{f}$ da rodamina são extremamente pequenos, indicando que quando os FSs estão no estado excitado singlete não retornam para o estado fundamental por emissão de luz de uma forma efetiva. Sendo assim, deve ocorrer um cruzamento intersistema para estado triplete mais baixo. 


\subsection{Acumulação intracelular de Hipericina, Photogem e Photodithazine}

A preferência dos FSs de se acumularem em células tumorais é um dos principais fatores na eficiência da TFD, portanto o conhecimento da concentração intracelular dos FSs pode ser considerado como um fator prognóstico para a determinação dos resultados terapêuticos ${ }^{147}$.

Foram realizados ensaios com as linhagens HEp-2 e Vero para a determinação da concentração intracelular de Hipericina, Photodithazine e Potogem em diferentes tempos de incubação. Primeiramente foi obtida uma curva padrão da absorbância da BSA em função de sua concentração. A relação é linear e assim é possível, através da equação da reta obtida, estimar a concentração proteica a partir da absorbância em $750 \mathrm{~nm}{ }^{127}$. A Figura 36 apresenta a curva padrão de absorbância em 750 nm em função da concentração de BSA.

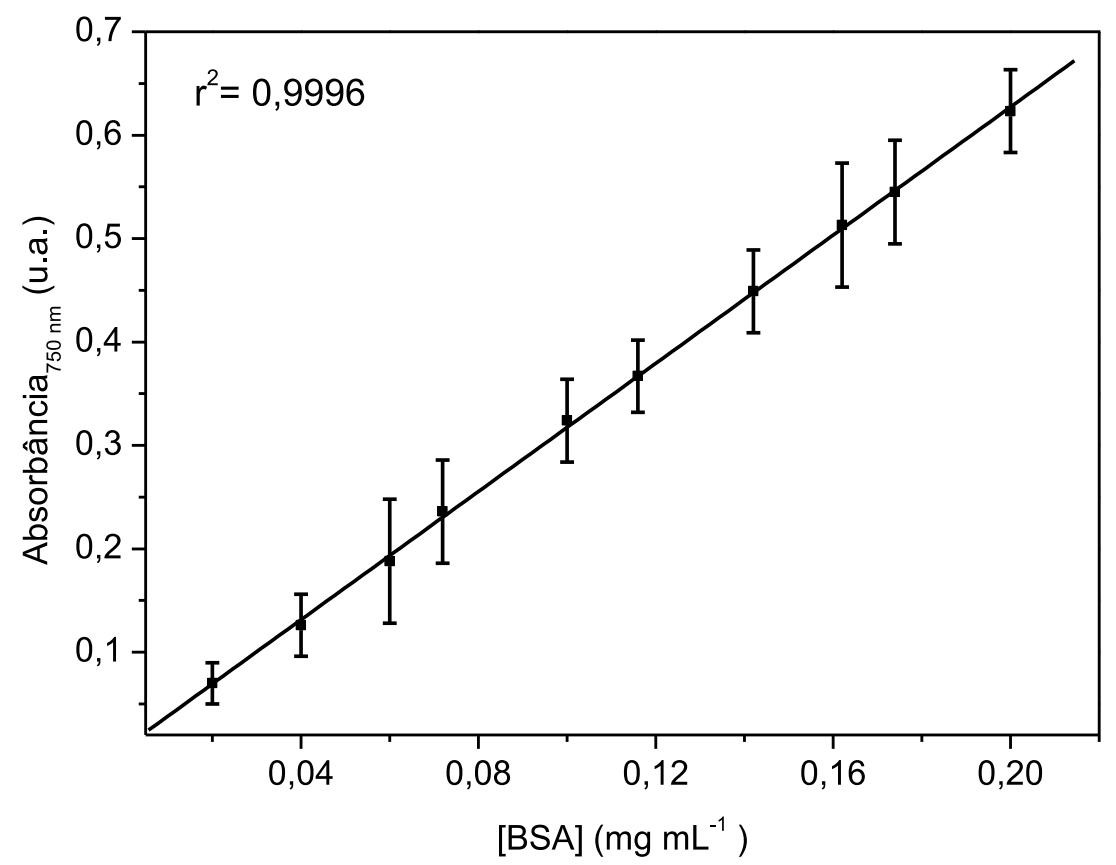

Figura 36 - Curva padrão da absorbância em $750 \mathrm{~nm}$ em função da concentração de BSA. As médias de absorbância foram obtidas de dois ensaios realizados em triplicata. 
As curvas analíticas para cada fotossensibilizador foram obtidas da determinação da fluorescência de diferentes concentrações de FS em SDS 2\%. A Figura 37 apresenta os espectros de emissão de soluções de HY e a curva analítica para a Hipericina.
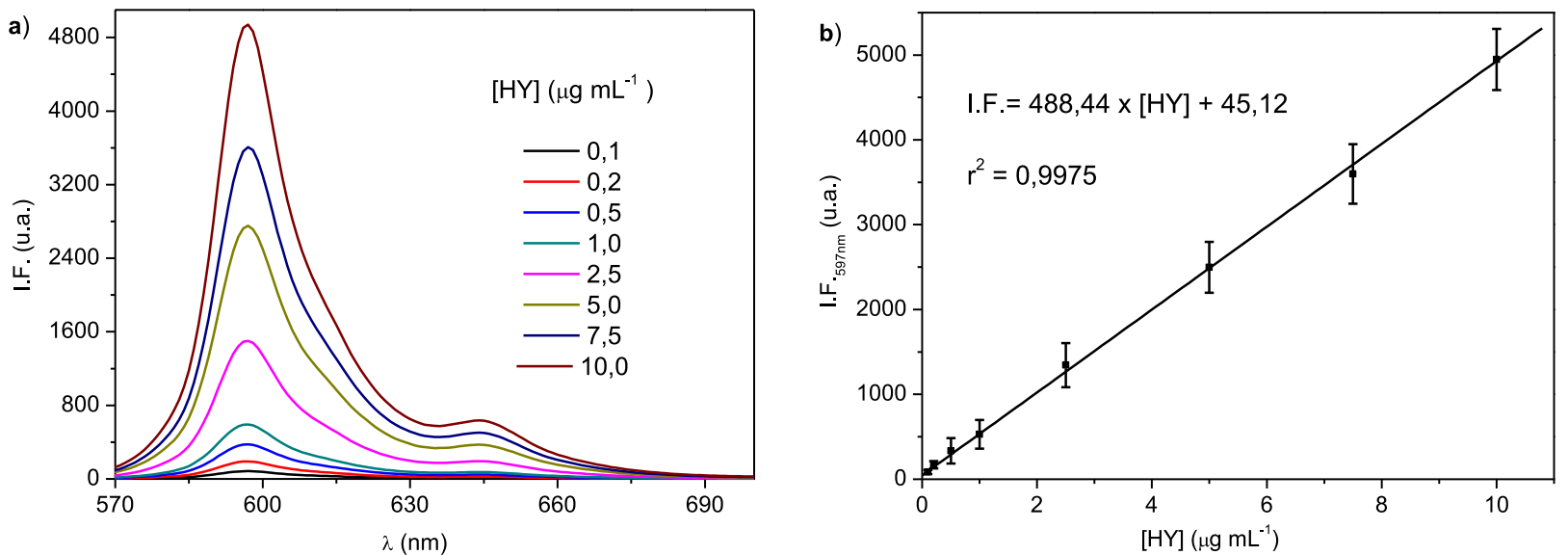

Figura 37 - a) Espectros de emissão de soluções de HY em SDS 2\% e diferentes concentrações. b) Curva analítica para a HY obtida a partir das intensidades de fluorescência em $597 \mathrm{~nm}$ com excitação em $552 \mathrm{~nm}$ da HY em SDS 2\% em diferentes concentrações. Experimentos foram realizados em triplicata.

Os espectros de emissão e a curva analítica para o Photodithazine em SDS 2\%. estão apresentados na Figura 38. 

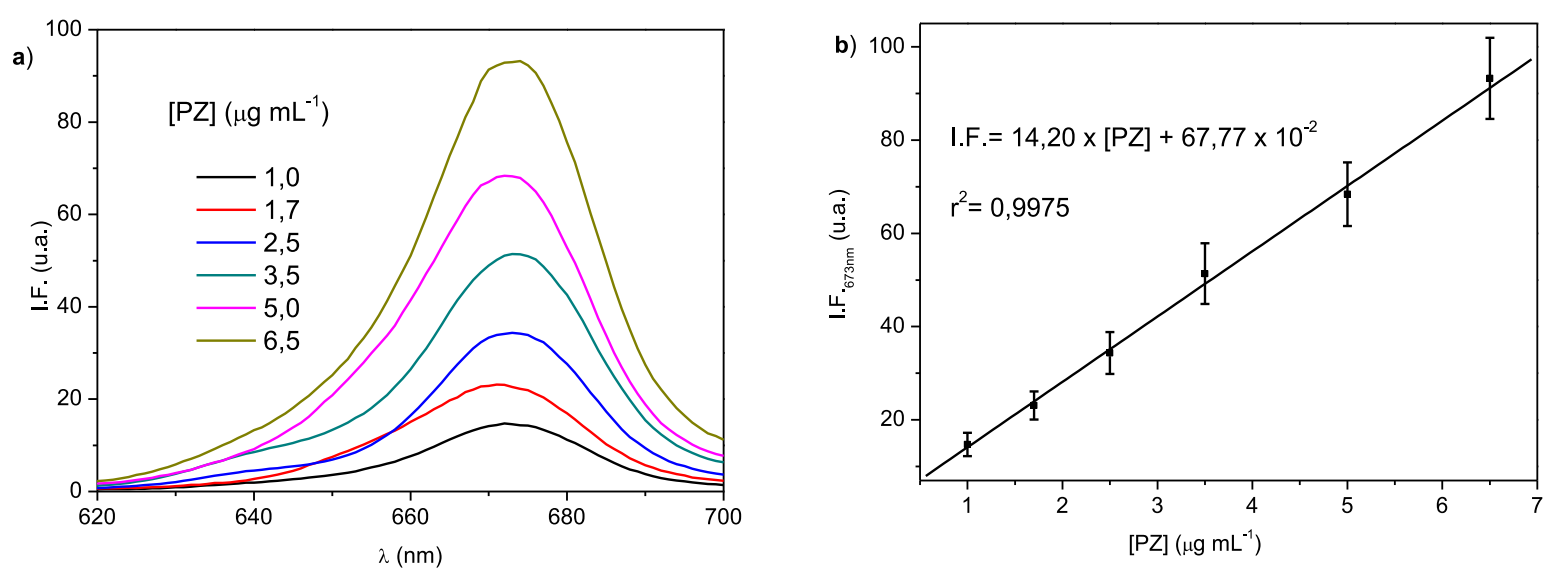

Figura 38 - a) Espectros de emissão de diferentes concentrações de soluções de PZ em $2 \%$ de SDS. b) Curva analítica do PZ obtida a partir das intensidades de fluorescência em $673 \mathrm{~nm}$ do PZ em $2 \%$ de SDS com excitação em $504 \mathrm{~nm}$. Os experimentos foram realizados em triplicata.

Os espectros de emissão e a curva analítica do Photogem em SDS $2 \%$. estão apresentados na Figura 39.
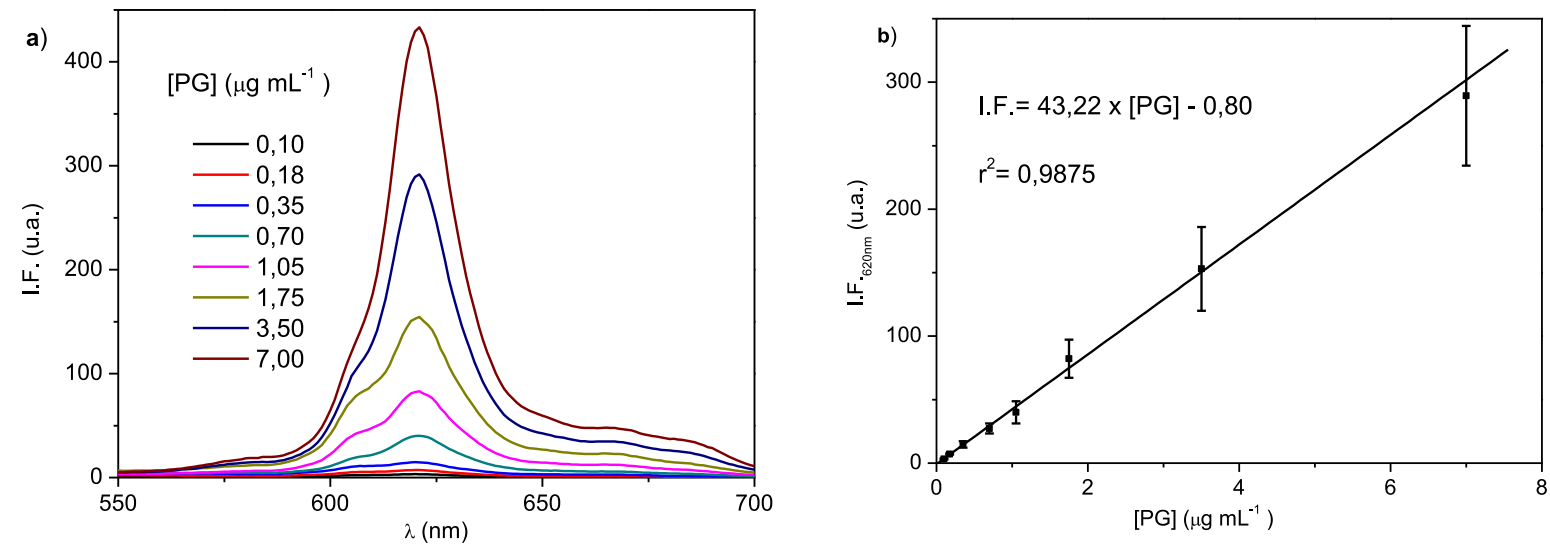

Figura 39 - a) Espectros de emissão de PG em SDS 2\% em diferentes concentrações. b) Curva analítica do PG obtida a partir das intensidades de fluorescência em $620 \mathrm{~nm}$ do PG em SDS $2 \%$ com excitação em $395 \mathrm{~nm}$. Os experimentos foram realizados em triplicata.

Todas as relações determinadas apresentaram uma boa linearidade, portanto foi possível, através da equação da reta obtida, estimar a concentração de cada FS previamente incubado com as células após a extração com SDS $2 \%$.

Com o objetivo de determinar a concentração intracelular de HY, PZ e PG em diferentes tempos de incubação, nas células HEp-2 e Vero, foram realizados 
experimentos incubando-se o FS em diferentes tempos com as linhagens. Após a extração do FS das células com SDS 2\%, a fluorescência foi obtida, a concentração do FS determinada e normalizada pela concentração de proteína, obtida pelo método de Lowry. Os resultados de acumulação de Hipericina nas células HEp-2 em função do tempo de incubação estão apresentados na Figura 40.

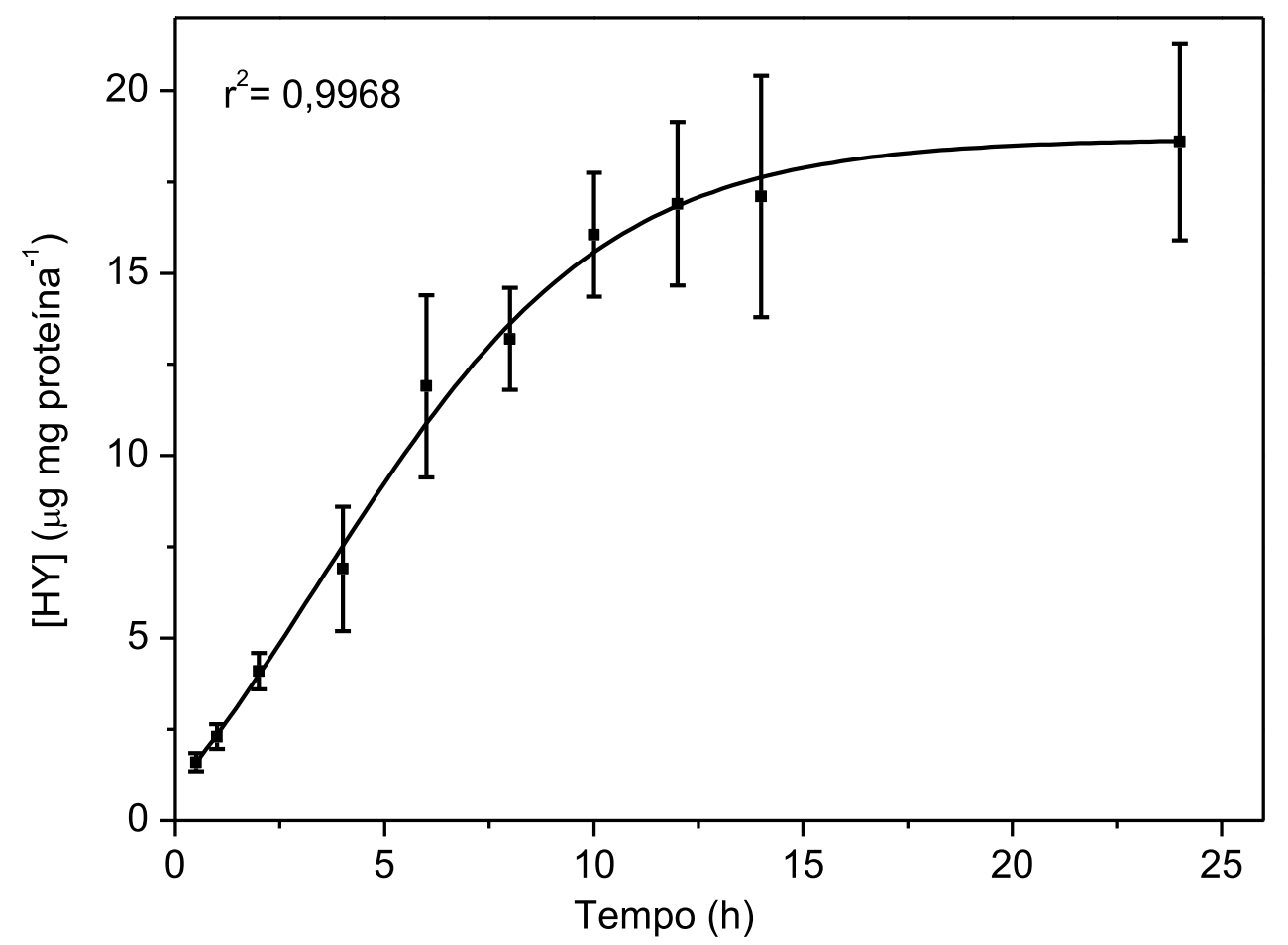

Figura 40 - Acumulação de HY em células HEp-2 normalizada pela concentração de proteína em função do tempo de incubação. Cada ponto representa a média de cinco medidas realizadas em triplicata.

Observou-se um aumento da incorporação da HY em função do tempo de incubação bastante pronunciado nas 10 horas iniciais. Após esse tempo a acumulação tende a um valor constante, sugerindo uma saturação em cerca de $18 \mu \mathrm{g}$ de HY por miligrama de proteína. A alta relação de concentração de HY pela concentração de proteína encontrada após extração é devido ao caráter lipofílico da HY, determinado nos experimentos de partição água-octanol. Essa característica da 
molécula faz com que a HY se localize principalmente na membrana plasmática. Entretanto não se pode excluir danos fototóxicos nas organelas celulares, principalmente o núcleo ${ }^{151}$.

Os valores de $\mathrm{IC}_{50}\left(\mu \mathrm{g} \mathrm{mL}^{-1}\right)$ para a HY foram obtidos em células HEp-2, após irradiação com LED 630 nm e nos tempos de incubação de 2, 4, 8, 14 e 24 h. Esses resultados estão apresentados na Figura 41.

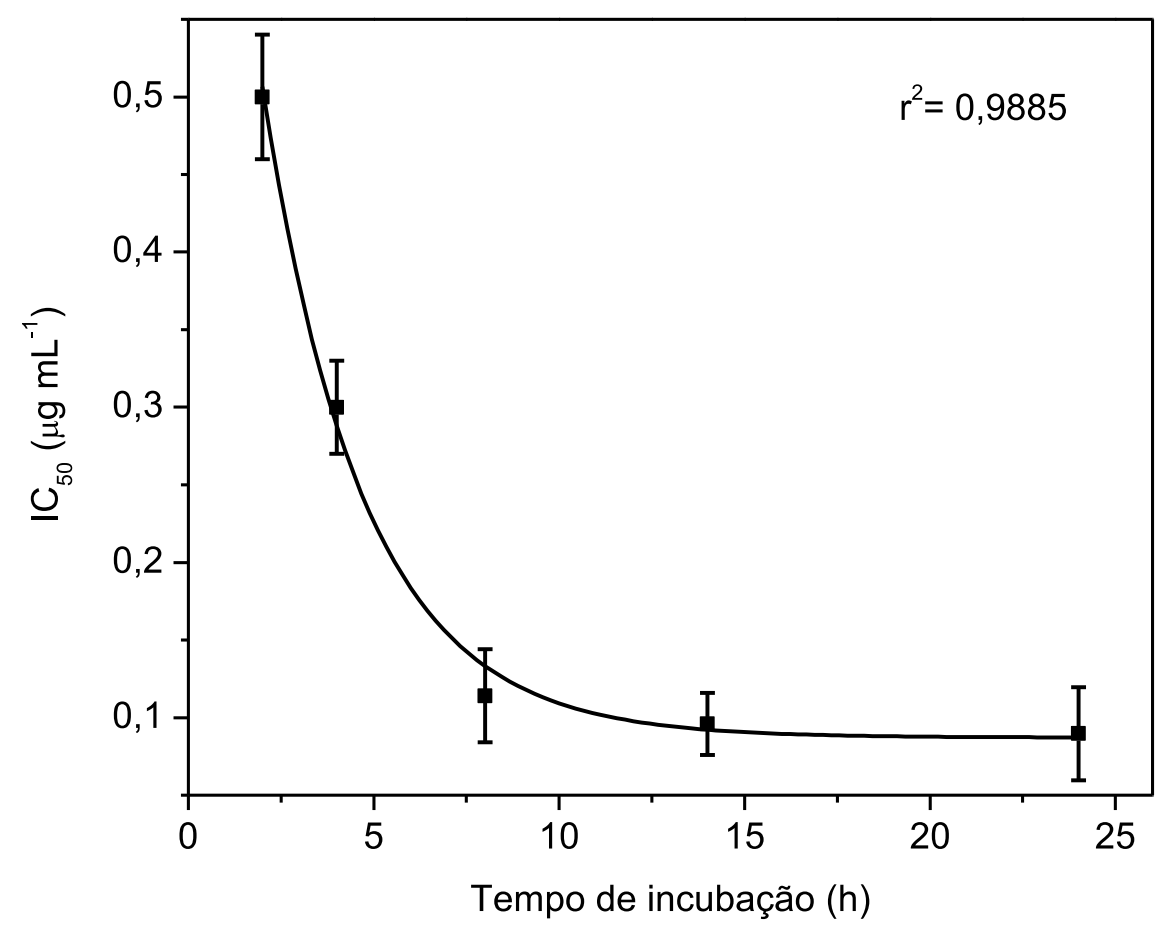

Figura $41-\mathrm{IC}_{50}$ da $\mathrm{HY}$ em função do tempo de incubação, para células HEp-2, irradiada por 4 min, LED $\Lambda=630 \mathrm{~nm}, I=18 \mathrm{~mW} \mathrm{~cm}, D=4,3 \mathrm{~J} \mathrm{~cm}^{-2}$. Cada ponto corresponde a média de 4 ensaios realizados em sextuplicata.

A Figura 41 mostra como os valores de $I_{50}$ diminuem com o tempo de incubação levando a um valor mínimo e constante após cerca de $10 \mathrm{~h}$. Os resultados de acumulação de $\mathrm{PZ}$ nas células HEp-2 em função do tempo de incubação estão apresentados na Figura 42. 


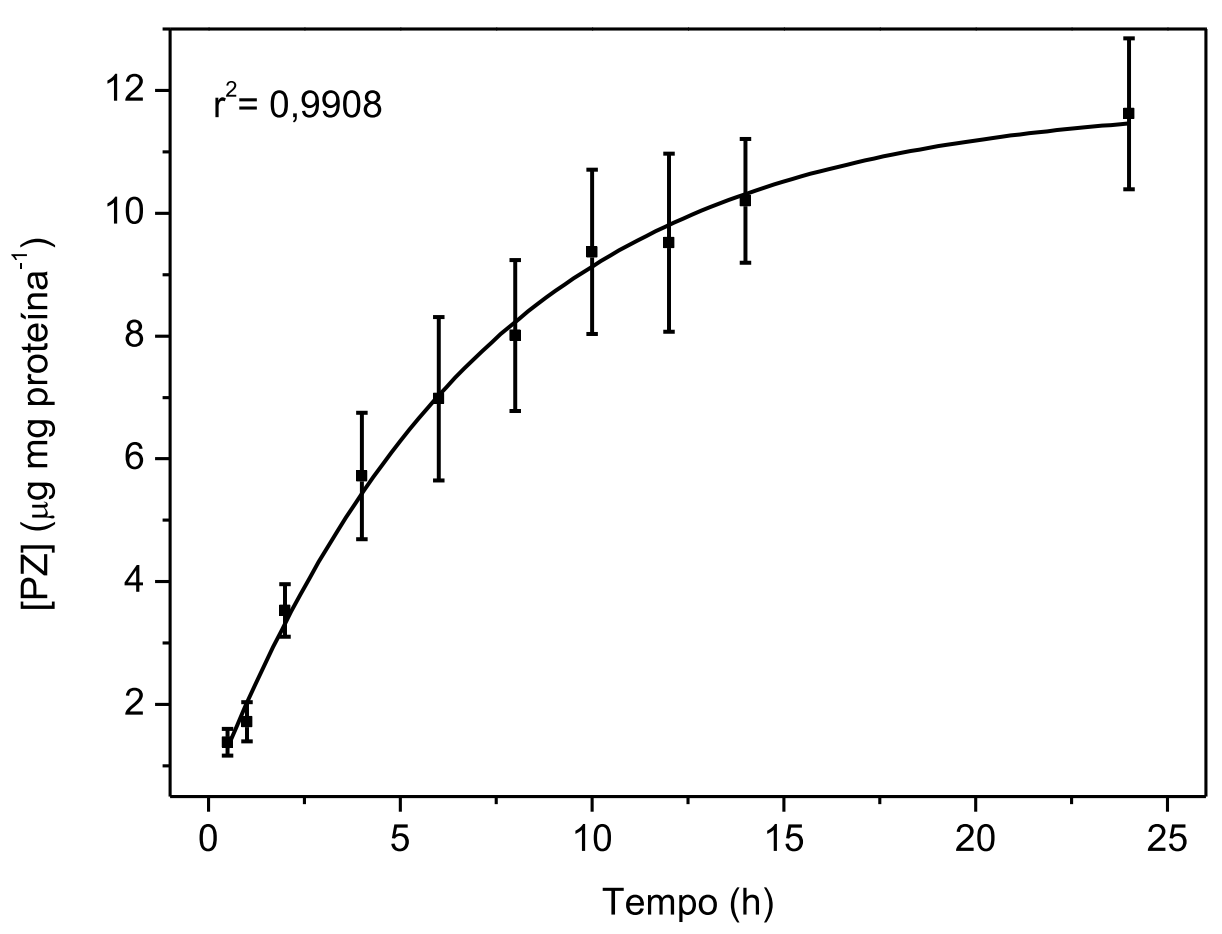

Figura 42 - Acumulação de PZ em células HEp-2 normalizada pela concentração de proteína em função do tempo de incubação Cada ponto corresponde a média de 4 ensaios realizados em sextuplicata. Cada ponto representa a média de cinco medidas realizadas em triplicata.

Pode-se observar na Figura 43 que esse derivado solúvel de clorina tem acumulação mais lenta e não atinge saturação completa mesmo após $24 \mathrm{~h}$ de incubação. Entretanto, após cerca de 15 h, um tempo superior ao encontrado para a HY, a quantidade de FS incorporado tende a ficar constante. Esses resultados corroboram com os resultados de lipofilicidade do PZ, que é uma molécula menos lipofílica do que a HY.

Os valores de $\mathrm{IC}_{50}\left(\mu \mathrm{g} \mathrm{mL}^{-1}\right)$ para o $\mathrm{PZ}$ em células HEp-2, foram obtidos após irradiação com LED $632 \mathrm{~nm}$ em tempos de incubação de 2-24 h e estão apresentados na Figura 43. 


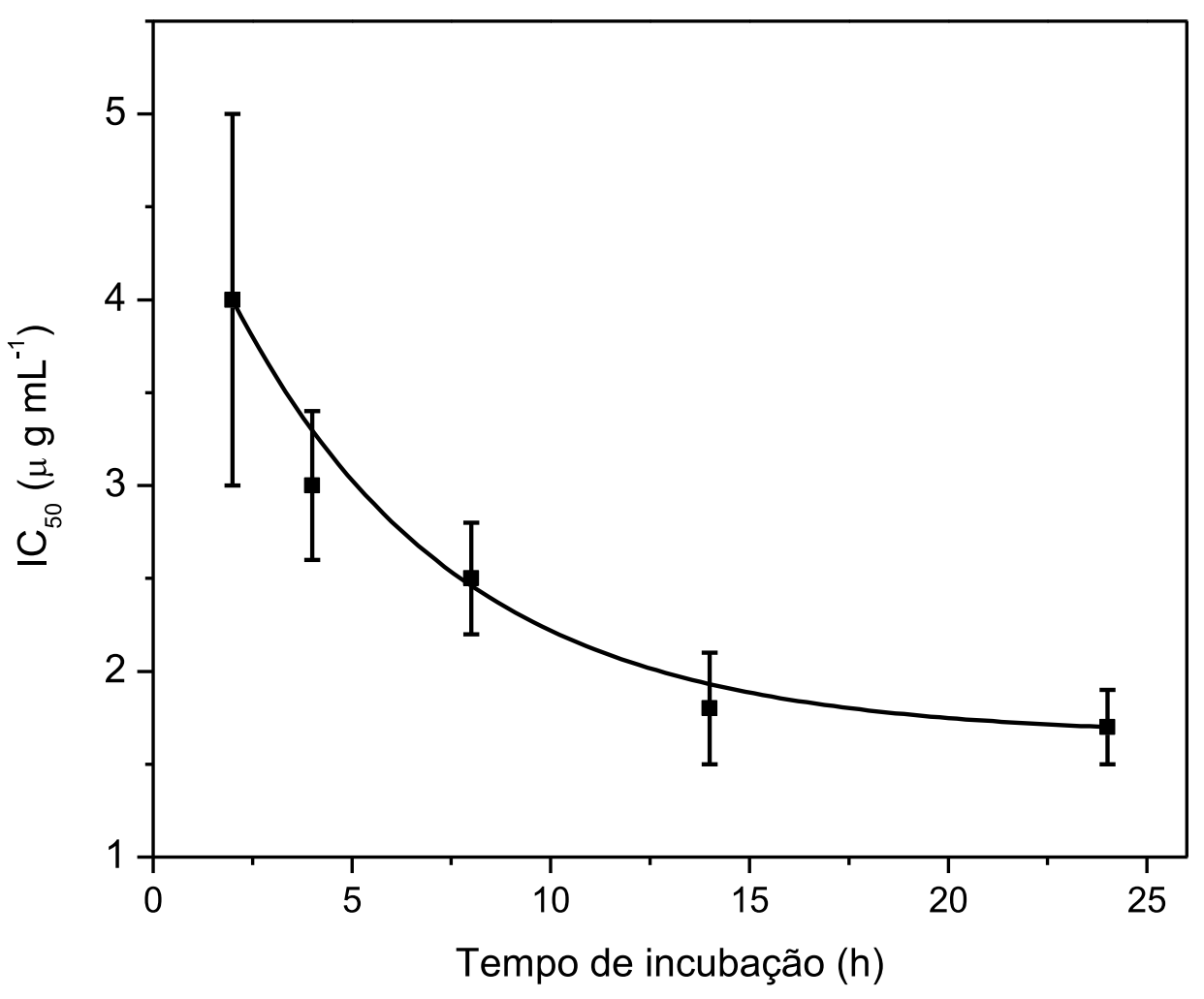

Figura $43-\mathrm{IC}_{50}$ do PZ em função do tempo de incubação, para células HEp-2, irradiada por 4 min, LED $\Lambda=630 \mathrm{~nm}, I=18 \mathrm{~mW} \mathrm{~cm}{ }^{-2}, D=4,3 \mathrm{~J} \mathrm{~cm}^{-2}$. Cada ponto corresponde a média de 3 ensaios realizados em sextuplicata.

Pode-se observar da figura acima que o decréscimo nos valores de $I C_{50}$ é mais lento com o aumento no tempo de incubação, resultado semelhante ao obtido para a acumulação desse FS, pois após cerca de $15 \mathrm{~h}$ de incubação não há mais acumulação significativa e portanto não há mais alteração no $\mathrm{IC}_{50}$.

Os resultados de acumulação do Photogem nas células HEp-2 em função do tempo de incubação estão apresentados na Figura 44. 


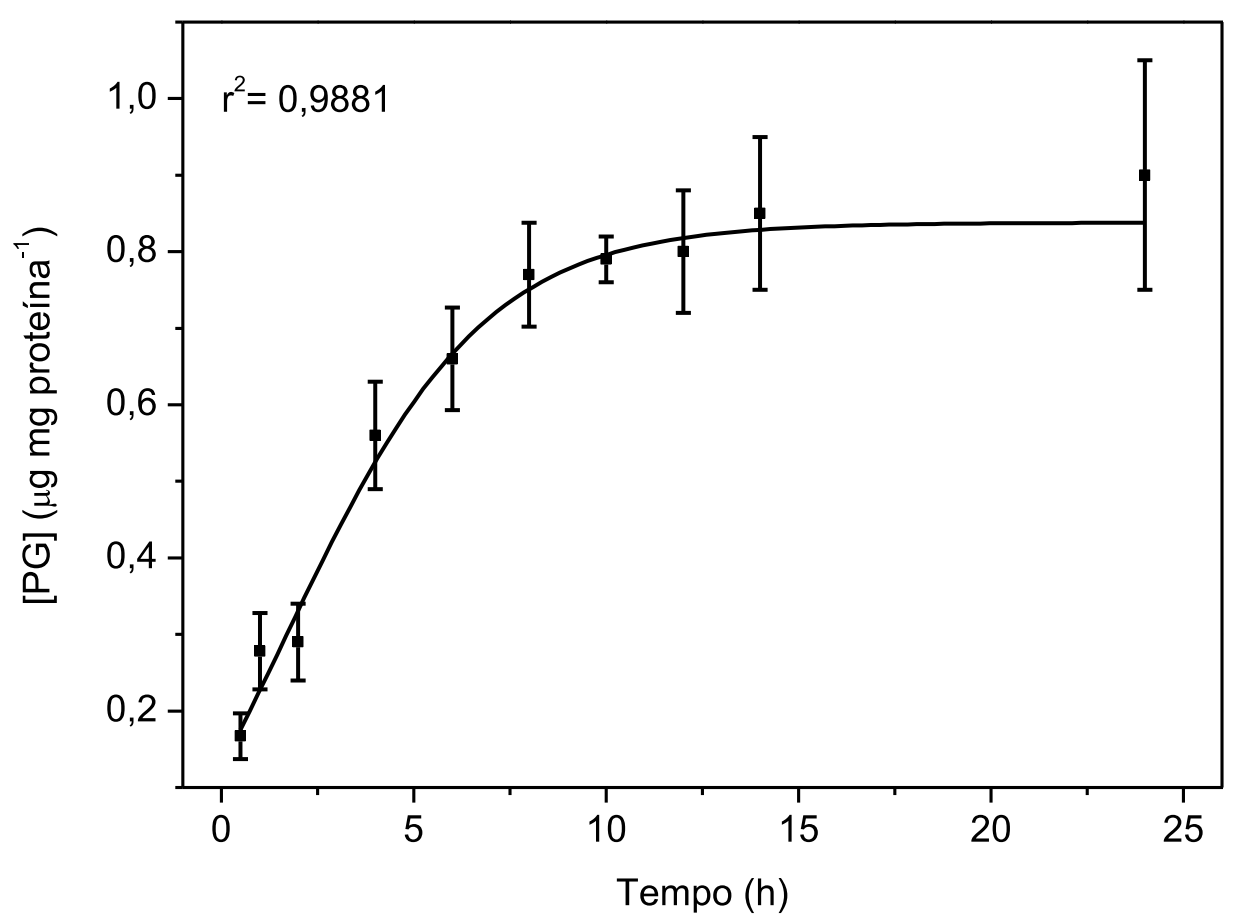

Figura 44 - Acumulação de PG em células HEp-2 normalizada pela concentração de proteína em função do tempo de incubação. Cada ponto representa a média de cinco medidas realizadas em triplicata.

O tempo necessário para saturar a acumulação de PG nas células parece ser em torno de $10 \mathrm{~h}$ onde a curva parece chegar à saturação. Outra informação relevante é a diferença de concentração de PG que se acumula quando comparada a do PZ e da Hipericina. A partir desses resultados pode-se estimar que $P Z$ acumula-se cerca de 15 vezes mais que PG e que HY acumula-se 20 vezes mais que Photogem.

Um dos requisitos para selecionar um FS é a sua capacidade de se acumular na célula, portanto HY, dentre os FSs estudados é o que se acumula em maior quantidade dentro das células.

A Figura 45 apresenta os valores de $\mathrm{IC}_{50}\left(\mu \mathrm{g} \mathrm{mL} \mathrm{m}^{-1}\right)$ para o $\mathrm{PZ}$ em células HEp-2 irradiadas com LED após incubação com esse FS por 2-24 h. 


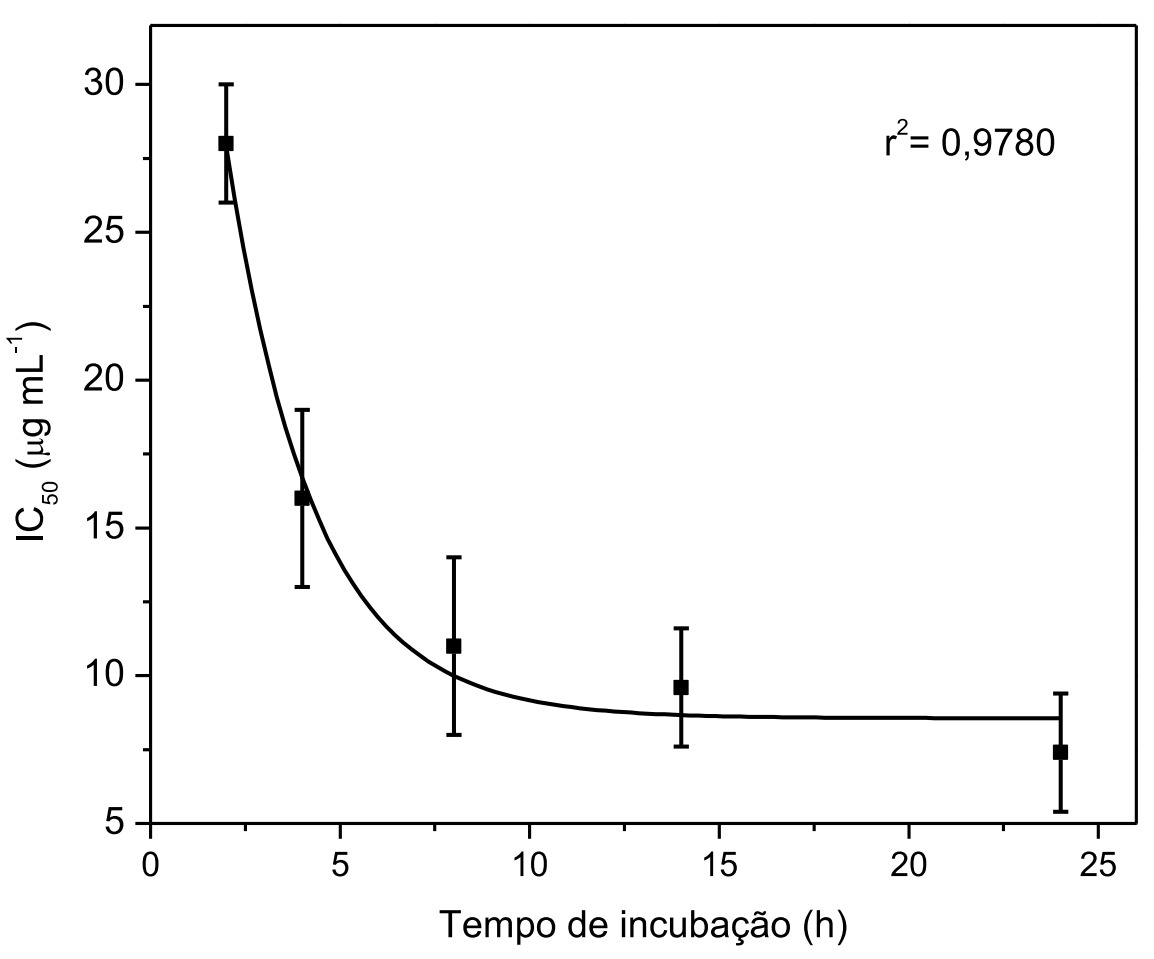

Figura $45-\mathrm{IC}_{50}$ do $\mathrm{PG}$ em função do tempo de incubação, para células HEp-2, irradiada por 4 min, LED $\Lambda=630 \mathrm{~nm}, I=18 \mathrm{~mW} \mathrm{~cm}^{-2}, \mathrm{D}=4,3 \mathrm{~J} \mathrm{~cm}^{-2}$. Cada ponto corresponde a média de 3 ensaios realizados em sextuplicata.

Na Figura 45 observa-se um decaimento mais rápido do $\mathrm{IC}_{50}$ do que para o PZ. Os valores encontrados de $\mathrm{IC}_{50}$ do $\mathrm{PG}$ foram os mais altos dentre os obtidos para os três FSs estudados, indicando a HY como o FS com a melhor atividade fototóxica.

A Figura 46 evidencia a diferença de acumulação da Hipericna, Photodithazine e Photogem em células HEp-2 em função do tempo de acumulação. 


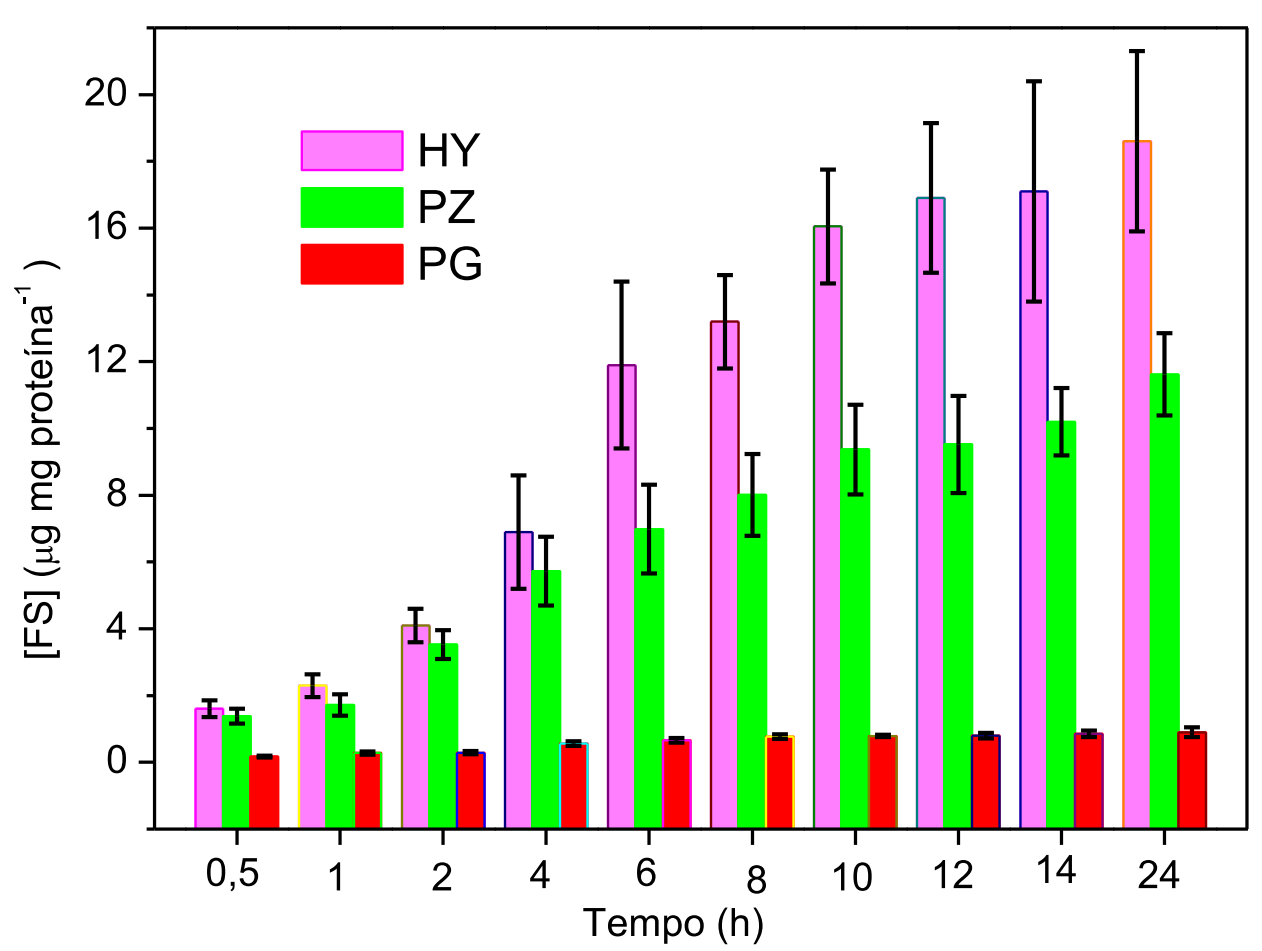

Figura 46 - Concentração da Hipericina, Photodithazine e Photogem acumulada em células HEp-2 normalizada pela proteína em função do tempo de incubação.

É evidente a drástica diferença de acumulação intracelular entre HY, PZ e PG na linhagem HEp-2. Após $2 \mathrm{~h}$ de incubação é cerca de 20 vezes maior o potencial de acumulação da HY e em 4 h cerca de 12 vezes, se comparado ao do PG. Esse fato pode ser explicado pela alta lipofilicidade da HY, muito maior que do PG (ver tabela III). Observa-se uma clara correlação entre a capacidade da Hipericina se ligar fortemente à membrana celular e organelas sendo esses os principais alvos de fotoativação da Hipericina. Dessa forma é possível correlacionar esse resultado com a eficiência fotodinâmica da HY comparada à do PZ e Photogem.

Ensaios semelhantes aos realizados com a linhagem HEp-2 foram feitos com a linhagem Vero. A Figura 47 apresenta os resultados de acumulação de HY 
normalizada pela concentração de proteína das células Vero em função do tempo de incubação.

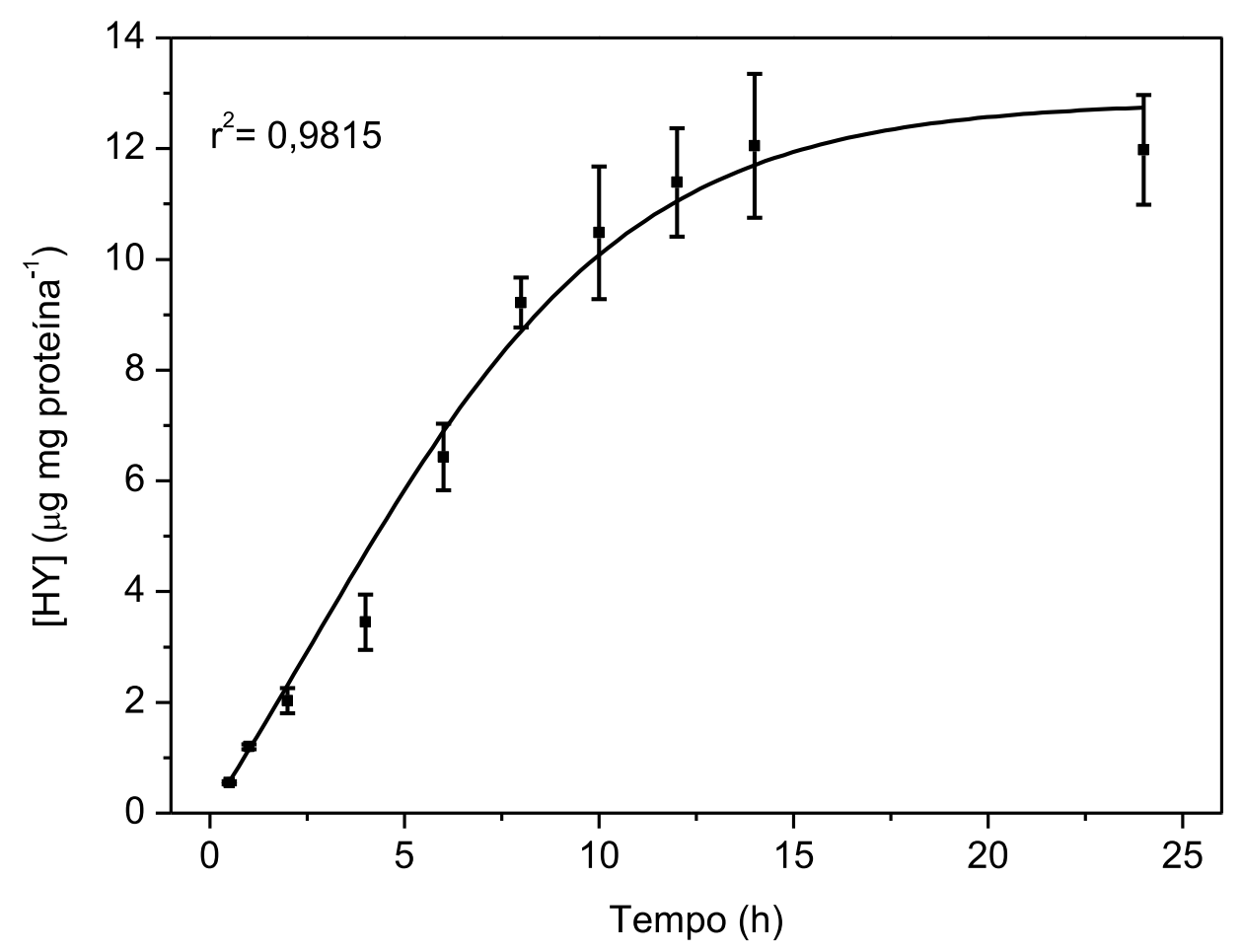

Figura 47 - Acumulação de HY em células Vero normalizada pela concentração de proteína em função do tempo de incubação. Cada ponto representa a média de cinco medidas realizadas em triplicata.

Observou-se um aumento da incorporação da HY em função do tempo de incubação até cerca de $13 \mathrm{~h}$. Após esse tempo a acumulação tende a uma saturação. A concentração de HY máxima encontrada após extração em células Vero foi inferior à obtida nas células HEp-2. Estudos da literatura relatam diferenças na acumulação da HY em células com características distintas. Kiesslich et al ${ }^{147}$ relataram acumulação específica da HY em células p388, cerca de duas vezes maior, com um tecido peritumoral. Sendo a linhagem Vero originada de tecido não 
tumoral, era esperado uma maior acumulação na linhagem HEp-2 constituída de células tumorais.

Os valores de $\mathrm{IC}_{50}\left(\mu \mathrm{g} \mathrm{mL} \mathrm{m}^{-1}\right)$ para a $\mathrm{HY}$ incubada em $2,4,8,14$ e $24 \mathrm{~h}$ com HY em células Vero e irradiadas em LED 630 nm estão apresentados na Figura 48.

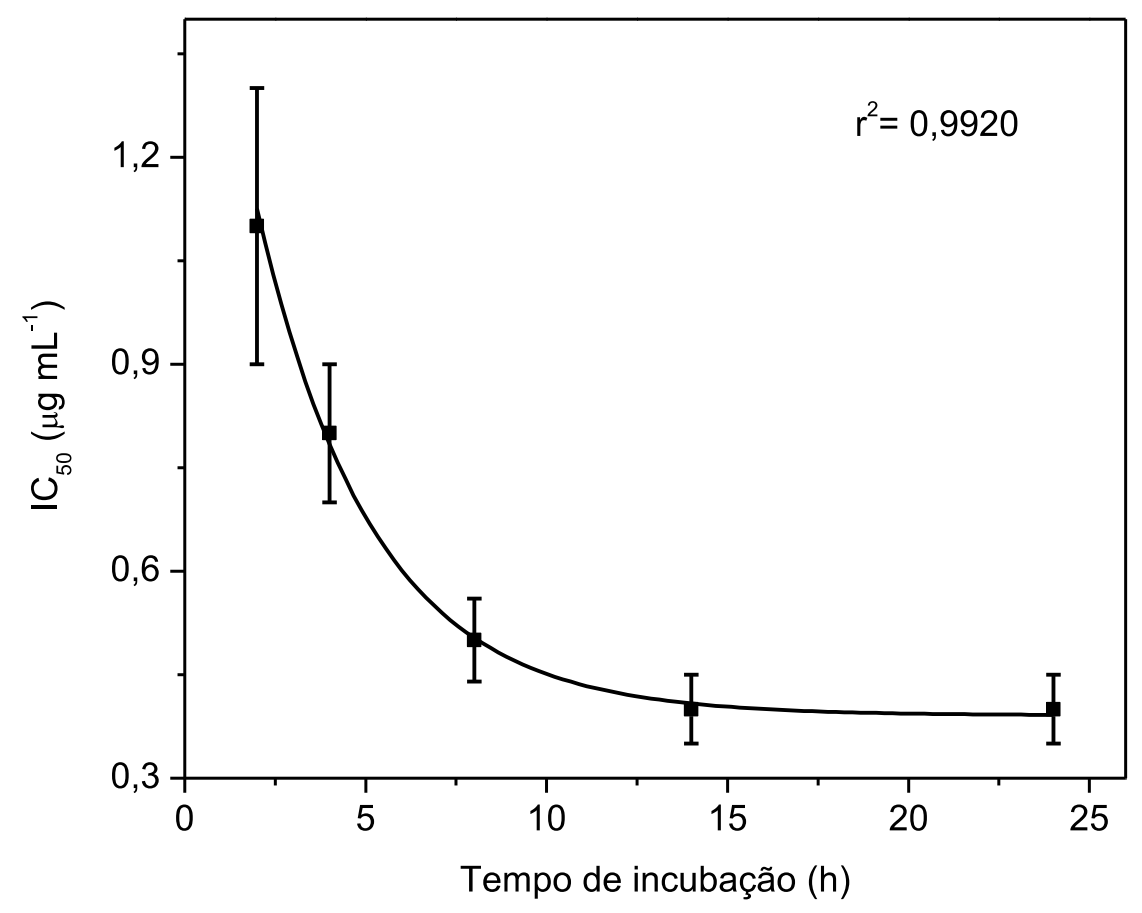

Figura 48 - IC $\mathrm{C}_{50}$ da $\mathrm{HY}$ em função do tempo de incubação, para células Vero, irradiada por 4 min, LED $\Lambda=630 \mathrm{~nm}, I=18 \mathrm{~mW} \mathrm{~cm}, \mathrm{D}=4,3 \mathrm{~J} \mathrm{~cm}^{-2}$. Cada ponto corresponde a média de três ensaios realizados em sextuplicata.

A curva acima mostra o decréscimo nos valores de $I_{50}$ até cerca de $13 \mathrm{~h}$, tempo semelhante ao obtido para as células $\mathrm{HEp}-2$. Os valores de $\mathrm{IC}_{50}$ são maiores que os encontrados para HY incubada com células HEp-2, o que se justifica, uma vez que a razão de acumulação é menor na linhagem Vero, portanto os valores de $\mathrm{IC}_{50}$ são maiores, ou seja, é preciso uma concentração maior desse fotossensibilizador para matar $50 \%$ da população celular. 
A Figura 49 apresenta os resultados de acumulação do PZ normalizada pela concentração de proteína das células Vero em função do tempo de incubação.

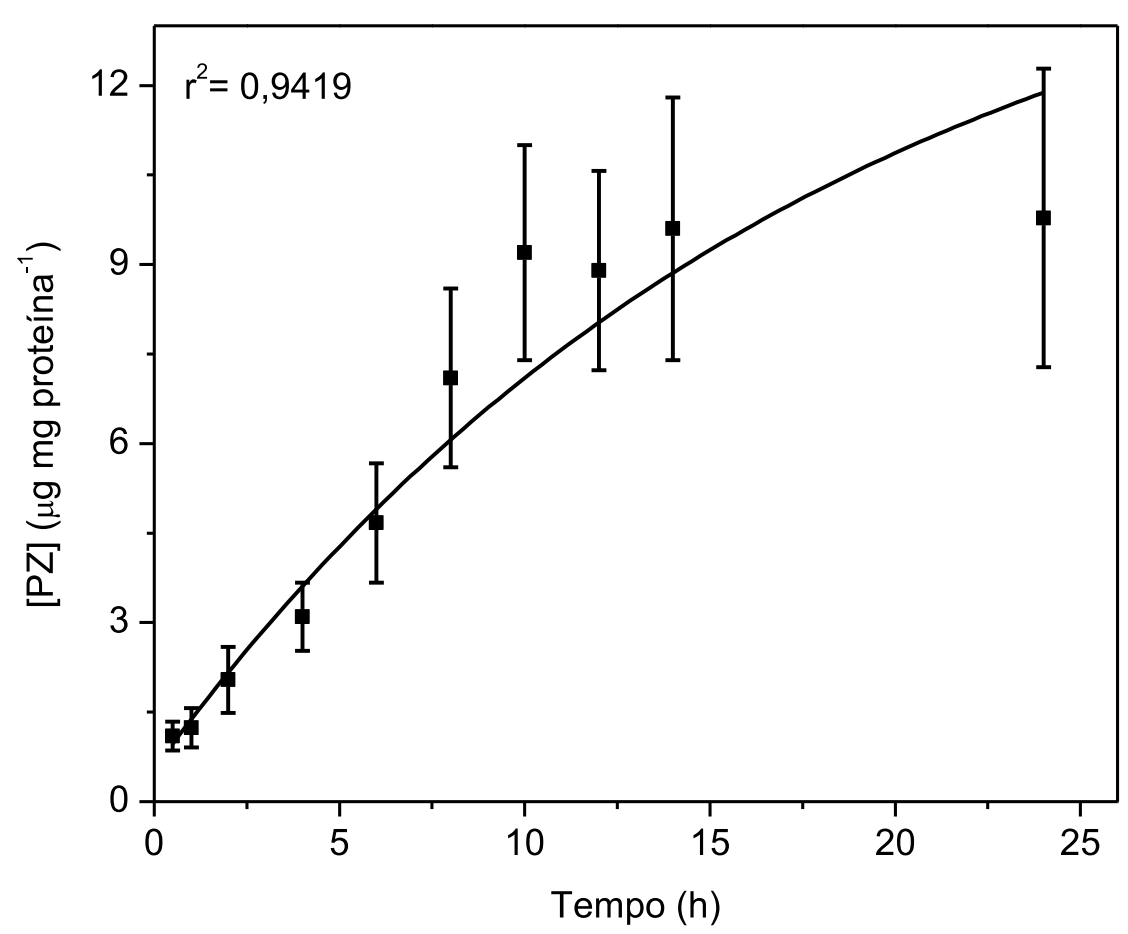

Figura 49 - Acumulação do PZ em células Vero normalizada pela concentração de proteína em função do tempo de incubação. Cada ponto representa a média de cinco medidas realizadas em triplicata.

Observou-se na figura um aumento da incorporação do PZ em função do tempo de incubação até o maior tempo estudado. Até $24 \mathrm{~h}$ a acumulação parece não ter chegado à saturação. A acumulação desse FS em células Vero também foi menor que para células HEp-2. O resultado corrobora com o obtido para a HY, mostrando claramente a maior acumulação em células tumorais.

Esses resultados são muito interessantes uma vez que em células tumorais a incorporação máxima ocorre após cerca de $15 \mathrm{~h}$ e em células normais a 
incorporação parece ser mais lenta. Esses resultados fundamentam as observações clínicas da grande seletividade do PZ para matar células malignas ${ }^{48}$.

Os experimentos para se determinar os $\mathrm{IC}_{50}$ do $\mathrm{PZ}$ em Vero obtidos após diferentes tempos de incubação e irradiação com dose de $4,3 \mathrm{~J} \mathrm{~cm}^{-2}$ estão apresentados na Figura 50.

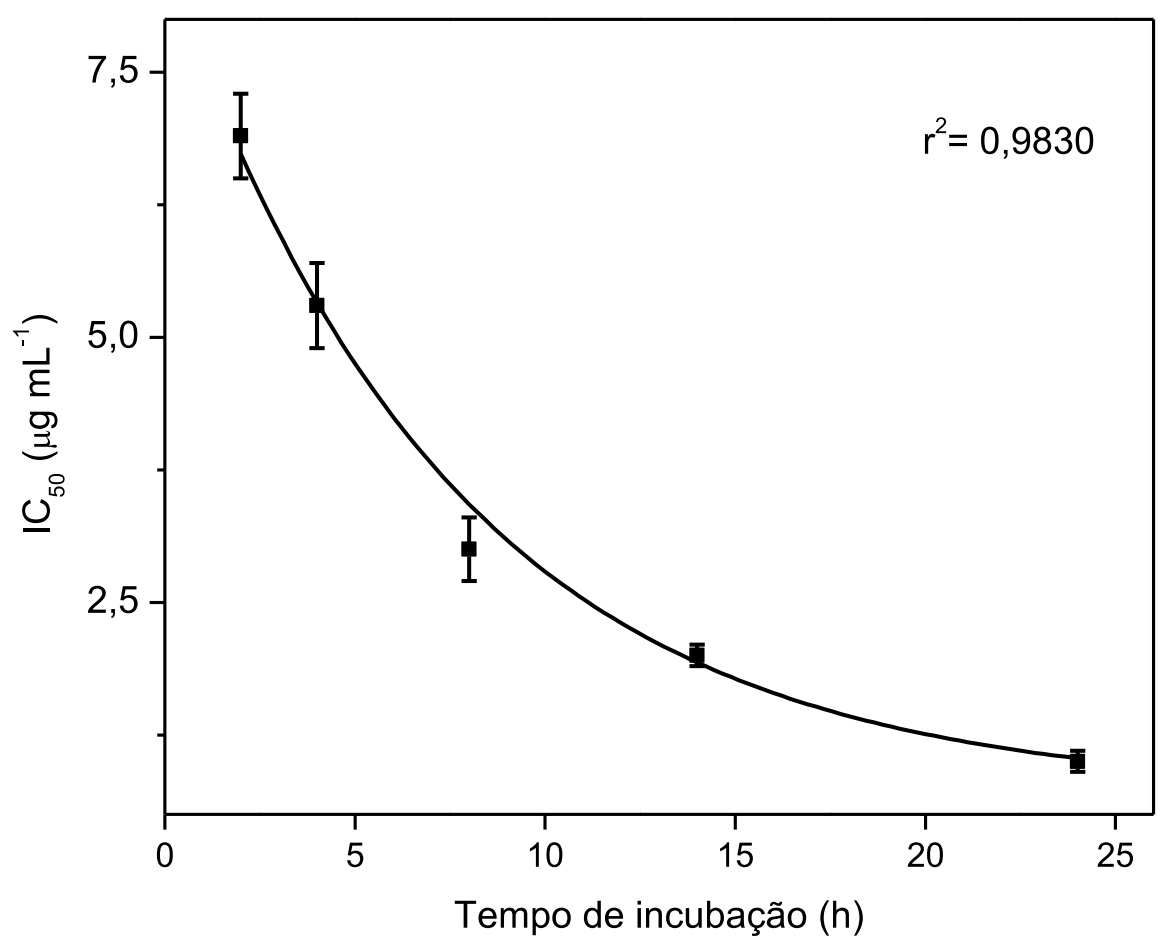

Figura 50 - $\mathrm{IC}_{50}$ do $\mathrm{PZ}$ em função do tempo de incubação, para células Vero, irradiada por 4 min, LED $\Lambda=630 \mathrm{~nm}, \mathrm{I}=18 \mathrm{~mW} \mathrm{~cm}{ }^{-2}, \mathrm{D}=4,3 \mathrm{~J} \mathrm{~cm}^{-2}$. Cada ponto corresponde a média de 3 ensaios realizados em sextuplicata.

O aumento do tempo de incubação causou a diminuição contínua nos valores de $\mathrm{IC}_{50}$, sem apresentar uma tendência de se estabilizar.

Também para o $\mathrm{PZ}$ os valores de $\mathrm{IC}_{50}$ são maiores que os encontrados para HY incubada com células HEp-2, o que pode ser explicado, uma vez que a razão de acumulação é menor na Vero, portanto os valores de $\mathrm{IC}_{50}$ são maiores. 
A acumulação em maiores quantidades na HEp-2 é um fator importante para um FS. Em geral, a seletividade do FS para se acumular mais em células tumorais é aumentada pelo caráter hidrofílico do FS ou ainda pelas propriedades anfifílicas da molécula de FS.

A Figura 51 apresenta os resultados de acumulação de PG normalizada pela concentração de proteína das células Vero em função do tempo de incubação.

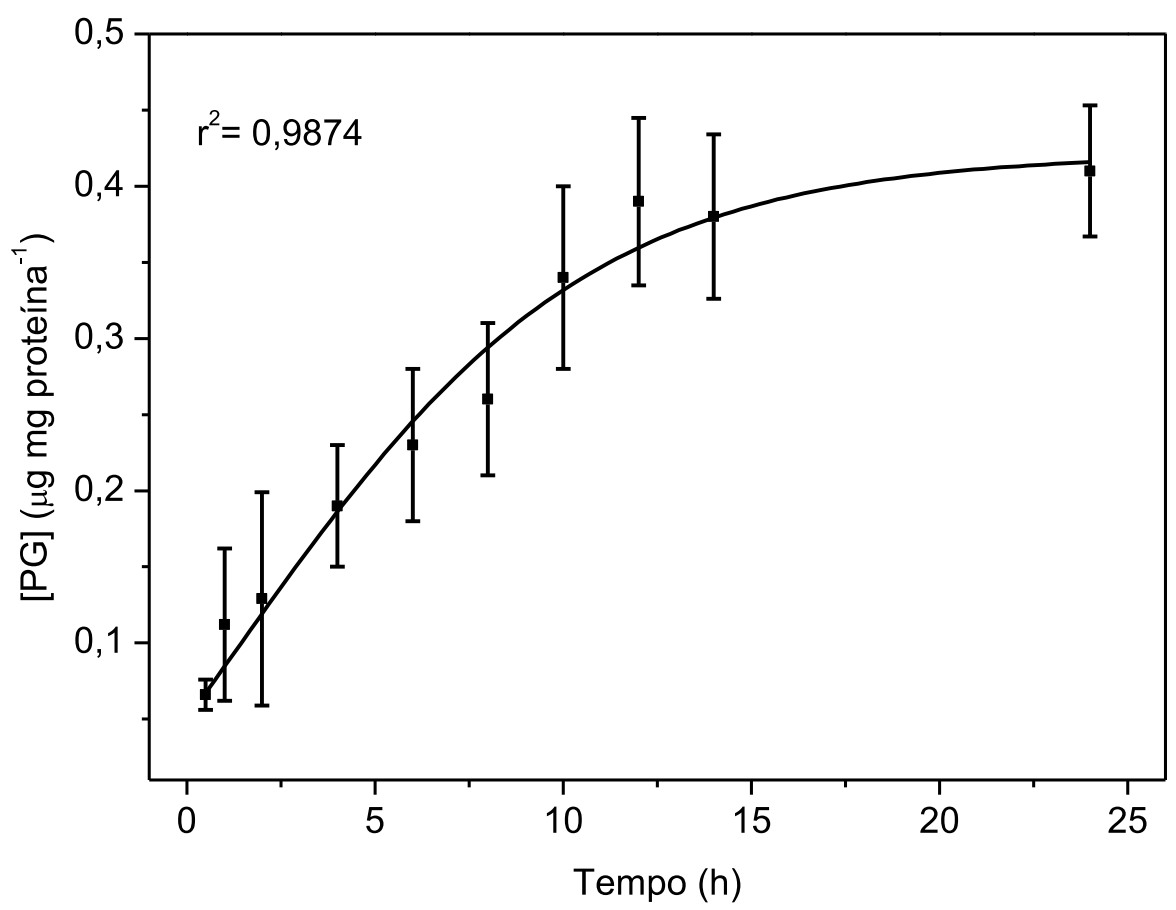

Figura 51 - Acumulação do PG em células Vero normalizada pela concentração de proteína em função do tempo de incubação. Cada ponto representa a média de cinco medidas realizadas em triplicata.

Os resultados sugerem que após cerca de $15 \mathrm{~h}$ a incorporação de PG tende a um valor constante. As concentrações de PG foram as menores encontradas nos ensaios de acumulação, o que reforça os resultados dos demais ensaios realizados nesse trabalho, indicando o Photogem como o menos efetivo dentre os três fotossensibilizadores estudados. 
A variação nos valores de $I_{50}$ para o $P G$ em células Vero estão apresentados na Figura 52.

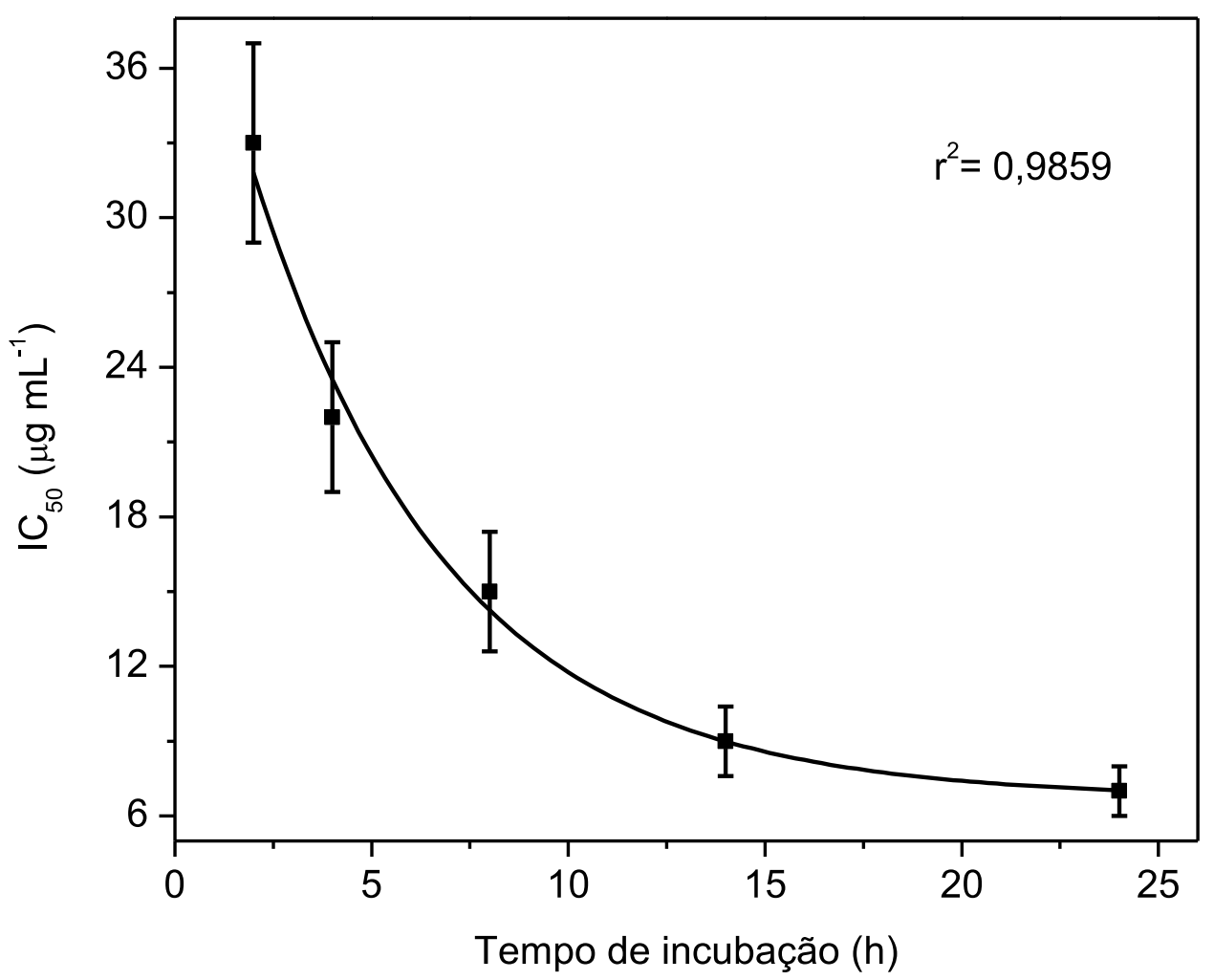

Figura $52-\mathrm{IC}_{50}$ do $P G$ em função do tempo de incubação, para células Vero, irradiada por 4 min, LED $\Lambda=630 \mathrm{~nm}, I=18 \mathrm{~mW} \mathrm{~cm}{ }^{-2}, D=4,3 \mathrm{~J} \mathrm{~cm}^{-2}$. Cada ponto corresponde a média de 3 ensaios realizados em sextuplicata.

Os valores de $\mathrm{IC}_{50}$ obtidos para o PG para células Vero foram os maiores entre todos os FSs estudados, o que está de acordo principalmente com sua baixa lipofilicidade e menor acumulação na mebrana plasmática assim como com sua atividade fotodinâmica determinada neste estudo. Após aproximadamente $15 \mathrm{~h}$ a concentração necessária para matar $50 \%$ da população celular tende a ficar constante.

Os resultados encontrados para a linhagem Vero também indicam a HY como o fotossensibilizador mais fototóxico. 
A Figura 53 compara a acumulação de HY, PZ e PG em diferentes tempos de incubação com a linhagem Vero.

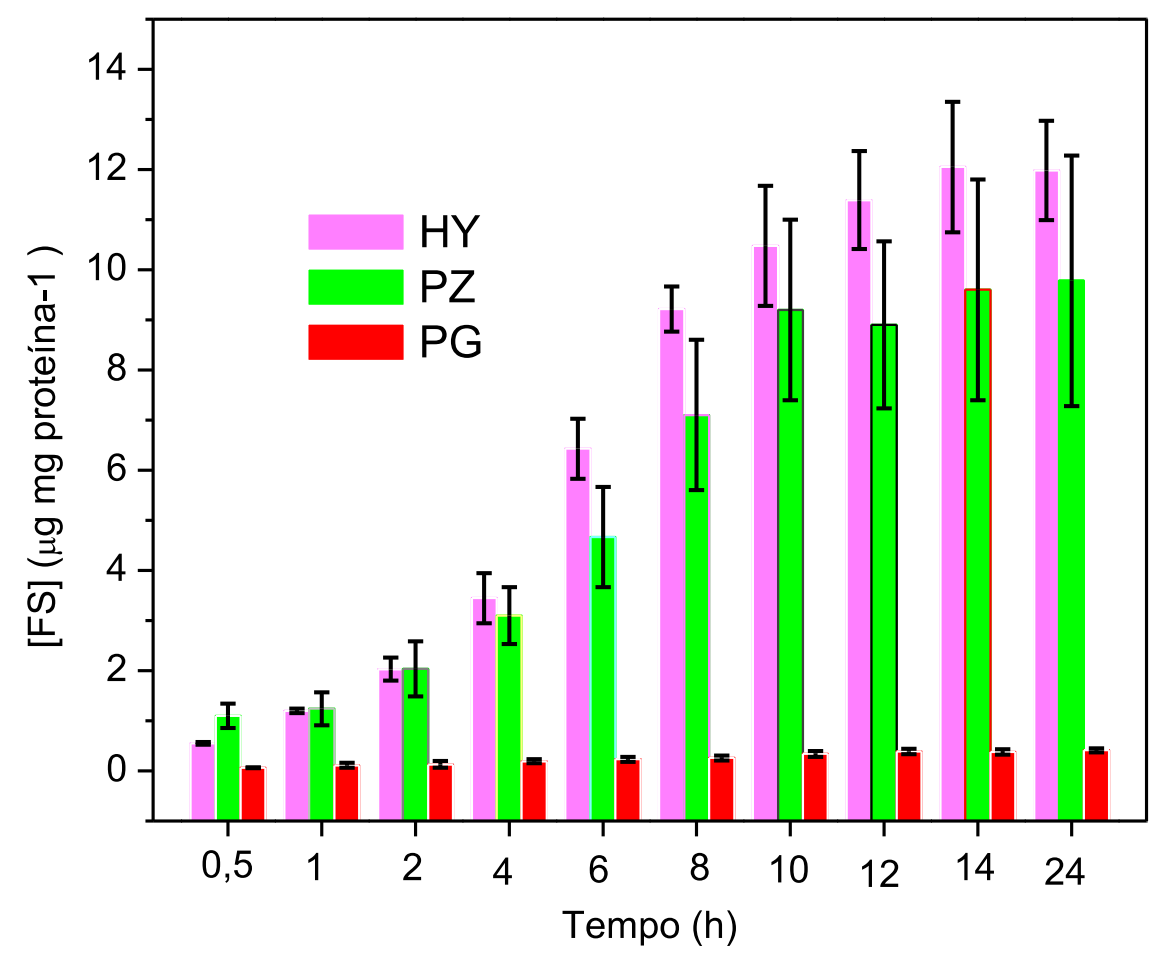

Figura 53 - Relação de concentração da Hipericina, Photodithazine e Photogem normalizada pela proteína de células Vero em função do tempo de incubação.

O resultado da comparação da quantidade de FS acumulada em células Vero é semelhante ao encontrado para a linhagem HEp-2. Evidencia-se a grande diferença na incorporação da HY e do PZ frente ao PG que apresentou os menores níveis de acumulação. Esses resultados se refletem nos valores de $\mathrm{IC}_{50}$, que são os maiores para o Photogem seguido pelo Photodithazine e menor para a Hipericina. 


\subsection{Determinação dos radicais livres por ressonância paramagnética eletrônica}

Devido à grande afinidade para reagir com radicais como $\mathrm{O}_{2}{ }^{\circ-} \mathrm{e}^{\circ} \mathrm{OH}, \mathrm{o} \mathrm{DMPO}$ foi utilizado nesses ensaios para a determinação dos radicais livres pelos FSs estudados empregando-se a técnica de RPE.

Foram realizados experimentos controle com o DMPO sem FS após irradiação e DMPO com cada um dos FSs sem irradiação para verificar o aparecimento de sinal de RPE. Em ambos os ensaios não foram observados sinais de formação de adutos.

O meio reacional apresenta papel fundamental nas reações que ocorrem após irradiação com luz, podendo levar à formação de diferentes radicais. Todos os ensaios foram realizados em condições idênticas, ou seja, nas mesmas concentrações de DMPO e de FS. Devido ao fato do Photogem ser uma mistura e sua massa molar não ser conhecida, em todos os ensaios utilizou-se a relação de massa por volume e não quantidade em mols.

A Figura 54 apresenta os espectros de RPE do aduto DMPO-OH formados após irradiação de 5 a 20 min da mistura de $200 \mu \mathrm{L}$ de Hipericina $50 \mu \mathrm{g} \mathrm{mL}^{-1}$ e $200 \mu \mathrm{L}$ de DMPO 0,5 mol L ${ }^{-1}$ com LED $630 \mathrm{~nm}$ diretamente na cavidade do RPE. 


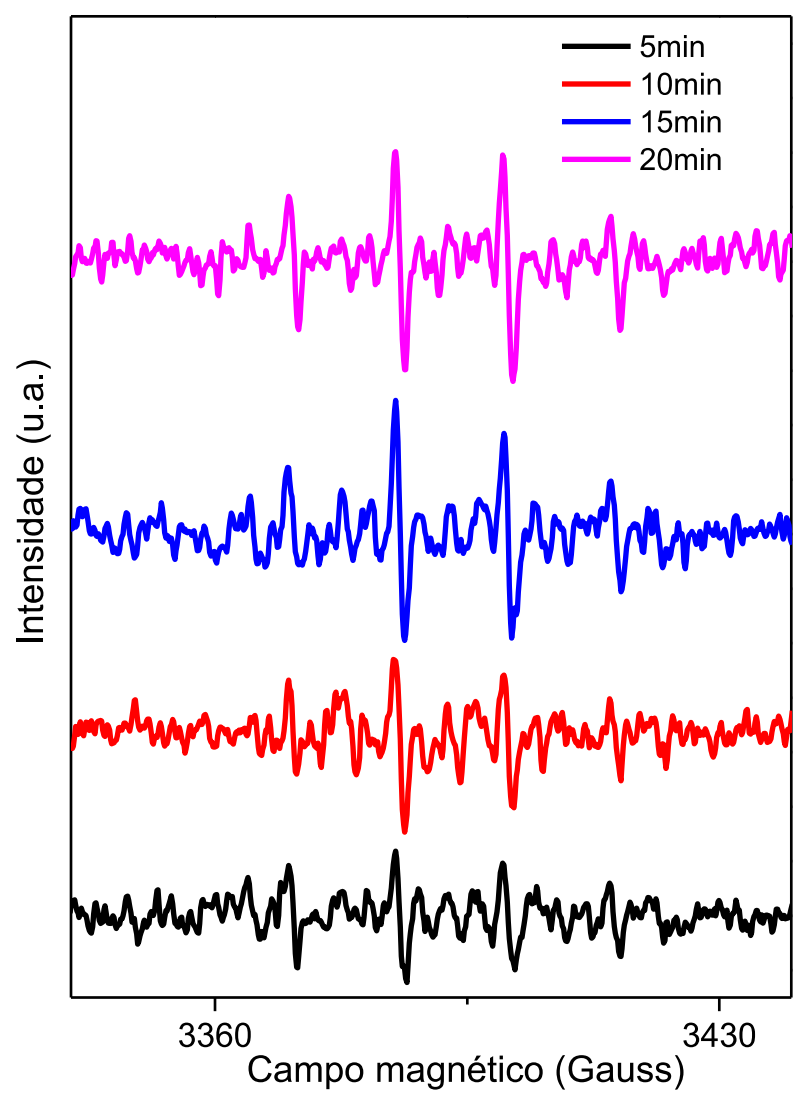

Figura 54 - Espectros de RPE do aduto DMPO-OH, formado após irradiação, em diferentes tempos da mistura HY $50 \mu \mathrm{g} \mathrm{mL}^{-1}$ e DMPO 0,5 mol L-1 em PBS (pH 7,4) com LED $630 \mathrm{~nm}$, l= $10 \mathrm{~mW} \mathrm{~cm}^{-2}$.

Após a irradiação da solução de Hipericina $\left(50 \mu \mathrm{g} \mathrm{mL}{ }^{-1}\right)$ na presença de DMPO foi observado um observado um espectro de RPE decontendo quatro linhas, podendo ser identificado apenas um aduto com constante de acoplamento hiperfina igual a $a_{N}=a_{H}{ }^{\beta}=1,45 \mathrm{mT}$ e razão de intensidade de 1:2:2:1, correspondente ao aduto DMPO-OH ${ }^{107}$. Pode-se observar que a intensidade do sinal do aduto formado aumenta em função do tempo de irradiação. Nestes experimentos o tempo de irradiação não ultrapassou $20 \mathrm{~min}$, correspondendo ao tempo de irradiação dos ensaios de fototoxicidade com as linhagens celulares HEp-2 e Vero.

Na Figura 55 está apresentada uma reação de formação do aduto DMPO$\mathrm{OH}$. 


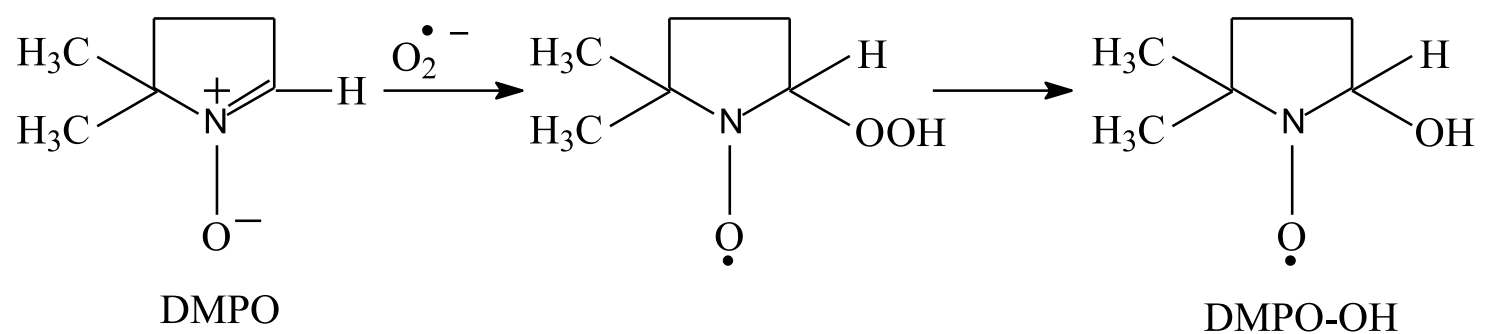

Figura 55 - Reação do DMPO com radical $\mathrm{O}_{2}{ }^{--}$formando o aduto DMPO-OH.

Primeiramente forma-se o aduto $\mathrm{DMPO}-\mathrm{O}_{2}{ }^{--}$que é muito instável e tem tempo de meia vida muito baixo (aproximadamente $60 \mathrm{~s}$ ) que se decompõe levando à formação do DMPO-OH sendo este o aduto identificado por RPE ${ }^{152}$.

Mothilal et al ${ }^{109}$ estudaram os radicais livres, por RPE, formados após fotossensibilização de uma série de derivados de antraquinona, irradiadas com lâmpada de xenônio acoplada a um filtro a fim de gerar uma janela espectral em torno de 300 a $700 \mathrm{~nm}$. Os adutos formados foram identificados como sendo DMPO-OH, portanto um resultado semelhante ao apresentado acima para Hipericina. Além da identificação desse radical o estudo acompanhou a formação dos radicais em função do tempo de irradiação (até $12 \mathrm{~min}$ ) dos derivados de antraquinona, verificando o aumento da intensidade do sinal de RPE para esse aduto para todos os derivados, encontrando apenas diferenças na intensidade do sinal para cada composto. Isso indica diferenças na geração da quantidade de radicais livres entre esses compostos.

A Figura 56 apresenta a intensidade do sinal do aduto DMPO-OH em função do tempo de irradiação da mistura HY e DMPO em 630 nm. 


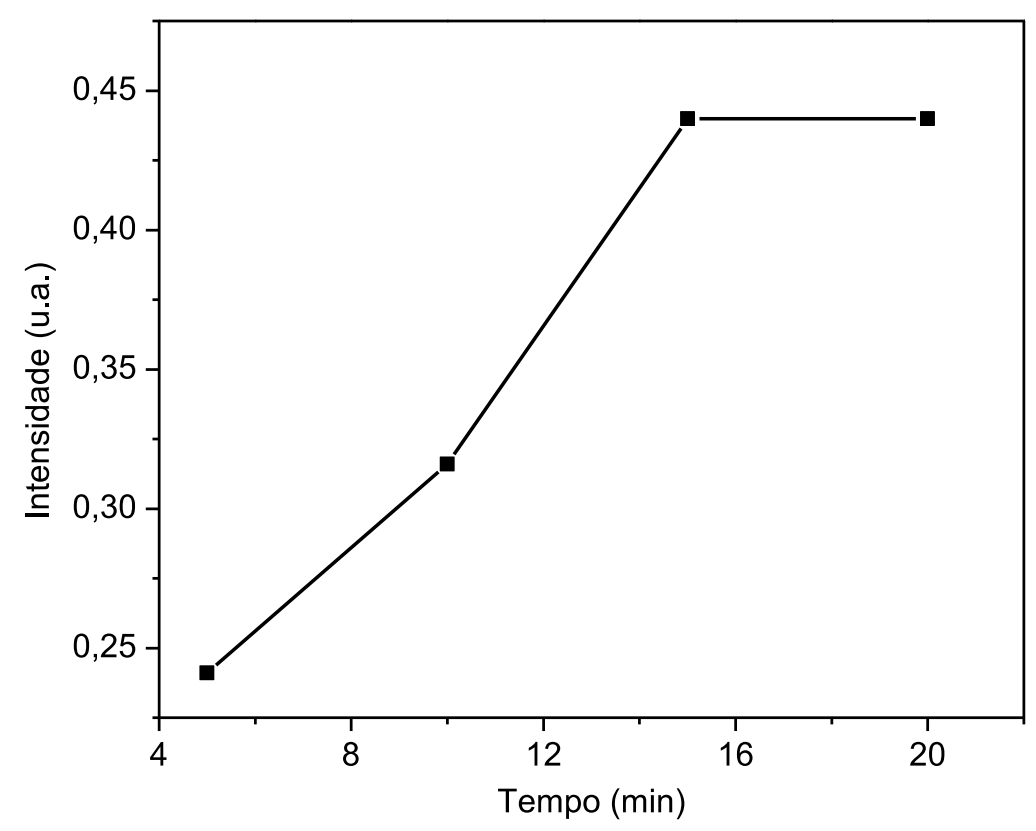

Figura 56 - Intensidade de formação de DMPO-OH, formado após irradiação com LED $630 \mathrm{~nm}$, $\mathrm{l}=10 \mathrm{~mW} \mathrm{~cm}^{-2}$ de uma mistura de HY $50 \mu \mathrm{g} \mathrm{mL}^{-1}$ e DMPO $0,5 \mathrm{~mol} \mathrm{~L}^{-1} \mathrm{em} \mathrm{PBS}(\mathrm{pH} 7,4)$, em função do tempo de irradiação.

Observa-se na Figura 57 que a intensidade do sinal do aduto DMPO-OH aumenta até 15 min de irradiação da mistura HY-DMPO, sendo que após esse tempo a intensidade do pico de RPE se estabiliza, o que pode indicar o esgotamento de geração de radicais livres pela HY. A detecção do aduto DMPO-OH evidencia que a fotossensibilização da HY ocorre também via mecanismo tipo I, além do tipo II como foi confirmado através do ensaio de oxidação do ácido úrico pelo oxigênio singlete.

A Figura 57 mostra espectros de RPE do DMPO-OH, obtidos após irradiação com LED $630 \mathrm{~nm}$ da mistura contendo PZ $50 \mu \mathrm{g} \mathrm{mL}^{-1}(200 \mu \mathrm{L})$ e DMPO 0,5 $\mathrm{mol} \mathrm{L}^{-1}$ $(200 \mu \mathrm{L})$, em função do tempo de irradiação. 


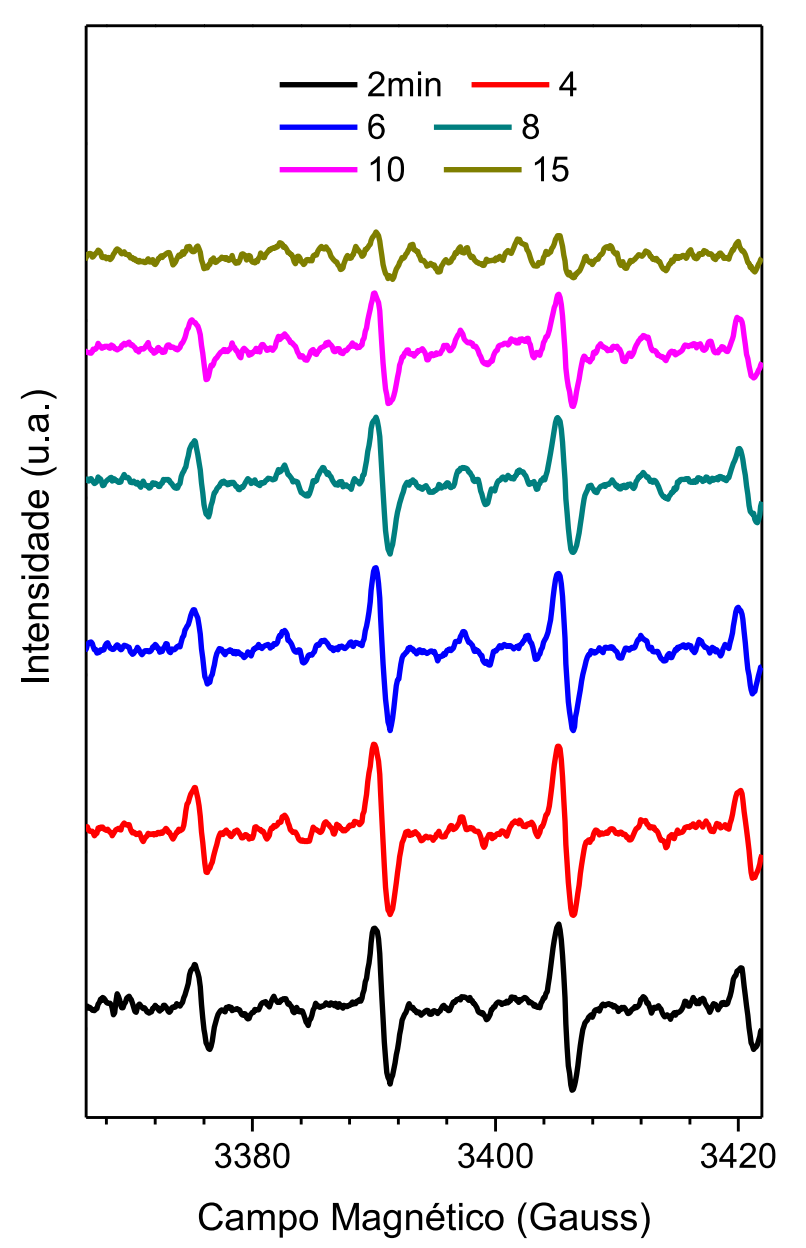

Figura 57 - Espectro de RPE do DMPO-OH, formado após irradiação com LED $\Lambda=630 \mathrm{~nm}$, $\mathrm{l}=10 \mathrm{~mW} \mathrm{~cm}^{-2}$ contendo PZ $50 \mu \mathrm{g} \mathrm{mL}^{-1}$ e DMPO $0,5 \mathrm{~mol} \mathrm{~L}^{-1}$ e PBS $(\mathrm{pH} 7,4)$, em função do tempo.

Após irradiação da solução de Photodithazine $\left(50 \mu \mathrm{g} \mathrm{mL}^{-1}\right)$ na presença de DMPO também foi observado um espectro de RPE de quatro linhas, podendo ser identificado apenas um aduto com constante de acoplamento hiperfina igual a $a_{N}=$ $a_{H}{ }^{\beta}=1,45 \mathrm{mT}$ e razão de intensidade de 1:2:2:1, correspondente ao aduto DMPO$\mathrm{OH}^{129}$. Observa-se que a intensidade do sinal do aduto formado diminui em função do tempo de irradiação. A Figura 58 apresenta o decréscimo da intensidade do aduto DMPO-OH em função do tempo de irradiação da mistura PZ com DMPO. 


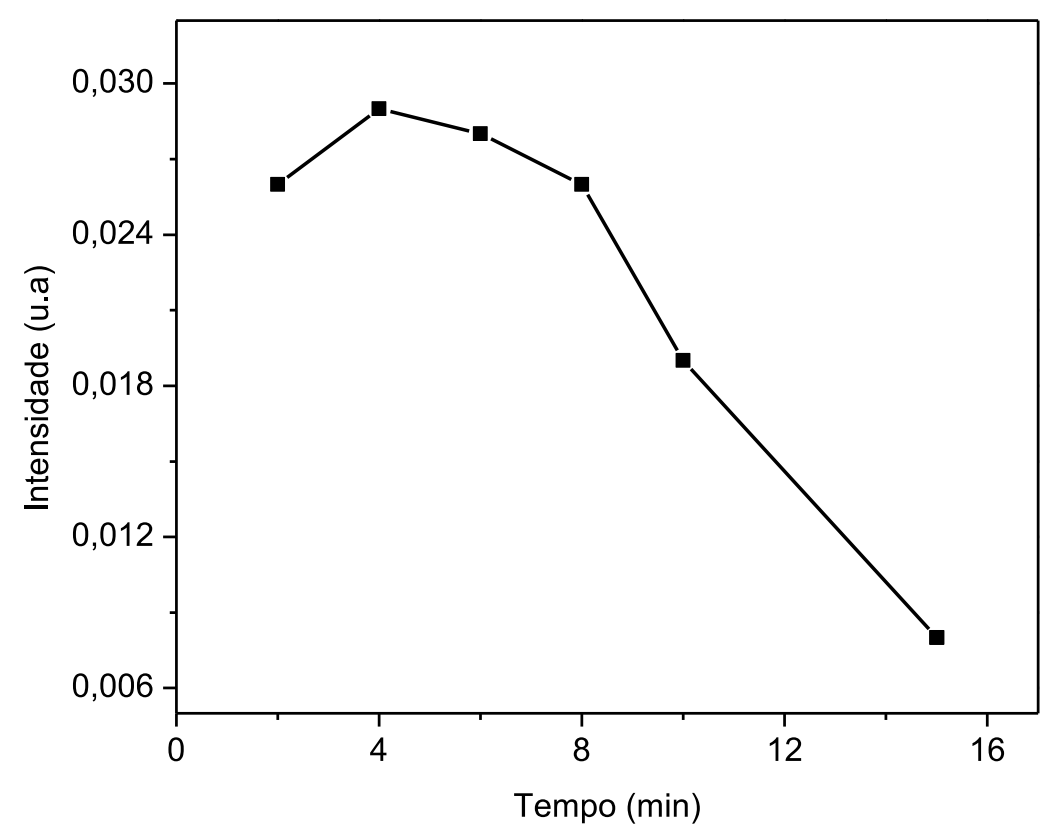

Figura 58 - Intensidade de formação de DMPO-OH, formado após irradiação com LED $630 \mathrm{~nm}$, I $=10 \mathrm{~mW} \mathrm{~cm}^{-2}$ de uma mistura de PZ $50 \mu \mathrm{g} \mathrm{mL}^{-1}$ e DMPO $0,5 \mathrm{~mol} \mathrm{~L}^{-1} \mathrm{em} \mathrm{PBS}(\mathrm{pH} 7,4)$, em função do tempo de irradiação.

Pode-se observar que no intervalo de irradiação de 2 a 4 min a intensidade do pico RPE aumentou e após esse tempo ocorreu um decréscimo bastante acentuado na intensidade, o aduto formado é estável até 4 min.

Para o Photogem espectros idênticos ao da HY e do PZ foram obtidos com quatro linhas, podendo ser identificado apenas um aduto com constante de acoplamento hiperfina igual $a a_{N}=a_{H}{ }^{\beta}=1,45 \mathrm{mT}$ e razão de intensidade de 1:2:2:1, correspondente ao aduto DMPO-OH ${ }^{129}$ (Figura 59).

Nesse caso, a detecção da intensidade do sinal ocorreu após 2 min de irradiação, na detecção seguinte após 3 min de irradiação, sofreu um decréscimo. A Figura 59 apresenta o decréscimo da intensidade do aduto DMPO-OH em função do tempo de irradiação da mistura PG e DMPO. 


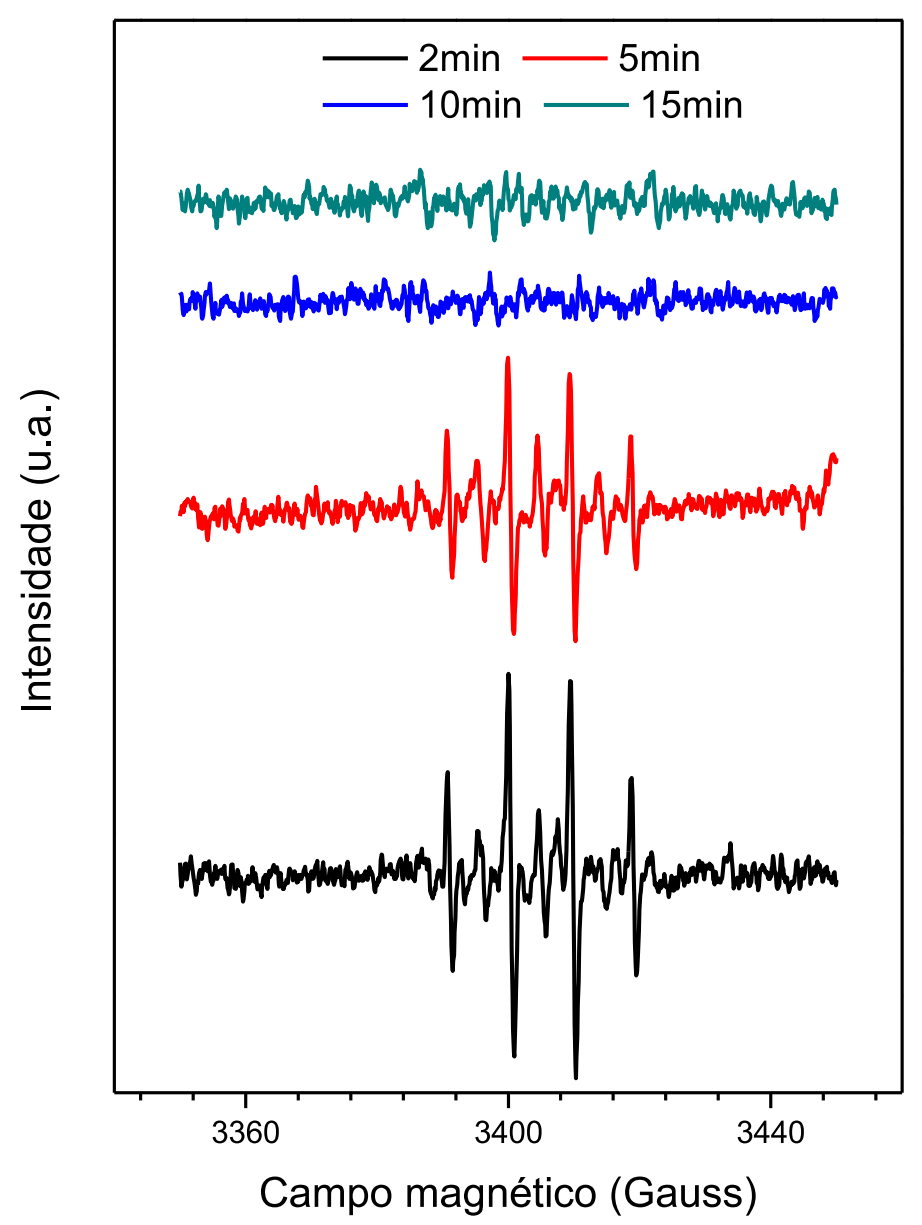

Figura 59 - Espectro de RPE do DMPO-OH, formado após irradiação com LED $630 \mathrm{~nm}$, $\mathrm{I}=10 \mathrm{~mW} \mathrm{~cm}^{-2}$ contendo PG $50 \mu \mathrm{g} \mathrm{mL}^{-1}$ e DMPO $0,5 \mathrm{~mol} \mathrm{~L}^{-1}$ em PBS (pH 7,4), em função do tempo.

Haseloff e Ebert. ${ }^{148}$ relataram a geração de radicais livres após irradiação de hematopofirina na presença de DMPO com uma lâmpada de mercúrio com dose $10 \mathrm{~mW} \mathrm{~cm}^{-2} \mathrm{~s}^{-1}$ na cavidade do RPE. Foi identificada a geração de radicais livres de superóxido que após 3 min de irradiação apresentou um rápido decréscimo da intensidade do sinal do aduto. O Photogem é um derivado de hematoporfirina e apresentou comportamento semelhante ao descrito apesar de existirem várias diferenças entre os ensaios, como solvente utilizado, concentração do FS, saturação com oxigênio ou com atmosfera inerte que podem influenciar na geração do tipo de radicais. 


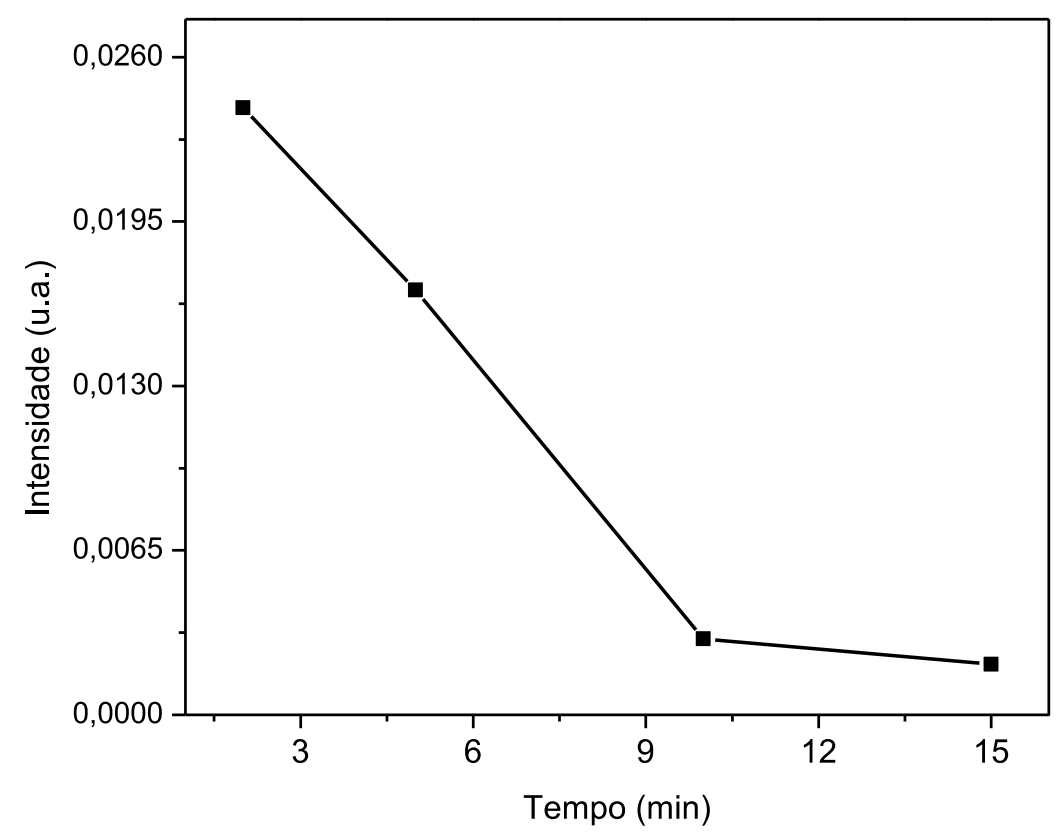

Figura 60 - Intensidade de formação de DMPO-OH, formado após irradiação com LED $630 \mathrm{~nm}$, $\mathrm{I}=10 \mathrm{~mW} \mathrm{~cm}^{-2}$ de uma mistura de PG $50 \mu \mathrm{g} \mathrm{mL}^{-1}$ e DMPO $0,5 \mathrm{~mol} \mathrm{~L}^{-1} \mathrm{em} \mathrm{PBS}(\mathrm{pH} 7,4)$, em função do tempo de irradiação.

Semelhante ao resultado encontrado para o PZ, o PG apresentou decréscimo na intensidade do RPE do aduto DMPO-OH (Figura 60). Apesar dos tempos de deteç̧ão dos adutos não serem idênticos nos dois experimentos, estão muito próximos e os dois indicam diminuição do sinal desse aduto em pouco mais de 3 min de irradiação.

Os resultados mostraram que além do mecanismo tipo II, via oxigênio singlete, ocorre o mecanismo tipo I, para os três fotossensibilizadores. A Hipericina aparece como gerador de radical livre mais estável entre os três FSs testados o que pode favorecer a sua maior atividade fotodinâmica encontrada em todos os resultados apresentados nesse estudo. 


\section{CONCLUSÕES}

Neste trabalho foram estudados três FSs: Photogem ${ }^{\circledR}$, um derivado de hematoporfirina que está sendo usado em TFD no Brasil; Photodithazine ${ }^{\circledR}$, derivado hidrossolúvel da clorina e6 e Hipericina, uma antraquinona fotossensível que foi sintetizada no Brasil.

Utilizando-se de uma série de parâmetros o presente estudo comparou esses três FSs. HY foi o FS que apresentou um valor positivo de $\log \mathrm{P}$, portanto é o $\mathrm{FS}$ de maior lipofilicidade, já o PZ e o PG podem ser considerados hidrofílicos, pois apresentaram log $\mathrm{P}$ menor que zero. Quanto maior a lipofilicidade mais rápida deve ser a sua difusão e mais FS se acumula nas células. A comparação da incorporação dos FSs em células normais e tumorais de fato mostrou que HY acumula-se mais rapidamente e em maior quantidade do que o PZ e o PG, um resultado que corrobora com a determinação da lipofilicidade. Nos estudos de determinação da concentração inibitória média $\left(I_{50}\right)$ na presença e ausência de luz em células tumorais HEp-2 e B16-F10 e em células normais Vero e McCoy em diferentes doses de luz a HY apresentou fototoxicidade muito superior aos demais FSs uma vez que os valores de $\mathrm{IC}_{50}$ obtidos foram muito menores para todas as doses testadas, além de ter a maior potencialização pela luz. Esse resultado é coerente com a alta lipofilicidade e incorporação obtida para a HY.

A HY foi o FS que apresentou a maior eficiência em fotoxidar BSA, fato que pode estar relacionado ao tempo de vida do FS no estado triplete excitado, sugerindo que a HY tem maior probabilidade de interação com o oxigênio molecular, levando a um rendimento quântico de geração de oxigênio singlete maior do que o 
$P Z$ e o PG o que resulta em uma maior eficiência fotodinâmica. A fotoxidação do ácido úrico foi acompanhada após irradiação dos FSs na presença de ácido úrico a fim de se avaliar de uma forma indireta o rendimento quântico de formação de oxigênio singlete $(\Delta \Phi)$. Também nesse caso a HY apresentou o melhor desempenho, seguida pelo PZ e PG, o que está de acordo com os resultados obtidos com BSA. Utilizando-se a rodamina B como padrão, encontrou-se que HY é o FS com maior rendimento quântico de fluorescência. Entretanto, quando esse parâmetro é comparado com o $\Phi_{\mathrm{f}}$ da rodamina para os três FSs, estes valores são extremamente pequenos, indicando que a emissão de fluorescência não é o mecanismo principal de decaimento do estado singlete. Sendo assim, deve ocorrer um cruzamento intersistema para o estado triplete, levando à formação de radicais livres de oxigênio que são altamente citotóxicos, o que é desejável para um FS efetivo na Terapia Fotodinâmica.

Além disso, foi identificado por RPE que o radical livre hidroxila é formado após irradiação dos FSs com LED vermelho. Esse tipo de radical é formado através da transferência de energia do FS quando este se encontra no estado excitado após irradiação, ou seja, pelo mecanismo tipo I. Dessa forma pode-se concluir que os ambos os mecanismos, tipo I e tipo I| estão envolvidos na formação de radicais livres que são altamente reativos levando à fotoxidação dos componentes celulares e causando o efeito citotóxico após irradiação dos três fotossensibilizadores.

Desse modo, os resultados obtidos neste trabalho sugerem que a Hipericina tem grande potencial como fotossensibilizador para utilização na Terapia Fotodinâmica. 


\section{REFERÊNCIAS BIBLIOGRÁFICAS}

1. ALMEIDA, V. L.; LEITÃO, A.; REINA, L. C. B.; MONTANARI, C. A.; DONNICI, C. L.; LOPES, M. T. P. Câncer e agentes antineoplásicos ciclo-celular específicos e ciclo-celular não específicos que interagem com o DNA: uma introdução. Química Nova, v. 28, n. 1, p. 118-129, 2005.

2. Instituto Nacional de Câncer. Disponível em: <http://www.inca.org.br>. Acesso em: 13 de julho de 2010.

3. COLUSSI, V. C. Intensificação da terapia fotodinâmica do câncer pela variação da pressão parcial do oxigênio no tecido: efeitos físicos e biológicos. 1997. 100 f. Dissertação (Doutorado em Neurociências) - Faculdade de Ciências Médicas, Departamento de Neurologia, Universidade de Campinas, Campinas, 1997.

4. FRANCO, E. L. Cancer epidemiology: substance and methods. Journal of the Brazilian Association for the Advancement of Science, v. 46, n. 1/2, 1994.

5. COOPER, G. M. The cell: a molecular approach. Massachusetts: Sinauer Associates, Inc., 1996, 673 p.

6. RUDDON, R. W. Cancer Biology. New York: Oxford University, 1995. 520 p.

7. BRYAN, G. T. Histórias Naturais dos Cânceres. Manual de oncologia clínica. Berlim: Springer-Verlag, 1999, p. 28-31

8. KUBLER, A. C. Photodynamic Therapy. Medical Laser Application, v. 20, p. 3745, 2005.

9. PAGEM, C. P.; CURTIS M. J.; SUTTER, M. C.; WALKER, M. J. A.; HOFFMAN, B. Farmacologia Integrada. São Paulo: Manole, 1999. 606 p.

10. SIMPLICIO, F. I.; MAIONCHI, F.; HIOKA, N. Terapia fotodinâmica: aspectos farmacológicos, aplicações e avanços recentes no desenvolvimento de medicamentos. Química Nova, v. 25, n. 5, p. 801-807, 2002.

11. SCHUITMAKER, J. J.; BOAS, P.; VAN LEENGOLD, H. L. L. M.; VAN DEN MEULEN, F. N.; STAR, W. M., VAN ZANDWIJK, N. Photodynamic Therapy: a promising new modality for the treatment of cancer. Journal of Photochemistry and Photobiology B-Biology, v. 34, p. 3-12, 1996.

12. ORTEL, B.; SHEA, C. R.; CALZAVARA, P. P. Molecular mechanisms of photodynamic therapy. Frontiers in Bioscience, v. 14, p. 4157-4172, 2009.

13. MOLLIE, A.; MACCORMACK, M. D. Photodynamic therapy. Advances in Dermatology. v. 22, p. 219-258, 2006. 
14. DOUGHERTY, T.J. Hematoporphyrin derivative for detection and treatment of cancer. Journal of Surgical Oncology, v. 15, n. 3, p. 209-210, 1980.

15. DOUGHERTY, T.J., et al., Photoradiation therapy for the treatment of malignant tumors. Cancer Research, v. 38, n. 8, p. 2628-2635, 1978.

16. DOUGHERTY, T. J.; Gomer, C. J.; Henderson, B. W.; Jori, G.; Kessel, D.; Korbelik, M.; Moan, J.; Peng, Q. Photodynamic therapy. Journal of the National Cancer Institute, v. 90, n. 12, p. 889-905, 1998.

17. DOUGHERTY, T.J. Photosensitization of malignant tumors. Seminars in Surgical Oncology, v. 2, n.1, p. 24-37, 1986.

18. DOUGHERTY, T.J. Photosensitizers: therapy and detection of malignant tumors. Photochemistry and Photobiology, v.45, n.6, p. 879-889, 1987.

19. PASS, H.I. Photodynamic therapy in oncology: mechanisms and clinical use. Journal of the National Cancer Institute, v. 85, n. 6, p. 443-456, 1993.

20. COLUSSI, V. C.; FEYES, D. K.; MUKHTAR, H. Perspectives of photodynamic therapy for skin diseases. Journal of Skin Pharmacology and Skin Physiology, v. 11, n. 6, p. 336-346, 1998.

21. SCHUITMAKER, J. J.; BAAS, P.; VAN LEENGOED, H. L.; VAN DER MEULEN, F. W.; STAR, W. M.; VAN ZANDWIJK, N. Photodynamic therapy: a promising new modality for the treatment of cancer. Journal of Photochemistry and Photobiology B: Biology, v. 34, n. 1, p. 3-12, 1996.

22. CASTANO, A. P.; DEMIDOVA, T. N. Mechanisms in photodynamic therapy: part one-photosensitizers, photochemistry and cellular localization. Photodiagnosis and Photodynamic Therapy, v. 1, p. 279-293, 2004.

23. LAKOWICZ, J. R. Principles of fluorescence spectroscopy, Maryland: Springer, 2006. 954 p.

24. HENDERSON, B. W.; DOUGHERTY, T. J. How does photodynamic therapy works ? Photochemistry and Photobiology, v. 55, n. 1, p. 145-157, 1992.

25. STERNBERG, E. D.; DOLPHIN, D. Porphyrin-based photosensitizers for use in photodynamic therapy. Tetrahedron, v. 54, p. 4151-4202, 1998.

26. FOOTE, C. S. Definition of Type I and Type II photosensitized oxidation. Photochemistry and Photobiology, v. 54, p. 659, 1991.

27. MACHADO, A. E. H. Terapia Fotodinâmica: princípios, potencial de aplicação e perspectivas. Química Nova, v. 23, n. 2, p. 237-243, 2000. 
28. SIBATA, C. H.; COLUSSI, V. C.; OLEINICK, N. L.; KINSELLA, T. J.

Photodynamic therapy: a new concept in medical treatment. Brazilian Journal of Medical and Bilogical Research, v. 33, p. 869-880, 2000.

29. MOAN, J.; BERG, K. The photodegradation of porphyrins in cells can be used to estimate the lifetime of singlet oxygen. Photochemistry and Photobiology, v. 53, n. 4, p. 549-553, 1991.

30. SHLIAKHTSIN, S. V.; TRUKHACHOVAA, T. V.; ISAKAUA, H. A.; ISTOMINB, Y. P. Pharmacokinetics and biodistribution of Photolon ${ }^{\circledR}$ (Fotolon $®$ ) in intact and tumor bearing rats. Photodiagnosis and Photodynamic Therapy, v. 6, p. 97-104, 2009.

31. BONNETT, R.; MARTINEZ, G. Photobleaching of sensitisers used in photodynamic therapy. Tetrahedron, v. 57, p. 9513-9547, 2001.

32. WHITE, A.; HANDLER, P.; SMITH, E. L. Principles of Biochemistry. $4^{a}$ ed. New York: Academic Press. 1968. 1187 p.

33. MIRONOV, A.F.; NIZHNIK, A.N.; NOCKEL, A.Y. Haematoporphyrin derivatives: an oligometric composition study. Journal of Photochemistry and Photobiology B: Biology, v, 4, p. 297-306, 1990.

34. MEISEL, P.; KOCHER, T. Photodynamic therapy for periodontal diseases: state of the art. Journal of Photochemistry and Photobiology B: Biology, v. 79, p. 159-170, 2005.

35. ACKROYD, R.; KEITY, C.; BROWN, N.; REED, M. The history of photodetection and photodynamic therapy. Photochemistry and Photobiology, v. 74, n. 5, p. 656-669, 2001.

36. CHATTERJEE, S. R.; SRIVASTANA, T. S.; KAMAT, J. P.; DEVASAGAYAN, T. $P$. A. Lipid peroxidation induced by a novel porphyrin plus light in isolated mitochondria: possible implications in photodynamic therapy. Molecular and Cellular Biochemistry, v. 166, p. 25-33, 1997.

37. RÚSSIA, Ministério dos serviços públicos de saúde da Federação Rússia Certificado de Registro do medicamento Photogem de n. 47. Artigo da Farmacopéia Russa, n. 42-3199-98, 10 de fevereiro de 1999, Russia, p. 1-6.

38. DOUGHERTY, T.J. Studies on the structure of porphyrins contained in Photofrin II. Photochemistry and Photobiology, v. 46, p. 569-573, 1987.

39. COLUSSI, V. C.; NICOLA, E. M. D.; NICOLA, J. H. I. Fototerapia, fotoquimioterapia e alguns fotossensibilizadores. Revista da Associação Médica Brasileira, v. 42, n. 4, p. 229-236, 1996. 
40. SOKOLOV, V. V.; STRANADKO, E. F.; ZHARKOVA, N. N.; IAKUBOVSKAIA, R. I.; FILONENKO, E. V.; ASTRAKHANKINA, T. A. The photodynamic therapy of malignant tumors in basic sites with the preparations Photohem and Photosens (the results of 3 years of observations). Vopr Onkol, v. 41, n. 2, p. 134-148, 1995.

41. CHISSOV, V. I.; SKOBELKIN, O. K.; MIRONOV, A. F.; SMIRNOV, V. V.; SOKOLOV, V. V.; SUKHIN, G. M.; FILONENKO, E. V.; LITVIN, D. G.; STRANADKO, E. F.; KOLOBANOV, A. S.; ASTRAKHANKINA, T. A.; NOKEL, A. Y.; ZHARKOVA, N. $\mathrm{N}$. Photodynamic therapy and fluorescent diagnosis of malignant tumors using preparation Photogem. Khirurgiia, n.12, p. 3-6, 1994.

42. PRIVALOV, V.A.; LAPPA, A.V.; SELIVERSTOVA, O.V.; FAIZRAKHMANOVA, A.B.; YAROVOYA, N.N.; KOCHNEVAA, E.V.; EVNEVICHB, M.V.; ANIKINAB, A.S.; RESHETNICOVC, A.V.; ZALEVSKYD, I.D. ; KEMOVC, Y.V. Clinical Trials of a New Chlorin Photosensitizer for Photodynamic Therapy of Malignant Tumors.

Proceedings of SPIE, v. 4612, p.178-189, 2002.

43. STRANADKO, E. P. H.; PONOMAREV, G. V.; MECHKOV, V. M.; RIABOV, M. V.; IVANOV, A. V.; RESHETNIKOV, A. V.; KORABOYEV, U. M. The first experience of Photodithazine clinical application for photodynamic therapy of malignant tumors. In: OPTICAL METHODS FOR TUMOR TREATMENT AND DETECTION: MECHANISMS AND TECHNIQUES IN PHOTODYNAMIC THERAPY, 9. Proceedings of SPIE, v. 3909, p. 138-144, 2000.

44. CUNDERLÍKOVÁ, B.; GANGESKAR, L.; MOAN, J. Acid-base properties of chlorin $\mathrm{e}_{6}$ : relation to cellular uptake. Journal of Photochemistry and Photobiology B: Biology. V. 53, p. 81-90, 1999.

45. CALZAVARA-PINTON, P. G.; VENTURINI, M.; SALA, R. Photodynamic therapy: update 2006 part 1: photochemistry and photobiology. Journal European Academy of Dermatology and Venereology. V. 21, p. 293-302, 2007.

46. UZDENSKY, A. B.; DERGACHEVA, O. Y.; ZHAVORONKOVA, A. A. RESHETNIKOV, A. V.; PONOMAREV, G. V. Photodynamic effect of novel chlorine $\mathrm{e}_{6}$ derivatives on a single nerve cell. Life Sciences, v. 74, p. 2185-2197, 2004.

47. BANFI, S.; CARUSO, E,; CAPRIOLI, S.; MAZZAGATTI, L.; CANTI, G.; RAVIZZA, R.; GARIBOLDI, M.; MONTI, E. Photodynamic effects of porphyrin and chlorin photosensitizers in human colon adenocarcinoma cells. Bioorganic \& Medicinal Chemistry, v. 12, p. 4853-4860, 2004.

48. RESHETNICKOV, A. V.; PONOMAREV, G. V.; ABAKUMOVA, O. Y.; TSUETKOVA, T. A.; KARMENYAN, A. V.; REBEKO, A. G.; BAUM, R. P. Novel drug form of chlorine e6. In: OPTICAL METHODS for tumor treatment and detection: mechanisms and techniques in photodynamic therapy. Proceedings of SPIE, v. 3909, p. 124-130, 2000. 
49. CIBA FOUNDATION. Photosensitizing compounds: their chemistry, biology and clinical use. Chickester: John Willey, 1989, 241 p.

50. GUEDES, R. C.; ERIKSSON, L. A. Theoretical study of hypericin. Journal of Photochemistry and Photobiology A: Chemistry, v. 172, p. 293-299, 2005.

51. KARIOTI, A.; BILIA, A. R.; Hypericins as potencial leads for new therapeutics. International Journal of Molecular Sciences, v. 11, n. 2, p. 562-594, 2010.

52. BROWN, S. B.; TRUSCOTT, T. G. New light on cancer therapy. Chemistry in Britain, v. 29, p. 955-958, 1993.

53. VANDERBOGAERDE, A. L.; CUVEELE, J. F.; PROOT, P.; HIMPENS, B. E.; MERLEVEDE, J. W; WITTE, P. A. Differential cytotoxic effects induced after photosensitization by hypericin. Journal of Photochemistry and Photobiology B: Biology, v. 38, p. 136-142, 1997.

54. AGOSTINIS, P.; VANTIEGHEM, A.; MERLEVEDE, W.; WITTE, P. A. M. Hypericin in cancer treatment: more light on the way. The International Journal of Biochemistry \& Cell Biology, v. 34, p. 221-241, 2002.

55. BLANK, M.; MANDEL, M.; HAZAN, S.; KEISARI, Y.; LAVIE, G. Anti-cancer activities of hypericin in the dark. Photochemistry and Photobilogy, v. 74, n. 2, p. 120-125, 2001.

56. FREEMAN, D.; KONSTANTINOVSKII, L.; MAZUR, Y. The structure of hypercin in solution. Searching for hypericin's 1,6 tautomer. Photochemistry and Photobiology, v. 74, n. 2, p. 206-210, 2001.

57. HADJUR, C.; RICHARD, M. J.; PARAT, M. O.; JARDON, P.; FAVIER, A. Photodynamic effects of hypericin on lipid peroxidation and antioxidant status in melanoma cells. Photochemistry and Photobiology, v. 64, n. 2, p. 375-381, 1996.

58. KAMUHABWA, A.; AGOSTINIS, P.; AHMED, B.; LANDUYT, W.; CLEYNENBREUGEL, B. V.; POPPEL, H. V.; WITTE, P. A. M. Hypericin as a potencial phototherapeutic agent in superficial transitional cell carcinoma of the bladder. Photochemistry and. Photobiology Science, v. 3, p. 772-780, 2004.

59. YAN DU, H.; OLIVO, M.; TAN, B.; BAY, B. Hypericin-mediated photodynamic therapy induces lipid peroxidation and necrosis in nasopharyngeal cancer. International Journal of Oncology, v. 23, p. 1401-1405, 2003.

60. D'HALLEWIN, M. A.; WITTE, P. A. M.; WAELKENS, E.; MERLEVEDE, W.; BAERT, L. Fluorescence detection of flat bladder carcinoma in situ after intravesical instillation of hypericin. The Journal of Urology, v. 164, p. 349-351, 2000.

61. FOX, F. E.; NIU, Z.; TOBIA, A.; ROOK, A. H. Photoactivated hypericin is an antiproliferative agent that induces a high rate of apoptotic death of normal, transformed 
and malignant T lymphocytes: implications for the treatment of cutaneous lymphoproliferative and inflammatory disorders. The Journal of Investigative Dermatology, v. 111, n. 2, p. 327-332, 1998.

62. VANDENBERGH, H. Light and porphyrins in cancer therapy. Chemistry in Britain, v. 22, n. 5, p. 430-434, 1986.

63. MACHADO, A. E. H. Terapia fotodinâmica: princípios, potencial de aplicação e perspectivas. Química Nova, v. 23, n. 2, p. 237-243, 2000.

64. PASS, H. I. Photodynamic therapy in oncology: mechanisms and clinical use. Journal of the National Cancer Institute, v. 85, n. 6, p. 443-456, 1993.

65. CIBA FOUNDATION. Photosensitizing compounds: their chemistry, biology and clinical use. Chickester: John Willey, 1989, 241 p.

66. BROWN, S. B.; TRUSCOTT, T. G. New light on cancer therapy. Chemistry in Britain, v. 29, p. 955-958, 1993.

67. DOUGHERTY, T. J.; GRINDEY, G. B.; FIEL, R.; WEISHAUPT, R.; BOYLE, D. G. Photoradiation therapy II. Cure of animal tumors with hematoporphyrin and light. Journal of the National Cancer Institute, v. 55, n. 1, p. 115-121, 1975.

68. KARU, T. J. Photobiology of low-power laser therapy. Chur, Harwood Academic, 1989, 188 p.

69. SILVESTER, J. A. Photodynamically generated bovine serum albumin radicals: evidence for damage transfer and oxidation at cysteine and tryptophan residues. Free Radical Biology \& Medicine, v. 24, n. 5, p. 754-766, 1998.

70. CARTER, D.; HO, J. X. Advances in protein chemistry. New York, Academic Press, v. 45, p. 153-203, 1994.

71. HE, X. M.; CARTER, D. Atomic-structure and chemistry of human serum albumin. Nature, v. 358, p. 209-215, 1992.

72. SINGH, T. S.; MITRA, S. Fluorimetric studies on the binding of 4-(dimethylamino) cinnamic acid with micelles and bovine serum albumin. Photochemical \& Photobiological Sciences, v. 7, p. 1063-1070, 2008.

73. GAO, D.; TIAN, Y.; LIANG, F.; JIN, D.; CHEN, Y.; ZHANG, H.; YU, A. Investigation of the $\mathrm{pH}$ dependent binding of eosin $\mathrm{Y}$ and bovine serum albumin by spectral methods. Journal of Luminescence, v. 127, p. 515-522, 2007.

74. OGUNSIPE, A.; NYOKONG, T. Photophysicochemical consequences of bovine serum albumin binding to non-transition metal phthalocyanine sulfonates.

Photochemical \& Photobiological Sciences, v. 4, p. 510-516, 2005. 
75. GAO, D.; TIAN, Y.; BI, S.; CHEN, Y.; YU, A.; ZHANG, H. Studies on the interaction of colloidal gold and serum albumins by spectral methods.

Spectrochimica Acta Part A, v. 62, p. 1203-1208, 2005.

76. BUCK, Suelen. Relação entre eficiência fotodinâmica, citoxicidade e propriedades moleculares de corantes aplicação em terapia fotodinâmica. 2009. 93 f. Dissertação (Mestrado em Química Analítica) - Instituto de Química de São Carlos, Universidade de São Paulo, São Carlos, 2009.

77. CAVALCANTE, R. S.; Avaliação da eficiência fotodinâmica de fotossensibilizadores com aplicação em terapia fotodinâmica. 2007.

Dissertação (Química Analítica São Carlos) - Universidade de São Paulo, 2007.

78. CAVALCANTE, R. S.; IMASATO, H.; PERUSSI, J. R. A combination of techniques to evaluate photodynamic efficiency of photosensitizers. Laser Physics Letters, v. 6, n. 1, p. 64- 70, 2009.

79. TAVARES, L. C. QSAR: a abordagem de Hansch. Revista Química Nova, v. 27, n. 4, p. 631-639, 2004.

80. PARKER, J. P.; STANBRO, W. D. Journal of the American Chemical Society, v. 104, p. 2067-2069, 1982.

81. FISCHER, F.; GRASCHEW, G.; SINN, H-J.; MAIER-BORST, W.; LORENZ, W. J.; SCHLAG, P. M. A chemical dosimeter for the determination of the photodynamic activity of photosensitizers. Clinica Chimica Acta, v. 274, p. 89-104, 1998.

82. NERI, C. R.; PRADO, A. P. J. M.; RIBEIRO, A. O.; SERRA, O. A.; IAMAMOTO, $Y$. Determination of the photodynamic activity of porphyrins: potential photosensitizers for treatment of age-related macular degeneration. Materials Science, v. 20, n. 2, p. 69-75, 2002.

83. BECKER, B. F. Towards the physiological function of uric acid. Free Radical Biology \& Medicine, v. 14, p. 615-631, 1993.

84. MAESTRIN, A. P. J.; RIBEIRO, A. O.; TEDESCO, A. C. A novel chlorin derivative of meso-tris(pentafluorophenyl)-4-pyridylporphyrin: synthesis, photophysics and photochemical properties. Journal of the Brazilian Chemical Society, v. 15, n. 6, p. 923-930, 2004.

85. RUBIN, M. B.; BRASLAVSKY, S. E. Quantum yield: the term and symbol. A historical search. Photochemical and Photobiological Sciences, v. 9, p. 670-674, 2010.

86. DEMAS, J. N.; CROSBY, G. A. The measurement of photoluminescence quantum yields. The Journal of Physical Chemistry, v. 75, n. 8, p. 991-1023, 1971. 
87. EATON, D. F. Reference materials for fluorescence measurement. Pure \& Applied Chemistry, v. 60, n. 7, p. 1107-1114, 1988.

88. MUROV, S. L.; CARMICHAEL, I.; HUG, G. L. Handbook of photochemistry, New York: Marcel Dekker, Inc., 1993. 420 p.

89. LI, A. P. Screening for human ADNE/Tox drug properties in drug discovery. Drug Discovery Today, v. 6, n. 7, p. 357-366, 2001.

90. SCHOONEN, W. G. E. J.; ROSS, J. A. D. M.; WESTERINK, W. M. A.; DEBITON $E$. Cytotoxic effects of 110 reference compounds on HepG2 cells and for 60 compounds on HeLa, ECC-1 and CHO cells. II Mechanistic assays on NAD(P)H, ATP and DNA contents. Toxicology in Vitro, v.19, p. 491-503, 2005.

91. CARREL, A. On the permanent life of tissues outside of the organism. The Journal of Experimental Medicine, v. 15, n. 5, p. 516-528, 1912.

92. FRESHNEY, R. I. Culture of animal cells: a manual of basic technique. New York: Wiley-Liss, 2000. 486 p.

93. SCHAEFFER, W.I. Terminology associated with cell, tissue and organ culture, molecular biology and molecular genetics. In Vitro Cell \& Developmental BiologyAnimal, v. 26, p. 97-101, 1990.

94. ALBERTS, B.; BRAY, D.; LEWIS, J.; RAFF, M.; ROBERTS, K.; WATSON, J. D. Molecular biology of the cell. New York: Garland Publishing, Inc., 1983. 1146 p.

95. CHENG, Y.; PRUSOFF, W. H. Relationship between the inhibition constant (K1) and the concentration of inhibitor which causes 50 of an enzymatic reaction.

Biochemical Pharmacology, v. 22, n. 23, p. 3099-3108.

96. MARTIN, B. M. Tissue culture techniques. Boston: Birkhauser, 1994. 247 p.

97. GANTCHEV, T. G.; OUELLET, R.; van LIER. J. E. Binding interactions and conformational changes induced by sulfonated aluminum phthalocyanines in human serum. Archives of Biochemistry and Biophysics, v. 366, p. 21-30, 1999.

98. BONNET, R. Chemical Society Reviews, v. 24, p. 19-33, 1995.

99. SONCIN, M.; FABRIS, C.; BUSETTI, A.; DEI, D.; NISTRI, D.; RONCUCCI, G.; JORI, G. Approaches to selectivity in the Zn(II)-phthalocyanine-photosensitized inactivation of wild-type and antibiotic-resistant Staphylococcus aureus.

Photochemistry and Photobilogy Sci., v. 1, p. 815-819, 2002.

100. CUNDERLÍKOVÁ, B.; GANGESKAR, L.; MOAN, J. Acid-base properties of chlorine $\mathrm{e}_{6}$ : relation to cellular uptake. Journal of Photochemistry and

Photobiology B: Biology, v. 53, p. 81-90, 1999. 
101. HALLIWELL, B.; GUTTERIDGE, J. M. C. Free Radicals in Biology and Medicine . New York: Oxford University, 1999, 936 p.

102. CHANGE, B.; SIES, H.; BOVERIS, A. Hydroperoxide metabolism in mammalian organs. Physiological Reviews, v. 59, n. 3, p. 527-605, 1979.

103. PATEL, R. P.; MCANDREW, J.; SELLAK, H.; WHITE, C. R.; JO, H.; FREEMAN, B. A.; DARLEY-USMAR, V. M. Biological aspects of reactive nitrogen species. Biochimica et Biophysica Acta, v. 1411, p. 385-400, 1984.

104. FOSTER, M. A. Magnetic Resonance in Medicine and Biology. London: Pergamon Press, 1984, 244 p.

105. BERSOHN, M.; BAIRD, J. An Introduction to electron paramagnetic resonance. New York: W. A. Benjamin, INC., 1966, 274 p.

106. FARCH, H. A.; POOLE, C. P. Low-temperature spin orientation in orientation in cobalt tutton's salt II. Physical Review B, v. 5, p. 1879-1875, 1972.

107. GOODMAN, B. A.; HALL, E. L. Electron paramagnetic spectroscopy. In: Wilson, M. J. Clay Mineralogy: Spectroscopic and Chemical Determinative Methods. London: Chapman and Hall 1994, p. 173-225.

108. ATKINS, P.; JONES, L. Princípios de Química - Questionando a vida moderna e o meio ambiente. Porto Alegre: Bookman, 2001, 914 p.

109. GANTCHEV, T. G.; URUMOV, I. J.; HUNTING, D. J.; VAN LIER, J. E. Phototoxicity and intracellular generation of free radicals by tetrasulphonated Al-and Zn-phthalocyanines. International Journal of Radiation Biology, v. 65, n. 3, p. 289-298, 1994.

110. MOTHILAL, K. K.; INBARAJ, J. J.; GANDHIDASAN, R.; MURUGESAN, R.; Photosensitization with anthraquinone derivatives: optical and EPR spin trapping studies of photogeneration of reactive oxygen species. Journal of Photochemistry and Photobiology A: Chemistry, v. 162, p. 9-16, 2004.

111. FINKELSTEIN, E.; ROSEN, G. M.; RAUCKMAN, E. J. Spin trapping of superoxide and hydroxyl radicals: pratical aspects. Archives of Biochemistry and Biophysics, v. 200, p. 1-16, 1980.

112. AMERICAN TYPE CULTURE COLLECTION: Cell lines. Disponível em: $<$ www.atcc.org> Acesso em 20 de junho 2010.

113. FRESHNEY, R. I. Culture of animal cells. New York: Wiley-Liss Inc., 1994. $486 \mathrm{p}$.

114. HARRISON, M. A.; RAE, I. F. General techniques of cell culture. New York: Cambridge University Press, 1997. 162 p. 
115. PELCZAR, JR., M. J.; CHAN, E. C. S.; KRIEG, N. R. Microbiologia conceitos e aplicações. São Paulo: Pearson Education do Brasil, 2005. 524 p.

116. BUTLER, M. Mammalian cell biotechnology a practical approach. New York: Oxford University Press, 1991. 245 p.

117. DENIZOT, F.; LANG, R. Rapid colorimetric assay for cell growth and survival. Modifications to the tetrazolium dye procedure giving improved sensitivity and reliability. Journal of Immunological Methods, v. 89, n. 2, p. 271-277, 1986.

118. CARMICHAEL, J.; DEGRAFF, W. G.; GAZDAR, A. F.; MINNA, J. D.; MITCHELL, J. B. Evaluation of a tetrazolium-based semiautomated colorimetric assay: assessment of chemosensitivity testing. Cancer Research, v. 47, n. 4, p. 936-942, 1987.

119. CHOU, T. C.; HAYBALL, M. CalcuSyn: Windows software for dose effect analysis. Cambridge: Biosoft, 1996.

120. BONNETT, R. Photosensitizers of the porphyrin and phthalocyanine series for photodynamic therapy. Chemical Society Reviews, v. 24, p. 19-33, 1995.

121. Avery, H. E. Cinética Química Básica y Mecanismos de Reaccion. Barcelona: Reverte, 1982. 190 p.

122. Formosinho, S. J. Fundamentos de Cinética Química. Lisboa: Fundação Calouste Gulbenkian, 1983. 255 p.

123. ATKINS, P. W. Physical Chemistry. New York: Oxford University Press, 1995, $545 \mathrm{p}$.

124. POOLER, J. P.; VALENZENO, D. P. Physicochemical determinants of the sensitizing effectiveness for photooxidation of nerve membranes by fluorescein derivatives. Photochemistry and Photobiology, v. 30, p. 491-498, 1979.

125. KEPCZYNSKI, M.; PANDIAN, R. P.; SMITH, K. M.; EHRENBERG, B. Do liposome-binding constants of porphyrins correlate with their measured and predicted partitioning between octanol and water? Photochemistry and Photobiology, v. 76, n. 2, p. 127-134, 2002.

126. MOREIRA, L. M.; RODRIGUES, M. R.; OLIVEIRA, H. P. M.; LIMA, A.; SOARES, R. R. S.; BATISTELA, V. R.; GEROLA, A. P.; HIOKA, N.; SEVERINO, D.; BAPTISTA, M. S.; MACHADO, A. E. H. Influência de diferentes sistemas de solvente água-etanol sobre as propriedades físico-químicas e espectroscópicas dos compostos macrocíclicos feofitina e clorina a. Química Nova, v. 33, n. 2, p. 258262, 2010. 
127. LOWRY, O. N.; ROSEBROUGH, N. J.; FARR, A. L.; RANDALL, R. J. Protein measurement with the folin phenol reagent. Journal of Biological Chemistry, v. 193, p. 265-275, 1951.

128. HUYGENS, A.; HUYGHE, D.; BORMANS, G.; VERBRUGGEN, A.; KAMUHABWA, A. R.; ROSKAMS, T.; WITTE, P. A. M. Accumulation and photocytotoxicity of hypericin and analogs in two and three dimensional cultures of transitional cell carcinoma cells. Photochemistry and Photobiology, v. 78, n. 6, p. 607-614, 2003.

129. VENKATESH, B.; MIYAZAKI, G.; IMAI, K.; MORIMOTO, H.; HORI, H. Oxygen Equilibrium and EPR Studies on $\alpha 1 \beta 1$ Hemoglobin Dimer. Journal of . Biochemistry, v. 136, p. 595-600, 2004.

130. BUETTNER, G. R. Spin trapping: ESR parameters of spin adducts. Free Radical Biology \& Medicine, v. 3, p. 259-303, 1987.

131. VIOLA, A.; HADJUR, C.; JEUNET, A.; JULLIARD, M. Electron paramagnetic resonance evidence of the generation of superoxide $\left(\mathrm{O}_{2}{ }^{--}\right)$and hydroxyl $(\cdot \mathrm{OH})$ radicals by irradiation of a new photodynamic therapy photosensitizer, Victoria Blue BO. Journal of Photochemistry and Photobiology B: Biology, v. 32, p. 49-58, 1996.

132. BARROS NETO, B.; SCARMINIO, I. S.; BRUNS, R. E. Planejamento de otimização de experimentos. Campinas: Editora da Unicamp, 1996. 299 p.

133. WYNN, J. L.; COTTON, T. M. Spectroscopic properties of hypericin in solution and surfaces. The Journal Physical Chemistry, v. 99, n. 12, p. 4317-4323, 1995.

134. YAMAZAKI, T.; NOBUHIRO, O.; YAMAZAKI, I.; SONG, P-S. Excited-state properties of hypericin: electronic spectra and fluorescence decay kinetics. The Journal Physical Chemistry, v. 97, n. 30, p. 7870-7875, 1993.

135. KALYANASUNDARAM, K. Photochemistry of polypyridine an porphyrin complexes. New York: Academic Press, 1992, 626 p.

136. RESHETNICKOV, A. V.; PONOMAREV, G. V.; ABAKUMOVA, O. Y.; TSVETKOVA, T. A.; KARMENYAN, A. V.; REBEKO, A. G.; BAUM, R. P. Novel drug form of chlorine $E_{6}$ in: optical methods for tumor treatment and detection: mechanisms and techniques in photodynamic therapy, 9. Proceedings of Spie, v. 3909 , p. 124-130, 2000.

137. MENEZES, P. F. C.; MELO, C. A. S.; BAGNATO, V. S.; IMASATO, H.; PERUSSI, J. R. Dark citotoxicity of the photoproducts of the photosensitizer photogem after photobleaching induced by laser. Laser Physics, v. 15, n. 3, p. 435442, 2005. 
138. DAZIANO, J. P.; STEENKEN, S.; CHABANNON, C. Photophysical and redox properties of a series of phthalocyanines: relation with photodynamic activities on TF-1 and Daudi leukemic cells. Photochemistry and Photobiology, v. 64, n. 4, p. 712-719, 1996.

139. CORRÊA, Juliana. Fotodegradação do Photodithazine e citotoxicidade dos fotoprodutos formados após irradiação com laser. 2006. 96 f. Dissertação (Mestrado em Química Analítica) - Instituto de Química de São Carlos, Universidade de São Paulo, São Carlos, 2006.

140. ROTOMSKIS, R.; STRECKYTE, G.; BAGDONAS, S. Phototransformations of sensitizers. 1. Significance of nature of the sensitizer in the photobleaching process and photoproduct formation in aqueous solution. Journal of Photochemistry and Photobiology B-Biology, v. 39, p. 167-171, 1997.

141. STRATIBBUJIVM, A. A.; MEEROVICH, G. A.; LOSCHENOV, V. B. Photobleaching of photosensitizers applied for photodynamic therapy. Proceedings of SPIE, v. 3909, p. 81-87, 2000.

142. MENEZES, P. F. C.; MELO, C. A. S.; BAGNATO, V. S.; IMASATO, H.; PERUSSI, J. R.; Spectroscopic studies of photobleaching and photoproduct of the photosensitizer photogem during intense illumination. Laser Physics, v. 14, n. 9, p. $1-5,2004$.

143. ALLINGER, N. L.; CAVA, M. P.; JONGH, D. C.; JOHNSON, C. R.; LEBEL, N. A.; STEVENS, C. L. Química Orgânica. Rio de Janeiro: Guanabara Koogan S. A., $1978,961 \mathrm{p}$.

144. RESNICK, R.; HALLIDAY, D. Física. São Paulo: Livros Técnicos e Científicos, 1979, $396 \mathrm{p}$.

145. CINCOTTA, L.; FOLEY, J. W.; CINCOTTA, H. Novel red absorbing benzo[a]phenoxazinium and benzo[a]phenothiazinium photosensitizers: in vitro evaluation. Photochemistry and Photobiology, v. 46, n. 5, p. 751-758, 1987.

146. LUKSIENE, Z.; WITTE, P. A. M. Hypericin-based photodynamic therapy: I. comparative antitumor activity and uptake studies in ehrlich ascite tumor. Acta Medica Lituanica, v. 9, n. 3, p. 195-199, 2002.

147. KIESSLICH, T.; KRAMMER, B.; PLAETZER, K. Cellular mechanisms and propective applications of hypericin in photodynamic therapy. Current Medicinal Chemistry, v. 13, p. 2189-2204, 2006.

148. VANDENBOGAERDE, A. L.; CUVEELE, J. F.; PROOT, P.; HIMPENS, B. E.; MERLEVEDE, W. J.; WITTE. P. A. Differencial cytotoxic effects induced after photosensitization by hypericin. Journal of Photochemistry Photobiology B: Biology, v. 38, p. 136-142, 1997. 
149. BLANK, M.; KOSTENICH, G.; LAVIE, G.; KIMEL, S.; KEISARI, Y.;

ORENSTEIN, A. Wavelength-dependent properties of photodynamic therapy using hypericin in vitro and in an animal model. Photochemistry and Photobiology, v. 76, n. 3, p. 335-340, 2002.

150. STRAIGHT, R. C.; SPIKES, J. D. Photosensitized oxidation of biomolecules. CRC Press, v. 4, p. 92-143, 1984.

151. COLASANTI, A.; KISSLINGER, A.; LIUZZI, R.; QUARTO, M.; RICCIO, P.; ROBERTI, G.; TRAMONTANO, D.; VILLANI, F. Hypericin photosensitization of tumor and metastatic cell lines of human prostate. Journal of Photochemistry and Photobiology B: Biology, v. 54, p. 103-107, 2000.

152. HASELOFF, R. F.; EBERT B. Generation of free radicals by photoexcitation of pheophorbide a, haematoporphyrin and protoporphyrin. Journal of Photochemistry and Photobiology B: Biology, v. 3, p. 593-602, 1989. 